\title{
12. PLEISTOCENE THROUGH MIOCENE CALCAREOUS NANNOFOSSILS FROM EASTERN EQUATORIAL PACIFIC OCEAN (LEG 138) ${ }^{1}$
}

\author{
Isabella Raffi ${ }^{2}$ and José-Abel Flores ${ }^{3}$
}

\begin{abstract}
The calcareous nannofossil biostratigraphy of the sediments retrieved during Leg 138 in the eastern equatorial Pacific Ocean is presented and discussed. The sedimentary sequences stidoed, at 10 of the 11 sites drilled, span the stratigraphic interval from Pleistocene to upper (Sites 847 and 848) and middle Miocene (Sites 851, 852, and 853), and three extend to the upper part of the lower Miocene (Sites 844, 845, and 846). Most of the zonal boundaries of the 1973 zonation of Bukry and standard 1971 zonation of Martini are recognized and used for the biostratigraphic classification of these low-latitude sediments. Additional biostratigraphic events are discussed and in some intervals are used as secondary criteria for improving the biostratigraphic resolution. A further subdivision of upper Miocene Subzone CN9b of Okada and Bukry (1980) is proposed using the lowest and highest occurrences of Amaurolithus amplificus.

Comments on the biochronology of calcareous nannofossils are given, with special reference to Miocene events, taking advantage of the very good magnetostratigraphy and orbitally tuned time scale produced for the Leg 138 sites.
\end{abstract}

\section{INTRODUCTION}

During Ocean Drilling Program (ODP) Leg 138, the Neogene sediments of the eastern equatorial Pacific Ocean were sampled. This leg was the fifth in a series designed to recover high-quality sedimentary sections in the tropical oceans for detailed studies of global climate change during late Cenozoic time. During previous cruises sediments were drilled in the western equatorial Pacific (Leg 130), the western tropical Indian Ocean (Leg 117), the Peru Current region (Leg 112), and the equatorial Atlantic Ocean (Leg 108). The major scientific objective of Leg 138 was to study Neogene paleoceanographic evolution in the highly productive waters of this region. Continuous sedimentary records, suitable for high-resolution paleoceanographic studies, were constructed by splicing together stratigraphic sections recovered by drilling adjacent and offset holes with the advanced hydraulic piston corer (APC) and the extended core barrel (XCB). Along two complementary north-south transects $\left(95^{\circ} \mathrm{W}\right.$ and $110^{\circ} \mathrm{W}$ ), 11 sites ( 42 holes) were drilled and more than $5500 \mathrm{~m}$ of cores was recovered (Fig. 1 and Table 1). Complete recovery of the stratigraphic section occurred at 8 of the 11 sites, and composite depth sections were constructed by using multiple measurements of sediment density (GRAPE) and other sedimentary parameters (see Hagelberg et al., in Mayer, Pisias, Janecek, et al., 1992). The sediments recovered range in age from the Miocene to Pleistocene. In six of the recovered sequences, high-quality magnetostratigraphic data were obtained (Leg 138 Init. Repts. volume; Schneider, this volume), and these provide an excellent stratigraphic framework (e.g., Site 845 ; Schneider, this volume). This allows us to calibrate several nannofossil events to the magnetic polarity time scale and provides new biochronologic data for the Miocene (Table 2).

In this study, we comment on (1) the Pleistocene-to-Miocene calcareous nannofossil biostratigraphy and biostratigraphic resolution in the eastern equatorial Pacific; (2) the biostratigraphic classifi-

' Pisias, N.G., Mayer, L.A., Janecek, T.R., Palmer-Julson, A., and van Andel, T.H. (Eds.), 1995. Proc. ODP, Sci. Results, 138: College Station, TX (Ocean Drilling Program). ${ }^{2}$ Istituto di Geologia, Università di Parma, c/o Villa Cybo, 00040 Castelgandolfo, Italy. (Current address: Università degli Studi "G. D'Annunzio," Chieti - Facoltà di Scienze Matematiche, Fisiche e Naturali, Italy.)

${ }^{3}$ Universidad de Salamanca, Departamento de Geologia, Paleontologia, 37008 Salamanca, Spain. cation and age assignment of 10 of the 11 sites drilled during Leg 138 ; and (3) some aspects of the late Neogene chronostratigraphy and calcareous nannofossil biochronology.

Details about the distribution patterns and biomagnetostratigraphy of some middle and late Miocene calcareous nannofossil index species are reported and discussed in Raffi et al. (this volume), who collected quantitative data from some of the Leg 138 sections.

\section{METHODS}

Smear slides of each sample were prepared from unprocessed material and were examined with a light microscope at $\times 1400$ magnification under cross-polarized and transmitted light. Approximately 2400 samples were examined. We examined approximately 200 fields of view in each slide, primarily those areas where the sample material had optimum density and where no appreciable piling of specimens had occurred (with an average number of 50 specimens per field). In each slide, the nannofossil assemblage was characterized, and the abundance of nannofossils was estimated in a semiquantitative fashion. To check for the presence or absence of index species in critical stratigraphic intervals, we used the quantitative counting techniques of Thierstein et al. (1977), Backman and Shackleton (1983), Rio et al. (1990a, 1990b), and Fornaciari et al. (1990). To detect index species events, we counted variable numbers of nannofossils, depending on the abundance of all nannofossils in the assemblage and on the abundance of the specific index species. For example, the presence or absence of index species belonging to discoasterids, helicoliths, sphenoliths, and ceratolithids was evaluated by counting a fixed number of forms belonging to the group (100-200 discoasterids, 100 helicoliths and sphenoliths, and $20-30$ ceratolithids).

All the biostratigraphic events (Fig. 2) reported in Tables 3-12 and Figures 3-12 have been quantitatively defined.

In the range charts that we present of selected sites, only selected samples have been plotted. Abundance and preservation have been semiquantitatively and qualitatively evaluated, respectively. The abundance code is as follows:

A (abundant) $=$ usually $>10$ specimens observed per field;

$C($ common $)=1-10$ specimens per field;

$\mathrm{F}(\mathrm{few})=1$ specimen per $1-10$ fields; and

$\mathrm{R}($ rare $)=<1$ specimen per 10 fields 
Table 1. Summary of Leg 138 sites.

\begin{tabular}{|c|c|c|c|}
\hline Site & Latitude & Longitude & $\begin{array}{c}\text { Water } \\
\text { depth } \\
\text { (m) }\end{array}$ \\
\hline 844 & $7^{\circ} 55.28 \mathrm{~N}$ & $90^{\circ} 28.85 \mathrm{~W}$ & 3425.0 \\
\hline 845 & $9^{\circ} 34.95 \mathrm{~N}$ & $94^{\circ} 35.45 \mathrm{~W}$ & 3715.9 \\
\hline 846 & $3^{\circ} 5.70 \mathrm{~N}$ & $90^{\circ} 49.08 \mathrm{~W}$ & 3295.6 \\
\hline 847 & $0^{\circ} 11.59 \mathrm{~S}$ & $95^{\circ} 19.23 \mathrm{~W}$ & 3346.0 \\
\hline 848 & $2^{\circ} 59.63 \mathrm{~S}$ & $110^{\circ} 28.79 \mathrm{~W}$ & 3867.3 \\
\hline 849 & $0^{\circ} 10.98 \mathrm{~N}$ & $110^{\circ} 31.18 \mathrm{~W}$ & 3850.8 \\
\hline 850 & $I^{\circ} 17.83 \mathrm{~N}$ & $110^{\circ} 31.29 \mathrm{~W}$ & 3797.8 \\
\hline 851 & $2^{\circ} 46.22 \mathrm{~N}$ & $110^{\circ} 34.31 \mathrm{~W}$ & 3772.0 \\
\hline 852 & $5^{\circ} 17.57 \mathrm{~N}$ & $110^{\circ} 4.58 \mathrm{~W}$ & 3871.6 \\
\hline 853 & $7^{\circ} 12.66 \mathrm{~N}$ & $109^{\circ} 45.08 \mathrm{~W}$ & 3727.2 \\
\hline
\end{tabular}

Table 2. Calcareous nannofossil events and age estimates.

\begin{tabular}{|c|c|c|c|}
\hline Event & $\begin{array}{l}\text { Zone } \\
\text { (base) }\end{array}$ & $\begin{array}{c}\text { Adopted } \\
\text { age } \\
\text { (Ma) }\end{array}$ & Reference \\
\hline B acme Emiliania huxleyi & & $0.085-0.073$ & 1 \\
\hline B Emiliania huxleyi & CNsI5 & 0.26 & I \\
\hline T Pseudoemiliania lacunosa & $\mathrm{CN} 14 \mathrm{~b}$ & 0.461 & 1 \\
\hline Reentrance medium Gephyrocapsa spp. & $\mathrm{CNI} 4 \mathrm{a}(?)$ & 1.028 & 2 \\
\hline T large Gephyrocapsa spp. & & 1.24 & 2 \\
\hline B large Gephyrocapsa spp. & & 1.457 & 2 \\
\hline T Calcidiscus macintyrei & & 1.597 & 2 \\
\hline B medium Gephyrocapsa spp. & $\mathrm{CNI} 3 \mathrm{~b}(?)$ & 1.67 & 2 \\
\hline T Discoaster brouweri & $\mathrm{CN} 13 \mathrm{a}$ & $1.96-0.11$ & 3 \\
\hline T Discoaster pentaradiatus & $\mathrm{CN} / 2 \mathrm{~d}$ & $2.44-0.06$ & 3 \\
\hline T Discoaster surculus & $\mathrm{CN} 12 \mathrm{c}$ & $2.61-0.09$ & 3 \\
\hline T Discoaster tamalis & $\mathrm{CN} / 2 \mathrm{~b}$ & $2.76-0.01$ & 3 \\
\hline T Sphenolithus spp. & $\mathrm{CN} 12 \mathrm{aB}$ & $3.65-0.05$ & 3 \\
\hline T Reticulofenestra pseudoumbilicus & $\mathrm{CN} 12 \mathrm{aA}$ & $3.804-0.003$ & 3 \\
\hline B Ceratolithus rugosus & $\mathrm{CNIOC}$ & $5.04-0.03$ & 3 \\
\hline B Ceratolithus acutus & CNIOb & $5.34-0.02$ & 3 \\
\hline T Triquetrorhabdulus rugosus & & $5.34-0.02$ & 3 \\
\hline T Discoaster quinqueramus & CNIOa & $5.56-0.04$ & 3 \\
\hline T Amaurolithus amplificus & $\mathrm{CN} 9 \mathrm{bC}$ & $5.88-0.02$ & 3 \\
\hline B Amaurolithus amplificus & $\mathrm{CN} 9 \mathrm{bB}$ & $6.50-0.06$ & 3 \\
\hline T absence interval $R$. pseudoumbilicus & & $6.80-0.2$ & 3 \\
\hline B Amaurolithus primus & CN9bA & $7.24-0.12$ & 3 \\
\hline B Discoaster berggrenii & $\mathrm{CN} 9 \mathrm{a}$ & $8.35-0.11$ & 3 \\
\hline B Discoaster loeblichii & $\mathrm{CN} 8 \mathrm{~b}$ & $8.43-0.08$ & 3 \\
\hline B absence interval $R$. pseudoumbilicus & & $8.85-0.3$ & 3 \\
\hline B Minylitha convallis & & $9.43-0.04$ & 3 \\
\hline T Discoaster hamatus & CN8a & $9.36-0.12$ & 3 \\
\hline B Discoaster neohamatus & & $9.56-0.11$ & 3 \\
\hline B Discoaster hamatus & $\mathrm{CN} 7$ & $10.39-0.12$ & 3 \\
\hline T Coccolithus miopelagicus & & $10.39-0.1$ & 3 \\
\hline B Catinaster coalitus & CN6 & $10.71-0.01$ & 3 \\
\hline T c Discoaster kugleri & & $11.34-0.03$ & 3 \\
\hline B c Discoaster kugleri & & $11.74-0.04$ & 3 \\
\hline B Discoaster kugleri & CN5b & $12.20-0.2$ & 3 \\
\hline T Coronocyclus nitescens & & $12.12-0.01$ & 3 \\
\hline T Calcidiscus macintyrei & & $12.34-0.01$ & 3 \\
\hline T Calcidiscus premacintyrei & & $12.65-0.02$ & 3 \\
\hline B Triquetrorhabdulus rugosus & & $12.62-0.02$ & 3 \\
\hline T Discoaster signus & & $12.73-0.01$ & 3 \\
\hline T Cyclicargolithus floridanus & & $13.19-0.01$ & 3 \\
\hline T Sphenolithus heteromorphus & CN5a & $13.57-0.05$ & 3 \\
\hline T Helicosphaera ampliaperta & $\mathrm{CN} 4$ & 15.83 & 4 \\
\hline B Discoaster signus & & $16.19-0.01$ & 3 \\
\hline End acme Discoaster deflandrei & & $16.21-0.01$ & 3 \\
\hline
\end{tabular}

Notes: $\mathrm{T}=$ top occurrence, $\mathrm{B}=$ bottom occurrence, $\mathrm{T} \mathrm{c}=$ top occurrence of common and continuous species, and $\mathrm{B} \mathrm{c}=$ bottom occurrence of common and continuous species. References are as follows: $1=$ Thierstein et al. (1977), 2 = Raffi et al. (1993), $3=$ this study, and Shackleton et al. (this volume), and $4=$ reestimated from Backman et al. (1990).

The qualitative evaluation of the state of preservation of the calcareous nannofossils found within each sample was made with the following criteria:

$\mathrm{G}($ good $)=$ specimens exhibit little or no dissolution and/or overgrowth;

M-G (moderate to good $)=$ specimens exhibit slight to moderate dissolution and/or overgrowth, and the identification of some species is hampered;

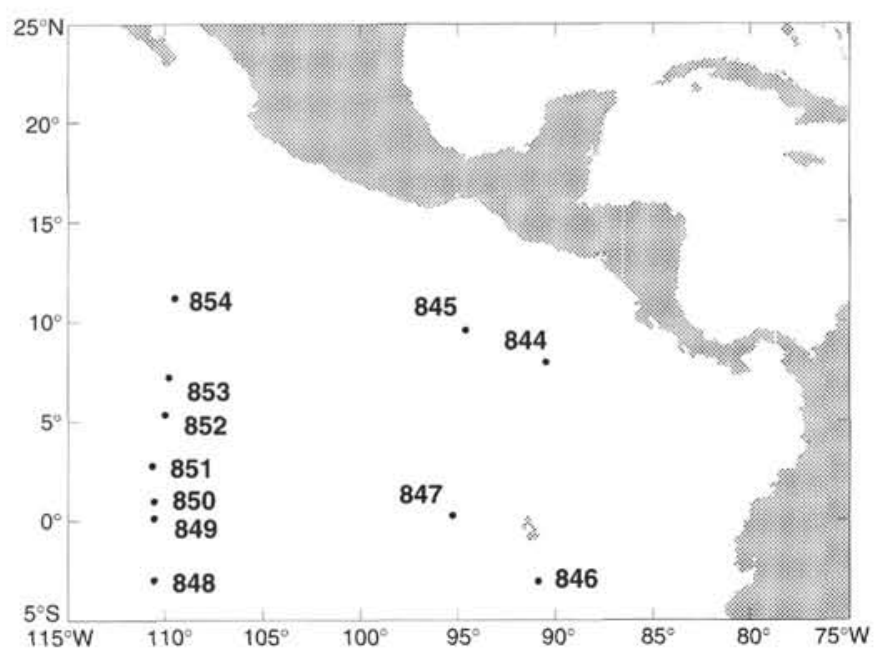

Figure 1. Location map for Leg 138 sites.

$\mathrm{M}($ moderate $)=$ specimens exhibit moderate dissolution and/or overgrowth, and identification is difficult at the specific level; and

$\mathrm{P}($ poor $)=$ specimens exhibit extreme dissolution and/or overgrowth.

These categories were determined on the basis of the "average" state of preservation of the calcareous nannofossils examined on the smear slides. Considerable variation in the state of preservation of the individual specimens can be observed in the same sample.

In the range charts, the degree of etching (E) and overgrowth (O) is also reported, following the criteria proposed by Roth and Thierstein (1972) and modified by Roth (1983), as follows:

$\mathrm{E}=0$ and $\mathrm{O}=0$ : no sign of dissolution and overgrowth;

$\mathrm{E}=1$ and $\mathrm{O}=1$ : slight dissolution and overgrowth;

$\mathrm{E}=2$ and $\mathrm{O}=2$ : moderate dissolution and overgrowth; and

$\mathrm{E}=3$ and $\mathrm{O}=3$ : severe effects of dissolution and overgrowth.

The taxa we consider here are reported in alphabetic order and by generic epithets in Appendix A. Bibliographic references for these species are given in Loeblich and Tappan (1966, 1968, 1969, 1970a, 1970b, 1971, 1973) and Aubry (1984, 1988, 1989, 1990). The taxonomic concepts we used in this study primarily followed those of Rio et al. (1990a) and are summarized below (see "Taxonomic Notes" section, this chapter).

\section{BIOSTRATIGRAPHY}

Here, we give a general discussion on the biostratigraphy obtained in the sedimentary sequences recovered during Leg 138 . We refer to the zonal schemes of Martini (1971) and Bukry (1973, 1978), which were code numbered by Okada and Bukry (1980) and are regarded as the "standard" for the biostratigraphic classification of Cenozoic marine sediments. These zonations have been applied to all the stratigraphic intervals with relative ease. In addition to the known zonal boundaries in the Pleistocene and upper Miocene, we record other bioevents that improve the biostratigraphic resolution of the two standard zonations. In Figure 2, we report the recognized nannofossil events, the zones, and the adopted definitions, together with the adopted biochronology and chronostratigraphy. Details on the biostratigraphic results of each section are reported in the individual site chapters below.

\section{Pleistocene}

The Pleistocene biostratigraphic classification is based on the biozonation of Gartner (1977) and on recent data from a biochronologic study of low- and mid-latitude, deep-sea records (Raffi et al., 1993). 
Table 3. Position of calcareous nannofossil events at Site 844 .

\begin{tabular}{|c|c|c|c|c|}
\hline Event & $\begin{array}{c}\text { Interval } \\
(\mathrm{cm})\end{array}$ & $\begin{array}{l}\text { Depth } \\
\text { (mcd) }\end{array}$ & $\begin{array}{c}\text { Interval } \\
(\mathrm{cm})\end{array}$ & $\begin{array}{l}\text { Depth } \\
\text { (mcd) }\end{array}$ \\
\hline T Pseudoemiliania lacunosa & $844 \mathrm{~B}-1 \mathrm{H}-\mathrm{CC} / 2 \mathrm{H}-\mathrm{I}, 120$ & $4.53-6.83$ & & \\
\hline Reentrance medium Gephyrocapsa spp. & $844 \mathrm{~B}-2 \mathrm{H}-4,120 / 2 \mathrm{H}-5,120$ & $11.13-12.63$ & & \\
\hline T large Gephyrocapsa spp. & $844 \mathrm{~B}-2 \mathrm{H}-5,120 / 2 \mathrm{H}-6,120$ & $12.63-14.13$ & & \\
\hline B large Gephyrocapsa spp. & $844 \mathrm{~B}-2 \mathrm{H}-7,47 / 2 \mathrm{H}-\mathrm{CC}$ & $14.90-15.61$ & & \\
\hline T Calcidiscus macintyrei & $844 \mathrm{~B}-2 \mathrm{H}-\mathrm{CC} / 3 \mathrm{H}-1,120$ & $15.61-17.45$ & & \\
\hline B medium Gephyrocapsa spp. & $844 \mathrm{~B}-3 \mathrm{H}-2,60 / 3 \mathrm{H}-2,120$ & $18.35-18.95$ & & \\
\hline T Discoaster brouweri & $844 \mathrm{~B}-3 \mathrm{H}-3,85 / 3 \mathrm{H}-3,120$ & $20.10-20.45$ & & \\
\hline T Discoaster pentaradiatus & $844 \mathrm{C}-3 \mathrm{H}-1,83 / 3 \mathrm{H}-2,83$ & $21.78-23.28$ & & \\
\hline T Discoaster surculus & $844 \mathrm{C}-3 \mathrm{H}-2,83 / 3 \mathrm{H}-3,83$ & $23.28-24.78$ & & \\
\hline B Ceratolithus acutus & $844 \mathrm{C}-4 \mathrm{H}-1,30 / 4 \mathrm{H}-1,50$ & $32.55-32.75$ & $844 \mathrm{D}-1 \mathrm{H}-3,75 / 1 \mathrm{H}-3,100$ & $32.45-32.70$ \\
\hline T Discoaster quinqueramus & $844 \mathrm{C}-4 \mathrm{H}-1,75 / 4 \mathrm{H}-1,100$ & $33.00-33.25$ & $844 \mathrm{D}-1 \mathrm{H}-3,125 / 1 \mathrm{H}-3,150$ & $32.95-33.20$ \\
\hline T Amaurolithus amplificus & $844 \mathrm{C}-4 \mathrm{H}-2,125 / 4 \mathrm{H}-2,145$ & $35.00-35.20$ & & \\
\hline B Amaurolithus amplificus & $844 \mathrm{~B}-5 \mathrm{H}-2,60 / 5 \mathrm{H}-2,90$ & $39.04-39.34$ & & \\
\hline T absence interval $R$. pseudoumbilicus & $844 \mathrm{~B}-5 \mathrm{H}-3,90 / 5 \mathrm{H}-3,120$ & $40.84-41.14$ & & \\
\hline B Amaurolithus primus & $844 \mathrm{~B}-5 \mathrm{H}-4,120 / 5 \mathrm{H}-5,29$ & $42.35-42.94$ & & \\
\hline T Minylitha convallis & $844 \mathrm{C}-5 \mathrm{H}-3,2 / 5 \mathrm{H}-3,50$ & $45.87-46.35$ & & \\
\hline B Discoaster berggrenii & $844 \mathrm{~B}-6 \mathrm{H}-4,60 / 6 \mathrm{H}-4,150$ & $51.70-52.60$ & $844 \mathrm{C}-5 \mathrm{H}-7,30 / 6 \mathrm{H}-1,70$ & $52.15-54.45$ \\
\hline B Discoaster pentaradiatus & $844 \mathrm{~B}-6 \mathrm{H}-4,150 / 6 \mathrm{H}-5,60$ & $52.60-53.20$ & & \\
\hline B Discoaster loeblichii & $844 \mathrm{~B}-6 \mathrm{H}-5,60 / 6 \mathrm{H}-6,60$ & $53.20-54.70$ & & \\
\hline B absence interval $R$. psendoumbilicus & $844 \mathrm{C}-6 \mathrm{H}-2,70 / 6 \mathrm{H}-2,90$ & $55.95-56.15$ & & \\
\hline B Minylitha convallis & $844 \mathrm{C}-6 \mathrm{H}-5,5 / 6 \mathrm{H}-5,30$ & $59.80-60.05$ & & \\
\hline T Discoaster hamatus & $844 \mathrm{~B}-7 \mathrm{H}-1,100 / 7 \mathrm{H}-1,120$ & $59.90-60.10$ & $844 \mathrm{C}-6 \mathrm{H}-5,5 / 6 \mathrm{H}-5,30$ & $59.80-60.05$ \\
\hline B Discoaster hamatus & $844 \mathrm{~B}-8 \mathrm{H}-1,60 / 8 \mathrm{H}-2,60$ & $69.26-70.76$ & $844 \mathrm{C}-7 \mathrm{H}-5,2 / 7 \mathrm{H}-5,25$ & $70.27-70.50$ \\
\hline T Coccolithus miopelagicus & $844 \mathrm{~B}-8 \mathrm{H}-2,60 / 8 \mathrm{H}-3,60$ & $70.76-72.26$ & $844 \mathrm{C}-7 \mathrm{H}-5,125 / 7 \mathrm{H}-6,2$ & $71.50-71.77$ \\
\hline B Catinaster coalitus & $844 \mathrm{~B}-8 \mathrm{H}-4,120 / 8 \mathrm{H}-5,60$ & $74.36-75.26$ & & \\
\hline T c Discoaster kugleri & $844 \mathrm{~B}-10 \mathrm{H}-1,60 / 10 \mathrm{H}-2,60$ & $91.73-93.23$ & & \\
\hline B c Discoaster kugleri & $844 \mathrm{~B}-11 \mathrm{H}-4,60 / 11 \mathrm{H}-4,120$ & $108.60-109.20$ & & \\
\hline B Discoaster kugleri & $844 \mathrm{~B}-13 \mathrm{H}-4,60 / 13 \mathrm{H}-4,120$ & $127.90-128.50$ & & \\
\hline T Coronocyclus nitescens & $844 \mathrm{~B}-13 \mathrm{H}-4,120 / 13 \mathrm{H}-5,60$ & $128.50-129.40$ & & \\
\hline T Calcidiscus premacintyrei & $844 \mathrm{~B}-14 \mathrm{H}-5,120 / 14 \mathrm{H}-6,120$ & $140.53-142.03$ & & \\
\hline B Triquetrorhabdulus rugosus & $844 \mathrm{~B}-15 \mathrm{H}-4,120 / 15 \mathrm{H}-5,60$ & $148.70-149.60$ & & \\
\hline T Discoaster signus & $844 \mathrm{~B}-15 \mathrm{H}-7,40 / 16 \mathrm{H}-1,120$ & $152.40-154.88$ & & \\
\hline T Cyclicargolithus floridanus & $844 \mathrm{~B}-17 \mathrm{H}-6,120 / 17 \mathrm{H}-7,60$ & $171.30-172.20$ & & \\
\hline T Sphenolithus heteromorphus & $844 \mathrm{~B}-19 \mathrm{H}-4,65 / 19 \mathrm{H}-4,120$ & $188.35-188.90$ & & \\
\hline B Reticulofenestra pseudoumbilicus & $844 \mathrm{~B}-19 \mathrm{H}-4,65 / 19 \mathrm{H}-4,120$ & $188.35-188.90$ & & \\
\hline T Helicosphaera ampliaperta & $844 \mathrm{~B}-26 \mathrm{X}-3,120 / 26 \mathrm{X}-4,90$ & $256.13-258.46$ & & \\
\hline B Discoaster signus & $844 \mathrm{~B}-28 \mathrm{X}-2,60 / 28 \mathrm{X}-2,122$ & $273.33-273.95$ & & \\
\hline
\end{tabular}

Notes: $\mathrm{T}=$ top occurrence, $\mathrm{B}=$ bottom occurrence, $\mathrm{T} \mathrm{c}=$ top occurrence of common and continuous species, and $\mathrm{B} \mathrm{c}=$ bottom occurrence of common and continuous species. Depths in meters composite depth (med).

Table 4. Position of calcareous nannofossil events at Site 845 .

\begin{tabular}{|c|c|c|c|c|}
\hline Event & $\begin{array}{c}\text { Interval } \\
(\mathrm{cm})\end{array}$ & $\begin{array}{l}\text { Depth } \\
\text { (mcd) }\end{array}$ & $\begin{array}{c}\text { Interval } \\
\text { (cm) }\end{array}$ & $\begin{array}{l}\text { Depth } \\
\text { (mcd) }\end{array}$ \\
\hline T Pseudoemiliania lacunosa & $845 \mathrm{~A}-2 \mathrm{H}-\mathrm{CC} / 3 \mathrm{H}-1,42$ & $18.09-18.38$ & & \\
\hline Reentrance medium Gephyrocapsa spp. & $845 \mathrm{~A}-3 \mathrm{H}-4,42 / 3 \mathrm{H}-5,42$ & $22.88-24.38$ & & \\
\hline T large Gephyrocapsa spp. & $845 \mathrm{~A}-3 \mathrm{H}-7,42 / 3 \mathrm{H}-\mathrm{CC}$ & $27.38-27.85$ & & \\
\hline B large Gephyrocapsa spp. & $845 \mathrm{~A}-4 \mathrm{H}-1,42 / 4 \mathrm{H}-2,42$ & $29.15-30.65$ & & \\
\hline T Calcidiscus macintyrei & $845 \mathrm{~A}-4 \mathrm{H}-3,42 / 4 \mathrm{H}-4,42$ & $32.15-33.65$ & & \\
\hline B medium Gephyrocapsa spp. & $845 \mathrm{~A}-4 \mathrm{H}-6,43 / 4 \mathrm{H}-7,42$ & $36.66-38.15$ & & \\
\hline T Discoaster brouweri & $845 \mathrm{~A}-5 \mathrm{H}-3,42 / 5 \mathrm{H}-3,150$ & $43.03-44.38$ & & \\
\hline T Discoaster pentaradiatus & $845 \mathrm{~A}-5 \mathrm{H}-7,50 / 5 \mathrm{H}-\mathrm{CC}$ & $49.11-49.60$ & & \\
\hline B Ceratolithus acutus & $845 \mathrm{~A}-8 \mathrm{H}-5,94 / 8 \mathrm{H}-5,120$ & $77.84-78.10$ & & \\
\hline T Discoaster quinqueramus & $845 \mathrm{~A}-8 \mathrm{H}-6,120 / 8 \mathrm{H}-7,12$ & $79.60-80.01$ & & \\
\hline B Amaurolithus amplificus & $845 \mathrm{~A}-10 \mathrm{H}-3,120 / 10 \mathrm{H}-4,13$ & $96.28-96.71$ & & \\
\hline T absence interval $R$. pseudoumbilicus & $845 \mathrm{~A}-10 \mathrm{H}-5,90 / 10 \mathrm{H}-5,145$ & $98.98-99.53$ & & \\
\hline B Amaurolithus primus & $845 \mathrm{~A}-11 \mathrm{H}-2,32 / 11 \mathrm{H}-4,32$ & $104.68-107.68$ & & \\
\hline B Discoaster berggrenii & $845 \mathrm{~A}-13 \mathrm{H}-1,145 / 13 \mathrm{H}-2,45$ & $126.16-126.66$ & $845 \mathrm{~B}-12 \mathrm{H}-4,150 / 12 \mathrm{H}-5,150$ & $125.08-126.58$ \\
\hline B Discoaster hamatus & $845 \mathrm{~A}-15 \mathrm{H}-7,50 / 16 \mathrm{H}-1,42$ & $156.46-158.85$ & $845 \mathrm{~B}-15 \mathrm{H}-2,120 / 15 \mathrm{H}-2,145$ & $157.10-157.35$ \\
\hline T Coccolithus miopelagicus & $845 \mathrm{~A}-16 \mathrm{H}-1,42 / 16 \mathrm{H}-1,120$ & $158.75-159.53$ & $845 \mathrm{~B}-15 \mathrm{H}-4,20 / 15 \mathrm{H}-4,40$ & $159.10-159.30$ \\
\hline B Catinaster coalitus & $845 \mathrm{~A}-16 \mathrm{H}-4,32 / 16 \mathrm{H}-4,78$ & $163.15-163.61$ & & \\
\hline T c Discoaster kugleri & & & $845 \mathrm{~B}-16 \mathrm{H}-6,120 / 16 \mathrm{H}-7,20$ & $174.00-174.50$ \\
\hline B c Discoaster kugleri & & & $845 \mathrm{~B}-17 \mathrm{H}-5,10 / 17 \mathrm{H}-5,42$ & $181.00-181.32$ \\
\hline T Coronocyclus nitescens & $845 \mathrm{~A}-19 \mathrm{H}-1,78 / 19 \mathrm{H}-2,42$ & $190.54-191.68$ & $845 \mathrm{~B}-18 \mathrm{H}-5,10 / 18 \mathrm{H}-5.78$ & $190.50-191.18$ \\
\hline B Discoaster kugleri & & & $845 \mathrm{~B}-18 \mathrm{H}-5,78 / 18 \mathrm{H}-5,120$ & $191.18-191.60$ \\
\hline B Calcidiscus macintyrei (?) & $845 \mathrm{~A}-19 \mathrm{H}-1,78 / 19 \mathrm{H}-2,42$ & $190.54-191.68$ & $845 \mathrm{~B}-18 \mathrm{H}-5,78 / 18 \mathrm{H}-5,120$ & $191.18-191.60$ \\
\hline T Calcidiscus premacintyrei & & & $1845 \mathrm{~B}-8 \mathrm{H}-7,23 / 18 \mathrm{H}-7,50$ & $194.00-194.99$ \\
\hline B Triquetrorhabdulus rugosus & $845 \mathrm{~A}-20 \mathrm{H}-4,78 / 20 \mathrm{H}-5,42$ & $206.21-207.35$ & & \\
\hline T Discoaster signus & $845 \mathrm{~A}-20 \mathrm{H}-6,42 / 20 \mathrm{H}-6,78$ & $208.85-209.21$ & & \\
\hline T Cyclicargolithus floridanus & $845 \mathrm{~A}-22 \mathrm{H}-1,78 / 22 \mathrm{H}-1,143$ & $223.61-224.26$ & & \\
\hline T Sphenolithus heteromorphus & $845 \mathrm{~A}-23 \mathrm{X}-4,46 / 23 \mathrm{X}-4,86$ & $237.29-237.69$ & & \\
\hline B Reticulofenestra pseudoumbilicus & $845 \mathrm{~A}-23 \mathrm{X}-4,46 / 23 \mathrm{X}-4.86$ & $237.29-237.69$ & & \\
\hline T Helicosphaera ampliaperta & $845 \mathrm{~A}-27 \mathrm{X}-6,42 / 27 \mathrm{X}-6,118$ & $278.95-279.71$ & & \\
\hline B Discoaster signus & $845 \mathrm{~A}-29 \mathrm{X}-4,40 / 29 \mathrm{X}-4,120$ & $294.73-295.53$ & & \\
\hline T acme Discoaster deflandrei & $845 \mathrm{~A}-29 \mathrm{X}-4,120 / 29 \mathrm{X}-5,120$ & $295.53-297.03$ & & \\
\hline
\end{tabular}

Note: See note to Table 3 . 


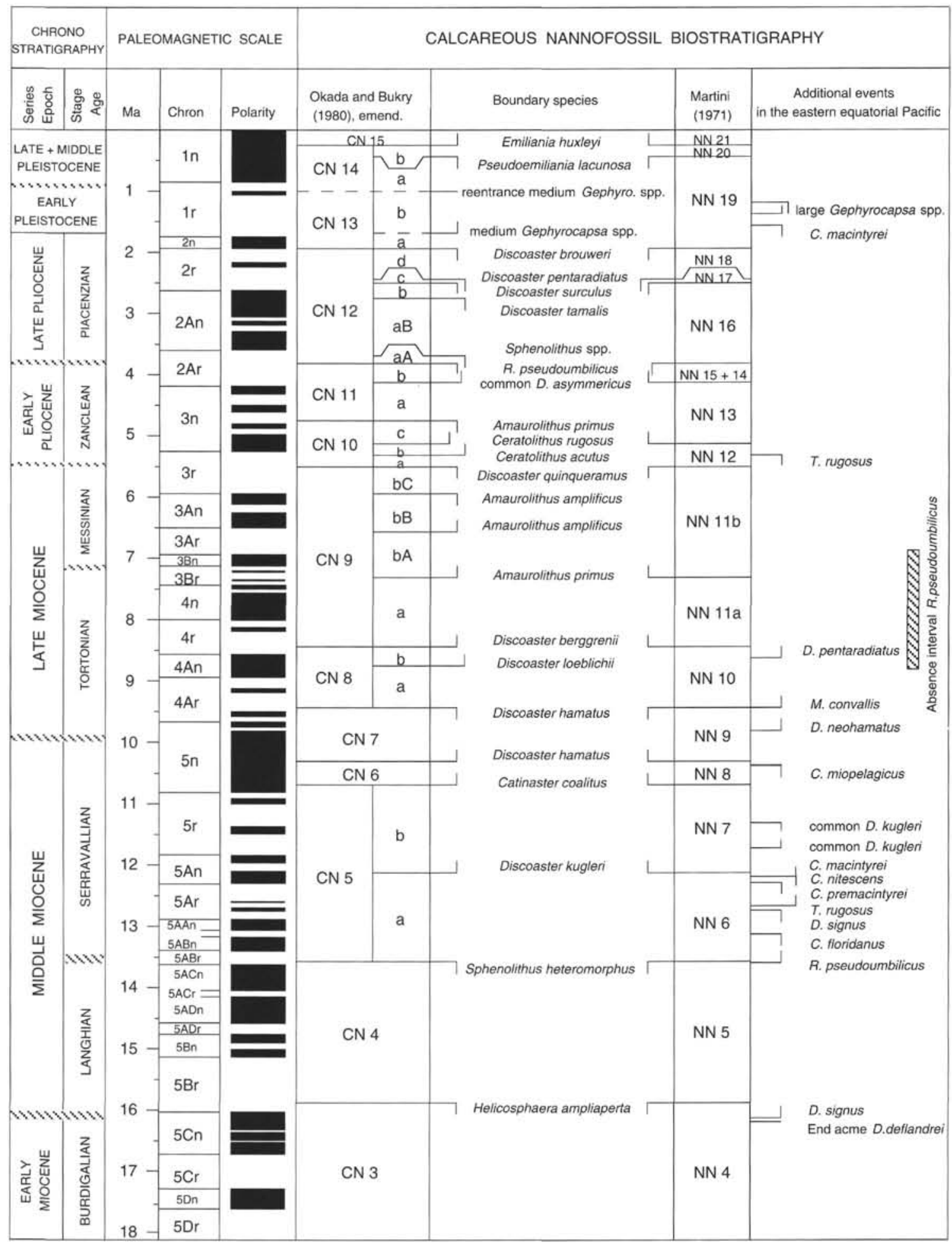

Figure 2. Adopted chronostratigraphy and calcareous nannofossil biostratigraphy and biochronology. Geomagnetic polarity time scale after Cande and Kent (1992), with revised ages after Shackleton et al. (this volume). 


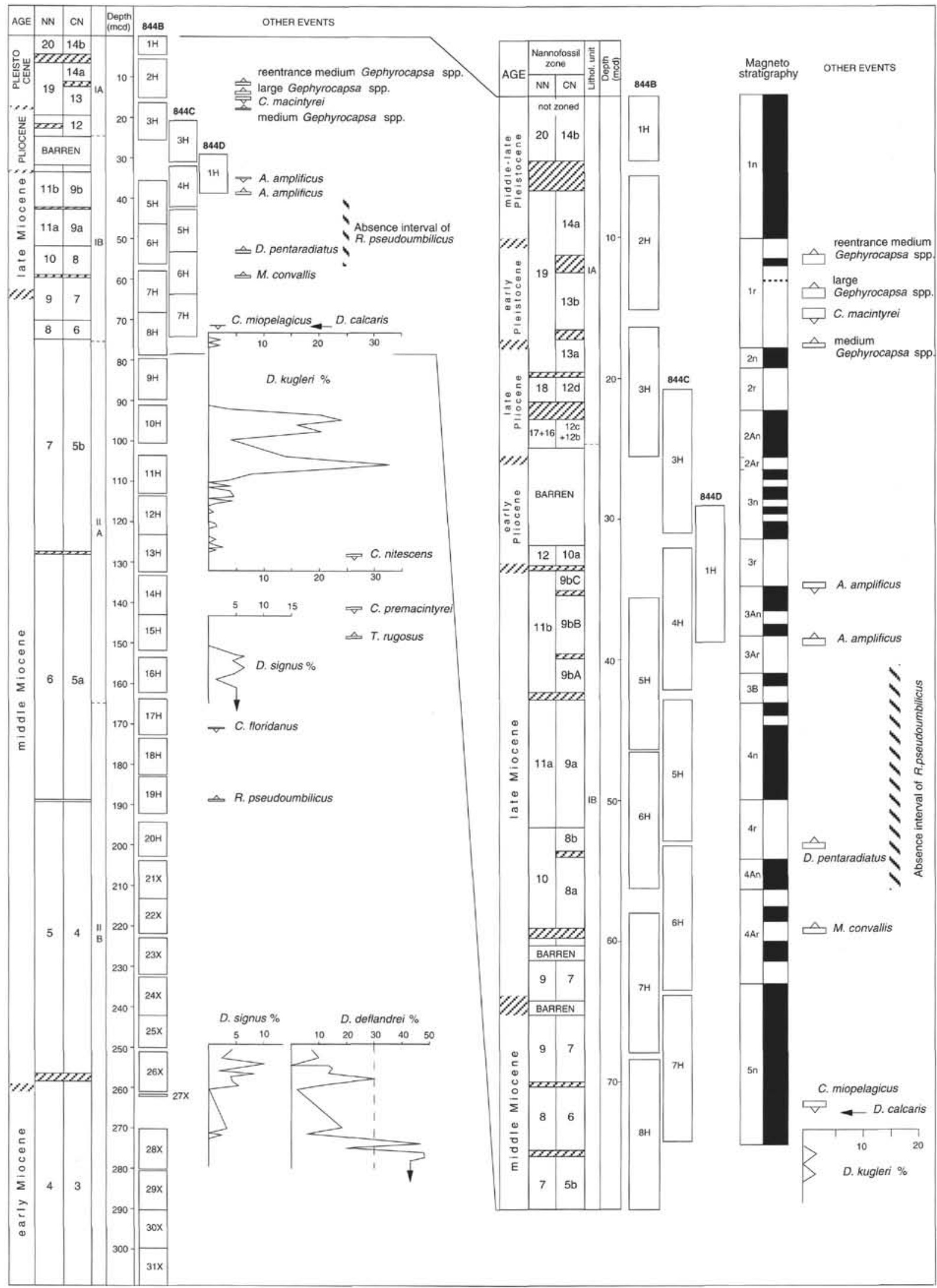

Figure 3. Chronostratigraphy and calcareous nannofossil biostratigraphy at Site 844. Magnetostratigraphy from site chapters in Mayer, Pisias, Janecek, et al. (1992) and Schneider et al. (this volume). "Striped" areas at zonal boundaries represent intervals (sample spacing) within which biostratigraphic events occur. 


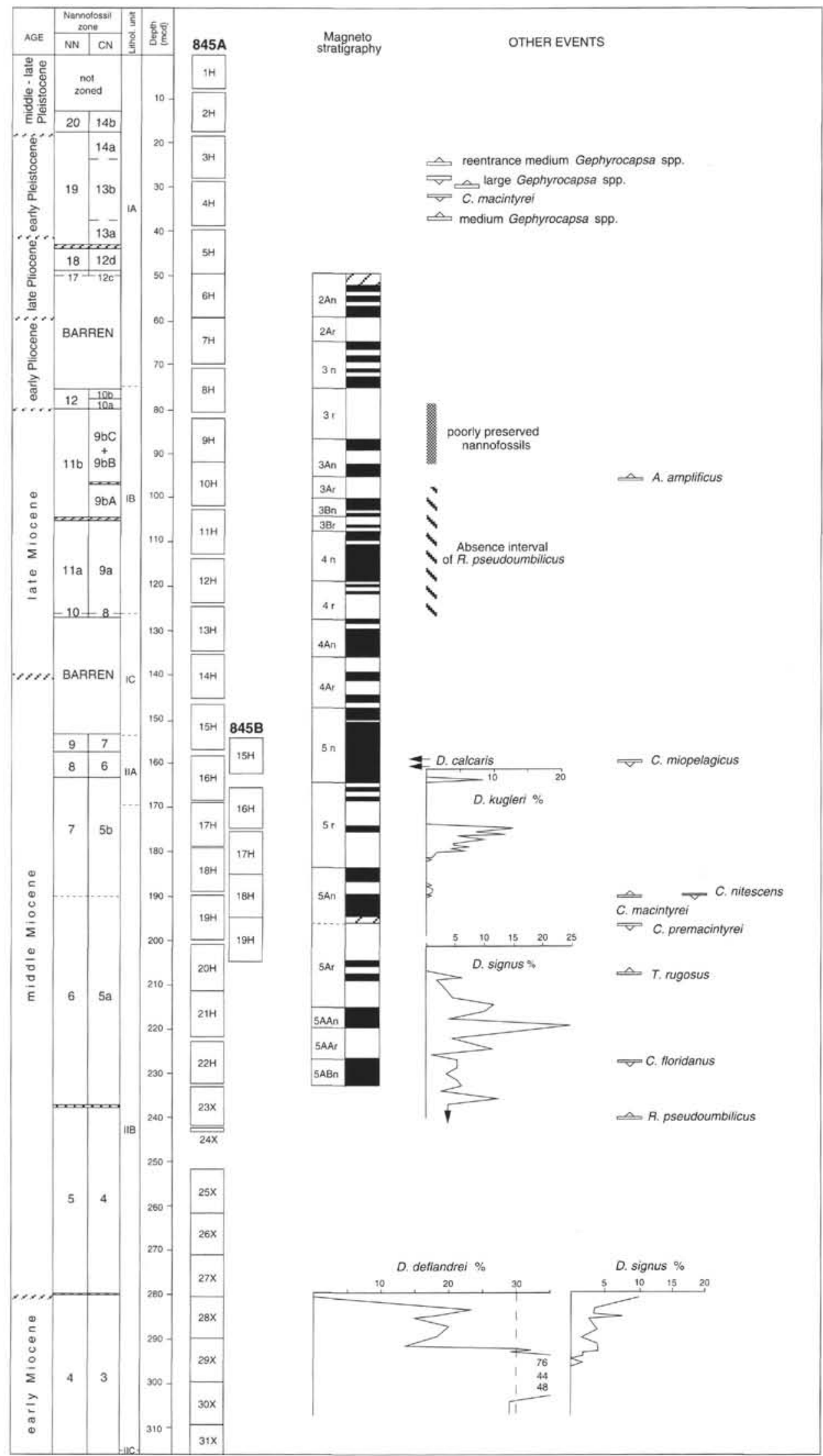

Figure 4. Chronostratigraphy and calcareous nannofossil biostratigraphy at Site 845 . Notation as specified in Figure 3. 
Table 5. Position of calcareous nannofossil events at Site $\mathbf{8 4 6 .}$

\begin{tabular}{|c|c|c|}
\hline Event & $\begin{array}{l}\text { Interval } \\
(\mathrm{cm})\end{array}$ & $\begin{array}{l}\text { Depth } \\
\text { (mcd) }\end{array}$ \\
\hline Pseudoemiliania lacunosa & $846 \mathrm{~B}-2 \mathrm{H}-7,20 / 2 \mathrm{H}-\mathrm{CC}, 5$ & $16.80-17.39$ \\
\hline Reentrance medium Gephyrocapsa spp. & $846 \mathrm{~B}-4 \mathrm{H}-6,45 / 4 \mathrm{H}-6,120$ & $37.10-37.85$ \\
\hline T large Gephyrocapsa spp. & $846 \mathrm{~B}-5 \mathrm{H}-3,120 / 5 \mathrm{H}-4,40$ & $44.90-45.60$ \\
\hline B large Gephyrocapsa spp. & $846 \mathrm{~B}-6 \mathrm{H}-3,120 / 6 \mathrm{H}-4,39$ & $55.70-56.39$ \\
\hline T Calcidiscus macintyrei & $846 \mathrm{~B}-6 \mathrm{H}-5,40 / 6 \mathrm{H}-5,120$ & $57.90-58.70$ \\
\hline B medium Gephyrocapsa spp. & $846 \mathrm{~B}-6 \mathrm{H}-6,40 / 6 \mathrm{H}-\mathrm{CC}, 5$ & $59.40-60.04$ \\
\hline T Discoaster brouweri & $846 \mathrm{~B}-8 \mathrm{H}-3,43 / 8 \mathrm{H}-3,120$ & $77.13-77.90$ \\
\hline T Discoaster surculus & $846 \mathrm{~B}-10 \mathrm{H}-1,60 / 10 \mathrm{H}-1,135$ & $96.15-96.90$ \\
\hline T Discoaster tamalis & $846 \mathrm{~B}-12 \mathrm{H}-2,120 / 12 \mathrm{H}-3,60$ & $118.00-120.40$ \\
\hline T Sphenolithus spp. & $846 \mathrm{~B}-14 \mathrm{H}-4,120 / 14 \mathrm{H}-5,60$ & $143.85-144.75$ \\
\hline T Reticulofenestra pseudoumbilicus & $846 \mathrm{~B}-14 \mathrm{H}-\mathrm{CC}, 13 / 15 \mathrm{H}-1,60$ & $147.71-150.80$ \\
\hline B c Discoaster asymmetricus & $846 \mathrm{~B}-15 \mathrm{H}-\mathrm{CC} / 16 \mathrm{H}-1,60$ & $160.32-160.80$ \\
\hline T Amaurolithus primus & $846 \mathrm{~B}-17 \mathrm{H}-1,120 / 17 \mathrm{H}-2,50$ & $171.95-172.75$ \\
\hline T Ceratolithus acutus & $846 \mathrm{~B}-19 \mathrm{H}-1,40 / 19 \mathrm{H}-\mathrm{I}, 120$ & $192.70-193.50$ \\
\hline B Ceratolithus rugosus & $846 \mathrm{~B}-19 \mathrm{H}-3,120 / 19 \mathrm{H}-4,40$ & $196.50-197.20$ \\
\hline B Ceratolithus acutus & $846 \mathrm{~B}-20 \mathrm{H}-3,120 / 20 \mathrm{H}-4,50$ & $207.80-208.60$ \\
\hline T Discoaster quinqueramus & $846 \mathrm{~B}-21 \mathrm{H}-4,50 / 21 \mathrm{H}-4,120$ & $219.45-220.15$ \\
\hline T circular reticulofenestrids & $846 \mathrm{~B}-23 \mathrm{X}-2,120 / 23 \mathrm{X}-3,50$ & $243.20-244.00$ \\
\hline T Amaurolithus amplificus & $846 \mathrm{~B}-23 \mathrm{X}-3,50 / 23 \mathrm{X}-3,120$ & $244.00-244.70$ \\
\hline B Amaurolithus amplificus & $846 \mathrm{~B}-23 \mathrm{X}-\mathrm{CC}, 10 / 24 \mathrm{X}-1,40$ & $250.15-252.00$ \\
\hline B circular reticulofenestrids & $846 \mathrm{~B}-25 \mathrm{X}-2,39 / 25 \mathrm{X}-3,50$ & $262.69-264.30$ \\
\hline T absence interval $R$. pseudoumbilicus & $846 \mathrm{D}-26 \mathrm{X}-4,120 / 26 \mathrm{X}-5,50$ & $279.30-280.10$ \\
\hline B Amaurolithus primus & $849 \mathrm{D}-26 \mathrm{X}-6,120 / 26 \mathrm{X}-7,23$ & $282.30-282.83$ \\
\hline T Minvlitha convallis & $846 \mathrm{~B}-29 \mathrm{X}-2,60 / 29 \mathrm{X}-3,60$ & $301.40-302.90$ \\
\hline B Discoaser berggrenii & $846 \mathrm{~B}-29 \mathrm{X}-5,60 / 29 \mathrm{X}-5,120$ & $305.90-306.50$ \\
\hline B Discoaster loeblichii & $846 \mathrm{~B}-30 \mathrm{X}-3,60 / 30 \mathrm{X}-4,60$ & $312.60-314.10$ \\
\hline B absence interval $R$. pseudoumbilicus & $846 \mathrm{~B}-30 \mathrm{X}-5,60 / 30 \mathrm{X}-6,60$ & $315.60-317.10$ \\
\hline B Minylitha convallis & $846 \mathrm{~B}-32 \mathrm{X}-1,60 / 32 \mathrm{X}-2,60$ & $328.80-330.30$ \\
\hline T Discoaster hamatus & $846 \mathrm{~B}-32 \mathrm{X}-5,60 / 32 \mathrm{X}-5,120$ & $334.80-335.40$ \\
\hline B Discoaster hamatus & $846 \mathrm{~B}-33 \mathrm{X}-4,120 / 33 \mathrm{X}-5,60$ & $343.60-344.50$ \\
\hline T Coccolithus miopelagicus & $846 \mathrm{~B}-33 \mathrm{X}-5,120 / 33 \mathrm{X}-6,60$ & $345.10-346.00$ \\
\hline B Catinaster coalitus & $846 \mathrm{~B}-33 \mathrm{X}-6,120 / 33 \mathrm{X}-7,34$ & $346.60-347.24$ \\
\hline T c Discoaster kugleri & $846 \mathrm{~B}-35 \mathrm{X}-2,60 / 35 \mathrm{X}-2,120$ & $359.20-359.80$ \\
\hline B c Discoaster kugleri & $846 \mathrm{~B}-36 \mathrm{X}-1,36 / 36 \mathrm{X}-2,60$ & $367.16-368.90$ \\
\hline B Discoaster kugleri & $846 \mathrm{~B}-38 \mathrm{X}-6,50 / 38 \mathrm{X}-6,120$ & $394.10-394.80$ \\
\hline $\mathrm{T} C$. floridanus $+C$. nitescens & 846B-38X-CC, $10 / 40 \mathrm{X}-1,40$ & $395.11-405.80$ \\
\hline T Sphenolithus heteromorphus & $846 \mathrm{~B}-38 \mathrm{X}-\mathrm{CC}, 10 / 40 \mathrm{X}-1,40$ & $395.11-405.80$ \\
\hline B Reticulofenestra pseudoumbilicus & $846 \mathrm{~B}-38 \mathrm{X}-\mathrm{CC}, 10 / 40 \mathrm{X}-1,40$ & $395.11-405.80$ \\
\hline T Helicosphaera ampliaperta & $846 \mathrm{~B}-41 \mathrm{X}-\mathrm{CC}, 9 / 42 \mathrm{X}-1,79$ & $421.87-425.49$ \\
\hline T acme Discoaster deflandrei & $846 \mathrm{~B}-42 \mathrm{X}-\mathrm{CC}, 12 / 43 \mathrm{X}-\mathrm{CC}, 3$ & $426.00-434.33$ \\
\hline Discoaster signus & $846 \mathrm{~B}-42 \mathrm{X}-\mathrm{CC}, 12 / 43 \mathrm{X}-\mathrm{CC}, 3$ & $426.00-434.33$ \\
\hline
\end{tabular}

Note: See note to Table 3.

Almost all the known Pleistocene nannofossil events have been observed. Because we only used the light microscope technique to examine the nannofossils, we were not able to record the appearance (CN15/CN14b and NN21/NN20 boundary) and the increase in abundance of Emiliania huxleyi in the upper Pleistocene interval. Detection of the other Pleistocene events follows the rationale in Rio et al. (1990b) and Raffi et al. (1993), which is primarily based on morphometric studies of gephyrocapsids. This group represents an important component of Pleistocene nannofossil assemblages (see discussion on taxonomy of gephyrocapsids in Raffi et al., 1993). A biometrically based definition of the group provides a precise tool in the correlation of lower Pleistocene sequences (Raffi et al., 1993; Rio et al., in press).

In the interval from the Chron $1 \mathrm{n} / 1 \mathrm{r}$.1r boundary (Brunhes/ Matuyama boundary) to the top of Chron $2 \mathrm{n}$ (Olduvai), the nannofossil events recorded are (1) the reentrance of medium Gephyrocapsa spp. (mainly composed of $G$. omega-G. parallela morphotypes); (2) the disappearance of large and medium Gephyrocapsa spp.; (3) the first occurrence (FO) of large Gephyrocapsa spp.; (4) the last occurrence (LO) of Calcidiscus macintyrei; and (5) the FO of medium Gephyrocapsa spp.

The use of these events in the biostratigraphic classification of the lower-middle Pleistocene improves the stratigraphic resolution in this time interval. Note that some events correspond to the boundary definitions of the "standard" zones, and most events are isochronous over wide areas (Raffi et al., 1993). The reentrance of medium Gephyrocapsa spp. probably corresponds to boundary $\mathrm{CN} 14 \mathrm{a} / \mathrm{CN} 13 \mathrm{~b}$, defined by the appearance of $G$. oceanica s.s. by Bukry (1973), who recorded $G$. omega as occurring close to this boundary.

The appearance of medium-sized Gephyrocapsa spp. $(\geq 4 \mu \mathrm{m})$ has been used to recognize the $\mathrm{CN} 13 \mathrm{~b} / \mathrm{CN} 13$ a boundary, originally de-
Table 6. Position of calcareous nannofossil events at Site 847B.

\begin{tabular}{llc}
\hline \multicolumn{1}{c}{ Event } & \multicolumn{1}{c}{$\begin{array}{c}\text { Interval } \\
(\mathrm{cm})\end{array}$} & $\begin{array}{c}\text { Depth } \\
(\mathrm{mcd})\end{array}$ \\
\hline B Emiliania huxleyi & $1 \mathrm{H}-3,120 / 1 \mathrm{H}-4,120$ & $3.20-4.70$ \\
T Pseudoemiliania lacunosa & $2 \mathrm{H}-5,120 / 2 \mathrm{H}-6,51$ & $13.83-14.64$ \\
Reentrance medium Gephyrocapsa $\mathrm{spp}$. & $4 \mathrm{H}-2,60 / 4 \mathrm{H}-2,120$ & $30.43-31.03$ \\
T large Gephyrocapsa spp. & $5 \mathrm{H}-1,60 / 5 \mathrm{H}-1,120$ & $38.40-39.00$ \\
B large Gephyrocapsa spp. & $5 \mathrm{H}-7,40 / 5 \mathrm{H}-\mathrm{CC}$ & $47.20-47.70$ \\
T Calcidiscus macintyrei & $6 \mathrm{H}-1,60 / 6 \mathrm{H}-1,19$ & $50.18-50.77$ \\
B medium Gephyrocapsa spp. & $6 \mathrm{H}-3,120 / 6 \mathrm{H}-4,60$ & $55.28-56.18$ \\
T Discoaster brouweri & $7 \mathrm{H}-6,60 / 7 \mathrm{H}-6,120$ & $68.85-69.45$ \\
T Discoaster surculus & $9 \mathrm{H}-3,60 / 9 \mathrm{H}-1,120$ & $86.08-86.68$ \\
T Discoaster tamalis & $9 \mathrm{H}-6,120 / 9 \mathrm{H}-7,15$ & $91.18-91.63$ \\
T Sphenolithus spp. & $12 \mathrm{H}-3,60 / 12 \mathrm{H}-3,120$ & $118.13-118.73$ \\
T Reticulofenestra pseudoumbilicus & $12 \mathrm{H}-5,60 / 12 \mathrm{H}-5,120$ & $121.13-121.73$ \\
B c Discoaster asymmetricus & $14 \mathrm{H}-5,60 / 14 \mathrm{H}-5,124$ & $140.58-141.22$ \\
T Amaurolithus primus & $14 \mathrm{H}-5,124 / 14 \mathrm{H}-6,60$ & $141.22-142.08$ \\
T Ceratolithus acutus & $17 \mathrm{X}-3,60 / 17 \mathrm{X}-4,60$ & $168.75-170.25$ \\
B Ceratolithus rugosus & $17 \mathrm{X}-5,123 / 17 \mathrm{X}-6,60$ & $172.38-173.25$ \\
B Ceratolithus acutus & $18 \mathrm{X}-7,3 / 18 \mathrm{X}-7,15$ & $183.78-183.90$ \\
T Discoaster quinqueramus & $20 \mathrm{X}-3,93 / 20 \mathrm{X}-4,60$ & $197.18-198.35$ \\
\hline
\end{tabular}

Note: See note to Table 3

fined (Bukry, 1973) by the FO of Gephyrocapsa caribbeanica, a species difficult to recognize in the optical microscope. The use of the appearance of medium-sized Gephyrocapsa spp. allows one to define more easily the $\mathrm{CN} 13 \mathrm{~b} / \mathrm{CN} 13 \mathrm{a}$ boundary. This event occurs in the same stratigraphic interval as the FO of $G$. caribbeanica (after the LO of Discoaster brouweri and before the LO of Calcidiscus macintyrei). The appearance of medium Gephyrocapsa spp. represents the best approximation of the Pliocene/Pleistocene boundary, as defined in the boundary stratotype section of Vrica (southern Italy) (Aguirre and Pasini, 1985). 


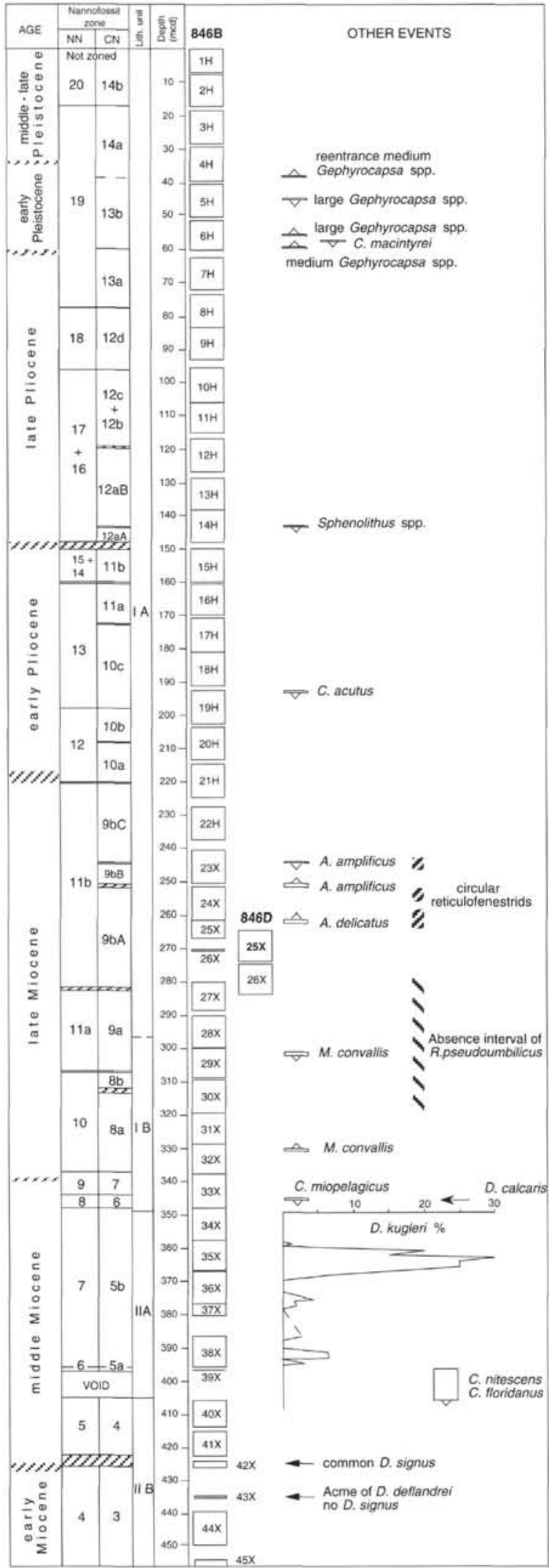

Figure 5. Chronostratigraphy and calcareous nannofossil biostratigraphy at Site 846. "Striped" areas at zonal boundaries represent intervals (sample spacing) within which biostratigraphic events occur.

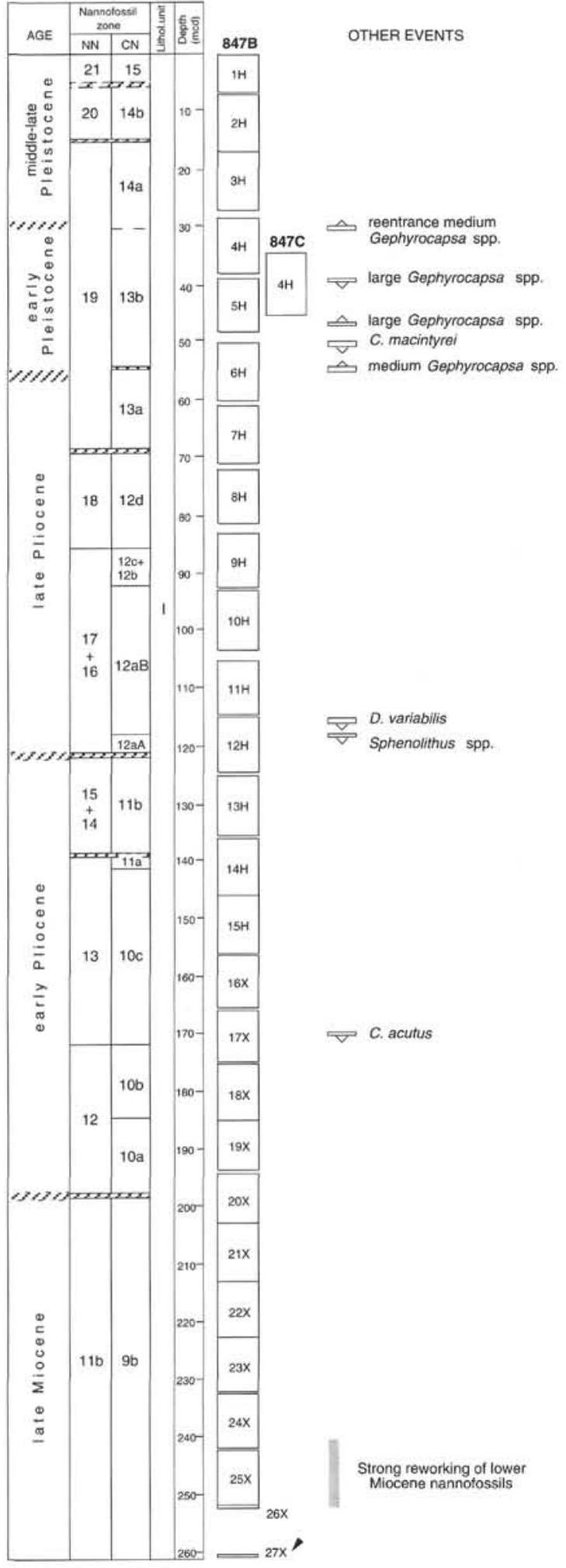

Figure 6 . Chronostratigraphy and calcareous nannofossil biostratigraphy at Site 847. Notation as specified in Figure 5.

The extinction of Helicosphaera sellii is confirmed to be an unreliable event in the Pacific, based on the diachroneity clearly demonstrated by Backman and Shackleton (1983) and Raffi et al. (1993), who compared Pacific Ocean records with those from the Atlantic Ocean and the Mediterranean Sea (e.g., Takayama and Sato, 1987; Rio et al., 1990b). In the Leg 138 sites, this species is rare and is 
Table 7. Position of calcareous nannofossil events at Site 848 .

\begin{tabular}{|c|c|c|}
\hline Event & $\begin{array}{c}\text { Interval } \\
(\mathrm{cm})\end{array}$ & $\begin{array}{l}\text { Depth } \\
\text { (mcd) }\end{array}$ \\
\hline T Pseudoemiliania lacunosa & $848 \mathrm{~A}-1 \mathrm{H}-4,60 / 1 \mathrm{H}-5,60$ & $5.3-6.8$ \\
\hline Reentrance medium Gephyrocapsa spp. & $848 \mathrm{~B}-3 \mathrm{H}-1,70 / 3 \mathrm{H}-1,80$ & $16.35-16.40$ \\
\hline T large Gephyrocapsa spp. & $848 \mathrm{~B}-3 \mathrm{H}-3,60 / 3 \mathrm{H}-3,120$ & $19.25-19.85$ \\
\hline B large Gephyrocapsa spp. & $848 \mathrm{~B}-3 \mathrm{H}-5,120 / 3 \mathrm{H}-6,40$ & $22.85-23.55$ \\
\hline T Calcidiscus macintyrei & $848 \mathrm{C}-3 \mathrm{H}-5,20 / 3 \mathrm{H}-5,40$ & $24.22-24.42$ \\
\hline B medium Gephyrocapsa spp. & $848 \mathrm{C}-3 \mathrm{H}-5,40 / 3 \mathrm{H}-5,50$ & $24.42-24.52$ \\
\hline T Discoaster brouweri & $848 \mathrm{C}-3 \mathrm{H}-6,120 / 3 \mathrm{H}-7,10$ & $26.72-27.12$ \\
\hline T Discoaster pentaradiatus & $848 \mathrm{~B}-4 \mathrm{H}-4,40 / 4 \mathrm{H}-4,80$ & $30.45-30.85$ \\
\hline T Discoaster surculus & $848 \mathrm{~B}-4 \mathrm{H}-4,40 / 4 \mathrm{H}-4,80$ & $30.45-30.85$ \\
\hline T Discoaster tamalis & $848 \mathrm{~B}-4 \mathrm{H}-5,23 / 4 \mathrm{H}-5,85$ & $31.78-32.40$ \\
\hline T Sphenolithus spp. & $848 \mathrm{~B}-4 \mathrm{H}-\mathrm{CC} / 5 \mathrm{H}-1,42$ & $35.52-36.77$ \\
\hline T Reticulofenestra pseudoumbilicus & $848 \mathrm{~B}-5 \mathrm{H}-1,95 / 5 \mathrm{H}-1,120$ & $37.30-37.55$ \\
\hline B c Discoaster asymmetricus & $848 \mathrm{~B}-5 \mathrm{H}-2,50 / 5 \mathrm{H}-2,120$ & $38.35-39.05$ \\
\hline T Amaurolithus primus & $848 \mathrm{~B}-5 \mathrm{H}-2,127 / 5 \mathrm{H}-3,62$ & $39.12-39.97$ \\
\hline T Ceratolithus acutus & $848 \mathrm{~B}-6 \mathrm{H}-1,75 / 6 \mathrm{H}-2,35$ & $46.65-47.75$ \\
\hline B Ceratolithus rugosus & $848 \mathrm{~B}-6 \mathrm{H}-4,35 / 6 \mathrm{H}-4,65$ & $50.75-51.05$ \\
\hline B Ceratolithus acutus & $848 \mathrm{~B}-6 \mathrm{H}-5,35 / 6 \mathrm{H}-5,75$ & $52.25-52.65$ \\
\hline T Discoaster quinqueramus & $848 \mathrm{~B}-7 \mathrm{H}-1,50 / 7 \mathrm{H}-1,95$ & $56.90-57.35$ \\
\hline T Amaurolithus amplificus & $848 \mathrm{C}-7 \mathrm{H}-2,25 / 7 \mathrm{H}-2,50$ & $62.54-62.79$ \\
\hline B Amaurolithus amplificus & $848 \mathrm{C}-7 \mathrm{H}-6,145 / 7 \mathrm{H}-7,20$ & $69,74-69.99$ \\
\hline T absence interval $R$. pseudoumbilicus & $848 \mathrm{C}-8 \mathrm{H}-6,40 / 8 \mathrm{H}-6,60$ & $75.00-75.20$ \\
\hline B Amaurolithus primus & $848 \mathrm{C}-8 \mathrm{H}-6,80 / 8 \mathrm{H}-6,140$ & $79.94-80.54$ \\
\hline T Minylitha convallis & $848 \mathrm{~B}-9 \mathrm{H}-5,85 / 9 \mathrm{H}-5,119$ & $85.15-85.89$ \\
\hline B Discoaster berggrenii (?) & $848 \mathrm{~B}-9 \mathrm{H}-5,119 / 9 \mathrm{H}-6,40$ & $85.89-86.60$ \\
\hline B absence interval $R$. pseudoumbilicus & $848 \mathrm{~B}-9 \mathrm{H}-6,119 / 9 \mathrm{H}-7,10$ & $86.99-87.40$ \\
\hline B Discoaster loeblichii & $848 \mathrm{~B}-9 \mathrm{H}-6,119 / 9 \mathrm{H}-7,10$ & $86.99-87.40$ \\
\hline B Minylitha convallis & $848 \mathrm{~B}-10 \mathrm{H}-2,120 / 10 \mathrm{H}-2,150$ & $91.50-91.80$ \\
\hline T Discoaster hamatus & $848 \mathrm{C}-10 \mathrm{H}-1,100 / 10 \mathrm{H}-1,125$ & $93.32-93.57$ \\
\hline T Discoaster neohamatus & $848 \mathrm{C}-10 \mathrm{H}-2,75 / 10 \mathrm{H}-2,100$ & $94.57-94.82$ \\
\hline B Discoaster hamatus & $848 \mathrm{C}-10 \mathrm{H}-5,30 / 10 \mathrm{H}-5,50$ & $98.62-98.82$ \\
\hline T Coccolithus miopelagicus & $848 \mathrm{C}-10 \mathrm{H}-5,50 / 10 \mathrm{H}-5,75$ & $98.82-99.03$ \\
\hline
\end{tabular}

Note: See note to Table 3.

Table 8. Position of calcareous nannofossil events at Site 849.

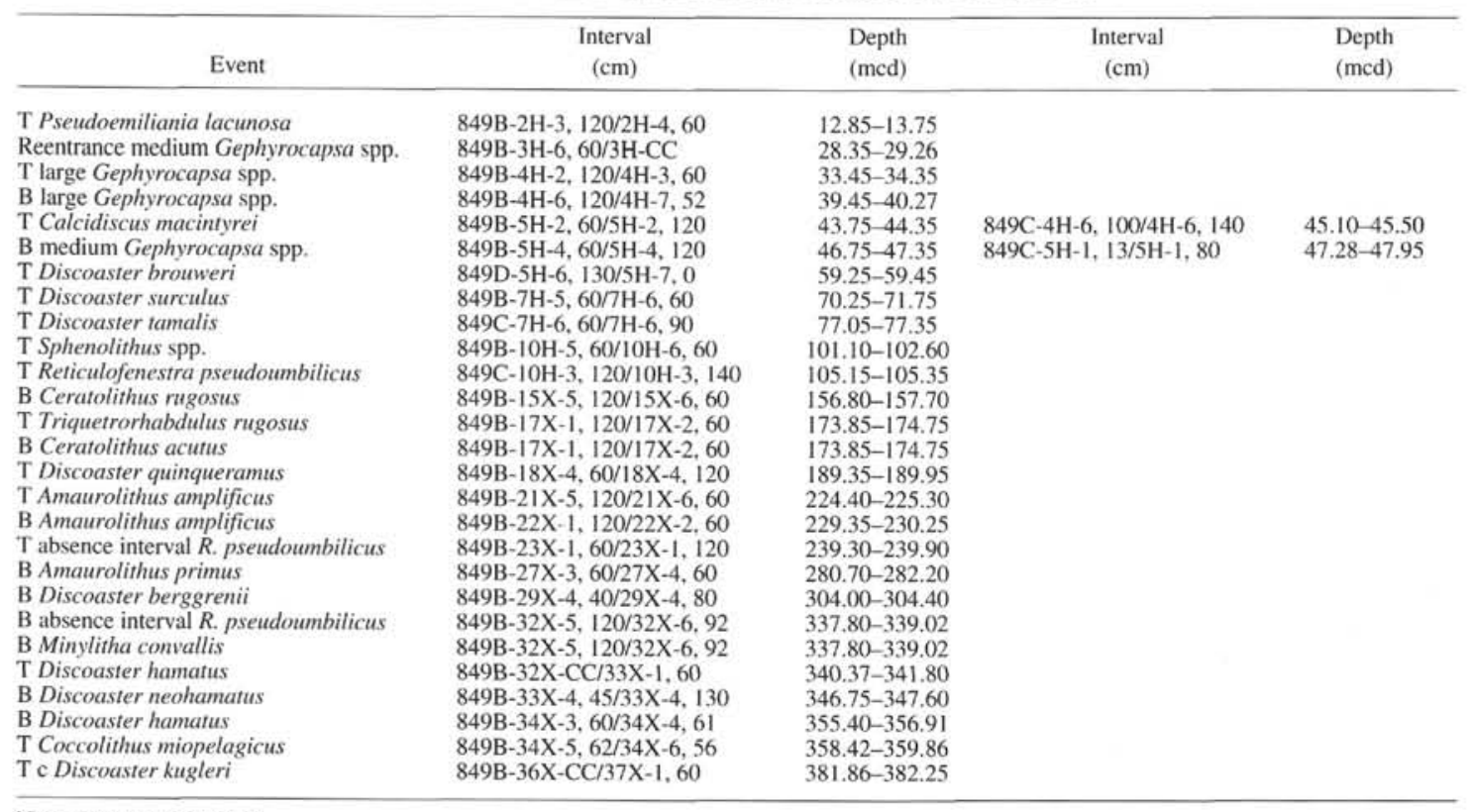

Note: See note to Table 3 .

scattered in the upper part of its range. Helicosphaera sellii shows a peak in abundance close to (just above and just below) the appearance of medium Gephyrocapsa spp.

\section{Pliocene}

All the zones of Bukry (1973) and Martini (1971) can be differentiated in the Pliocene sections at all sites, except Sites 844 and 845, where nannofossil barren zones represent episodes of severe carbonate dissolution. Subzonal boundaries within Zones CN12 and CN11 are not easily recognized because of the scarcity of markers such as discoasterid and ceratolithid species.

\section{Zone CN12 (Zones NN18-NN17-NN16)}

The LO of Discoaster brouweri (CN13/CN12 and NN19/NN18 boundary) was recorded in all Leg 138 sites. The boundary is characterized by the LO of Discoaster triradiatus, a species that occurs in abundance only at the end of the range of $D$. brouweri (Takayama, 1970). This event was not clearly detected because $D$. triradiatus is 


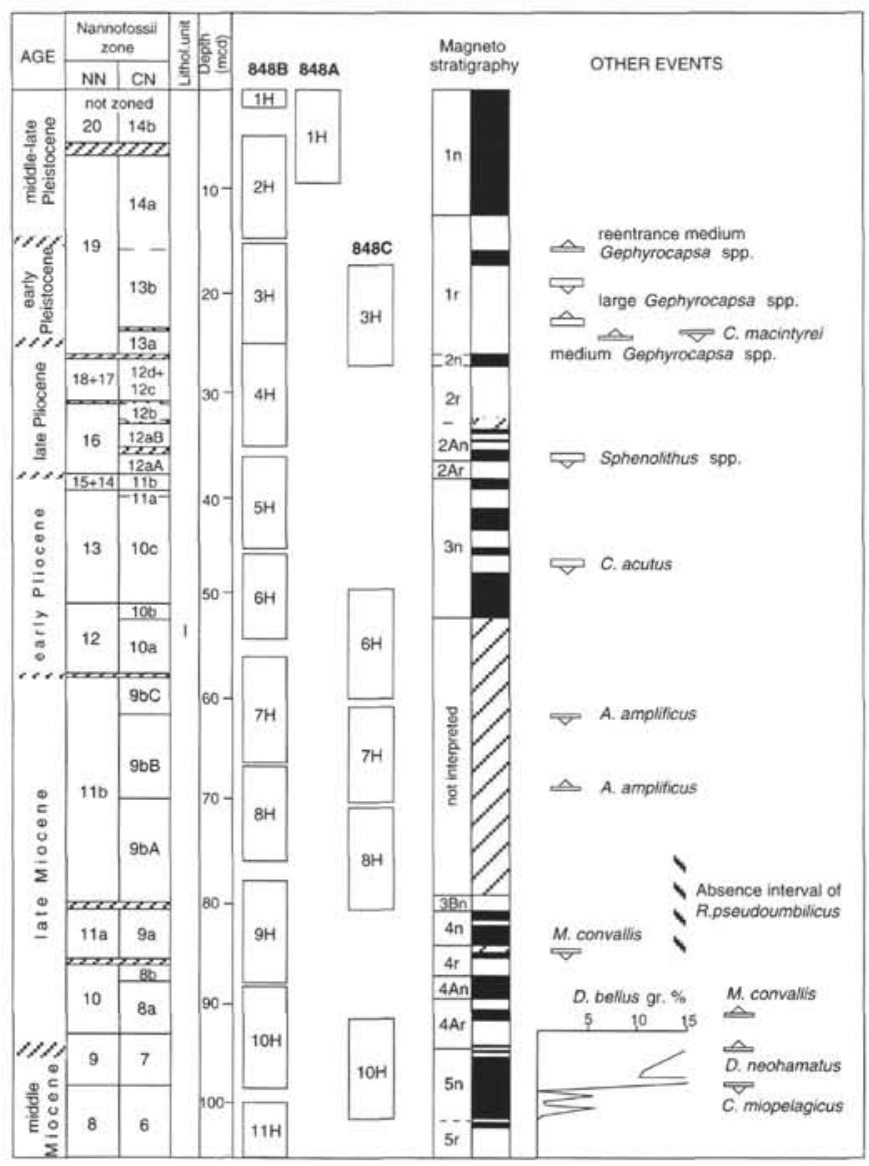

Figure 7. Chronostratigraphy and calcareous nannofossil biostratigraphy at Site 848. Notation as specified in Figure 3.

never present abundantly and consistently in the sections studied. This pattern of distribution also prevents the recognition of the increase in proportion ( $>20 \%$ ) of $D$. triradiatus relative to D. brouweri, a datum introduced by Backman and Shackleton (1983).

The successive and closely spaced extinctions of Discoaster pentaradiatus and Discoaster surculus define the boundaries between Subzones CN12d-CN12c (Zones NN18-NN17) and Subzones $\mathrm{CN} 12 \mathrm{c}-\mathrm{CN} 12 \mathrm{~b}$ (Zones NN17-NN16), respectively. The two events are often recorded together (Backman and Pestiaux, 1986; Rio et al., 1990 b). In the Leg 138 sites, $D$. surculus and $D$. pentaradiatus are generally rare or absent in the late Pliocene section. In all sites except Sites 852 and $853, D$. pentaradiatus, when present, leaves the stratigraphic record together with $D$. surculus.

Note that the highly variable distribution and generally low abundance or absence of discoasterids, and thus their unreliability as biostratigraphic markers in the upper Pliocene, are particularly evident at sites strongly influenced by upwelling (such as Sites 849,850 , and 851 in the western transect and Sites 844,845 , and 846 in the eastern transect). Similar low abundances and scattered occurrences of other marker species of discoasterids and other nannofossils have been observed at various levels in Leg 138 holes. These distribution patterns may have been influenced by varying productivity pressures, as suggested by Chepstow-Lusty et al. $(1989,1992)$, who showed that regions of high productivity are associated with lower discoasterid abundance.

Discoaster tamalis becomes extinct before $D$. surculus, thus defining the boundary between Subzones CN12b and CN12a. In the material studied, $D$. tamalis, together with $D$. asymmetricus and members of the Discoaster variabilis group, have an irregular distribution, being more common in sites located out of the equatorial zone.

In the lower part of Subzone CN12a (Zone NN16), we record the LO of the last representatives of the genus Sphenolithus (S. abies and
S. neoabies). This event occurs shortly above the LO of Reticulofenestra pseudoumbilicus and allows us to divide the CN12a Subzone further, defining Subzone "CN12aA" as proposed by Bukry (1991). A similar extinction of the last sphenoliths with respect to the final occurrence of $R$. pseudoumbilicus has been recorded in oceanic sediments (Backman and Shackleton, 1983; Rio et al., 1990a; Bukry, unpubl. data, 1990; Bukry, 1991) and by Rio et al. (1990b) in the Mediterranean.

\section{Zone CNII}

The LO of R pseudoumbilicus, which defines the boundary of Zones CN12-CN11 (NN16-NN15), represents an easily recognized event at all the sites investigated except Site 845, where part of the Pliocene interval contains no nannofossils. To recognize this boundary, we refer to the taxonomic concept of $R$. pseudoumbilicus as expressed by Raffi and Rio (1979) and Backman and Shackleton (1983), and we consider the final exit of the large specimens of $R$. pseudoumbilicus $(>7 \mu \mathrm{m})$. This event occurs in the upper part of Chron $2 \mathrm{Ar}$ (late Gilbert Chron) at Sites 848, 851, 852, and 853, as it does in many other areas (Rio, 1982; Backman and Shackleton, 1983; Rio et al., 1990a, 1990b).

Boundary $\mathrm{CN} 11 \mathrm{~b} / \mathrm{CN} 11 \mathrm{a}$ is defined by the beginning of the common and continuous occurrence of $D$. asymmetricus, a species that has a generally scattered distribution in the upper Miocene of the eastern equatorial Pacific, as well as other oceanic regions (Bukry, 1973), such as the western Indian Ocean (Roth, 1974; Rio et al., 1990 b). Following Okada and Bukry's zonation, the D. asymmetricus event occurs above the LO of Amaurolithus primus and Amaurolithus tricorniculatus, which defines the boundary between Zones CN11 and $\mathrm{CN} 10$. In the lower Pliocene section of the eastern equatorial Pacific, the recognition of these two events has been hampered in some sequences because of (1) the low abundance of the two markers, (2) preservation problems, and (3) sediment reworking, which is particularly evident at western transect Sites 852 and 853 . The continuous presence of $D$. asymmetricus and the disappearance of $A$. primus have been recognized at Sites $846,847,848,851,852$, and 853; generally, the events are close each other.

Regarding the extinction datums of some ceratolithids species, such as representatives of the genus Amaurolithus (A. primus, A. delicatus, and A.tricorniculatus) and $C$. acutus, note that data from various authors (see Berggren et al., 1985) show some discrepancy in the age estimates for these events. The discrepancy may be attributed to a poorly documented extinction pattern of these ceratolithids and/ or from usage of different criteria when identifying the species. Misidentification occurs in samples that contain nannofossils with calcite overgrowth and when specimens of different Amaurolithus and Ceratolithus species possess intergrade morphologic features. This is the case in most of the lower Pliocene sequences recovered during Leg 138. Ceratolithid species are irregularly distributed and are not easily differentiated because of the presence of overgrowth and intergrade morphotypes. Furthermore, at sites where ceratolithids are common and well preserved in the lower Pliocene interval (as at Sites 851, 852, and 853 ), it was not possible to obtain well-documented extinction patterns because of mixing in nannofossil assemblages caused by strong reworking of upper Miocene sediments.

The presence of Discoaster tristellifer within Zone CN11 is noteworthy because it is particularly common in the interval corresponding to the lower range of $D$. asymmetricus.

\section{Zone CN10 (Zones NN13, pars-NN12)}

Boundary $\mathrm{CN} 10 \mathrm{c} / \mathrm{CN} 10 \mathrm{~b}(\mathrm{NN} 12 / \mathrm{NN} 13)$ is defined by the $\mathrm{FO}$ of Ceratolithus rugosus. This boundary is recognized at the first appearance of rare but typical specimens of $C$. rugosus, although the presence of forms intergrading between $C$. rugosus and its ancestor Ceratolithus acutus sometimes makes the recognition of the event difficult. This difficulty may explain the different position of the $C$. rugosus event with respect to Subchron $3 n .4 n$ (Thvera). In Site 852, the FO 
Table 9. Position of calcareous nannofossil events at Hole 850B.

\begin{tabular}{|c|c|c|}
\hline Event & $\begin{array}{c}\text { Interval } \\
(\mathrm{cm})\end{array}$ & $\begin{array}{l}\text { Depth } \\
\text { (mcd) }\end{array}$ \\
\hline T Pseudoemiliania lacunosa & IH- $4,120 / 1 \mathrm{H}-5,63$ & $8.70-9.63$ \\
\hline Reentrance medium Gephyrocapsa spp. & $2 \mathrm{H}-4,41 / 2 \mathrm{H}-4,120$ & $19.31-20.11$ \\
\hline T large Gephyrocapsa spp. & $3 \mathrm{H}-1,120 / 3 \mathrm{H}-2,54$ & $24.85-25.69$ \\
\hline B large Gephyrocapsa spp. & $3 \mathrm{H}-3,120 / 3 \mathrm{H}-4,54$ & $27.85-28.69$ \\
\hline T Calcidiscus macintyrei & $3 \mathrm{H}-5,120 / 3 \mathrm{H}-6,62$ & $30.80-31.77$ \\
\hline B medium Gephyrocapsa spp. & $3 \mathrm{H}-\mathrm{CC} / 4 \mathrm{H}-1,51$ & $33.39-36.36$ \\
\hline T Discoaster brouweri & $4 \mathrm{H}-5,50 / 4 \mathrm{H}-5,65$ & $42.45-42.60$ \\
\hline T Discoaster surculus & $5 \mathrm{H}-6,20 / 5 \mathrm{H}-7,65$ & $53.10-55.05$ \\
\hline T Discoaster tamalis & $6 \mathrm{H}-1,20 / 6 \mathrm{H}-1,65$ & $56.20-56.65$ \\
\hline T Sphenolithus spp. & $7 \mathrm{H}-\mathrm{CC} / 8 \mathrm{H}-1,60$ & $76.66-77.85$ \\
\hline T Reticulofenestra pseudoumbilicus & $8 \mathrm{H}-2,80 / 8 \mathrm{H}-2,100$ & $79.55-79.75$ \\
\hline T Amaurolithus primus (?) & $10 \mathrm{H}-1,59 / 10 \mathrm{H}-6,150$ & $96.84-105.23$ \\
\hline T Ceratolithus acutus (?) & $11 \mathrm{X}-\mathrm{CC} / 12 \mathrm{X}-1,70$ & $114.65-115.95$ \\
\hline B Ceratolithus rugosus & $12 X-1,70 / 12 X-2,120$ & $115.95-116.45$ \\
\hline B Ceratolithus acutus & $13 X-4,120 / 13 X-5,60$ & $130.55-131.45$ \\
\hline T Discoaster quinqueramus & $14 X-7,30 / 15 X-1,35$ & $144.10-144.50$ \\
\hline T Amaurolithus amplificus & $17 \mathrm{X}-6,58 / 18 \mathrm{X}-1,42$ & $171.00-173.17$ \\
\hline $\mathrm{T}$ circular reticulofenestrids & $19 \times-3,60 / 19 X-4,60$ & $185.55-187.05$ \\
\hline B Amaurolithus amplificus & $19 \times-6,60 / 19 X-7,34$ & $190.05-191.29$ \\
\hline T absence interval $R$. pseudoumbilicus & $20 \times-7,43 / 21 \times-1.60$ & $201.28-201.85$ \\
\hline B circular reticulofenestrids & $23 \mathrm{X}-6,61 / 23 \mathrm{X}-7,20$ & $227.84-228.95$ \\
\hline B Amaurolithus primus & $23 \mathrm{X}-7,20 / 24 \mathrm{X}-1,61$ & $228.95-230.86$ \\
\hline B Discoaster berggrenii & $26 \mathrm{X}-3,58 / 26 \mathrm{X}-4,60$ & $253.13-254.65$ \\
\hline B Discoaster loeblichii & $29 \times-6,55 / 29 \times-7,31$ & $286.10-287.36$ \\
\hline B absence interval $R$. pseudoumbilicus & $30 X-3,60 / 30 \times-4,60$ & $300.92-302.42$ \\
\hline T Discoaster hamatus & $33 \mathrm{X}-2,60 / 33 \mathrm{X}-3,60$ & $318.75-320.25$ \\
\hline B Discoaster neohamatus & $33 \mathrm{X}-2,60 / 33 \mathrm{X}-3,60$ & $318.75-320.25$ \\
\hline B Minvlitha convallis & $33 \mathrm{X}-3,60 / 33 \times-4,14$ & $320.25-321.29$ \\
\hline B Discoaster hamatus & $36 \mathrm{X}-5,47 / 36 \mathrm{X}-\mathrm{CC}$ & $352.05-352.42$ \\
\hline T Coccolithus miopelagicus & $37 \mathrm{X}-1,60 / 37 \mathrm{X}-2,61$ & $355.85-357.36$ \\
\hline T c Discoaster kugleri & $40 \times-7,20 / 41 \times-1,60$ & $393.35-394.45$ \\
\hline
\end{tabular}

Note: See note to Table 3 .

of Ceratolithus rugosus is recorded above the Thvera (in Subchron 3n. $3 r$ ); whereas in Sites 848 and 853, it apparently occurs within the Thvera. In this same position, the event was detected by Backman and Shackleton (1983) in the central equatorial Pacific, and by Rio et al. $(1990 \mathrm{a})$ in the western equatorial Indian Ocean. In some sections (Sites $846,848,850$, and 853 ), we detected an overlap of $C$. rugosus with specimens of $C$. acutus. Although this observation agrees with that made by Rio et al. (1990a), most authors (see Berggren et al., 1985) do not report such an overlap.

The first appearance of C. acutus corresponds to the CN10b/ CN10a boundary, as defined by Bukry (1973) together with the LO of Triquetrorhabdulus rugosus. Bukry noted that Subzone CN10a is of very short duration and can easily go undetected in sections with compressed sedimentation rates. In the Leg 138 sections, the FO of C. acutus has been consistently recorded at all sites. It occurs simultaneously with the extinctions of $T$. rugosus and $T$. rioensis at those sites where the two triquetrorhabdulids are present. We note that, in the Leg 138 sections, triquetrorhabdulids are generally rare in their final range, and have a discontinuous distribution within their range, from the middle Miocene upward.

The Subzone CN10a represents the best approximation for the recognition of the Miocene/Pliocene boundary by means of calcareous nannofossils.

\section{Miocene}

The zonal boundaries of the Miocene, as defined by Martini (1971) and Bukry (1973), have been recognized at all sites, with two exceptions: (1) the base of Zone CN6 (NN8) at western transect Sites 849 and 850; and (2) the top of CN7 (NN9) at eastern transect Site 845. In the upper Miocene, supplementary biostratigraphic events allow us to divide the rather long time interval (about $1.7 \mathrm{~m} . \mathrm{y}$.) corresponding to Subzone CN9b. Subzones CN7a-CN7b could not be differentiated.

\section{Zone CN9 (NN11)}

This zone is defined by the total range of the two related taxa Discoaster quinqueramus and Discoaster berggrenii. The LO of $D$.

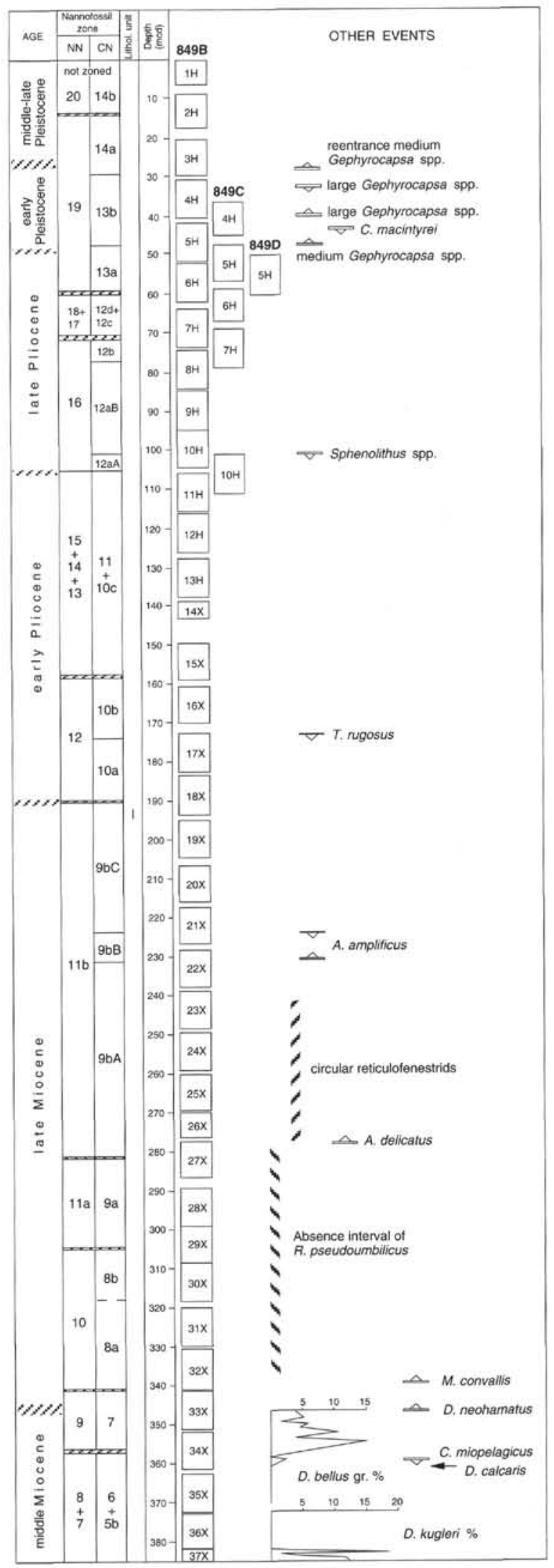

Figure 8. Chronostratigraphy and calcareous nannofossil biostratigraphy at Site 849. Notation as specified in Figure 5. 


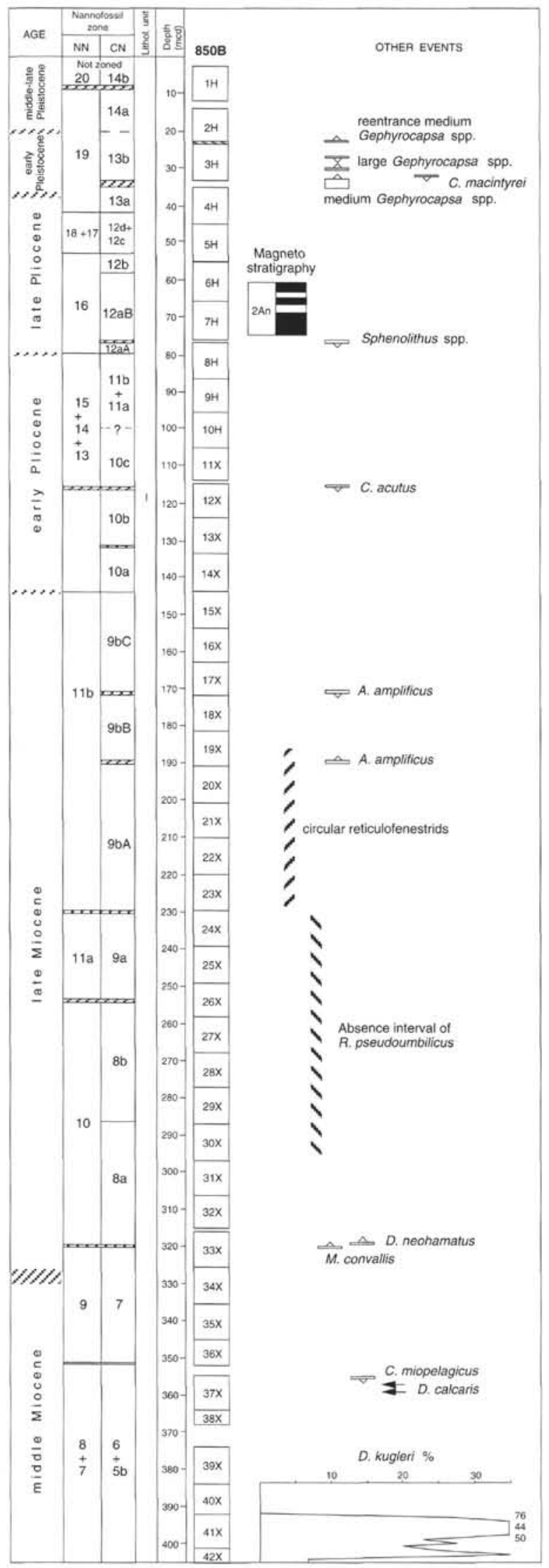

Figure 9. Chronostratigraphy and calcareous nannofossil biostratigraphy at Site 850. Notation as specified in Figure 5. quinqueramus is used to mark the top of Zones CN9 and NN11, as D. berggrenii becomes extinct before D. quinqueramus (Bukry, 1973; Rio et al., 1990a). In our sections, the LO of D. quinqueramus was easily detected; it follows the extinction of $D$. berggrenii, as it does in other regions.

Boundary $\mathrm{CN} 9 \mathrm{~b} / \mathrm{CN} 9 \mathrm{a}$ is defined by the entrance in the stratigraphic record of the genus Amaurolithus, namely, by the FO of A. primus. Although ceratoliths are generally rare, their appearance at the base of Subzone CN9b was easily detected. The earlier forms, belonging to A. primus (see "Taxonomic Notes" section, this chapter), evolved rapidly, leading to the appearance of $A$. delicatus (which occurs shortly after the FO of $A$. primus). Intergrading forms between the two species are frequently found. Amaurolithus tricorniculatus, often recorded as appearing in Subzone CN9b (i.e., Berggren et al., 1985), is very rare and scattered in the material studied. Another species, A. amplificus, occurs after the FO of A. delicatus. The presence of intergrade forms between Triquetrorhabdulus extensus- $T$. rugosus and $A$. amplificus just below the appearance level of $A$. amplificus possibly proves the phylogenetic relationship between Triquetrorhabdulus and Amaurolithus previously suggested by other authors (Gartner, 1967; Perch-Nielsen, 1977, 1985).

The same observations on the A. amplificus distribution pattern have been made in the western equatorial Indian Ocean in Leg 115 successions (Rio et al., 1990a). In the eastern equatorial Pacific, $A$. amplificus becomes extinct within the upper part of Subzone CN9b, in agreement with the previous findings of Bergen (1984) and Rio et al. (1990a). Compared to the Leg 138 paleomagnetic stratigraphy, the FOs and LOs of A. amplificus occur at the base and the top of Chron $3 \mathrm{An}$, respectively, and turn out to be isochronous events with records from the western equatorial Indian Ocean (Rio et al., 1990a). The stratigraphic relationship of the lowest and highest occurrences of $A$. amplificus relative to the lowest occurrence of $A$. primus and the highest occurrence of $D$. quinqueramus allows us to divide the Okada and Bukry (1980) Subzone CN9b further, as suggested by Rio et al. (1990a). We can use these additional events to divide Subzone CN9b into three biostratigraphic units, defined as follows:

CN9bA: from the FO of A. primus to the FO of A. amplificus; CN9bB: from the FO of A. amplificus to the LO of A. amplificus; and

CN9bC: from the LO of A. amplificus to the LO of D. quinqueramus.

The definitions and occurrences of these three new biostratigraphic units are given in Appendix B in addition to any related remarks.

Within Subzone CN9b, the discoasterids are represented by several species, mainly $D$. quinqueramus, D. berggreni, $D$. surculus, and D. pentaradiatus. We note that in all $\mathrm{CN} 9$ zonal intervals, discoasterids fluctuate in abundance and their preservation varies widely in the different successions, sometimes preventing a precise identification of marker and secondary species. Following Rio et al. (1990a), we searched for a large form of Discoaster aff. brouweri (tabulated in Leg 115 range charts as Discoaster sp. 2), which seems to have a restricted stratigraphic distribution within the lower part of $\mathrm{CN} 9 \mathrm{~b}$ and the upper part of CN9a in the western equatorial Indian Ocean. In our cores, this discoasterid does not give the same clear biostratigraphic signal as in the Indian Ocean.

Regarding the $\mathrm{CN} 9 \mathrm{a}$ and NN1la subzones, we use the appearance of $D$. berggrenii to define their lower boundary, as indicated by Bukry (1973). In fact, the $D$. berggrenii morphotypes (the five-rayed discoasterids with a stellar knob in a distinct central area; Plate 2, Figs. 1-2) appeared slightly earlier than $D$. quinqueramus morphotypes sensu Bukry (1971) (Plate 2, Figs. 4-5). Although it is useful to distinguish them for biostratigraphic purposes, D. berggrenii and $D$. quinqueramus have been considered as a single taxonomic unit in the range charts, as intergrades between them are common (Plate 2, Fig. 3). In the eastern equatorial Pacific, the appearance of $D$. berggrenii occurs 


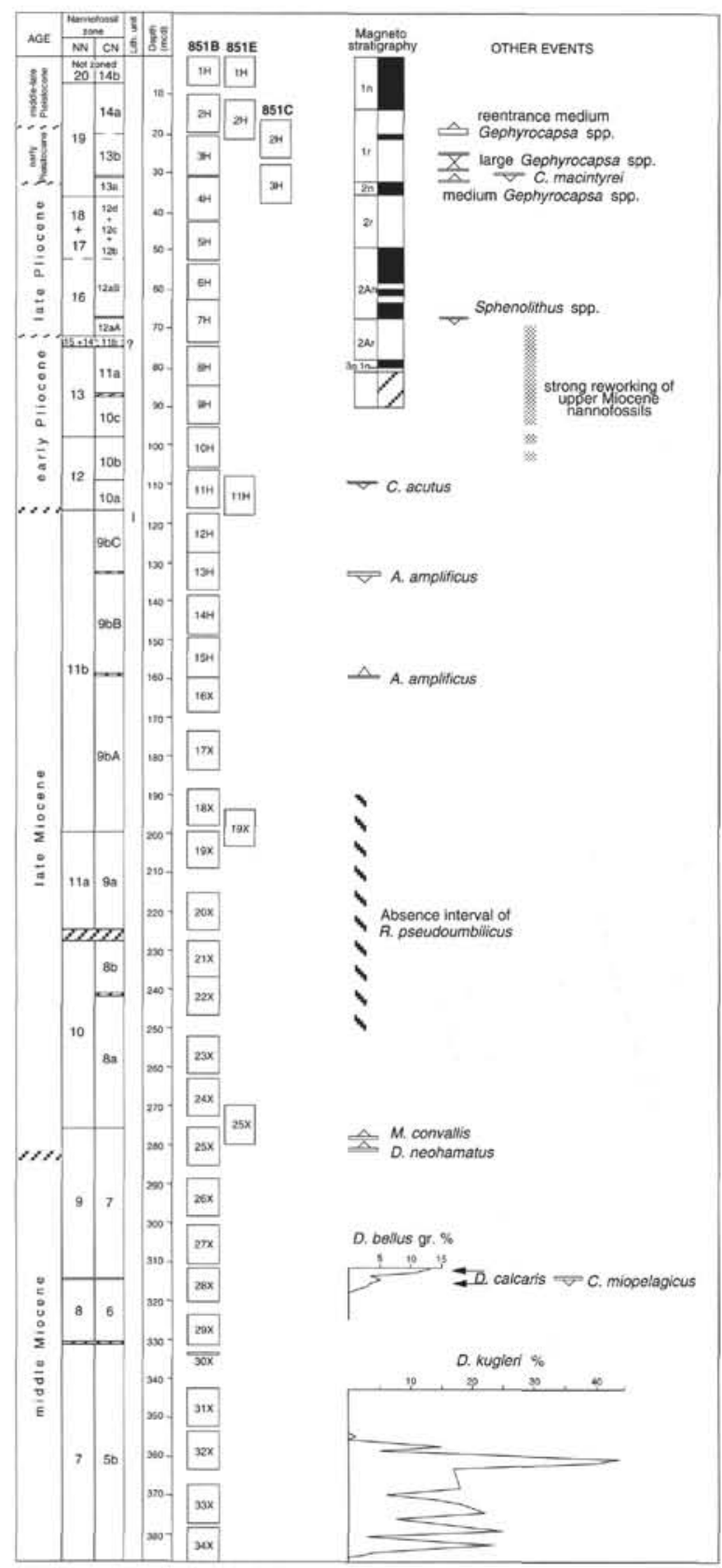

Figure 10. Chronostratigraphy and calcareous nannofossil biostratigraphy at Site 851. Notation as specified in Figure 3.

in the lowermost part of Chron $4 r$ (Subchron 4r.2r), and it is isochronous with the western equatorial Indian Ocean (Rio et al., 1990a). The morphological development of $D$. berggrenii and $D$. quinqueramus was gradual; these discoasterids probably evolved from other five-rayed forms that belong to the D. bellus group (Bukry, 1973), and intergrades between the two discoasterid groups are common.

Within Subzone CN9a, we record the occurrence, but in low abundance, of $D$. pentaradiatus and $D$. surculus. Typical $D$. bellus and Minylitha convallis, present in the underlying intervals, disappear in the upper part of this subzone, whereas the rare $D$. neohamatus, $D$. prepentaradiatus, and $D$. loeblichii have their LOs in the lower part. Similar co-occurrences of $D$. loeblichii and $D$. berggrenii have been noted previously by Rio et al. (1990b) in the western equatorial Indian Ocean, and by Proto-Decima et al. (1978), Mazzei et al. (1979), and Parker et al. (1985) in the Atlantic Ocean.

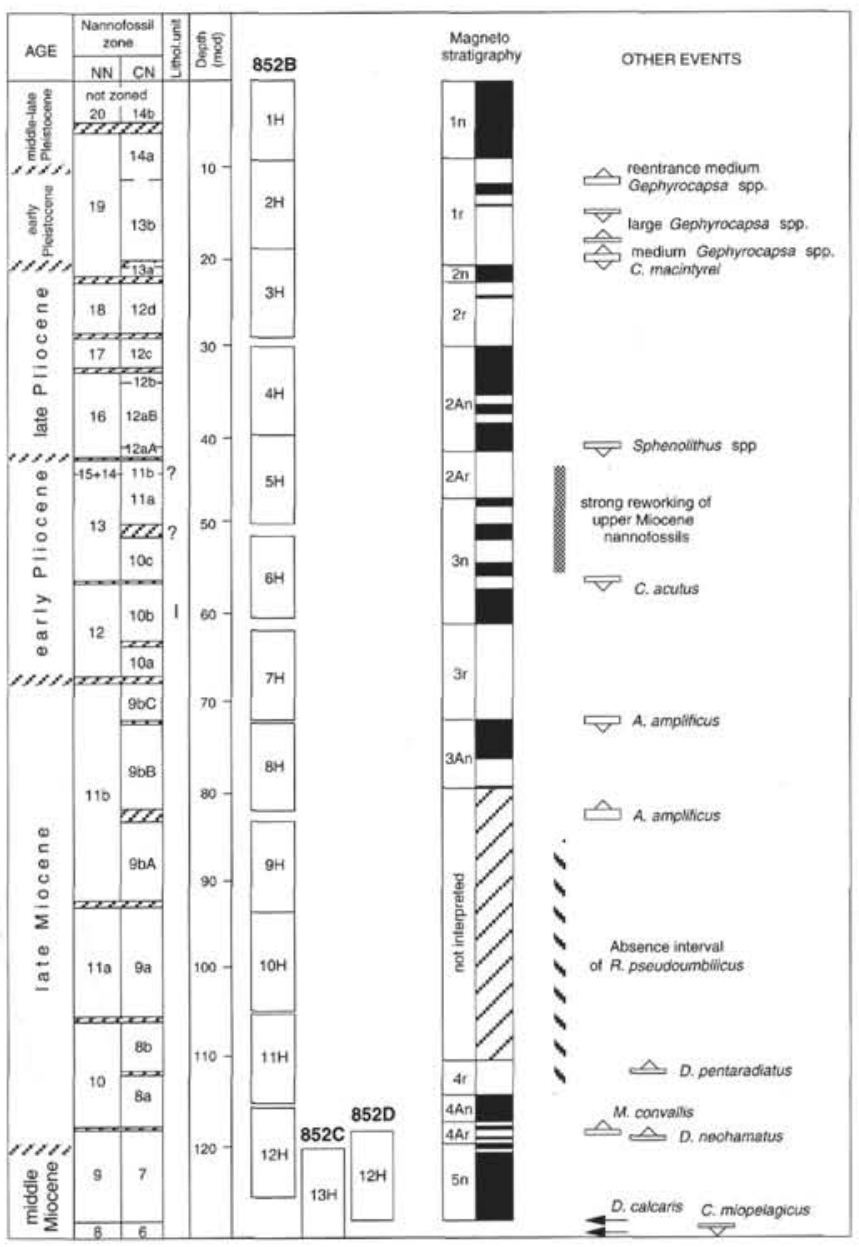

Figure 11. Chronostratigraphy and calcareous nannofossil biostratigraphy at Site 852. Notation as specified in Figure 3.

\section{Zone CN8 (NN10)}

The upper part of this biostratigraphic interval is characterized by the presence of Discoaster loeblichii, used by Bukry (1973), together with $D$. neorectus, as a marker for dividing Zone CN8 into Subzones $\mathrm{CN} 8 \mathrm{~b}$ and CN8a. D. loeblichii was recorded with great consistency in almost all Leg 138 sections, except those where the scarcity and/or poor preservation prevented recognition. At Sites 844, 846, 849, 850, 851,852 , and 853 , we differentiate the two subzones, although $D$. neorectus was found only sporadically.

Close to the FO of D. loeblichii, we observed the lowest specimens of $D$. pentaradiatus. Other components of the discoasterid assemblage of CN8 are abundant or common (e.g., D. brouweri and D. bellus gr.) and scarce (D. neohamatus). In the lower part of the zone, where $D$. bellus gr. dominates, $D$. prepentaradiatus and $D$. calcaris are present in low abundances.

The lower boundary of Zone CN8 is defined by the LO of Discoaster hamatus. This form is generally rare in the uppermost part of the range; however, the event can be consistently recognized in Leg 138 material, with the exception of Site 845 , where the corresponding stratigraphic interval is barren of nannofossils.

Just above the extinction of $D$. hamatus, the FO of $M$. convallis is recorded. This event can be used to recognize the boundary between Zones CN8/CN7 when D. hamatus is too rare (Rio et al., 1990a). In the Leg 138 material, the range of $M$. convallis, which encompasses Zones CN8 and CN9a, shows variability. At the eastern transect sites, the species is generally rare and occurs sporadically, whereas it is continuously present at other sites. This irregular distribution of $M$. 
Table 10. Position of calcareous nannofossil events at Site 853.

\begin{tabular}{|c|c|c|}
\hline Event & $\begin{array}{c}\text { Interval } \\
(\mathrm{cm})\end{array}$ & $\begin{array}{l}\text { Depth } \\
\text { (mcd) }\end{array}$ \\
\hline T Pseudoemiliania lacunosa & $851 \mathrm{~B}-1 \mathrm{H}-5,95 / 1 \mathrm{H}-5,140$ & $6.95-7.40$ \\
\hline Reentrance medium Gephyrocapsa spp. & $85 \mathrm{IE}-2 \mathrm{H}-5,15 / 2 \mathrm{H}-5,45$ & $19.15-19.45$ \\
\hline T large Gephyrocapsa spp. & $85 \mathrm{IC}-2 \mathrm{H}-6,25 / 2 \mathrm{H}-6,70$ & $23.75-24.20$ \\
\hline B large Gephyrocapsa spp. & $851 \mathrm{~B}-3 \mathrm{H}-5,30 / 3 \mathrm{H}-5,60$ & $27.45-27.75$ \\
\hline T Calcidiscus macintyrei & $851 \mathrm{~B}-3 \mathrm{H}-6,100 / 3 \mathrm{H}-7,46$ & $29.65-30.61$ \\
\hline B medium Gephyrocapsa spp. & $851 \mathrm{C}-3 \mathrm{H}-3,70 / 3 \mathrm{H}-3,140$ & $31.25-31.95$ \\
\hline T Discoaster brouweri & $851 \mathrm{~B}-4 \mathrm{H}-3,100 / 4 \mathrm{H}-3,150$ & $35.90-36.40$ \\
\hline T Discoaster surculus & $85 \mathrm{IB}-5 \mathrm{H}-7,65 / 5 \mathrm{H}-\mathrm{CC}$ & $51.95-52.19$ \\
\hline T Discoaster tamalis & $851 \mathrm{~B}-5 \mathrm{H}-7,65 / 5 \mathrm{H}-\mathrm{CC}$ & $51.95-52.19$ \\
\hline T Sphenolithus spp. & $851 \mathrm{~B}-7 \mathrm{H}-3,58 / 7 \mathrm{H}-4,60$ & $67.03-68.55$ \\
\hline T Reticulofenestra pseudoumbilicus & 85 IB- $7 \mathrm{H}-6,25 / 7 \mathrm{H}-6,60$ & $71.20-71.55$ \\
\hline B c Discoaster asymmetricus (?) & $851 \mathrm{~B}-7 \mathrm{H}-7,45 / 8 \mathrm{H}-1,60$ & $72.90-75.00$ \\
\hline T Amaurolithus primus & $851 \mathrm{~B}-09 \mathrm{H}-2,60 / 9 \mathrm{H}-3,60$ & $86.50-88.00$ \\
\hline B Ceratolithus rugosus & $851 \mathrm{~B}-10 \mathrm{H}-2,25 / 10 \mathrm{H}-2,60$ & $97.20-97.55$ \\
\hline T Ceratolithus acutus & $851 \mathrm{~B}-10 \mathrm{H}-2,25 / 10 \mathrm{H}-2,60$ & $97.20-97.55$ \\
\hline B Ceratolithus acutus & $851 \mathrm{~B}-11 \mathrm{H}-2,60 / 11 \mathrm{H}-2,110$ & $108.25-108.75$ \\
\hline T Discoaster quinqueramus & $851 \mathrm{E}-11 \mathrm{H}-6,44 / 11 \mathrm{H}-6,90$ & $116.24-116.70$ \\
\hline T Amaurolithus amplificus & $851 \mathrm{~B}-13 \mathrm{H}-3,68 / 13 \mathrm{H}-4,70$ & $131.48-133.00$ \\
\hline B Amaurolithus amplificus & $851 \mathrm{~B}-15 \mathrm{H}-6,69 / 15 \mathrm{H}-7,63$ & $157.54-158.98$ \\
\hline T absence interval $R$. pseudoumbilicus & $851 \mathrm{~B}-18 \mathrm{X}-2,60 / 18 \mathrm{X}-3,60$ & $190.35-191.85$ \\
\hline B Amaurolithus primus & $851 \mathrm{E}-19 \mathrm{X}-4,25 / 19 \mathrm{X}-4,60$ & $199.25-199.60$ \\
\hline T Minylitha convallis & $851 \mathrm{~B}-19 \mathrm{X}-1,25 / 19 \mathrm{X}-1,58$ & $199.40-199.68$ \\
\hline B Discoaster berggrenii & $851 \mathrm{~B}-20 \mathrm{X}-\mathrm{CC} / 21 \mathrm{X}-1,25$ & $224.88-227.90$ \\
\hline B Discoaster loeblichii & $851 \mathrm{~B}-22 \mathrm{X}-3,60 / 22 \mathrm{X}-4,60$ & $240.45-241.95$ \\
\hline B absence interval $R$. pseudoumbilicus & $851 \mathrm{~B}-22 \mathrm{X}-7,31 / 23 \mathrm{X}-1,60$ & $246.16-252.65$ \\
\hline T Discoaster hamatus & $851 \mathrm{E}-25 \mathrm{X}-4,25 / 25 \mathrm{X}-4,56$ & $275.05-275.36$ \\
\hline B Minylitha convallis & $851 \mathrm{~B}-25 \mathrm{X}-1,60 / 25 \mathrm{X}-2.60$ & $276.10-277.60$ \\
\hline B Discoaster neohamatus & 85 । B- $25 X-4,120 / 25 X-5,60$ & $281.20-282.10$ \\
\hline B Discoaster hamatus & 85 ।B- $28 X-2,140 / 28 X-3,40$ & $314.30-314.8$ \\
\hline T Coccolithus miopelagicus & $851 \mathrm{~B}-28 \mathrm{X}-3,40 / 28 \mathrm{X}-3,80$ & $314.80-315.20$ \\
\hline B Catinaster coalitus & $851 \mathrm{~B}-29 \mathrm{X}-5,71 / 29 \mathrm{X}-\mathrm{CC}$ & $330.21-331.23$ \\
\hline T c Discoaster kugleri & $851 \mathrm{~B}-32 \mathrm{X}-4,55 / 32 \mathrm{X}-4,120$ & $358.80-359.45$ \\
\hline B c Discoaster kugleri (?) & $851 B-34 X-3,120 / 34 X-4.65$ & $382.65-383.60$ \\
\hline
\end{tabular}

Note: See note to Table 3.

Table 11. Position of calcareous nannofossil events at Site 851 .

\begin{tabular}{|c|c|c|}
\hline Event & $\begin{array}{c}\text { Interval } \\
(\mathrm{cm})\end{array}$ & $\begin{array}{l}\text { Depth } \\
\text { (mcd) }\end{array}$ \\
\hline T Pseudoemiliania lacunosa & $852 \mathrm{~B}-\mathrm{IH}-3,110 / 1 \mathrm{H}-4,60$ & $4.30-5.30$ \\
\hline Reentrance medium Gephyrocapsa spp. & $852 \mathrm{~B}-2 \mathrm{H}-2,65 / 2 \mathrm{H}-2,140$ & $11.30-12.05$ \\
\hline T large Gephyrocapsa spp. & $852 \mathrm{~B}-2 \mathrm{H}-4,65 / 2 \mathrm{H}-4,140$ & $14.30-15.05$ \\
\hline B large Gephyrocapsa spp. & $852 \mathrm{~B}-2 \mathrm{H}-6.140 / 2 \mathrm{H}-7,40$ & $18.05-18.55$ \\
\hline T Calcidiscus macintyrei & $852 \mathrm{~B}-3 \mathrm{H}-1,65 / 3 \mathrm{H}-1,140$ & $19.85-20.70$ \\
\hline B medium Gephyrocapsa spp. & $852 \mathrm{~B}-3 \mathrm{H}-1.65 / 3 \mathrm{H}-1.140$ & $19.85-20.70$ \\
\hline T Discoaster brouweri & $852 \mathrm{~B}-3 \mathrm{H}-2,65 / 3 \mathrm{H}-2,140$ & $21.35-22.10$ \\
\hline T Discoaster pentaradiatus & $852 \mathrm{~B}-3 \mathrm{H}-7,35 / 3 \mathrm{H}-\mathrm{CC}$ & $28.55-29.29$ \\
\hline T Discoaster surculus & $852 \mathrm{~B}-4 \mathrm{H}-2,65 / 4 \mathrm{H}-2,140$ & $32.45-33.20$ \\
\hline T Discoaster tamalis & $852 \mathrm{~B}-4 \mathrm{H}-3,65 / 4 \mathrm{H}-3,140$ & $33.95-34.70$ \\
\hline T Sphenolithus spp. & $852 \mathrm{~B}-5 \mathrm{H}-1,80 / 5 \mathrm{H}-1,135$ & $41.05-41.60$ \\
\hline T Reticulofenestra pseudoumbilicus & $852 \mathrm{~B}-5 \mathrm{H}-2,80 / 5 \mathrm{H}-2,140$ & $42.55-43.15$ \\
\hline B c Discoaster asymmetricus (?) & $852 \mathrm{~B}-5 \mathrm{H}-3,30 / 5 \mathrm{H}-3,80$ & $43.55-44.05$ \\
\hline T Amaurolithus primus & $852 \mathrm{~B}-5 \mathrm{H}-7,80 / 6 \mathrm{H}-\mathrm{I}, 80$ & $50.05-52.65$ \\
\hline B Ceratolithus rugosus & $852 \mathrm{~B}-6 \mathrm{H}-3,135 / 6 \mathrm{H}-4,35$ & $56.20-56.70$ \\
\hline T Ceratolithus acutus & $852 \mathrm{~B}-6 \mathrm{H}-4,35 / 6 \mathrm{H}-4.80$ & $56.70-57.15$ \\
\hline B Ceratolithus acutus & $852 \mathrm{~B}-7 \mathrm{H}-1.71 / 7 \mathrm{H}-1,127$ & $62.96-63.52$ \\
\hline T Discoaster quinqueramus & $852 \mathrm{~B}-7 \mathrm{H}-3,75 / 7 \mathrm{H}-3,140$ & $66.00-66.65$ \\
\hline T Amaurolithus amplificus & $852 \mathrm{~B}-7 \mathrm{H}-\mathrm{CC} / 8 \mathrm{H}-1,120$ & $72.21-73.85$ \\
\hline B Amaurolithus amplificus & $852 \mathrm{~B}-8 \mathrm{H}-\mathrm{CC} / 9 \mathrm{H}-\mathrm{I}, 70$ & $82.77-84.60$ \\
\hline T absence interval $R$. pseudoumbilicus & $852 \mathrm{~B}-9 \mathrm{H}-1.70 / 9 \mathrm{H}-2.70$ & $84.60-86.10$ \\
\hline B Amaurolithus primus & $852 \mathrm{~B}-9 \mathrm{H}-6,140 / 9 \mathrm{H}-7,70$ & $92.80-93.60$ \\
\hline B Discoaster berggrenii & $852 \mathrm{~B}-11 \mathrm{H}-1,40 / 11 \mathrm{H}-1,80$ & $105.80-106.20$ \\
\hline B Discoaster pentaradiatus & $852 \mathrm{~B}-11 \mathrm{H}-4,145 / 11 \mathrm{H}-5,40$ & $111.35-111.80$ \\
\hline B Discoaster loeblichii & $852 \mathrm{~B}-11 \mathrm{H}-5,40 / 11 \mathrm{H}-5,80$ & $111.80-112.20$ \\
\hline B absence interval $R$. pseudoumbilicus & $852 \mathrm{~B}-11 \mathrm{H}-6,140 / 11 \mathrm{H}-7,83$ & $114.30-115.23$ \\
\hline B Minylitha convallis & $852 \mathrm{~B}-12 \mathrm{H}-2,70 / 12 \mathrm{H}-2,110$ & $118.30-118.70$ \\
\hline T Discoaster hamatus & $852 \mathrm{~B}-12 \mathrm{H}-2,70 / 12 \mathrm{H}-2,110$ & $118.30-118.70$ \\
\hline B Discoaster neohamatus & $852 \mathrm{~B}-12 \mathrm{H}-2,120 / 12 \mathrm{H}-3,143$ & $118.80-119.03$ \\
\hline B Discoaster hamatus & $852 C-13 X-6,40 / 13 X-6,50$ & $128.80-128.90$ \\
\hline T Coccolithus miopelagicus & $852 \mathrm{C}-13 \mathrm{X}-6,50 / 13 \mathrm{X}-6,90$ & $128.90-129.30$ \\
\hline
\end{tabular}

Note: See note to Table 3.

convallis seems to be influenced by variability in either the preservation of nannofossil assemblages or the productivity conditions, in that the form is rare and discontinuous at sites influenced by upwelling (i.e., 844 and 845 ).

A feature of the nannofossil assemblage of Zone CN8 is the turnover detected within the placolith group, namely, an almost total dis- appearance of large specimens ( $>7 \mu \mathrm{m}$ ) of Reticulofenestra pseudoumbilicus. This placolith enters the stratigraphic record in the middle Miocene, close to the top of Zone CN4 (NN5), and exits in the middle part of the Pliocene. The interval of absence of $R$. pseudoumbilicus, recorded in all the stratigraphic successions of Leg 138, starts from the lower upper Miocene (Zones CN8-NN10) and extends to the 
Table 12. Position of calcareous nannofossil events at Site 853.

\begin{tabular}{|c|c|c|}
\hline Event & $\begin{array}{c}\text { Interval } \\
(\mathrm{cm})\end{array}$ & $\begin{array}{l}\text { Depth } \\
\text { (mcd) }\end{array}$ \\
\hline T Pseudoemiliania lacunosa & $853 \mathrm{~B}-1 \mathrm{H}-2,120 / 1 \mathrm{H}-2,130$ & $2.70-2.80$ \\
\hline Reentrance medium Gephyrocapsa spp. & $853 \mathrm{~B}-1 \mathrm{H}-3,80 / 1 \mathrm{H}-\mathrm{CC}$ & $3.80-4.25$ \\
\hline B large Gephyrocapsa spp. & $853 \mathrm{~B}-2 \mathrm{H}-1,120 / 2 \mathrm{H}-2,65$ & $5.45-6.40$ \\
\hline T Calcidiscus macintyrei & $853 \mathrm{~B}-2 \mathrm{H}-2,65 / 2 \mathrm{H}-2,120$ & $6.40-6.95$ \\
\hline B medium Gephyrocapsa spp. & $853 \mathrm{~B}-2 \mathrm{H}-2,140 / 2 \mathrm{H}-3,25$ & $7.15-7.50$ \\
\hline T Discoaster brouweri & $853 \mathrm{~B}-2 \mathrm{H}-3,25 / 2 \mathrm{H}-3,65$ & $7.50-7.90$ \\
\hline T Discoaster pentaradiatus & $853 \mathrm{~B}-2 \mathrm{H}-5,65 / 2 \mathrm{H}-5,120$ & $10.90-11.45$ \\
\hline T Discoaster surculus & $853 \mathrm{~B}-2 \mathrm{H}-6,120 / 2 \mathrm{H}-6,140$ & $12.95-13.15$ \\
\hline T Discoaster tamalis & $853 \mathrm{~B}-2 \mathrm{H}-7,30 / 3 \mathrm{H}-1,65$ & $13.55-15.35$ \\
\hline T Sphenolithus spp. & $853 \mathrm{~B}-3 \mathrm{H}-4,120 / 3 \mathrm{H}-4,140$ & $20.40-20.60$ \\
\hline T Reticulofenestra pseudoumbilicus & $853 \mathrm{~B}-3 \mathrm{H}-4,120 / 3 \mathrm{H}-4,140$ & $20.40-20.60$ \\
\hline B c Discoaster asymmetricus & $853 \mathrm{~B}-4 \mathrm{H}-1,65 / 4 \mathrm{H}-2,65$ & $21.95-23.45$ \\
\hline T Amaurolithus primus & $853 \mathrm{~B}-4 \mathrm{H}-3,140 / 4 \mathrm{H}-4,25$ & $25.70-26.05$ \\
\hline T Ceratolithus acutus & $853 \mathrm{~B}-4 \mathrm{H}-5,140 / 4 \mathrm{H}-6,80$ & $28.70-29.60$ \\
\hline B Ceratolithus rugosus & $853 \mathrm{~B}-4 \mathrm{H}-6,80 / 4 \mathrm{H}-\mathrm{CC}$ & $29.60-29.89$ \\
\hline B Ceratolithus acutus & $853 \mathrm{~B}-5 \mathrm{H}-1,65 / 5 \mathrm{H}-1,120$ & $32.40-32.95$ \\
\hline T Discoaster quinqueramus & $853 \mathrm{~B}-5 \mathrm{H}-1,65 / 5 \mathrm{H}-1,120$ & $32.40-32.95$ \\
\hline T Amaurolithus amplificus & $853 \mathrm{~B}-5 \mathrm{H}-5,65 / 5 \mathrm{H}-5,120$ & $38.40-38.95$ \\
\hline B Amaurolithus amplificus & $853 \mathrm{~B}-6 \mathrm{H}-4,27 / 6 \mathrm{H}-4,65$ & $46.37-46.75$ \\
\hline T absence interval $R$. pseudoumbilicus & $853 \mathrm{~B}-6 \mathrm{H}-5,65 / 6 \mathrm{H}-6,65$ & $48.25-49.75$ \\
\hline B Amaurolithus primus & $853 \mathrm{~B}-7 \mathrm{H}-2,147 / 7 \mathrm{H}-3,30$ & $54.42-54.75$ \\
\hline B Discoaster berggrenii & $853 \mathrm{D}-7 \mathrm{H}-4,120 / 7 \mathrm{H}-4,140$ & $69.47-69.67$ \\
\hline
\end{tabular}

Note: See note to Table 3.

lower part of Subzone CN9b. The bottom of this interval is characterized by the absence of all the representatives of genus Reticulofenestra, including the small $(\leq 7 \mu \mathrm{m})$ morphotypes; large forms of $R$. pseudoumbilicus reenter, with low abundance, just below the appearance level of $A$. amplificus. This temporary disappearance has also been observed in the western equatorial Indian Ocean (Young, 1990; Rio et al., 1990a), and was interpreted as a regional stratigraphic feature, probably reflecting oceanographic-climatic instability (Rio et al., 1990a). Indications of the wider geographical extent of this "feature" in the $R$. pseudoumbilicus range are reported and discussed in Raffi et al. (this volume).

\section{Zone CN7 (NN9)}

The total range of Discoaster hamatus defines the CN7 (NN9) zonal interval. Despite the low abundance of discoasterids at some sites (Sites 846, 849, and 850) and the presence of barren intervals observed at others (Sites 844 and 845), the consistent occurrence of $D$. hamatus allows us to recognize this zonal interval in the material we investigated. Close to the FO of $D$. hamatus, other five-rayed discoasterids appear. They have straight, tapering arms and belong to the Discoaster bellus group. Their presence is useful in monitoring the base of the zone where $D$. hamatus is rare.

We have not divided Zone CN7 into two subzones ("a" and "b"), as suggested by Bukry (1973) on the basis of the first evolutionary appearance of $C$. calyculus from C. coalitus. In fact, in the Leg 138 sections, the genus Catinaster is represented mainly by $C$. coalitus, whereas very rare and scattered specimens of $C$. calyculus have been recorded in intervals below the appearance of $D$. hamatus (i.e., at Sites 844,845 , and 846). This finding agrees with the results from the western equatorial Indian Ocean (Rio et al., 1990a) and with the observation of Perch-Nielsen (1985), who questioned the subdivision of Zone CN7. Within this zone, the $D$. variabilis group and $D$. bollii are common; in the upper part, the last, rare representatives of $D$. exilis disappear, and $D$. neohamatus appears.

\section{Zone CN6 (NN8)}

The short CN6 (NN8) zonal interval is defined by the FO of $D$. hamatus (top) and the FO of $C$. coalitus plus the LO of Discoaster kugleri (bottom). In the material investigated, representatives of Catinaster are irregularly distributed. The zone is clearly recognized at Sites 844,845 , and 851 , where $C$. coalitus is well represented, even

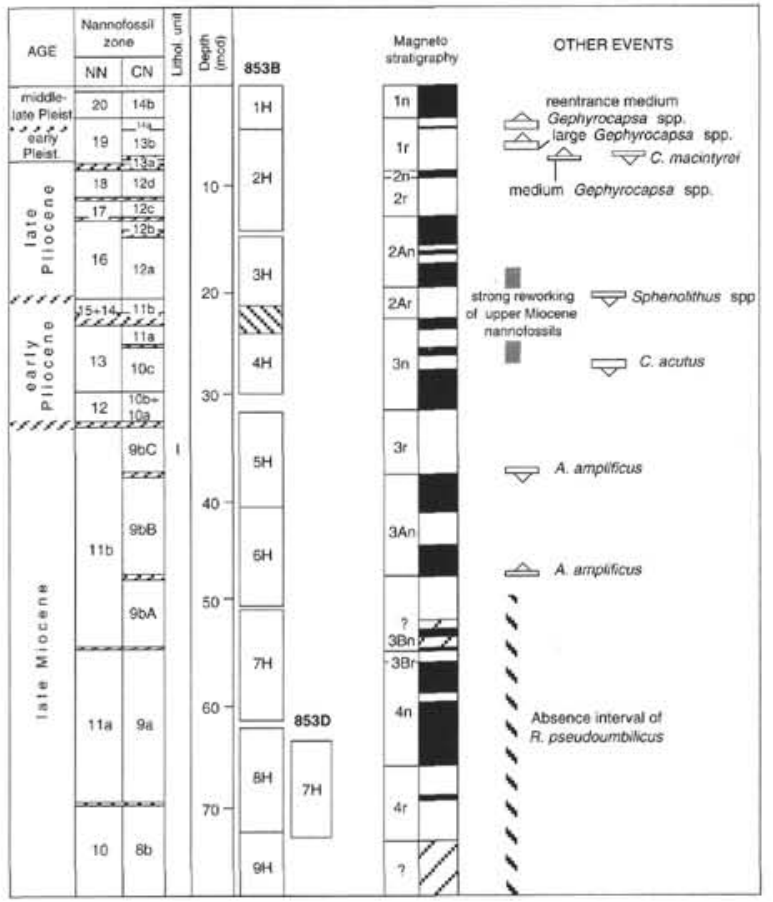

Figure 12. Chronostratigraphy and calcareous nannofossil biostratigraphy at Site 853. Notation as specified in Figure 3.

though C. calyculus is rare and scattered. At Site 846, the marker $C$. coalitus is very rare; and at Sites 849 and 850 , it is found only in the biozone above (CN7). At these sites, fluctuating but low abundances also characterize the distributions of the other discoasterids. We failed to find the rare and scattered last specimens of $D$. kugleri, recorded at Sites 844 and 845 , close to the $C$. coalitus appearance. These generally low abundances of discoasterids have been observed all along the interval encompassing Subzone CN5b (upper part)-CN6-CN7, corresponding to the time interval from 10.8 to $9.5 \mathrm{Ma}$. As already noted at other levels in the upper Miocene (Zone CN9) and Pliocene, highproductivity conditions influence these equatorial successions, the nannofossil content, and discoasterid abundance, as suggested by Chepstow-Lusty et al. (1989, 1992). 
In the upper part of Zone CN6, and across the boundary between Zones CN7/CN6, a turnover in the nannofossil assemblage occurs, mainly within discoasterids. Besides the appearance of $D$. bellus gr., which becomes a dominant species in the overlying intervals, $D$. calcaris has a short and distinctive range. D. exilis declines gradually toward the extinction, and D. brouweri has a more continuous distribution. According to Bukry (1973), we recorded the extinction of Coccolithus miopelagicus within this zone, just below the upper boundary. In the eastern equatorial Pacific, this event seems to occur slightly later than at the mid-latitudes of the northern Atlantic (Olafsson, 1991) (see discussion in Raffi et al., this volume).

We detected a remarkable decline in the preservation state and composition of the nannofossil assemblages at Leg 138 sites in the interval from the top of CN5b to CN7. This interval, which is characterized by reduced sedimentation rates and increased carbonate dissolution, is comparable to other sites in the Pacific (Mayer et al., 1986) and may represent a dissolution event related to a general reorganization of Pacific circulation (Mayer, Pisias, Janecek, et al., 1992).

\section{Zone CN5 (Zones NN7 and NN6)}

The top of this zone is defined by the FO of $C$. coalitus and the LO of Discoaster kugleri. The bottom is defined by the LO of Sphenolithus heteromorphus. The zone spans a rather long time interval, over $2.5 \mathrm{~m}$.y. In addition, Zone CN5 is divided into two subzones (CN5b and CN5a) by the FO of Discoaster kugleri (Bukry, 1973), which also defines the NN7/NN6 zonal boundary. The recognition of this boundary has been debated, as D. kugleri is considered a weak marker by many authors (e.g., Gartner and Chow, 1985; Gartner, 1992; Fornaciari et al., 1990). Substitute events suggested for dividing Zone CN5 are (1) the LO of Cyclicargolithus floridanus, proposed by Bukry (1973) as a secondary marker for the base of Subzone CN5b; (2) the FO of Discoaster bollii, proposed by Ellis (1981); and (3) the LO of Coronocyclus nitescens, proposed by Gartner and Chow (1985). Detailed documentation of these and other events can help to establish more reliable criteria for the definition of Subzones CN5b and CN5a (see discussion in Raffi et al., this volume). Among secondary biostratigraphic markers, Fornaciari et al. (1990) suggested that $C$. nitescens is more useful than $D$. kugleri, which is difficult to recognize in overgrown assemblages and which has a discontinuous distribution. In our sediments, we recorded some of these alternative potential markers, although the FO of $D$. kugleri was recognized and used to place the boundary between Subzones CN5b and CN5a. As expected, only through quantitative analysis on closely spaced samples has it been possible to determine the event precisely. D. kugleri is very rare in the lowermost range and is missing in many intervening samples. The distribution patterns at Sites 844,845 , and 846 (Figs. $3-5$ ) provide evidence for the "appearance" of D. kugleri: (1) a first rare occurrence that is close to the extinction of $C$. nitescens (within Subchron 5An at Site 845) in the Leg 138 successions, as it is in the western equatorial Indian Ocean (Fornaciari et al., 1990); and (2) the beginning of common and continuous distribution, with a restricted stratigraphic extension, occurring at the base of Chron 5 r. This latter event is probably the same event recorded as " $D$. kugleri lowest occurrence" by Gartner (1992) in DSDP Site 608 (North Atlantic), as suggested by the calibration to the magnetostratigraphy. The highest occurrence of $D$. kugleri is reported as occurring close to the appearance of C. coalitus (Bukry, 1973). In the material studied, we observed a clear event of "disappearance" for D. kugleri, which corresponds to the end of its common and continuous distribution and has been recorded in all the sequences that penetrated to Subzone CN5b. At Site 845, this event occurs within Chron 5 r (just above Subchron $5 \mathrm{r} .2 \mathrm{n}$ ). The last specimens of $D$. kugleri, known to disappear close to the appearance of C. coalitus (Bukry, 1973), have been observed only at Sites 844 and 845 as rare and scattered occurrences (Figs. 3-4).

Within Subzone CN5b in the equatorial Indian Ocean, large-sized Calcidiscus $(\geq 11 \mu \mathrm{m})$, labeled as $C$. macintyrei, enter the strati- graphic record (Fornaciari et al., 1990). Detailed analyses performed on Leg 138 material to check this occurrence indicate that $C$. macintyrei is extremely rare and scattered. This species does not provide a useful biostratigraphic signal in this interval.

Within Subzone CN5a, in the middle part of Chron 5Ar at Site 845 , we recorded the FO of Triquetrorhabdulus rugosus. This was recorded at a similar stratigraphic position in the mid-latitude North Atlantic (Olafsson, 1991). The biostratigraphic usefulness of this event has also been shown in the equatorial Atlantic, Pacific, and Indian oceans (Olafsson, 1989; Fornaciari et al., 1990, 1993).

In the lower part of Subzone CN5a, we record the highest occurrence of $C$. floridanus, within Chron 5AAr at Site 845. It is a distinct event that occurs well below the FO of D. kugleri. The final range of C. floridanus has been shown to be biogeographically controlled (Olafsson, 1991; Fornaciari et al., 1993). Therefore, the use of the extinction event of $C$. floridanus for recognizing the base of Subzone CN5b (base of Zone NN7) (Bukry, 1973) may cause confusion when correlating between different regions.

The nannofossil assemblage of Zone CN5 is dominated by helicoliths, placoliths, and sphenoliths. Discoasterids fluctuate in abundance and are generally overgrown. Besides D. kugleri, other groups that are well represented in Subzone $\mathrm{CN} 5$ b include $D$. exilis, $D$. musicus, and D. variabilis. D. bollii and D. brouweri are very rare in Subzone $\mathrm{CN} 5 \mathrm{~b}$ and are scattered in the upper part. D. signus becomes extinct within Subzone CN5a, just below the lowest occurrence of $T$. rugosus. Among the placoliths of CN5, R. pseudoumbilicus $(>7 \mu \mathrm{m})$ is dominant and representatives of genus Calcidiscus occur discontinuously in low abundance. Close to the transition between Subzones $\mathrm{CN} 5 \mathrm{~b} / \mathrm{CN} 5 \mathrm{a}$ (between the highest occurrence of $C$. nitescens and the lowest occurrence of T. rugosus), we observed the extinctions of Triquetrorhabdulus serratus and Calcidiscus premacintyrei. Additional investigations on the distribution of these taxa, and of D. kugleri and C. floridanus, may clarify their stratigraphic relationship and allow further subdivision of Zone CN5, at least on a regional scale.

\section{Zone CN4 (NN5)}

This zone is defined by the LO of Sphenolithus heteromorphus (top) and the FO of Helicosphaera ampliaperta (bottom).The CN5/ $\mathrm{CN} 4$ boundary is characterized by another turnover in the nannofossil assemblage, also documented in the equatorial Indian Ocean (Rio et al., 1990a). Large $R$. pseudoumbilicus, which are dominant in the overlying interval, appears with rare specimens at the transition between $\mathrm{CN} 5$ and $\mathrm{CN} 4$.

The extinction of $S$. heteromorphus is a neat event in the successions studied. It marks the final occurrence of "spined" sphenoliths, which were dominant in the underlying intervals and have been replaced by small forms related to Sphenolithus abies. Helicoliths are common to abundant. In the discoasterid assemblage of Zone CN4, slender-armed forms like $D$. exilis, $D$. variabilis, and $D$. signus are present continuously, whereas the short-armed discoasterids of the Discoaster deflandrei group gradually disappear. Within this stratigraphic interval, the discoasterid assemblage was often strongly overgrown, thus preventing the recognition of the different species of discoasterids.

\section{Zone CN3 (NN4)}

Sediments belonging to this zone were recovered at eastern transect Sites 844,845 , and 846 . The lowermost parts of these sequences fall within Zone $\mathrm{CN} 3$, that is, within the range of $S$. heteromorphus. This biostratigraphy provides the age control for the basement at these sites. The biostratigraphic basement age of 16.5 to $17 \mathrm{~m} . \mathrm{y}$. is older than the age previously estimated by tectonic subsidence or spreading models (Mayer, Pisias, Janecek, et al., 1992).

We used the highest occurrence of Helicosphaera ampliaperta to define the upper boundary of this zone, although Bukry $(1975,1978)$ considered this species a secondary marker, owing to its irregular 
distribution in many oceanic areas. He suggested the use of the appearance of $C$. macintyrei for the definition of the boundary between Zones CN4 and CN3. Moreover, Bukry (1978) "declassed" the end of the $D$. deflandrei acme (not quantitatively defined) as a secondary marker in his zonal scheme. This event was the primary criterion he proposed in 1973 for defining the $\mathrm{CN} 4 / \mathrm{CN} 3$ zonal boundary. In fact, this event can be influenced by variable preservational and ecological factors and may vary from place to place (Bukry, 1978; Parker et al., 1985). In Leg 138 material, H. ampliaperta is rare in the upper part of the range, but its extinction is a rather clear event. Olafsson (1991) demonstrated that the disappearance of $H$. ampliaperta in the mid-latitude North Atlantic is also a distinct event. Interestingly, $H$. ampliaperta is absent in the western equatorial Pacific (Leg 130) (Fornaciari et al., 1993), thus confirming the regional character of this biostratigraphic marker. Other events have been proposed for the definition of boundary CN4/CN3. We have not considered them, such as the lowest occurrence of Bukry's C. macintyrei, as the application of different taxonomic concepts can lead to ambiguous biostratigraphic results (Fornaciari et al., 1990). Regarding the end of the $D$. deflandrei acme, we performed quantitative analyses on the discoasterid assemblages within the upper part of Zone CN3, following Rio et al. (1990a), to obtain the distribution pattern of $D$. deflandrei. Assuming the Rio et al. (1990a) definition for the end of the acme (i.e. a drop below a value of $30 \%$ relative to the total discoasterids), the event occurs before the LO of $H$. ampliaperta in the uppermost $\mathrm{CN} 3$. The $D$. deflandrei event coincides with the lowest occurrence of Discoaster signus (Figs. 3-4). Such concomitant events were detected also in the western equatorial Indian Ocean (Rio et al., 1990a) and were used to distinguish the CN4/CN3 boundary where $H$. ampliaperta was missing.

The nannofossil assemblage of this part of Zone $\mathrm{CN} 3$ is dominated by helicoliths, sphenoliths, and small placoliths as Reticulofenestra spp. and Dictyococcites spp. The distribution pattern of S. heteromorphus is characterized by peaks in abundance at discrete levels, where the species is the dominant component of the nannofossil assemblage.

\section{BIOCHRONOLOGY}

The biochronology adopted in this work is derived from a recalibration of the nannofossil events to the new time scale developed for Leg 138 sites (Shackleton et al., this volume). From 0 to $6 \mathrm{Ma}$, this new time scale is orbitally tuned and provides new ages for the magnetic reversals as well as the biostratigraphic events. Before $6 \mathrm{Ma}$, the Leg 138 time scale is based on the new calibrations obtained in the tuned interval, but it converges with the Cande and Kent (1992) paleomagnetic time scale by $14.8 \mathrm{Ma}$. In Table 2 , we list the calcareous nannofossil events that define the zonal boundaries reported in Figure 2, as well as additional events, together with their assigned age estimates.

The nannofossil biochronology of the Pleistocene and Pliocene is well established, as demonstrated by a number of studies dealing with direct correlations of the events to magnetostratigraphies and highresolution isotope stratigraphies (e.g., Backman and Shackleton, 1983; Berggren et al., 1985; Raffi et al., 1993). Therefore, the biochronologic data on Pleistocene and Pliocene nannofossil events reported in this work are derived from recent literature and from recalibration to an orbitally tuned time scale (Shackleton et al., this volume).

In the Miocene interval, the excellent magnetostratigraphies obtained at Sites $844,845,852$, and 853 in the upper Miocene, and extending to the middle Miocene at Site 845 (see site reports in Mayer, Pisias, Janecek, et al., 1992, and Schneider, this volume), allow us to refine the nannofossil biochronology of this time interval. The resulting biochronology substantially agrees with that obtained in the equatorial Indian Ocean during ODP Leg 115 (Backman et al., 1990; Rio et al., 1990a). Differences between these low-latitude biochronologies include the $\mathrm{B}$ (bottom occurrence of) $C$. coalitus. In the Leg 138 material, this event was directly calibrated to magnetostratigraphy and occurs in the lower part of Chron $5 \mathrm{n} .2 \mathrm{n}$ (age estimate of $10.7 \mathrm{Ma}$ ). It is considerably younger than the date of $11.6 \mathrm{Ma}$ (reestimated) obtained from Site 714 (Backman et al., 1990) by linear interpolation between B $D$. hamatus and T (top occurrence of) $S$. heteromorphus. Data from Site 845 provide calibration for some middle Miocene events. Among them, T S. heteromorphus has an estimated age of ca. $13.58 \mathrm{Ma}$, obtained by linear extrapolation from the base of Chrons $5 \mathrm{AAn}$ and $5 \mathrm{ABn}$. This age estimate results slightly older than the age (reestimated) of 13.49 Ma obtained from DSDP Site 608 (Backman et al., 1990). More detailed discussion of Leg 138 Miocene nannofossil biomagnetostratigraphy and comparison with other low- and mid-latitude magnetobiochronologies is reported in Raffi et al. (this volume).

\section{CHRONOSTRATIGRAPHY}

The chronostratigraphic framework we adopt for this paper is that used by Rio et al. (1990a), which divides the Miocene and Pliocene into subseries-subsystems. This informal large-scale subdivision does not refer to European chronostratigraphic units of the Neogene. In fact, stage-age units designated in European sequences are often difficult to recognize outside the type regions. This is because they rarely have updated and detailed biostratigraphic and magnetostratigraphic age controls. On the other hand, reference to a correct chronostratigraphic framework is important, because the chronostratigraphy (precise definition of chronostratigraphic boundaries) is "a common language" for international communication and correlation. The procedures followed in defining the subseries-subsystems reported in Figure 2 are somewhat different from those adopted in the Initial Reports volume ("Explanatory Notes" chapter in Mayer, Pisias, Janecek, et al., 1992), for they take into account recent revisions and difficulties encountered in Neogene chronostratigraphy (Rio et al., 1990a, 1990c). The adopted definitions of the chronostratigraphic boundaries and units are briefly explained below.

\section{The Pleistocene}

The Pleistocene is divided into middle-late and early Pleistocene, following the chronostratigraphy of Berggren et al. (1985) and Rio et al. (1991).

The middle-late/early Pleistocene boundary (top of Selinuntian stage, as proposed by Rio et al., 1991) approximates the time of intensification of Pleistocene glaciations and the establishment of a strong 100,000-yr. eccentricity cycle in the ice-volume record. With reference to calcareous nannofossil biostratigraphy, this boundary approximates (slightly postdates) the reentrance in the stratigraphic record of medium-sized Gephyrocapsa spp. (Rio et al., 1990b, 1991) between the base of Chron in (Brunhes) and the top of Subchron Ir. In (Jaramillo).

The definition of the Pleistocene/Pliocene boundary is based on the stratigraphic principle of establishing a boundary stratotype. The Vrica section (Calabria, Southern Italy) has been defined and accepted as the stratotype for the boundary (Aguirre and Pasini, 1985). Within this section, the top of the laminated level " $\mathrm{e}$ " in the Vrica section was selected as the marker horizon for the Pleistocene/Pliocene boundary (Aguirre and Pasini, 1985), and this level is just above the top of Chron 2n (Olduvai) (Tauxe et al., 1983; Hilgen, 1991a) at an age of ca. $1.81 \mathrm{Ma}$ (revised to the astronomically calibrated chronology of Hilgen, 1991a).

In the present work, we have recognized the boundary by the FO of medium Gephyrocapsa spp., which occurs in the equatorial Pacific just above the top of the Olduvai Subchron, as it does at the boundary stratotype section in the Mediterranean (Rio et al., in press).

\section{The Pliocene}

We divide the Pliocene series into two intervals (early and late Pliocene), following the generally used procedure for which the boundary is approximated by means of calcareous nannofossils, 
namely, the highest occurrence of Reticulofenestra pseudoumbilicus within Chron $2 \mathrm{Ar}$ (close to the upper part of the Gilbert). It should be noted that Rio et al. $(1991,1994)$ have recently proposed a tripartite subdivision into lower (Zanclean stage), middle (Piacenzian stage), and upper (Gelasian stage) Pliocene, as the time interval between the top of the Piacenzian stage (ca. 2.6 Ma) and the Pliocene/Pleistocene boundary (ca. 1.81 Ma) is not represented by a formally designated chronostratigraphic unit (and stratotype section).

\section{The Pliocene/Miocene Boundary}

The recognition of the Pliocene/Miocene boundary was considered controversial, owing to the difficulty in correlating this boundary (defined in the Mediterranean) to the open-ocean record. Sometimes different procedures (magnetostratigraphy, planktonic foraminifers or calcareous nannofossils) are used for placing the boundary in the same sequence, and this can lead to controversial identification of it (see discussion in Rio et al., 1990a). New results from land sections in Calabria (Zijderveld et al., 1986; Channell et al., 1988; Hilgen and Langereis, 1988) suggest that the boundary occurs slightly below the Thvera Subchron ( $3 n .4 n$ ) (in the upper part of Chron $3 r$ ), at an estimated age of about $5.32 \mathrm{Ma}$ (Hilgen, 1991b). In this paper, we placed the Pliocene/Miocene boundary within nannofossil Subzone $\mathrm{CN10a}$, between the appearance of Ceratolithus acutus (top) and the extinction of Discoaster quinqueramus (base), following Bukry (1973) who tentatively suggested the top of Subzone CN10a as the best approximation of this boundary, on the basis of correlations with Mediterranean stratotypes.

\section{The Late/Middle Miocene Boundary}

Berggren et al. (1985) defined the late/middle Miocene boundary (Tortonian/Serravallian boundary) at the base of the Tortonian stage and placed it within Zone CN6 (NN8), corresponding to the FO of Neogloboquadrina acostaensis. We have drawn the boundary in the upper part of nannofossil Zone CN7 (NN9), in agreement with the procedure followed by Rio et al. (1990a). Taking into account recent work in Italian sections (Rio et al., 1990c, and unpubl. data), Rio and co-workers saw that the bio- and magnetostratigraphic position of this boundary is unclear, owing to the poor quality of the data collected at the Mediterranean stratotype section of the Tortonian. Contradictions arise in the comparison and correlation of data from oceanic areas with the Mediterranean stratotype (see discussion in Rio et al., 1990a, for further details).

\section{The Early/Middle Miocene Boundary}

We followed the general criterion adopted by calcareous nannofossil paleontologists for recognizing the middle/early Miocene boundary and have drawn it at the top of Zone CN3 (NN4), just below the highest occurrence of Helicosphaera ampliaperta. With regard to chronostratigraphic units, the middle/early Miocene boundary is equivalent to the base of the Langhian stage (Berggren et al., 1985). This boundary is approximated by the FO of Preorbulina glomerosa curva (Cita and Premoli Silva, 1968), which is recorded above the FO of Sphenolithus heteromorphus in the stratotype section, just below the LO of $H$. ampliaperta, within the upper part of Zone NN4 (Martini, 1971).

\section{SITE SUMMARIES}

The preliminary biostratigraphic results included in the site chapters of the Initial Reports volume (Mayer, Pisias, Janecek, et al., 1992) show that the shipboard nannofossil biostratigraphy was sufficiently detailed to detect all major events. A general discussion of calcareous nannofossil biostratigraphy of the eastern equatorial Pacific, and a summary of the results at each site, are in the biostratigraphy chapter of this paper. We examined the middle and upper Miocene intervals by means of a new suite of more closely spaced samples. In this chapter, we report refinements to the on-board nannofossil biostratigraphy and discuss biostratigraphic details and problems that arose during our research. Biostratigraphic data were collected from composite depth sections constructed for each site (Hagelberg et al., 1992). These data are reported in Tables 3-12 and are illustrated in Figures 3-12. Depths of the data are reported in shipboard meters composite depth (mcd).

In the figures, we refer to the biostratigraphic scheme of Okada and Bukry (1980), which provides more resolution in some stratigraphic intervals. Details on the distribution patterns of stratigraphically indicative calcareous nannofossils in the middle and upper Miocene sections of some Leg 138 sites are reported in Raffi et al. (this volume). They collected quantitative data from many of the samples used in this study. We have excluded Site 854 from this report and refer the reader to the Initial Reports volume for Leg 138 for the nannofossil biostratigraphy of this sequence.

\section{Eastern Transect:} Sites $844,845,846$, and 847

The eastern transect sites were drilled in the vicinity of $95^{\circ} \mathrm{W}$ (Fig. 1 ), in the area where the equatorial current system interacts with the Peru Current. The primary objective at these sites was the reconstruction of the paleoceanography in this area, namely, the history of the current system and of oceanic productivity under the influence of coastal upwelling. Additional objectives included (1) calibrating lowlatitude biostratigraphies to the paleomagnetic time scale, by means of the anticipated magnetic stratigraphies at each site; (2) assisting in the reconstruction of the local tectonic history by providing biostratigraphic ages for previously undated magnetic anomalies in this region; and (3) determining the backtracked history of these sites.

\section{Site 844}

Site 844 is located in the Guatemala Basin, in an oceanographic region known as the Costa Rica Dome, a surface upwelling area with associated high open-ocean productivity. The site lies on the Cocos Plate, on basement formed at the East Pacific Rise approximately 17.5 m.y. ago (Mayer, Pisias, Janecek, et al., 1992).

The complete sediment sequence above the basalt basement was retrieved at Site 844 , and two lithologic units were recognized. In the Pleistocene-upper Miocene interval, the recovered sediments are clay-rich and biogenic silica-rich oozes with minimal carbonate (Unit I). In the middle to lower Miocene interval, the sediment is microfossil (mainly nannofossil) ooze (Unit II). A good magnetostratigraphy was obtained in the late Neogene interval (Schneider, this volume).

The average sampling interval for nannofossil analysis was $60 \mathrm{~cm}$ in Holes $844 \mathrm{~B}$ and $844 \mathrm{D}$ and in some cores from Hole $844 \mathrm{C}$. The nannofossil events we recognized are listed in Table 3. In the upper part of the sequence $(0-76 \mathrm{mcd})$, where siliceous microfossils (mainly diatoms) dominate, the relative abundance and preservation of calcareous nannofossils varies. Pleistocene nannofossil assemblages are diluted by siliceous microfossils and clay, but the major biostratigraphic events were recorded, despite the scarcity of nannofossils and the presence of barren intervals. A synthesis of the biostratigraphy at this site is presented in Figure 3.

Stratigraphic sections devoid of nannofossils are present within the Pliocene and upper Miocene intervals, and these sections are often characterized by reduced sedimentation rates. Consequently, in the lower Pliocene, we could not recognize Subzones CN12a, CN11b, CN11a, CN10c, and CN10b.

In the upper Miocene, we frequently encountered intervals containing few and strongly etched nannofossils. Barren intervals were observed within the CN7 (NN9) Zone. Nevertheless, the primary biostratigraphic events have been recognized by means of detailed analysis on short-spaced samples (about one sample every 0.048 m.y.). Nannofossils are abundant and well preserved in the middle and upper lower Miocene interval, except for discoasterids, which show strong overgrowths. The abundance of discoasterids varies throughout the 
Miocene and is significantly low in some intervals (i.e., within CN7, CN6, and CN5). This discoasterid distribution pattern observed at Site 844 , and at other Leg 138 sites, is typical beneath areas of strong upwelling and low abundances, and may be linked to enhanced upwelling conditions (Chepstow-Lusty et al., 1989, 1992). Within the middle Miocene Zone CN5 (NN7 and NN6), the following events were observed (Fig. 3): T (top occurrence of) common and continuous D. kugleri; B (bottom occurrence of) common and continuous $D$. kugleri; T C. nitescens; T C. premacintyrei; B T. rugosus; T D. signus; and $\mathrm{T} C$. floridanus. These events provide additional biostratigraphic information that may be useful for increasing the stratigraphic resolution within the zonal subdivision of this time interval.

The lowermost part of Site 844 is placed within Zone CN3 (NN4), and is characterized by intervals of $S$. heteromorphus blooms.

\section{Site 845}

Three holes were drilled in the Guatemala Basin at Site 845, the northernmost site of the eastern transect. A continuous late Neogene record was constructed from these holes and a high-resolution magnetostratigraphy was obtained from the Pliocene to the middle Miocene (Schneider, this volume). This high-quality polarity record allows us to calibrate the biostratigraphies and to obtain new biomagnetostratigraphic data for the refinement of Miocene bioevents in a low-latitude environment (see also Raffi et al., this volume).

In the Pleistocene-upper Miocene interval, the sediments are diatom and radiolarian clays (lithologic Unit I) with isolated occurrences of pelagic carbonate. Below, in the middle-lower Miocene interval, the lithology is mostly nannofossil ooze (Unit II) with metalliferous sediments at the bottom, just above the basalt basement. Nannofossil data indicate a basement age of 17 m.y., which is older than the age estimated from plate reconstructions (see Mayer, Pisias, Janecek, et al., 1992).

We sampled Hole $845 \mathrm{~A}$ and five cores of Hole $845 \mathrm{~B}$ at an average interval of $70 \mathrm{~cm}$. Detailed quantitative analyses were performed on closely spaced samples (about one sample every 0.025 m.y.) in the lowermost Pliocene-middle Miocene interval. The nannofossil events are summarized in Table 4 and Figure 4.

In the Pleistocene and upper Pliocene, the conventional biostratigraphic events were recognized. Nannofossil abundances are generally low throughout the interval because of clays and biosiliceous components. Most of the Pliocene section is barren of nannofossils, as the basal part of the upper Miocene corresponding to Zones CN8 and CN7 (NN10 and NN9). In the rest of the upper Miocene section (CN9 NN11), nannofossil assemblages are poorly preserved and show strong dissolution at some levels. In this interval, we could not detect T $A$. amplificus. Because discoasterids are considered a solution-resistant form of nannofossil (Ramsay, 1972, 1977; Ramsay et al., 1973), we expected their abundance to increase in the dissolved assemblages encountered in the upper Miocene (i.e., the upper part of Core 138. $845 \mathrm{~A}-13 \mathrm{H}$, just above a barren interval; Fig. 4). On the contrary, we observed generally low abundances of discoasterids in this interval. In fact, abundances are low in some samples that contained strongly etched nannofossils. If this part of the Miocene was characterized by enhanced productivity, then our observation supports the contention (Chepstow-Lusty et al., 1989, 1992) that discoasterid abundances are reduced when productivity increases. Detailed quantitative analysis is needed to clarify this pattern and to understand the influence of environmental factors on nannofossils in the eastern equatorial Pacific (see Flores et al., this volume, for upper Pliocene interval).

In the middle and lower Miocene interval, the assemblages are rich with well-preserved nannofossils. Only discoasterids, whose abundance fluctuates even in this interval, are strongly overgrown in some samples. The excellent paleomagnetic record obtained at this site allowed us to calibrate directly the B of $C$. coalitus and the additional events within Zone CN5 (Zones NN7 and NN6) that are recorded in the same biostratigraphic interval at Site 844 (Figs. 3-4). Despite overgrowths that hamper the recognition of most of the discoasterids, we were able to identify the acme end of $D$. deflandrei in the lower Miocene section. By quantitative analysis, we were able to determine the appearance of $D$. signus in the upper part of $\mathrm{CN} 3$ (NN4). In the lowermost samples, we were able to find an acme in the abundance of $S$. heteromorphus (Plate 1, Fig. 7).

\section{Site 846}

Site 846 is located approximately $300 \mathrm{~km}$ south of the Galapagos Islands, where the South Equatorial Current interacts with the Peru Current. The four holes drilled at this site recovered a sedimentary sequence of more than $400 \mathrm{~m}$, deposited since $16.5 \mathrm{Ma}$. The upper $200 \mathrm{~m}$ of the composite sedimentary section constructed at Site 846 is based on APC coring and is considered stratigraphically continuous. In the lower portion of the hole, recovered by XCB coring, small gaps occur in the composite section. The entire sedimentary section can be divided into two lithologic units: one consisting of alternating carbonate ooze (mostly nannofossil) and siliceous ooze (diatom and radiolarian) from 0 to about $350 \mathrm{mcd}$ (Unit $\mathrm{I}$ ); the other consisting of nannofossil ooze from about 350 to $455.3 \mathrm{mcd}$ (Unit II).

We sampled Hole $846 \mathrm{~B}$ and two cores of Hole $846 \mathrm{D}$ at an average interval of $70 \mathrm{~cm}$. In these samples, we recognized almost all the conventional biostratigraphic events from the Pleistocene back to the upper part of the lower Miocene. These results are summarized in Table 5 and Figure 5. Range charts are reported in Tables 13 and 14. Reworking of upper Miocene nannofossils was observed in several intervals within the upper Pliocene. Nannofossils are generally abundant and well preserved throughout the section, with the exception of the lower part of the upper Miocene (CN8-CN7-CN6), where we observed poorly preserved assemblages. This interval corresponds to the dissolution event seen at other Leg 138 sites. This event was related to a major paleoceanographic event observed in the Pacific (Mayer et al., 1986; Mayer, Pisias, Janecek, et al., 1992). In the same interval, the abundances observed in discoasterid assemblage are remarkably low. These low abundances were also observed upward in the section, in intervals close to the first appearance of Amaurolithus spp. The occurrence of these discoasterid-depleted intervals appears linked to particularly high abundances of diatoms. The distribution of ceratolithids is also irregular, generally characterized as rare and scattered. After their entrance in the stratigraphic record, A. primus and $A$. delicatus are often missing from the samples. The scarcity of ceratolithids also effects the distribution of $A$. amplificus, which seems to have a shorter range at Site 846 than at Sites $844,851,852$, and 853.

Although core recovery was poor in the lowermost part of the sedimentary sequence, the nannofossils from the few available samples of Cores 138-846B-42X and $-43 \mathrm{X}$ allowed us to place these sediments in the upper part of Zone CN3. The assemblage in the dark reddish brown metalliferous sediments atop the basalt basement, is characterized by very high abundances of $S$. heteromorphus.

\section{Site 847}

This site, located $280 \mathrm{~km}$ west of the Galapagos Islands, is the equatorial divergence site of the eastern transect. The sedimentary sequence was deposited in a complex tectonic area, at the transition between crust formed at the Galapagos Spreading Center and the East Pacific Rise (Mayer, Pisias, Janecek, et al., 1992). The four holes drilled at Site 847 provide a continuous sequence spanning the last 7 m.y. that primarily consists of nannofossil ooze with abundant diatoms in some intervals. Estimated sedimentation rates are quite constant (around $30 \mathrm{~m} / \mathrm{m} . y$.), except in the early Pliocene time interval, when sedimentation rates increase (Mayer, Pisias, Janecek, et al., 1992). The average nannofossil sampling interval of $60 \mathrm{~cm}$ from Hole 847B provides a temporal resolution approximately 20 k.y.

In the Pleistocene and upper Pliocene, calcareous nannofossils are abundant and preservation is generally good. Most of the conventional biostratigraphic events were identified (Table 6 and Fig. 6; range chart reported in Table 15), although in some intervals nanno- 
Table 13. Distrubution of calcareous nannofossil taxa in the Pleistocene-Pliocene interval at Site 846.

\begin{tabular}{|c|c|c|c|c|c|c|c|c|c|c|c|c|c|}
\hline $\begin{array}{l}\text { Zone } \\
\text { (CN) }\end{array}$ & $\begin{array}{l}\text { Core, section. } \\
\text { interval }(\mathrm{cm})\end{array}$ & $\begin{array}{l}\text { Depth } \\
\text { (mbsf) }\end{array}$ & $\begin{array}{l}\text { Depth } \\
\text { (mcd) }\end{array}$ & Abundance & Preservation & Etching & Overgrowth & $\begin{array}{c}\text { Small } \\
\text { Gephyrocapsa }\end{array}$ & P. lacunosa & G. omega & G. oceanica & $\begin{array}{c}\text { Large } \\
\text { Gephyrocapsa }\end{array}$ & H. sellii \\
\hline \multirow[t]{4}{*}{$15+14 B$} & $2 \mathrm{H}-5.60$ & 13.6 & 14.2 & A & G & 1 & 0 & A & & & ef. & & \\
\hline & $2 \mathrm{H}-6,54$ & 15.04 & 15.64 & A & G & 1 & 0 & A & & & & & \\
\hline & $2 \mathrm{H}-6,120$ & 15.7 & 16.3 & A & G & i & 0 & A & $\mathrm{R}$ & & $\mathrm{F}$ & & \\
\hline & $2 \mathrm{H}-7.20$ & 16.2 & 16.8 & A & G & $i$ & 0 & A & & & $\mathrm{F}$ & & \\
\hline \multirow[t]{6}{*}{$14 a$} & $2 \mathrm{H}-\mathrm{CC} .5$ & 16.79 & 17.39 & A & G & i & 0 & C & $\mathrm{F}$ & & $\mathrm{F}$ & & \\
\hline & $3 \mathrm{H}-\mathrm{I} .42$ & 16.92 & 18.97 & $\hat{A}$ & $\mathrm{G}$ & 0 & 0 & C & $\mathrm{F}$ & & $\mathrm{F}$ & & \\
\hline & $4 \mathrm{H}-\mathrm{I}, 40$ & 26.4 & 29.55 & A & G & 0 & 0 & $\mathrm{C}$ & A & $\mathrm{F}$ & & & \\
\hline & $4 \mathrm{H}-5,42$ & 32.42 & 35.57 & A & G & 0 & 0 & A & A & $\mathrm{F}$ & $\mathrm{F}$ & & \\
\hline & $4 \mathrm{H}-5,120$ & 33.2 & 36.35 & $\mathrm{~A}$ & G & i & 0 & A & A & $R$ & $\mathrm{~F}$ & & \\
\hline & $4 \mathrm{H}-6.45$ & 33.95 & 37.1 & A & G & i & 0 & $\mathrm{~F}$ & A & R & $\mathrm{R}$ & & \\
\hline \multirow[t]{15}{*}{$\overline{1} 3 \mathrm{~b}$} & $4 \mathrm{H}-6,120$ & 34.7 & 37.85 & A & G & i & 0 & C & A & & & & \\
\hline & $4 \mathrm{H}-7.20$ & 35.2 & 38.35 & $\mathrm{~A}$ & G & 0 & 0 & $\mathrm{~F}$ & A & & & & \\
\hline & $4 \mathrm{H}-7,54$ & 35.54 & 38.69 & A & G & 1 & 0 & $\mathrm{~F}$ & A & & & & \\
\hline & $5 \mathrm{H}-\mathrm{I} .49$ & 35.99 & 41.19 & A & G & 0 & 0 & C & A & & ef. & & \\
\hline & $5 \mathrm{H}-3,40$ & 38.9 & 44.1 & A & G & i & 0 & & $\mathrm{~A}$ & & & $\mathrm{R}$ & \\
\hline & $5 \mathrm{H}-3,120$ & 39.7 & 44.9 & A & G & i & 0 & & A & & & cf. & \\
\hline & $5 \mathrm{H}-4,40$ & 40.4 & 45.6 & $\mathrm{~A}$ & G & i & 0 & & A & & & $\mathrm{F}$ & \\
\hline & $5 \mathrm{H}-6,42$ & 43.42 & 48.62 & A & G & i & 0 & C & A & & $\mathrm{F}$ & C & \\
\hline & $6 \mathrm{H}-1.39$ & 45.39 & 51.89 & A & G & 0 & 0 & C & A & & C & C & \\
\hline & $6 \mathrm{H}-3,39$ & 48.39 & 54.89 & A & G & 1 & 0 & C & A & & C & $\mathrm{F}$ & \\
\hline & $6 \mathrm{H}-3,120$ & 49.2 & 55.7 & A & G & 0 & 0 & $\mathrm{~F}$ & C & & C & $\mathrm{R}$ & \\
\hline & $6 \mathrm{H}-4.39$ & 49.89 & 56.39 & A & G & i & 0 & C & A & & C & & $\mathrm{F}$ \\
\hline & $6 \mathrm{H}-5,40$ & 52.4 & 58.9 & C & G & i & 0 & A & C & & C & & F \\
\hline & $6 \mathrm{H}-6,20$ & 52.7 & 59.2 & A & G & $i$ & 0 & C & A & & $\mathrm{F}$ & & $\mathrm{F}$ \\
\hline & $6 \mathrm{H}-6,40$ & 52.9 & 59.4 & $\mathrm{~A}$ & G & $i$ & 0 & $\mathrm{~F}$ & A & & $\mathrm{F}$ & & $\mathrm{F}$ \\
\hline $13 \mathrm{a}$ & $6 \mathrm{H}-\mathrm{CC}, 5$ & 53.74 & 60.24 & A & G & I & 0 & $\mathrm{~F}$ & C & & cf. & & $\mathrm{F}$ \\
\hline & $7 \mathrm{H}-5.40$ & 55.5 & 63.8 & A & G & 0 & 0 & & A & & & & $\mathrm{F}$ \\
\hline & $8 \mathrm{H}-2,120$ & 66.7 & 76.4 & A & $\mathrm{G}$ & $i$ & 0 & & C & & & & C \\
\hline & $8 \mathrm{H}-3,43$ & 67.43 & 77.13 & A & M & 2 & 0 & & A & & & & \\
\hline $12 d+c$ & $8 \mathrm{H}-3,120$ & 68.2 & 77.9 & A & G & $i$ & 0 & & A & & & & C \\
\hline & $8 \mathrm{H}-3,140$ & 68.4 & 78.1 & C & $M$ & 2 & 0 & & $\mathrm{~A}$ & & & & $\mathrm{~F}$ \\
\hline & $8 \mathrm{H}-4,69$ & 69.19 & 78.89 & A & G & $i$ & 0 & & A & & & & $\mathrm{R}$ \\
\hline & $9 \mathrm{H}-4,60$ & 78.6 & 88.75 & A & G & $i$ & 0 & & C & & & & \\
\hline & $10 \mathrm{H}-\mathrm{I}, 60$ & 83.6 & 96.15 & A & G & 0 & 0 & & A & & & & \\
\hline $12 \mathrm{~b}$ & $10 \mathrm{H}-\mathrm{I}, 135$ & 84.35 & 96.9 & A & G & I & 0 & & A & & & & \\
\hline & $10 \mathrm{H}-2,60$ & 85.1 & 97.65 & $\mathrm{~A}$ & G & 0 & 1 & & A & & & & \\
\hline & $10 \mathrm{H}-3,60$ & 86.6 & 99.15 & $\mathrm{~A}$ & G & 0 & 0 & & C & & & & \\
\hline & $10 \mathrm{H}-5,60$ & 89.6 & 102.15 & A & G & 1 & 0 & & C & & & & \\
\hline & $11 \mathrm{H}-5,60$ & 99.1 & 112.6 & A & $\mathrm{G}$ & 0 & 0 & & C & & & & \\
\hline & $12 \mathrm{H}-2,120$ & 103.2 & 118 & $\mathrm{~A}$ & $M$ & $i$ & 1 & & C & & & & \\
\hline $12 \mathrm{ab}$ & $12 \mathrm{H}-3,60$ & 105.6 & 120.4 & A & M & i & $i$ & & $\mathrm{C}$ & & & & $\mathrm{F}$ \\
\hline & $12 \mathrm{H}-5,60$ & 108.6 & 123.4 & A & G & 0 & 0 & & C & & & & \\
\hline & $13 \mathrm{H}-1,60$ & 112.1 & 128.55 & A & G & 0 & 0 & & A & & & & $\mathrm{R}$ \\
\hline & $13 \mathrm{H}-7.40$ & 120.9 & 137.35 & $\mathrm{~A}$ & G & 0 & 1 & & C & & & & cf. \\
\hline & $14 \mathrm{H}-3,60$ & 124.6 & 141.75 & A & M & 1 & 2 & & $\mathrm{C}$ & & & & $\mathrm{F}$ \\
\hline & $14 \mathrm{H}-3,120$ & 125.2 & 142.35 & A & G & 1 & 0 & & A & & & & \\
\hline & $14 \mathrm{H}-4.60$ & 126.1 & 143.25 & A & G & 0 & 0 & & A & & & & $\mathrm{R}$ \\
\hline & $14 \mathrm{H}-4,120$ & 126.7 & 143.85 & A & $M$ & 1 & 0 & & C & & & & $\mathrm{F}$ \\
\hline $12 \mathrm{aA}$ & $14 \mathrm{H}-5,60$ & 127.6 & 144.75 & A & M & 0 & 0 & & C & & & & \\
\hline & 14H-CC. 3 & 130.56 & 147.71 & A & G & i & 0 & & C & & & & \\
\hline II & $15 \mathrm{H}-1,60$ & 131.1 & 150.8 & A & G & i & 0 & & & & & & \\
\hline & $15 H-3.60$ & 134.1 & 153.8 & $\mathrm{~A}$ & G & $i$ & 0 & & & & & & \\
\hline & $15 \mathrm{H}-7.40$ & 139.9 & 159.6 & A & G & 1 & 0 & & & & & & \\
\hline & $15 \mathrm{H}-7.63$ & 140.13 & 158.83 & A & M & i & 1 & & & & & & \\
\hline & $15 \mathrm{H}-\mathrm{CC}, 13$ & 140.45 & 160.15 & A & G & 1 & 0 & & & & & & \\
\hline & $16 \mathrm{H}-1.60$ & 140.6 & 160.8 & A & G & 1 & 0 & & & & & & \\
\hline & $16 \mathrm{H}-4.60$ & 145.1 & 165.3 & A & G & $i$ & 0 & & & & & & \\
\hline & $17 \mathrm{H}-1.50$ & 150 & 171.25 & A & G & i & 0 & & & & & & \\
\hline & $17 \mathrm{H}-1,120$ & 150.7 & 171.95 & A & M & 1 & 1 & & & & & & \\
\hline $10 \mathrm{c}$ & $17 \mathrm{H}-2.50$ & 151.5 & 172.75 & A & M & $i$ & 2 & & & & & & \\
\hline & $17 \mathrm{H}-2,120$ & 152.2 & 173.45 & A & M & 1 & 0 & & & & & & \\
\hline & $17 \mathrm{H}-5.50$ & 156 & 177.25 & A & $\mathrm{M}$ & i & 0 & & & & & & \\
\hline & $18 \mathrm{H}-1.50$ & 159.5 & 181.35 & A & M & 1 & 2 & & & & & & \\
\hline & $18 \mathrm{H}-3.50$ & 162.5 & 184.35 & A & M & 1 & 0 & & & & & & \\
\hline & $18 \mathrm{H}-6.50$ & 167 & 188.85 & A & M & 0 & 0 & & & & & & \\
\hline & $18 \mathrm{H}-7.13$ & 168.13 & 189.98 & A & M & 1 & 0 & & & & & & \\
\hline & $18 \mathrm{H}-\mathrm{CC}, 13$ & 168.97 & 190.82 & A & M & 1 & 0 & & & & & & \\
\hline & $19 \mathrm{H}-1.40$ & 168.9 & 192.7 & A & G & 0 & 0 & & & & & & \\
\hline & $19 \mathrm{H}-\mathrm{I} .120$ & 169.7 & 193.5 & A & M & 1 & 0 & & & & & & \\
\hline & $19 \mathrm{H}-3,40$ & 171.9 & 195.7 & A & G & 0 & 0 & & & & & & \\
\hline & $19 \mathrm{H}-3.120$ & 172.7 & 196.5 & A & G & 0 & 0 & & & & & & \\
\hline $10 \mathrm{~b}$ & $19 \mathrm{H}-4,40$ & 173.4 & 197.2 & A & M & 1 & 0 & & & & & & \\
\hline & $20 \mathrm{H}-3.50$ & 181.5 & 207.1 & A & G & 0 & 0 & & & & & & \\
\hline & $20 \mathrm{H}-3,120$ & 182.2 & 207.8 & A & M & 1 & 2 & & & & & & \\
\hline $10 \mathrm{a}$ & $20 \mathrm{H}-4,50$ & 183 & 208.6 & A & M & 1 & 2 & & & & & & \\
\hline & $20 \mathrm{H}-5.50$ & 184.5 & 210.1 & A & M & 1 & 1 & & & & & & \\
\hline & $21 \mathrm{H}-3,50$ & 191 & 217.95 & A & $\mathrm{M}$ & i & 2 & & & & & & \\
\hline & $21 \mathrm{H}-4,50$ & 192.5 & 219.45 & A & G & i & 0 & & & & & & \\
\hline
\end{tabular}

Notes: For an explanation of the abundance and preservation codes, see text. For genus names, see Appendix A. 
R 
Table 13 (continued).

\begin{tabular}{|c|c|c|c|c|c|c|c|c|c|c|c|}
\hline $\begin{array}{l}\text { Zone } \\
(\mathrm{CN})\end{array}$ & $\begin{array}{l}\text { Core, section, } \\
\text { interval }(\mathrm{cm})\end{array}$ & A. primus & A. tricomiculatus & C. acutus & C. armatus & C. Ieptoporis & C. cristatus & C. telesmus & $C$, pelugicus & D. imtercalaris & D. variahilis \\
\hline \multirow[t]{4}{*}{$15+14 b$} & $2 \mathrm{H}-5,60$ & & & & C & & & & & & \\
\hline & $2 \mathrm{H}-6,54$ & & & & & C & & & & & \\
\hline & $2 \mathrm{H}-6,120$ & & & & & C & & & & & \\
\hline & $2 \mathrm{H}-7,20$ & & & & & C & & & & & \\
\hline \multirow[t]{6}{*}{$14 a$} & $2 \mathrm{H}-\mathrm{CC} .5$ & & & & & c & & & & & \\
\hline & $3 \mathrm{H}-\mathrm{I}, 42$ & & & & & C & $\mathrm{F}$ & $\mathrm{F}$ & & & \\
\hline & $4 \mathrm{H}-1.40$ & & & & & C & & & & & \\
\hline & $4 \mathrm{H}-5.42$ & & & & & C & & & & & \\
\hline & $4 \mathrm{H}-5,120$ & & & & & C & C & & & & \\
\hline & $-4 \mathrm{H}-6.45$ & & & & & C & & & & & \\
\hline \multirow[t]{15}{*}{$13 \mathrm{~b}$} & $4 \mathrm{H}-6.120$ & & & & & C & & & & & \\
\hline & $4 \mathrm{H}-7.20$ & & & & & C & & & & & \\
\hline & $4 \mathrm{H}-7.54$ & & & & & C & R & & & & \\
\hline & $5 \mathrm{H}-1,49$ & & & & & $\mathrm{~F}$ & & & & & \\
\hline & $5 \mathrm{H}-3.40$ & & & & & C & & & & & \\
\hline & $5 \mathrm{H}-3,120$ & & & & & c & $\mathrm{F}$ & $R$ & & & \\
\hline & $5 \mathrm{H}-4.40$ & & & & & C & R & R & & & \\
\hline & $5 \mathrm{H}-6,42$ & & & & & C & & & & & \\
\hline & $6 \mathrm{H}-1,39$ & & & & & C & $\mathrm{F}$ & & & & \\
\hline & $6 \mathrm{H}-3.39$ & & & & & C & R & & & & \\
\hline & $6 \mathrm{H}-3,120$ & & & & & c & $\hat{\mathrm{F}}$ & & $\mathrm{R}$ & & \\
\hline & $6 \mathrm{H}-4,39$ & & & & & C & $\mathrm{R}$ & & $\mathrm{F}$ & & \\
\hline & $6 \mathrm{H}-5.40$ & & & & & C & & & C & & \\
\hline & $6 \mathrm{H}-6,20$ & & & & & C & & & $\mathrm{R}$ & & \\
\hline & $6 \mathrm{H}-6.40$ & & & & & C & & & C & & \\
\hline \multirow{4}{*}{$1 \bar{a}$} & $6 \mathrm{H}-\mathrm{CC} .5$ & & & & & C & F & & $\mathrm{F}$ & & \\
\hline & $7 \mathrm{H}-5,40$ & & & & & $\mathrm{~F}$ & $\mathrm{R}$ & & C & & \\
\hline & $8 \mathrm{H}-2,120$ & & & & & C & & & C & & \\
\hline & $8 \mathrm{H}-3,43$ & & & & & C & & & $\mathrm{F}$ & & \\
\hline $12 d+c$ & $8 \mathrm{H}-3,120$ & & & & & $\mathrm{C}$ & & & C & & \\
\hline & $8 \mathrm{H}-3.140$ & & & & & C & & & C & & \\
\hline & $8 \mathrm{H}-4,69$ & & & & & C & R & & C & & \\
\hline & $9 \mathrm{H}-4,60$ & & & & & C & $\mathrm{F}$ & & C & & \\
\hline & $10 \mathrm{H}-\mathrm{I} .60$ & & & & & c & R & & C & & \\
\hline $12 \mathrm{~b}$ & $10 \mathrm{H}-1.135$ & & & & & C & & & C & & \\
\hline & $10 \mathrm{H}-2.60$ & & & & cf. & C & & & c & & \\
\hline & $10 \mathrm{H}-3,60$ & & & & & c & & & C & & \\
\hline & $10 \mathrm{H}-5,60$ & & & & & C & R & $\mathrm{F}$ & C & $\mathrm{R}$ & \\
\hline & $1 \mathrm{IH}-5.60$ & & & & & C & & & C & & \\
\hline & $12 \mathrm{H}-2,120$ & & & & & C & $\mathrm{R}$ & & $\mathrm{F}$ & & \\
\hline $12 \mathrm{aB}$ & $12 \mathrm{H}-3,60$ & & & & & C & & & C & & \\
\hline 政 & $12 \mathrm{H}-5,60$ & & & & & C & $\mathrm{F}$ & & C & $\mathrm{F}$ & \\
\hline & $13 \mathrm{H}-1.60$ & & & & cf. & C & F & & C & F & \\
\hline & $13 \mathrm{H}-7.40$ & & & & & C & $\mathrm{F}$ & & $\mathrm{F}$ & & \\
\hline & $14 \mathrm{H}-3,60$ & & & & cf. & C & $\mathrm{F}$ & cf. & C & & cf. \\
\hline & $14 \mathrm{H}-3.120$ & & & & & C & & & $\mathrm{F}$ & R & \\
\hline & $14 \mathrm{H}-4.60$ & & & & ef. & C & F & & C & & $\mathrm{R}$ \\
\hline & $14 \mathrm{H}-4,120$ & & & & & C & $\mathrm{R}$ & cf. & $\mathrm{F}$ & $\mathrm{R}$ & \\
\hline $12 \mathrm{aA}$ & $14 \mathrm{H}-5,60$ & & & & $\mathrm{~F}$ & c & $\mathrm{F}$ & $\mathrm{F}$ & $\mathrm{F}$ & $\mathrm{F}$ & $\mathrm{F}$ \\
\hline & I4H-CC. 3 & & & & $\mathrm{~F}$ & C & $\mathrm{F}$ & & $\mathrm{F}$ & $\mathrm{F}$ & \\
\hline II & $15 \mathrm{H}-1.60$ & & & & F & C & & & F & & F \\
\hline & $15 \mathrm{H}-3,60$ & & & & $\mathrm{~F}$ & C & $\mathrm{F}$ & & $\mathrm{F}$ & F & $\mathrm{R}$ \\
\hline & $15 \mathrm{H}-7,40$ & & & & F & c & $\mathrm{F}$ & $\mathrm{R}$ & F & $\mathrm{F}$ & \\
\hline & $15 \mathrm{H}-7.63$ & $\mathrm{R}$ & $\mathrm{R}$ & & F & C & F & & C & & \\
\hline & $15 \mathrm{H}-\mathrm{CC}, 13$ & & & & & C & & & C & F & $\mathrm{F}$ \\
\hline & $16 \mathrm{H}-1.60$ & & & & $\mathrm{~F}$ & C & F & & $\mathrm{F}$ & F & \\
\hline & $16 \mathrm{H}-4.60$ & & & & $\mathrm{~F}$ & C & & & C & $\mathrm{F}$ & $\mathrm{F}$ \\
\hline & $17 \mathrm{H}-1.50$ & & & & $\mathrm{R}$ & C & R & & C & $\mathrm{F}$ & $\mathrm{F}$ \\
\hline & $17 \mathrm{H}-1.120$ & & & & & c & & & C & F & \\
\hline $10 \mathrm{c}$ & $17 \mathrm{H}-2.50$ & $\mathrm{R}$ & & & & C & & & C & $\mathrm{F}$ & R \\
\hline & $17 \mathrm{H}-2,120$ & & & & & C & & $\mathrm{R}$ & C & & C \\
\hline & $17 \mathrm{H}-5,50$ & $\mathrm{R}$ & & & $R$ & C & & & & $\mathrm{R}$ & $\mathrm{R}$ \\
\hline & $18 \mathrm{H}-1.50$ & R & & & & C & & & & & $\mathrm{F}$ \\
\hline & $18 \mathrm{H}-3.50$ & $\ddot{R}$ & & & & C & & & C & & $\mathrm{F}$ \\
\hline & $18 \mathrm{H}-6.50$ & R & $\mathrm{R}$ & & R & c & & & $\mathrm{F}$ & & C \\
\hline & $18 \mathrm{H}-7.13$ & & & & C & cf. & & $\mathrm{F}$ & R & & $\mathrm{F}$ \\
\hline & $18 \mathrm{H}-\mathrm{CC}, 13$ & & & & cf. & C & & & $\hat{F}$ & & \\
\hline & $19 \mathrm{H}-1.40$ & $\mathrm{R}$ & & & & C & & & C & C & \\
\hline & $19 \mathrm{H}-1.120$ & & & & cf. & C & & & $\mathrm{F}$ & & \\
\hline & $19 \mathrm{H}-3.40$ & & & $\mathrm{R}$ & & C & & & C & & \\
\hline & $19 \mathrm{H}-3,120$ & & & $\mathrm{~F}$ & & C & & & C & $\mathrm{F}$ & $\mathrm{R}$ \\
\hline $10 \mathrm{~b}$ & $19 \mathrm{H}-4.40$ & & & R & & C & & & $\mathrm{F}$ & $\mathrm{F}$ & $\mathrm{F}$ \\
\hline & $20 \mathrm{H}-3.50$ & & & $\hat{F}$ & & C & & & C & $\mathrm{F}$ & $\mathrm{F}$ \\
\hline & $20 \mathrm{H}-3,120$ & & & $\mathrm{~F}$ & cf. & C & & & C & F & $\mathrm{R}$ \\
\hline $10 \mathrm{a}$ & $20 \mathrm{H}-4,50$ & $\mathrm{R}$ & $\mathrm{R}$ & & & $\mathrm{C}$ & & & $\mathrm{F}$ & F & F \\
\hline & $20 \mathrm{H}-5,50$ & $\mathrm{R}$ & & & & C & & & $\mathrm{F}$ & F & $\mathrm{F}$ \\
\hline & $21 \mathrm{H}-3,50$ & $\mathrm{R}$ & $\mathrm{R}$ & & & C & & & C & F & F \\
\hline & $2 \mathrm{H}-4,50$ & R & & & & $\mathrm{C}$ & & & C & $\mathrm{F}$ & $\mathrm{F}$ \\
\hline
\end{tabular}

fossil assemblages are difficult to interpret because of dilution by biosiliceous material. Among Pliocene discoasterids, D. pentaradiatus is very rare in the upper Pliocene, thus preventing the identification of Subzone CN12b (Zone NN17).

In the lower Pliocene and upper Miocene intervals (below 145 mcd; range chart in Table 16) preservation deteriorates, overgrowths affect discoasterids, and sometimes it was not possible to differentiate the species. Variations in the relative abundance of discoasterids, ceratolithids, and triquetrorhabdulids were observed, mostly in the upper Miocene interval.

The lower part of the Site 847 section was placed in Subzone $\mathrm{CN} 9 \mathrm{~b}$, because of the presence of representatives of genus Amaurolithus, together with generally rare and overgrown $D$. berggrenii and D. quinqueramus.

In the lowermost part of the sequence, we observed strong reworking of lower Miocene nannofossils. These older forms (Sphenolithus 
Table 13 (continued).

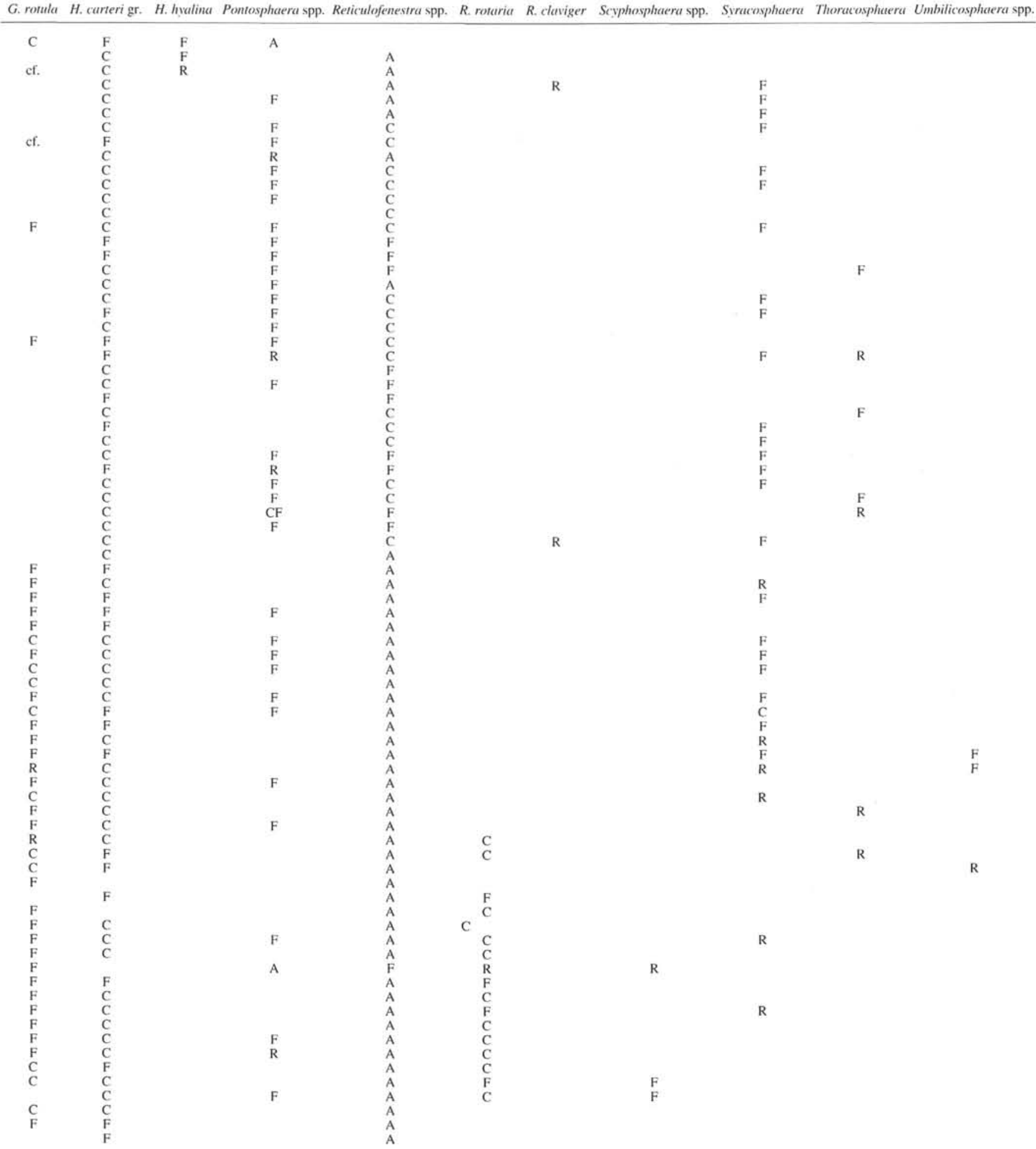

conicus, S. dissimilis, S. belemnos-dissimilis, and Helicosphaera intermedia) are particularly abundant in the calcareous veneer scraped from the cherts that are the deepest samples retrieved at Site 847. The finding of lower Miocene reworked material in the sediments at Site 847 is particularly intriguing as it raises new questions regarding the complex tectonic history of an area with crust thought to be about 9 m.y. old (Hey, 1977).

\section{Western Transect: Sites $848,849,850,851,852$, and 853}

The western transect sites were drilled at $110^{\circ} \mathrm{W}$ (Fig. 1), in an area where the equatorial current system is removed from the direct influence of the eastern boundary currents. Studies of the sedimentary sequences retrieved along this transect are designed to reconstruct the 
Table 14. Distribution of calcareous nannofossil taxa in the Miocene interval at Site 846.

\begin{tabular}{|c|c|c|c|c|c|c|c|c|c|c|c|}
\hline $\begin{array}{l}\text { Zone } \\
\text { (CN) }\end{array}$ & $\begin{array}{l}\text { Core, section, } \\
\text { interval }(\mathrm{cm})\end{array}$ & $\begin{array}{l}\text { Depth } \\
\text { (mbsf) }\end{array}$ & $\begin{array}{l}\text { Depth } \\
\text { (med) }\end{array}$ & Abundance & Preservation & Etching & Overgrowth & D. brouweri & D. pentaradiatus & D. surculus & C. macintyrei \\
\hline $10 \mathrm{a}$ & $21 \mathrm{H}-4,50$ & 192.5 & 219.45 & A & M & 1 & 1 & $\mathrm{~F}$ & & $\mathrm{~F}$ & $\mathrm{R}$ \\
\hline & $21 \mathrm{H}-4,120$ & 193.2 & 220.15 & A & M & i & i & & & $\mathrm{F}$ & $\mathrm{R}$ \\
\hline & $2 \mathrm{H}-5,50$ & 194 & 220.95 & A & G & i & 0 & $\mathbf{R}$ & & $\mathrm{F}$ & \\
\hline $9 \mathrm{bc}$ & $21 \mathrm{H}-7,50$ & 197 & 223.95 & $\hat{A}$ & G & i & 0 & W & & F & R \\
\hline & $22 \mathrm{H}-3,50$ & 200.5 & 230.95 & A & M & 2 & i & $\mathrm{F}$ & & $\mathrm{F}$ & \\
\hline & $23 \mathrm{X}-1,50$ & 207.7 & 241 & A & $\mathrm{M}$ & 2 & $i$ & $\mathrm{~F}$ & & $\mathrm{~F}$ & \\
\hline & $23 \mathrm{X}-3,50$ & 210 & 244 & A & $\mathrm{M}$ & 2 & 2 & $\mathrm{~F}$ & & $\mathrm{~F}$ & \\
\hline & $23 \mathrm{X}-3,120$ & 210.7 & 244.7 & A & M & $i$ & 2 & R & & $\mathrm{R}$ & \\
\hline $9 \mathrm{bB}$ & $23 \times-4,50$ & 211.5 & 245.5 & A & $\mathrm{M}$ & 2 & 2 & $\hat{F}$ & $\mathbf{R}$ & $\hat{\mathrm{F}}$ & $\mathrm{R}$ \\
\hline & $23 \times-5,50$ & 213 & 247 & A & M & i & 2 & $\mathrm{~F}$ & & F & \\
\hline & $23 \mathrm{X}-\mathrm{CC}, 10$ & 216.15 & 250.15 & A & M & 2 & $i$ & C & & $\mathrm{R}$ & \\
\hline & $24 \mathrm{X}-1,40$ & 216.6 & 252 & $\hat{A}$ & $\mathrm{G}$ & $i$ & 0 & $\mathrm{~F}$ & & $\mathrm{~F}$ & \\
\hline & $24 \mathrm{X}-3,40$ & 219.6 & 255 & A & $M$ & 2 & i & R & & $\mathrm{R}$ & $\mathrm{F}$ \\
\hline & $24 \mathrm{X}-5,40$ & 22.6 & 258 & A & M & i & i & $\mathrm{C}$ & & $\mathrm{F}$ & \\
\hline & $24 X-7,25$ & 252.45 & 260.85 & $\hat{A}$ & $\mathrm{M}$ & i & i & $\mathrm{F}$ & & & \\
\hline & $25 \mathrm{X}-1,50$ & 226.2 & 261.3 & $\hat{A}$ & $\mathrm{G}$ & i & 0 & C & & & F \\
\hline & $25 \times-2,39$ & 227.59 & 262.69 & A & G & I & 0 & F & & $\mathrm{F}$ & \\
\hline & $25 X-3,40$ & 229.1 & 264.2 & A & M & i & 1 & c & & & \\
\hline 9bA & $25 X-5,16$ & 231.86 & 266.96 & A & G & i & 0 & $\mathrm{~F}$ & & $\mathrm{R}$ & $\mathrm{F}$ \\
\hline & 138-846D- & & & & & & & & & & \\
\hline & $\begin{array}{l}26 \mathrm{X}-1,120 \\
26 \mathrm{X}-2,120\end{array}$ & $\begin{array}{l}241 \\
242.5\end{array}$ & $\begin{array}{l}278.8 \\
276.3\end{array}$ & $\begin{array}{l}\text { A } \\
\text { A }\end{array}$ & $\begin{array}{l}\mathrm{G} \\
\mathrm{M}\end{array}$ & i & $\begin{array}{l}0 \\
2\end{array}$ & $\underset{F}{F}$ & & $\mathrm{~F}$ & \\
\hline & $26 \mathrm{X}-3,120$ & $\begin{array}{l}244.3 \\
\end{array}$ & 277.8 & $\begin{array}{l}\mathrm{A} \\
\mathrm{A}\end{array}$ & $\underset{G}{M}$ & 1 & 0 & $\mathrm{~F}$ & & & \\
\hline & $26 \mathrm{X}-5,120$ & 247 & 280 & A & $\mathrm{M}$ & 1 & i & $\mathrm{F}$ & & $\mathrm{R}$ & C \\
\hline & $26 \mathrm{X}-6,120$ & 248.5 & 282.3 & $\hat{A}$ & G & i & 0 & $\mathrm{R}$ & & $\mathrm{R}$ & $\mathrm{F}$ \\
\hline & $26 \times-7,23$ & 249.03 & 282.83 & A & G & i & 0 & C & & $\mathrm{F}$ & \\
\hline & $28 \mathrm{X}-3,60$ & 258.5 & 293.6 & $\hat{A}$ & $M$ & i & i & F & & & $\mathrm{F}$ \\
\hline & $29 \mathrm{X}-1,60$ & 264.8 & 299.9 & $\hat{A}$ & $\mathrm{M}$ & $i$ & $i$ & $\mathrm{~F}$ & & & \\
\hline 9a & $29 \times-2,60$ & 266.3 & 301.4 & A & $\mathrm{G}$ & $i$ & 0 & $\mathrm{~F}$ & & & \\
\hline & $29 \mathrm{X}-3,60$ & 267.8 & 302.9 & A & $\mathrm{G}$ & i & 0 & $\mathrm{~F}$ & & & \\
\hline & $29 \times-4,60$ & 269.3 & 304.4 & A & $\mathrm{G}$ & 1 & 0 & $\mathrm{~F}$ & & & \\
\hline & $29 \times-4,120$ & 269.9 & 305 & c & G & $\mathrm{i}$ & 0 & $\mathrm{R}$ & & & \\
\hline & $29 X-5,60$ & 270.8 & 305.9 & A & G & i & 0 & R & & & \\
\hline & $29 \mathrm{X}-5,120$ & 271.4 & 306.5 & A & M & i & i & $\mathrm{F}$ & & & $\mathrm{R}$ \\
\hline $8 b$ & $30 \times-1,60$ & 274.5 & 309.6 & A & M & i & 2 & $\mathrm{R}$ & & & \\
\hline 80 & $30 X-2,60$ & 276 & 311.1 & $\hat{A}$ & $\mathrm{M}$ & i & 2 & R & & & \\
\hline & $30 X-3,60$ & 277.5 & 312.6 & $\hat{A}$ & $\mathrm{M}$ & $i$ & 2 & $\hat{R}$ & & & \\
\hline & $30 X-4,60$ & 279 & 314.1 & A & $\mathrm{M}$ & i & 2 & $\mathrm{R}$ & & & \\
\hline & $30 \mathrm{X}-7,40$ & 283.3 & 318.4 & $\hat{A}$ & G & i & 0 & $\kappa$ & & & \\
\hline & $31 \times-4,60$ & 288.6 & 323.7 & A & M & I & 2 & F & & & \\
\hline & $31 \times-7,40$ & 292.9 & 328 & A & G & i & 0 & $\mathrm{R}$ & & & $\mathrm{F}$ \\
\hline $8 a$ & $32 \mathrm{X}-1,60$ & 293.7 & 328.8 & C & M & i & 1 & cf. & & & \\
\hline oda & $32 X-2,60$ & 295.2 & 330.3 & A & $\mathrm{M}$ & 2 & i & 1. & & cf. & \\
\hline & $32 X-3,60$ & 296.7 & 331.8 & A & $\mathrm{M}$ & 2 & i & F & & & $\mathrm{F}$ \\
\hline & $32 X-4,60$ & 298.2 & 333.3 & C & $\mathrm{M}$ & 2 & i & & & & $\mathrm{R}$ \\
\hline & $32 \times-5,60$ & 299.7 & 334.8 & C & $\mathrm{M}$ & 2 & 1 & $\mathrm{R}$ & & & \\
\hline & $32 X-5,120$ & 300.3 & 335.4 & A & $\mathrm{M}$ & 2 & 1 & $\kappa$ & & & C \\
\hline & $32 X-6,60$ & 301.2 & 336.3 & C & M & 2 & 1 & & & & \\
\hline & $32 X-6,120$ & 301.8 & 336.9 & A & M & $i$ & i & $\mathrm{F}$ & & cf. & \\
\hline 7 & $32 \times-7,10$ & 302.2 & 337.3 & C & M & 2 & i & & & & $\mathrm{R}$ \\
\hline & $33 \mathrm{X}-1,60$ & 303.4 & 338.5 & A & $\mathrm{M}$ & i & i & & & & \\
\hline & $33 \times-4,60$ & 307.9 & 343 & $\hat{\mathrm{C}}$ & $\mathrm{M}$ & 2 & i & & & & \\
\hline & $33 \mathrm{X}-4,120$ & 308.5 & 343.6 & C & $\mathrm{M}$ & 2 & 1 & & & & $\mathbf{R}$ \\
\hline & $33 \mathrm{X}-5,60$ & 309.4 & 344.5 & C & $\mathrm{M}$ & 2 & i & & & & \\
\hline 6 & $33 \times-5,120$ & 310 & 345.1 & c & $\mathrm{M}$ & 2 & i & & & & $\mathrm{F}$ \\
\hline & $33 \mathrm{X}-6,60$ & 310.9 & 346 & c & $\mathrm{M}$ & 2 & i & & & & $\mathrm{R}$ \\
\hline & $33 \mathrm{X}-6,120$ & 311.5 & 346.6 & C & $\mathrm{M}$ & 2 & i & & & & $\mathrm{R}$ \\
\hline & $33 \times-7,34$ & 312.14 & 347.24 & C & $\mathrm{M}$ & 2 & i & & & & $\mathrm{R}$ \\
\hline & $34 \mathrm{X}-2,60$ & & & C & G & i & $i$ & & & & $\mathrm{R}$ \\
\hline & $34 X-4,60$ & & & C & G & i & i & & & & $\mathrm{R}$ \\
\hline & $34 \mathrm{X}-7,60$ & & & A & G & i & i & & & & R \\
\hline & $35 \mathrm{X}-1,120$ & & & A & G & 0 & 0 & & & & \\
\hline & $35 \times-2,120$ & & & A & G & 0 & 0 & & & & \\
\hline & $35 \mathrm{X}-4,120$ & & & A & G & 0 & 1 & & & & \\
\hline & $35 \times-6,120$ & & & A & G & 0 & i & & & & \\
\hline $5 b$ & $36 \mathrm{X}-1,36$ & & & A & G & 0 & i & & & & \\
\hline & $36 \times-4,40$ & & & A & G & 0 & $i$ & & & & \\
\hline & $36 \times-6,68$ & & & $\hat{A}$ & $G$ & 0 & 1 & & & & \\
\hline & $37 \mathrm{X}-1.58$ & & & $\hat{A}$ & G & 0 & $i$ & & & & \\
\hline & $37 X-3,26$ & & & A & G & 0 & $i$ & & & & \\
\hline & $38 X-2,50$ & & & A & G & 0 & 1 & & & & \\
\hline & $38 \times-3,50$ & & & A & G & 0 & 1 & & & & \\
\hline & $38 \mathrm{X}-5,120$ & 358.2 & 393.3 & A & M & 2 & 1 & & & & \\
\hline & $38 \mathrm{X}-6,50$ & 359 & 394.1 & A & M & 2 & i & & & & R \\
\hline $5 a$ & $38 \mathrm{X}-6,120$ & 359.7 & 394.8 & A & M & i & 2 & & & & \\
\hline & $38 \mathrm{X}-\mathrm{CC}, 10$ & 360.01 & 395.11 & A & $\mathrm{M}$ & 2 & $i$ & & & & \\
\hline & $40 \mathrm{X}-1.40$ & 370.7 & 405.8 & A & M & 2 & i & & & & \\
\hline & $40 X-2,100$ & 372.8 & 407.9 & A & M & 2 & i & & & & \\
\hline 4 & $40 X-3.120$ & 374.5 & 409.6 & A & M & $i$ & $i$ & & & & \\
\hline & $40 \mathrm{X}-\mathrm{CC}, 10$ & 377.9 & 413 & $\hat{A}$ & $\mathrm{M}$ & $i$ & $i$ & & & & \\
\hline & $41 X-3,60$ & 383.5 & 418.6 & A & M & i & i & & & & \\
\hline & 4IX-CC. 9 & 386.77 & 421.87 & $\hat{A}$ & $\mathrm{M}$ & $\mathrm{i}$ & $\mathrm{i}$ & & & & \\
\hline & $42 \mathrm{X}-1,79$ & 390.39 & 425.47 & $\hat{A}$ & $\mathrm{M}$ & $i$ & i & & & & \\
\hline & $42 \mathrm{X}-1,113$ & 390.73 & 425.83 & $\hat{A}$ & $\mathrm{M}$ & i & i & & & & \\
\hline 3 & $42 \mathrm{X}-\mathrm{CC}, 12$ & 390.9 & 426 & $\hat{A}$ & $\mathrm{M}$ & i & $i$ & & & & \\
\hline & $43 \mathrm{X}-\mathrm{CC}, 3$ & 399.23 & 434.33 & A & $\mathrm{M}$ & $i$ & $i$ & & & & \\
\hline & $44 X-3.60$ & 412.5 & 447.6 & $\hat{A}$ & M & 2 & i & & & & \\
\hline
\end{tabular}


Table 14 (continued).

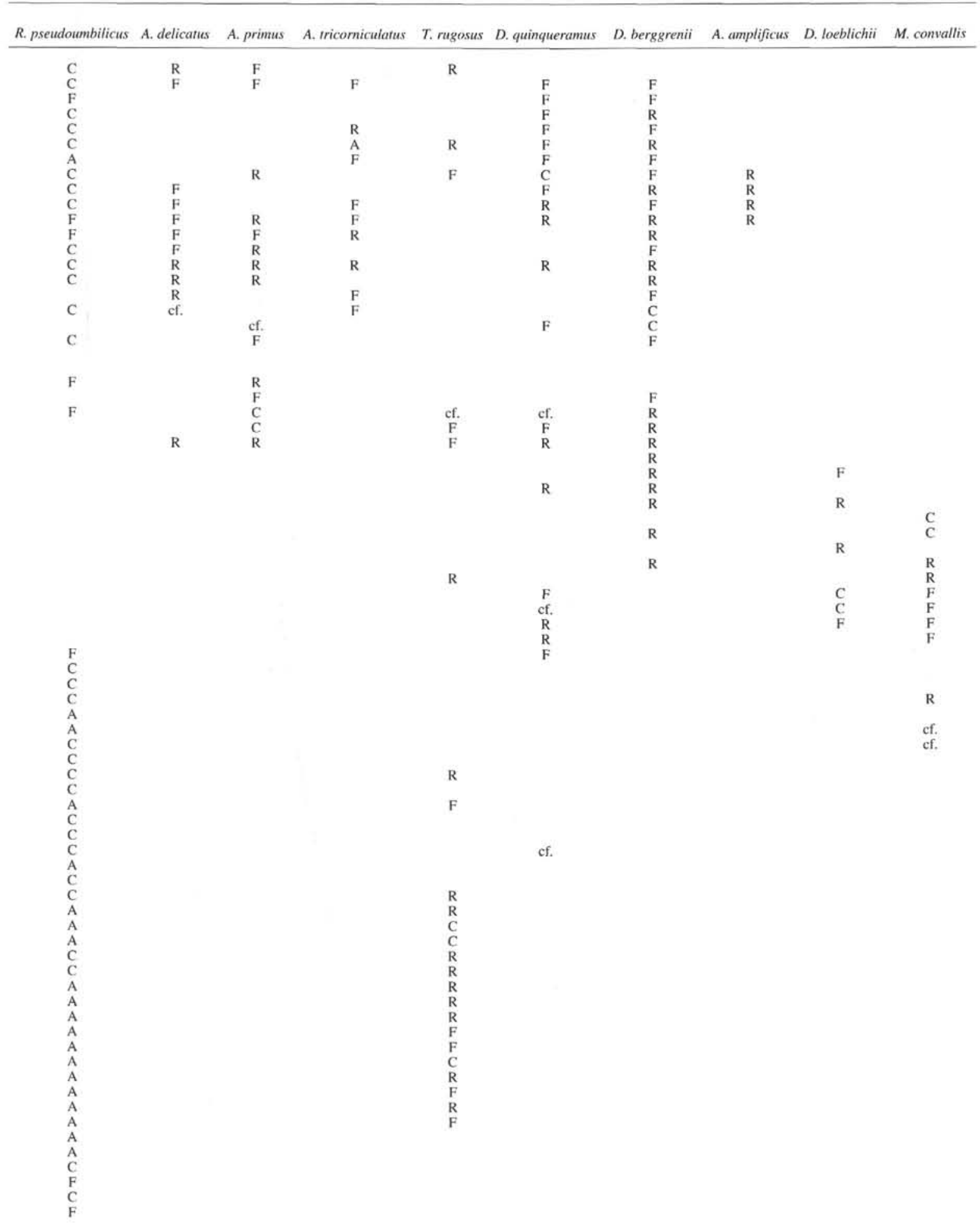

ef. 
I. RAFFI, J.-A. FLORES

Table 14 (continued).

\begin{tabular}{|c|c|c|c|c|c|c|c|c|c|c|c|}
\hline $\begin{array}{l}\text { Zone } \\
\text { (CN) }\end{array}$ & $\begin{array}{l}\text { Core, section, } \\
\text { interval }(\mathrm{cm})\end{array}$ & D. neohamatus & D. bollii & D. hamatus & C. miopelagicus & C. coalitus & D. kugleri & C. nitescens & C. floridamus & S. heteromorphus & H. ampliaperta \\
\hline \multirow[t]{2}{*}{$10 a$} & $21 \mathrm{H}-4,50$ & & & & & & & & & & \\
\hline & $\begin{array}{l}21 \mathrm{H}-4,120 \\
21 \mathrm{H}-5,50\end{array}$ & & & & & & & & & & \\
\hline \multirow[t]{3}{*}{$9 \mathrm{bc}$} & $21 \mathrm{H}-7,50$ & & & & & & & & & & \\
\hline & $22 \mathrm{H}-3,50$ & & $\mathrm{R}$ & & & & & & & & \\
\hline & $\begin{array}{l}23 X-1,50 \\
23 X-3,50\end{array}$ & & & & & & & & & & \\
\hline \multirow{8}{*}{$9 \mathrm{bB}$} & $\begin{array}{l}23 \mathrm{X}-3,120 \\
23 \mathrm{X}-4,50\end{array}$ & & $\mathrm{~F}$ & & & & & & & & \\
\hline & $23 \mathrm{X}-5.50$ & & c1. & & & & & & & & \\
\hline & $\begin{array}{l}23 \mathrm{X}-\mathrm{CC}, 10 \\
24 \mathrm{X}-1.40\end{array}$ & & $\begin{array}{l}\text { cf. } \\
\text { R }\end{array}$ & & & & & & & & \\
\hline & $24 \mathrm{X}-3,40$ & & cf. & & & & & & & & \\
\hline & $24 X-5,40$ & & & & & & & & & & \\
\hline & $\begin{array}{l}24 X-7,25 \\
25 X-1.50\end{array}$ & & ef. & & & & & & & & \\
\hline & $25 \times-2,39$ & & $\mathrm{R}$ & & & & & & & & \\
\hline & $\begin{array}{l}25 X-3,40 \\
25 X-5,16\end{array}$ & & & & & & & & & & \\
\hline \multirow{8}{*}{$9 \mathrm{bA}$} & $25 X-5,16$ & & & & & & & & & & \\
\hline & 138-846D- & & & & & & & & & & \\
\hline & $\begin{array}{l}26 \mathrm{X}-1,120 \\
26 \mathrm{X}-2,120\end{array}$ & & & & & & & & & & \\
\hline & $\begin{array}{l}26 \mathrm{X}-2,120 \\
26 \mathrm{X}-3,120\end{array}$ & & & & & & & & & & \\
\hline & $26 \mathrm{X}-5,120$ & & & & & & & & & & \\
\hline & $\begin{array}{l}26 X-6,120 \\
26 X-7,23\end{array}$ & & & & & & & & & & \\
\hline & $28 \mathrm{X}-3,60$ & & & & & & & & & & \\
\hline & $29 X-1,60$ & & & & & & & & & & \\
\hline \multirow[t]{3}{*}{$9 \mathrm{a}$} & $29 \times-2,60$ & & & & & & & & & & \\
\hline & & & & & & & & & & & \\
\hline & $29 \mathrm{X}-4,120$ & & & & & & & & & & \\
\hline & $\begin{array}{l}29 X-5,60 \\
29 X-5,120\end{array}$ & & & & & & & & & & \\
\hline \multirow{6}{*}{$8 b$} & $30 X-1,60$ & $\mathrm{~F}$ & & & & & & & & & \\
\hline & $30 \times-2,60$ & $\mathrm{~F}$ & & & & & & & & & \\
\hline & $30 \times-3,60$ & $\mathrm{~F}$ & & & & & & & & & \\
\hline & $30 \times-4.60$ & $\mathrm{~F}$ & & & & & & & & & \\
\hline & $\begin{array}{l}30 X-7,40 \\
31 X-4,60\end{array}$ & c & & & & & & & & & \\
\hline & $31 \times-7,40$ & $\mathrm{R}$ & & & & & & & & & \\
\hline $8 \mathrm{a}$ & $32 X-1,60$ & & $\mathrm{~F}$ & & & & & & & & \\
\hline & $\begin{array}{l}32 X-2,60 \\
32 X-3,60\end{array}$ & & & cf. & & & & & & & \\
\hline & $32 X-4,60$ & & & cf. & & & & & & & \\
\hline & $32 \times-5,60$ & & $\mathrm{R}$ & cf. & & & & & & & \\
\hline & $\begin{array}{l}32 X-5,120 \\
32 X-6,60\end{array}$ & & & $\begin{array}{l}\mathrm{C} \\
\mathrm{C}\end{array}$ & & & & & & & \\
\hline & $32 X-6,120$ & & & C & & & & & & & \\
\hline 7 & $32 \mathrm{X}-7,10$ & & cf. & $\mathrm{R}$ & & & & & & & \\
\hline & $33 \mathrm{X}-1,60$ & & & C & & & & & & & \\
\hline & $33 \times-4,60$ & & & $\mathrm{R}$ & & & & & & & \\
\hline & $\begin{array}{l}33 \mathrm{X}-4,120 \\
33 \mathrm{X}-5,60\end{array}$ & & cf. & $\mathrm{R}$ & & & & & & & \\
\hline 6 & $33 \mathrm{X}-5,120$ & & $\mathrm{R}$ & & & $\mathrm{R}$ & & & & & \\
\hline & $33 X-6,60$ & & R & & c & $\mathrm{R}$ & & & & & \\
\hline & $33 X-6,120$ & & $\mathrm{R}$ & & c & $\mathrm{R}$ & & & & & \\
\hline & $33 \times-7,34$ & & cf. & & A & & & & & & \\
\hline & $34 X-2,60$ & & $\mathrm{R}$ & & c & & & & & & \\
\hline & $34 X-4,60$ & & $\mathrm{R}$ & & C & & & & & & \\
\hline & $34 X-7.60$ & & $\mathrm{R}$ & & C & & & & & & \\
\hline & $35 \mathrm{X}-1,120$ & & $\widehat{F}$ & & C & & $\mathrm{R}$ & & & & \\
\hline & $35 X-2,120$ & & $\mathrm{~F}$ & & C & & $\mathrm{F}$ & & & & \\
\hline & $35 X-4,120$ & & F & & C & & C & & & & \\
\hline & $35 X-6,120$ & & $\mathrm{~F}$ & & C & & C & & & & \\
\hline $5 b$ & $36 \times-1.36$ & & $\mathrm{~F}$ & & A & & $\mathrm{F}$ & & & & \\
\hline & $36 \mathrm{X}-4,40$ & & $\mathrm{R}$ & & A & & & & & & \\
\hline & $36 \times-6,68$ & & $\mathrm{R}$ & & A & & $\mathrm{R}$ & & & & \\
\hline & $37 X-1.58$ & & $\hat{F}$ & & $\mathrm{c}$ & & $\ddot{R}$ & & & & \\
\hline & $37 X-3,26$ & & $\mathrm{R}$ & & C & & & & & & \\
\hline & $38 X-2,50$ & & & & c & & & & & & \\
\hline & $38 \mathrm{X}-3,50$ & & $\mathrm{R}$ & & A & & & & & & \\
\hline & $38 X-5,120$ & & & & c & & & & ef. & & \\
\hline 53 & $38 X-6,50$ & & cf. & & A & & & $\mathrm{R}$ & cf. & & \\
\hline $5 a$ & $\begin{array}{l}38 \mathrm{X}-6,120 \\
38 \mathrm{X}-\mathrm{CC}, 10\end{array}$ & & cf & & $\begin{array}{l}\mathrm{C} \\
\mathrm{C}\end{array}$ & & & $\mathrm{F}$ & $\mathrm{F}$ & & \\
\hline & $40 \times-1,40$ & & & & $\mathrm{C}$ & & & $\mathrm{R}$ & $\mathrm{F}$ & $\mathrm{F}$ & \\
\hline & $40 X-2,100$ & & & & C & & & & F & A & \\
\hline 4 & $40 X-3,120$ & & & & C & & & $\mathrm{F}$ & c & c & \\
\hline & $40 \mathrm{X}-\mathrm{CC}, 10$ & & & & C & & & C & C & C & \\
\hline & $41 X-3,60$ & & & & C & & & $\mathrm{R}$ & $\mathrm{F}$ & $\mathrm{F}$ & \\
\hline & 41 X-CC, 9 & & & & $\mathrm{C}$ & & & C & $\mathrm{F}$ & C & \\
\hline & $42 X-1.79$ & & & & A & & & C & $\mathrm{R}$ & A & $\mathrm{F}$ \\
\hline & $42 X-1.113$ & & & & A & & & c & $\mathrm{R}$ & c & $\mathrm{F}$ \\
\hline 3 & $42 \mathrm{X}-\mathrm{CC}, 12$ & & & & C & & & F & $\mathrm{R}$ & A & $\mathrm{R}$ \\
\hline & $43 \mathrm{X}-\mathrm{CC}, 3$ & & & & A & & & $\mathrm{F}$ & $\mathrm{F}$ & $A$ & $\mathrm{~F}$ \\
\hline & $44 X-3,60)$ & & & & C & & & C & $\mathrm{F}$ & A & F \\
\hline
\end{tabular}


Table 14 (continued).

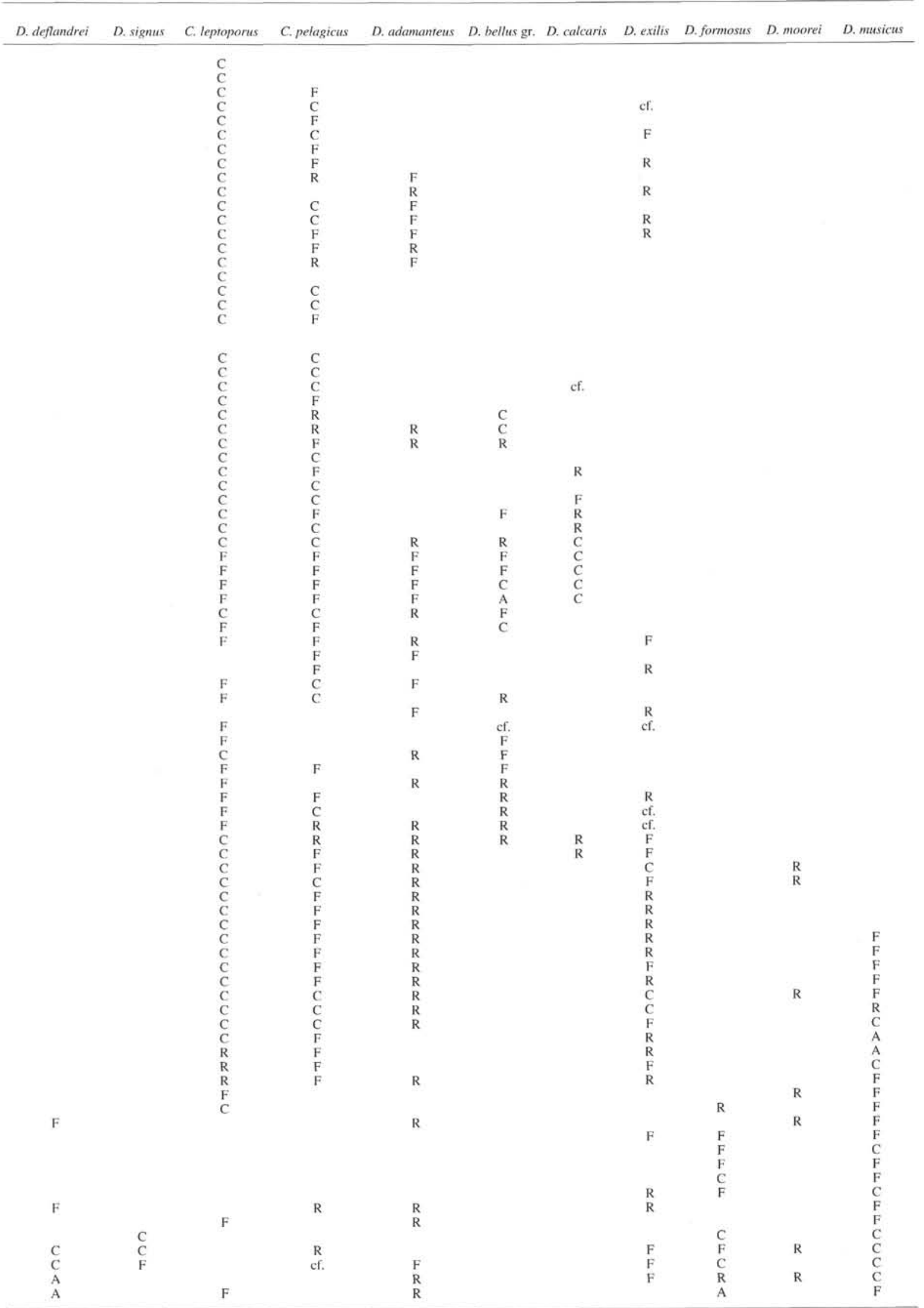


I. RAFFI, J.-A. FLORES

Table 14 (continued).

\begin{tabular}{|c|c|c|c|c|c|c|c|c|c|c|}
\hline $\begin{array}{l}\text { Zone } \\
(\mathrm{CN})\end{array}$ & $\begin{array}{l}\text { Core, section, } \\
\text { interval (cm) }\end{array}$ & D. neorectus & D. pseudovariabilis & D. variabilis & G. rotula & H. carterigr. & H. intermedia & Pontosphaera spp. & Reticulofenestra spp. & R. rotaria \\
\hline \multirow[t]{3}{*}{$10 \mathrm{a}$} & $21 \mathrm{H}-4,50$ & $\mathrm{R}$ & & $\mathrm{F}$ & $\mathrm{F}$ & $\mathrm{F}$ & & & A & C \\
\hline & $21 \mathrm{H}-4,120$ & & & $\mathrm{~F}$ & $\mathrm{~F}$ & $\mathrm{~F}$ & & & A & C \\
\hline & $21 \mathrm{H}-5.50$ & & & & $\mathrm{~F}$ & C & & & A & F \\
\hline $9 b c$ & $21 \mathrm{H}-7.50$ & & & $\mathrm{~F}$ & C & $\mathrm{F}$ & & & A & $\mathrm{F}$ \\
\hline & $22 \mathrm{H}-3,50$ & & & $\mathrm{~F}$ & & C & & & A & c \\
\hline & $23 \times-1.50$ & & & & $\mathrm{~F}$ & $\mathrm{~F}$ & & $\mathbf{R}$ & A & C \\
\hline & $23 \times-3.50$ & & & $\mathrm{~F}$ & . & $\mathrm{F}$ & & $\pi$ & A & $\mathrm{F}$ \\
\hline & $23 \mathrm{X}-3.120$ & & & $\mathrm{~F}$ & $\mathrm{~F}$ & $\mathrm{~F}$ & & & A & \\
\hline $9 \mathrm{bB}$ & $23 \mathrm{X}-4.50$ & & & $\mathrm{~F}$ & $\mathrm{~F}$ & $\mathrm{~F}$ & & & A & \\
\hline & $23 \mathrm{X}-5,50$ & & & $\mathrm{R}$ & & C & & & A & \\
\hline 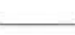 & $23 \mathrm{X}-\mathrm{CC}, 10$ & & & $\mathrm{~F}$ & $\mathrm{~F}$ & C & & $\mathrm{F}$ & A & cf. \\
\hline & $24 X-1.40$ & & & $\mathrm{R}$ & C & C & & & A & ef. \\
\hline & $24 X-3,40$ & & & & & C & & & A & \\
\hline & $24 X-5,40$ & & & $\mathrm{~F}$ & & $\mathrm{~F}$ & & & A & \\
\hline & $24 X-7.25$ & & & $\mathrm{~F}$ & $\mathrm{~F}$ & $\mathrm{~F}$ & & & A & \\
\hline & $25 \mathrm{X}-1,50$ & & & $\mathrm{~F}$ & C & C & & & A & \\
\hline & $25 \times-2,39$ & & & & $\mathrm{C}$ & $\mathrm{F}$ & & & A & \\
\hline & $25 \mathrm{X}-3.40$ & & & & C & c & & & A & \\
\hline $9 \mathrm{bA}$ & $25 X-5,16$ & & & c & C & C & & & A & \\
\hline & 138-846D- & & & & & & & & & \\
\hline & $26 \mathrm{X}-1.120$ & & & $\mathrm{~F}$ & C & C & & & A & \\
\hline & $26 \mathrm{X}-2,120$ & & & c & C & $\mathrm{F}$ & & & A & \\
\hline & $26 \mathrm{X}-3,120$ & & & c & $\mathrm{F}$ & $\mathrm{F}$ & & & A & \\
\hline & $26 \mathrm{X}-5,120$ & & & $\mathrm{~F}$ & C & $\mathrm{F}$ & & & A & \\
\hline & $26 \mathrm{X}-6,120$ & & & $\mathrm{~F}$ & $\mathrm{~F}$ & c & & & A & \\
\hline & $26 \times-7.23$ & & & $\mathrm{~F}$ & $\mathrm{~F}$ & C & & & A & \\
\hline & $28 \mathrm{X}-3.60$ & & & $\mathrm{~F}$ & $\mathrm{~F}$ & $\mathrm{~F}$ & & & A & \\
\hline & $29 \times-1,60$ & & & $\mathrm{~F}$ & C & $\mathrm{F}$ & & & A & \\
\hline $9 \mathrm{a}$ & $29 \times-2,60$ & & & & $\mathrm{~F}$ & $\mathrm{~F}$ & & C & A & \\
\hline & $29 \times-3,60$ & & & $\mathrm{~F}$ & $\mathrm{~F}$ & $\mathrm{~F}$ & & & A & \\
\hline & $29 X-4,60$ & & & C & & $\mathrm{F}$ & & & A & \\
\hline & $29 X-4,120$ & & & $\mathrm{~F}$ & & $\mathrm{~F}$ & & & A & \\
\hline & $29 \times-5,60$ & & & C & F & C & & & A & \\
\hline & $29 \mathrm{X}-5,120$ & ef. & & & $\mathrm{F}$ & C & & F & A & \\
\hline $8 \mathrm{~b}$ & $30 \mathrm{X}-1,60$ & & & $\mathrm{~F}$ & & $\mathrm{~F}$ & & & A & \\
\hline & $30 \times-2,60$ & & & $\mathrm{~F}$ & & $\mathrm{~F}$ & & & A & \\
\hline & $30 X-3,60$ & & & $F$ & & $\mathrm{~F}$ & & & A & \\
\hline & $\begin{array}{l}30 \times-4,60 \\
30 X-7,40\end{array}$ & & & $\begin{array}{l}\mathrm{A} \\
\mathrm{F}\end{array}$ & $\mathrm{R}$ & $\begin{array}{l}\mathrm{F} \\
\mathrm{F}\end{array}$ & & & $\stackrel{A}{A}$ & \\
\hline & $31 X-4,60$ & $\mathrm{R}$ & R & & $\hat{F}$ & $\mathrm{~F}$ & & & A & \\
\hline & $31 X-7,40$ & 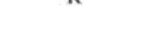 & N & $\mathrm{F}$ & $\mathrm{F}$ & C & & & A & \\
\hline $8 a$ & $32 X-1,60$ & & & & F & C & & $\mathrm{R}$ & A & \\
\hline & $32 \mathrm{X}-2,60$ & & $\mathrm{R}$ & F & $R$ & c & & & A & \\
\hline & $32 X-3,60$ & & & $\mathrm{~F}$ & $\mathrm{~F}$ & $\mathrm{~F}$ & & F & A & \\
\hline & $32 \times-4,60$ & & & C & $\mathrm{R}$ & & & $\mathrm{R}$ & A & \\
\hline & $32 X-5,60$ & & $\mathrm{~F}$ & $\mathrm{~F}$ & & & & & A & \\
\hline & $32 X-5,120$ & & & & R & C & & $\mathrm{R}$ & A & \\
\hline & $32 \mathrm{X}-6,60$ & & & F & N & $\mathrm{F}$ & & N & A & \\
\hline & $32 X-6,120$ & & F & $\mathrm{F}$ & $\mathrm{F}$ & C & & $\mathrm{R}$ & $\hat{A}$ & \\
\hline 7 & $32 \mathrm{X}-7,10$ & & & $\mathrm{~F}$ & & $\mathrm{~F}$ & & $\mathrm{R}$ & A & \\
\hline & $33 \mathrm{X}-1,60$ & & & & & $\mathrm{~F}$ & & $\mathrm{~F}$ & A & \\
\hline & $33 \times-4,60$ & & & R & & $\mathrm{F}$ & & & A & \\
\hline & $33 X-4,120$ & & & R & C & C & & & A & \\
\hline & $33 X-5,60$ & & & & $\mathrm{~F}$ & $\mathrm{~F}$ & & & A & \\
\hline 6 & $33 X-5,120$ & & & C & . & $\mathrm{F}$ & & $\mathrm{R}$ & A & \\
\hline & $33 \mathrm{X}-6,60$ & & & C & F & $\mathrm{F}$ & & $\pi$ & A & \\
\hline & $33 \mathrm{X}-6,120$ & & & C & C & $\mathrm{F}$ & & & $\hat{A}$ & \\
\hline & $33 \times-7,34$ & & & $\mathrm{~F}$ & C & $\mathrm{F}$ & & $\mathrm{R}$ & A & \\
\hline & $34 \mathrm{X}-2,60$ & & & $\mathrm{R}$ & $\mathrm{F}$ & $\mathrm{F}$ & & & c & \\
\hline & $34 X-4,60$ & & & $\mathbf{R}$ & $\mathrm{F}$ & $\mathrm{F}$ & & & C & \\
\hline & $34 \times-7,60$ & & & $\mathrm{~F}$ & $\mathrm{~F}$ & $\mathrm{~F}$ & & & C & \\
\hline & $35 X-1,120$ & & & & R & C & & & A & \\
\hline & $35 X-2,120$ & & & & $\hat{R}$ & C & & & A & \\
\hline & $35 X-4,120$ & & & & $\hat{\mathrm{R}}$ & c & & & $\hat{A}$ & \\
\hline & $35 \mathrm{X}-6,120$ & & & & $\hat{R}$ & C & & & $\hat{A}$ & \\
\hline $5 b$ & $36 \mathrm{X}-1,36$ & & & & & C & & & A & \\
\hline & $36 \times-4,40$ & & & & & C & & & A & \\
\hline & $36 \mathrm{X}-6,68$ & & & & & C & & & A & \\
\hline & $37 \mathrm{X}-1,58$ & & & & $\mathrm{R}$ & c & & & A & \\
\hline & $37 \mathrm{X}-3,26$ & & & & $\hat{F}$ & A & $\mathrm{F}$ & & A & \\
\hline & $38 \mathrm{X}-2,50$ & & & & $\mathrm{R}$ & A & & & A & \\
\hline & $38 \mathrm{X}-3.50$ & & & ef. & $\hat{R}$ & C & $\mathrm{F}$ & $\mathrm{R}$ & $\hat{A}$ & \\
\hline & $38 X-5,120$ & & & cf. & $\mathrm{F}$ & C & $\mathrm{F}$ & $\mathrm{F}$ & A & \\
\hline & $38 \times-6,50$ & & & cf. & C & C & $\mathrm{F}$ & C & A & \\
\hline $5 a$ & $38 \mathrm{X}-6,120$ & & & cf. & $\mathrm{F}$ & C & C & $\mathrm{F}$ & A & \\
\hline & $38 \mathrm{X}-\mathrm{CC}, 10$ & & & ef. & $\mathrm{F}$ & A & C & $\mathrm{F}$ & A & \\
\hline & $40 \mathrm{X}-1.40$ & & & cf. & $\mathrm{F}$ & $\mathrm{F}$ & & & $\stackrel{A}{A}$ & \\
\hline 4 & $\begin{array}{l}40 X-2,100 \\
40 X-3,120\end{array}$ & & & & & $\stackrel{A}{C}$ & & $\mathrm{R}$ & $\stackrel{A}{A}$ & \\
\hline & $40 \mathrm{X}$-CC. 10 & & & cf. & $\stackrel{c}{c}$ & $\begin{array}{l}\mathrm{C} \\
\mathrm{C}\end{array}$ & & $\begin{array}{l}\mathrm{R} \\
\mathrm{C}\end{array}$ & A & \\
\hline & $41 X-3,60$ & & & & $\mathrm{~F}$ & A & & $\mathrm{F}$ & A & \\
\hline & $41 \mathrm{X}-\mathrm{CC}, 9$ & & & cf. & & $\hat{A}$ & & $\mathrm{~F}$ & $\ddot{A}$ & \\
\hline & $42 X-1.79$ & & & & $\mathrm{R}$ & c & & $\mathrm{F}$ & A & \\
\hline & $42 X-1.113$ & & & & $\mathrm{~F}$ & C & & $\mathrm{R}$ & A & \\
\hline 3 & $42 \mathrm{X}-\mathrm{CC}, 12$ & & & & F & C & & $\mathrm{F}$ & A & \\
\hline & $43 \mathrm{X}-\mathrm{CC}, 3$ & & & ef. & R & $\mathrm{F}$ & & F & A & \\
\hline & $44 X-3,60$ & & & & & C & & C & A & \\
\hline
\end{tabular}


Table 14 (continued).

Thoracosphaera T.milowi T.serratus Umbilicosphaeraspp

$\mathrm{R}$

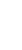

(1)

R

$\begin{array}{ll} & \mathrm{F} \\ \mathrm{R} \\ \mathrm{C} & \mathrm{C} \\ \mathrm{F} \\ \mathrm{F} \\ \mathrm{F} \\ \mathrm{C} \\ \mathrm{F}\end{array}$

R

Note: For an explanantion of the abundance and preservation codes, see the text. For genus names, see Appendix A. development of the equatorial current system during late Neogene under the influence of global climatic change. All the western transect sites are located on crust generated at about 10 to $12 \mathrm{Ma}$. The sites lie about $900 \mathrm{~km}$ west of the East Pacific Rise, with the exception of the southernmost Site 848 , which is located about $650 \mathrm{~km}$ away. Because sufficient time was saved during this part of the leg, because of favorable weather and drilling conditions, we were able to drill an extra site (Site 850) along the transect.

We report on six of the seven western transect sites. Site 848 lies south of the equator. Sites 849 and 850 lie within the equatorial divergence zone. Sites 851,852 , and 853 were drilled progressively north of the equator. We excluded from this report the northernmost Site 854 (for biostratigraphic results on nannofossils see Initial Reports volume).

\section{Site 848}

The sedimentary sequence drilled at this southernmost site of the western transect is almost $100 \mathrm{~m}$ thick, and extends to the uppermost part of middle Miocene. Excellent magnetostratigraphy was obtained in the Pleistocene-Pliocene interval (upper $46 \mathrm{~m}$ of the section) and in the lower part (the $20 \mathrm{~m}$ above the basement), which is middleupper Miocene in age.

Our biostratigraphic work is based on closely spaced samples (10$40 \mathrm{~cm}$ ) from Hole $848 \mathrm{~B}$ and from five cores of Hole 848C. Nannofossil biostratigraphic results are summarized in Figure 7, and the events are listed in Table 7. Range charts are reported in Tables 17 and 18. Nannofossils are generally abundant and have variable preservation throughout the sequence. Poor nannofossil assemblages (in terms of abundance and preservation) were observed in the lower part of the section, and correspond to an interval with low sedimentation rates (4-6 m/ m.y.) and enhanced dissolution (Mayer, Pisias, Janecek, et al., 1992).

Precise biostratigraphic assignment was difficult in some intervals because of the absence of marker species and to dissolution, which primarily effected discoasterids. Discoasterid identification was particularly vexing in the oldest sediments retrieved at Site 848 , where overgrowths made the nannofossils almost unrecognizable. Furthermore, representatives of genus Catinaster are missing, thereby further complicating the biostratigraphy. In the lower part of the section, biostratigraphic control was provided by the highest occurrence of $C$. miopelagicus and lowest occurrence of $D$. hamatus. Poor preservation of discoasterids was observed within the entire Miocene interval. Notwithstanding the strong overgrowths, we detected the lowest occurrence of $D$. neohamatus and tentatively placed the boundary CN8a/ $\mathrm{CN} 8 \mathrm{~b}$ at the lowest observed specimens of $D$. loeblichii. Even the CN8/CN9 boundary (B D. berggrenii) was placed with some difficulty, as the marker $D$. berggrenii was strongly overgrown, very rare, and scattered in the lower part of its range.

The consistent occurrence of ceratolithids in the uppermost Miocene and lower Pliocene is noteworthy. Specimens of genera Amaurolithus and Ceratolithus are unusually abundant in some levels and allowed us to define their biostratigraphic events. In the upper part of lower Pliocene (mainly within Zone CN11), we observed a strong reworking of middle-upper Miocene nannofossils such as $C$. coalitus, $M$. convallis, $D$. berggrenii, and $D$. quinqueramus. The same reworking was observed at Sites 850, 851, 852, and 853.

\section{Site 849}

The sedimentary sequence at Site 849 accumulated above a crust with an age of 11-12 Ma (Mayer, Pisias, Janecek, et al., 1992). As the site is located within the high productive equatorial divergence zone, it can provide important information about the development of oceanic conditions in this region during late Neogene. Four holes were drilled at this site, and a 320-m composite section was constructed from the recovered cores. This interval spans the time from the Pleistocene to the middle Miocene. The dominant lithology is diatom-nannofossil ooze with biosiliceous interbeds of variable thickness. The sedimentation rates at Site 849 are variable and follow a general pattern observed throughout the eastern equatorial Pacific (see Mayer, Pisias, 
Table 15. Distribution of calcareous nannofossil taxa in the Pleistocene-upper Plicene interval at Site 847.

\begin{tabular}{|c|c|c|c|c|c|c|c|c|c|c|c|c|}
\hline $\begin{array}{l}\text { Zone } \\
\text { (CN) }\end{array}$ & $\begin{array}{l}\text { Core, section, } \\
\text { interval }(\mathrm{cm})\end{array}$ & $\begin{array}{l}\text { Depth } \\
\text { (mbsf) }\end{array}$ & $\begin{array}{l}\text { Depth } \\
\text { (mcd) }\end{array}$ & Abundance & Preservation & Etching & Overgrowth & $\begin{array}{c}\text { Small } \\
\text { Gephyrocapsa }\end{array}$ & E. huxleyi & P. lacumosa & G. oceanica & Gephyrocapsa sp. 3 \\
\hline \multirow[t]{5}{*}{15} & $1 \mathrm{H}-2,120$ & 2.7 & 2.7 & A & G & 0 & 0 & $\mathrm{~F}$ & $\mathrm{~F}$ & & C & A \\
\hline & $\mathrm{IH}-3,120$ & 4.2 & 4.2 & A & G & 0 & 0 & $\mathrm{~F}$ & ? & & A & A \\
\hline & $1 \mathrm{H}-4,120$ & 5.7 & 5.7 & $\hat{A}$ & G & 0 & 0 & $\mathrm{R}$ & & & $\hat{A}$ & $\hat{\mathrm{C}}$ \\
\hline & $1 \mathrm{H}-5,15$ & 7.2 & 7.2 & $\mathrm{~A}$ & G & 0 & 0 & $\ddot{\mathrm{C}}$ & & & A & C \\
\hline & $2 \mathrm{H}-\mathrm{I}, 120$ & 7.7 & 7.83 & A & G & 0 & 0 & $\mathrm{~F}$ & & & A & $\mathrm{F}$ \\
\hline \multirow[t]{7}{*}{$14 \mathrm{~b}$} & $2 \mathrm{H}-3.120$ & 9.2 & 9.33 & A & G & 0 & 0 & A & & & $\mathrm{F}$ & \\
\hline & $2 \mathrm{H}-4,120$ & 10.7 & 10.83 & $\hat{A}$ & G & 0 & 0 & $\hat{A}$ & & & C & \\
\hline & $2 \mathrm{H}-5.50$ & 11.5 & 11.63 & $\hat{A}$ & G & 0 & 0 & A & & & $\mathrm{R}$ & \\
\hline & $2 \mathrm{H}-5,120$ & 12.2 & 12.33 & $\hat{A}$ & G & 0 & 0 & $\hat{A}$ & & & c & \\
\hline & $2 \mathrm{H}-6.51$ & 12.99 & 13.14 & A & G & 0 & 0 & $\hat{A}$ & & $\mathrm{~F}$ & $\mathrm{R}$ & \\
\hline & $2 \mathrm{H}-6,120$ & 13.68 & 13.83 & $\hat{A}$ & $G$ & 0 & 0 & A & & C & $\vec{F}$ & \\
\hline & $2 \mathrm{H}-7,24$ & 14.22 & 14.37 & $\hat{A}$ & G & 0 & 0 & $\hat{A}$ & & $\mathrm{C}$ & $\mathrm{R}$ & \\
\hline \multirow{15}{*}{$14 a$} & $3 \mathrm{H}-\mathrm{I}, 50$ & 16.5 & 16.85 & A & G & 0 & 0 & A & & C & $\mathrm{R}$ & \\
\hline & $3 \mathrm{H}-3,50$ & 19.5 & 19.85 & $\hat{A}$ & G & 0 & 0 & $\hat{A}$ & & A & $\vec{F}$ & $\mathrm{~F}$ \\
\hline & $3 \mathrm{H}-7,60$ & 26.02 & 25.85 & A & G & 0 & 0 & A & & A & $\mathrm{F}$ & C \\
\hline & $4 \mathrm{H}-1,60$ & 26.1 & 28.93 & $\mathrm{~A}$ & G & 0 & 0 & $\hat{A}$ & & A & $\mathrm{R}$ & $\mathrm{F}$ \\
\hline & $4 \mathrm{H}-1,120$ & 26.7 & 29.53 & A & G & 0 & 0 & A & & A & C & $\mathrm{F}$ \\
\hline & $4 \mathrm{H}-2,60$ & 27.6 & 30.43 & A & G & 0 & 0 & A & & A & $\mathrm{R}$ & $\mathrm{F}$ \\
\hline & $4 \mathrm{H}-2,120$ & 28.2 & 31.03 & $\hat{A}$ & G & 0 & 0 & $\hat{A}$ & & A & & $*$ \\
\hline & $4 \mathrm{H}-3.60$ & 29.1 & 31.93 & A & G & 0 & 0 & $\mathrm{~F}$ & & A & * & \\
\hline & $4 \mathrm{H}-3,120$ & 29.7 & 32.53 & $\hat{A}$ & G & 0 & 0 & C & & $\hat{A}$ & & \\
\hline & $4 \mathrm{H}-4,60$ & 30.6 & 33.43 & $\hat{A}$ & G & 0 & 0 & $\mathrm{C}$ & & $\hat{A}$ & & \\
\hline & $4 \mathrm{H}-5.60$ & 32.1 & 34.93 & $\hat{A}$ & G & 0 & 0 & $\mathrm{~F}$ & & $\hat{A}$ & & \\
\hline & $4 \mathrm{H}-7.10$ & 34.6 & 37.43 & $\hat{A}$ & G & 0 & 0 & A & & A & & \\
\hline & $4 \mathrm{H}-7,60$ & 35.1 & 37.93 & $\ddot{A}$ & G & 0 & 0 & C & & A & & \\
\hline & $5 \mathrm{H}-1.60$ & 35.6 & 38.4 & $\hat{A}$ & G & 0 & 0 & A & & $\hat{A}$ & & \\
\hline & $5 \mathrm{H}-\mathrm{I}, 120$ & 36.2 & 39.4 & A & G & 0 & 0 & C & & $\hat{A}$ & C & \\
\hline \multirow[t]{14}{*}{$13 \mathrm{~b}$} & $5 \mathrm{H}-2,60$ & 37.1 & 39.9 & $\hat{A}$ & G & 0 & 0 & C & & $\hat{\mathrm{C}}$ & C & \\
\hline & $5 \mathrm{H}-2,120$ & 37.7 & 40.5 & A & G & 0 & 0 & C & & C & A & \\
\hline & $5 \mathrm{H}-3.60$ & 38.6 & 41.4 & $\hat{A}$ & G & 0 & 0 & c & & C & C & \\
\hline & $5 \mathrm{H}-5,60$ & 41.6 & 44.4 & $\ddot{A}$ & G & 0 & 0 & A & & C & C & \\
\hline & $5 \mathrm{H}-7.40$ & 44.4 & 47.2 & C & MG & i & 0 & $\hat{A}$ & & $\mathrm{~F}$ & A & \\
\hline & $5 \mathrm{H}-\mathrm{CC}, 10$ & 45.09 & 47.89 & A & $\mathrm{G}$ & 0 & 0 & $\hat{\mathrm{C}}$ & & A & A & \\
\hline & $6 \mathrm{H}-1.60$ & 44.5 & 49.58 & A & G & 0 & 0 & A & & C & $\mathrm{F}$ & \\
\hline & $6 \mathrm{H}-1,120$ & 35.6 & 50.18 & $\hat{A}$ & G & 0 & 0 & $\hat{A}$ & & C & C & \\
\hline & $6 \mathrm{H}-2,60$ & 36.5 & $\begin{array}{l}51.08 \\
51.08\end{array}$ & $\hat{A}$ & G & 0 & 0 & $\hat{A}$ & & A & $\mathrm{R}$ & \\
\hline & $6 \mathrm{H}-3,60$ & 38 & 52.58 & $\mathrm{~A}$ & G & 0 & 0 & C & & $\ddot{A}$ & $\mathrm{~F}$ & \\
\hline & $6 \mathrm{H}-3,120$ & 38.6 & 53.18 & $\hat{A}$ & G & 0 & 0 & A & & $\hat{A}$ & $\mathrm{R}$ & \\
\hline & $6 \mathrm{H}-4,60$ & 39.5 & 54.08 & A & G & 0 & 0 & C & & A & & \\
\hline & $6 \mathrm{H}-5,60$ & 41 & 55.58 & $\hat{A}$ & $\mathrm{G}$ & 0 & 0 & $\mathrm{~F}$ & & c & & \\
\hline & $7 \mathrm{H}-1.60$ & 54.6 & 61.35 & A & $\mathrm{G}$ & 0 & 0 & C & & A & & \\
\hline \multirow[t]{11}{*}{$13 a$} & $7 \mathrm{H}-4.60$ & 59.1 & 65.85 & $\hat{A}$ & G & 0 & 0 & $\mathrm{~F}$ & & A & & \\
\hline & $7 \mathrm{H}-5.60$ & 60.6 & 67.35 & A & G & 0 & 0 & C & & $\hat{C}$ & & \\
\hline & $7 \mathrm{H}-5.120$ & 61.2 & 67.95 & A & G & 0 & 0 & $\mathrm{R}$ & & C & & \\
\hline & $7 \mathrm{H}-6.60$ & 62.1 & 68.85 & C & $\mathrm{G}$ & 0 & 0 & $\hat{R}$ & & A & & \\
\hline & $7 \mathrm{H}-6.120$ & 62.7 & 69.45 & A & G & 0 & 0 & R & & A & & \\
\hline & $7 \mathrm{H}-7.10$ & 63.1 & 69.85 & $\hat{A}$ & MG & i & 0 & $\hat{\mathrm{R}}$ & & $\hat{A}$ & & \\
\hline & $7 \mathrm{H}-7.40$ & 63.4 & 70.15 & A & MG & i & 0 & & & A & & \\
\hline & $8 \mathrm{H}-1.60$ & 64.1 & 72.28 & $\hat{A}$ & MG & i & 1 & & & A & & \\
\hline & $8 \mathrm{H}-1,120$ & 64.7 & 72.88 & $\hat{A}$ & $\mathrm{G}$ & 0 & 0 & & & A & & \\
\hline & $8 \mathrm{H}-2,60$ & 65.6 & 73.78 & $\hat{A}$ & MG & i & i & & & A & & \\
\hline & $8 \mathrm{H}-2,120$ & 66.2 & 74.38 & A & $\mathrm{G}$ & 0 & 0 & & & $\hat{A}$ & & \\
\hline $12 \mathrm{~d}$ & $8 \mathrm{H}-3,60$ & 67.1 & 75.28 & A & G & 0 & 0 & & & A & & \\
\hline & $8 \mathrm{H}-3.120$ & 67.7 & 75.88 & A & MG & i & i & & & $\hat{A}$ & & \\
\hline \multirow[t]{12}{*}{$12 \mathrm{c}$} & $8 \mathrm{H}-4,60$ & 68.6 & 76.78 & A & $\mathrm{G}$ & 0 & 0 & & & A & & \\
\hline & $8 \mathrm{H}-4,120$ & 69.2 & 77.38 & A & G & 0 & 0 & & & $\hat{A}$ & & \\
\hline & $8 \mathrm{H}-5,120$ & 70.7 & 78.88 & A & $\mathrm{G}$ & 0 & 0 & & & $\hat{A}$ & & \\
\hline & $8 \mathrm{H}-6.60$ & 71.6 & 79.78 & A & G & 0 & 0 & & & $\mathrm{~A}$ & & \\
\hline & $8 \mathrm{H}-6.120$ & 72.2 & 80.38 & $\hat{A}$ & G & 0 & 0 & & & A & & \\
\hline & $9 \mathrm{H}-1.60$ & 73.6 & $\begin{array}{l}8 ., 58 \\
83.08\end{array}$ & A & G & 0 & 0 & & & A & & \\
\hline & $9 \mathrm{H}-1,120$ & 74.2 & 83,68 & $\hat{A}$ & MG & $i$ & 0 & & & $\hat{A}$ & & \\
\hline & $9 \mathrm{H}-2,60$ & 75.1 & 84.58 & A & MG & i & 0 & & & $\hat{A}$ & & \\
\hline & $9 \mathrm{H}-2,120$ & 75.7 & 85.18 & A & MG & $i$ & 0 & & & A & & \\
\hline & $9 \mathrm{H}-3,60$ & 76.6 & 86.08 & $\hat{A}$ & MG & $i$ & 0 & & & $\hat{A}$ & & \\
\hline & $9 \mathrm{H}-3,120$ & 77.2 & 86.68 & A & MG & i & 0 & & & $\ddot{A}$ & & \\
\hline & $9 \mathrm{H}-4,60$ & 78.1 & 87.58 & $\hat{A}$ & MG & $i$ & 0 & & & $\hat{A}$ & & \\
\hline $12 \mathrm{~b}$ & $9 \mathrm{H}-5,60$ & 79.6 & 89.08 & A & MG & i & 0 & & & A & & \\
\hline & $9 \mathrm{H}-6,60$ & 81.1 & 90.58 & $\hat{A}$ & $\mathrm{G}$ & $i$ & 0 & & & $\mathrm{~A}$ & & \\
\hline & $9 \mathrm{H}-6,120$ & 81.7 & 91.18 & A & MG & $i$ & 0 & & & $\hat{A}$ & & \\
\hline & $9 \mathrm{H}-7.15$ & 82.15 & 91.63 & A & MG & $i$ & 0 & & & c & & \\
\hline $12 \mathrm{aB}$ & $9 \mathrm{H}-7,40$ & 82.4 & 91.88 & A & G & $i$ & 0 & & & A & & \\
\hline & $10 \mathrm{H}-2,60$ & 84.6 & 93.83 & A & MG & $i$ & 0 & & & $\mathrm{~A}$ & & \\
\hline & $10 \mathrm{H}-4,60$ & 87.6 & 96.83 & $\hat{A}$ & $\mathrm{G}$ & 0 & 0 & & & A & & \\
\hline
\end{tabular}

Janecek, et al., 1992). Sediment accumulation is particularly high in the latest Miocene/early Pliocene (as high as $100 \mathrm{~m} / \mathrm{m} . \mathrm{y}$.). These high rates suggest that the site was within the highly productive equatorial divergence zone by that time.

The average sample spacing for nannofossil analysis at Site 849 was $60 \mathrm{~cm}$ (Hole 849B, five cores from Hole 849C, and from one core of Hole 849D). Because sedimentation rates varied, our $60-\mathrm{cm}$ sample spacing translates in a range of temporal resolutions varying from
1 sample/0.04 m.y. to 1 sample/0.012 m.y. The nannofossil events we recognized are listed in Table 8, and the biostratigraphy is summarized in Figure 8.

Nannofossil preservation is generally moderate to good. Placoliths, mainly reticulofenestrids, are the most important component of the nannofossil assemblages. Within this group, we identified morphotypes with round outlines and central opening, labeled as "circular reticulofenestrids" in the figures (see "Taxonomic Notes" section, 
Table 15 (continued).

large

Gephyrocapsa $H$. sellii C. macintyrei D. brouweri D. triradiatus D. pentaradiatus D. surculus D. tamalis D. asymmetricus Sphenolithus R. pseudoumbilicus

$$
\begin{aligned}
& \mathrm{C} \\
& \mathrm{C} \\
& \mathrm{C} \\
& \mathrm{C} \\
& \mathrm{C}^{* *}
\end{aligned}
$$

$\begin{array}{lll}* & & \mathrm{R} \\ & & \mathrm{R} \\ \mathrm{R} & & \\ \mathrm{F} & & \\ \mathrm{F} & & \\ \mathrm{F} & & \\ \mathrm{R} & & \\ * & \mathrm{R} & \mathrm{F} \\ \mathrm{F} & \mathrm{F} & \mathrm{F} \\ \mathrm{F} & \mathrm{R} & \mathrm{F} \\ \mathrm{F} & \mathrm{F} & \end{array}$

this chapter). At Site 849, these reticulofenestrids appear when the large morphotypes $R$. pseudoumbilicus reenter the stratigraphic record in Subzone CN9bA. The distribution of "circular reticulofenestrids" has also been checked at Sites 846,847 , and 850 . At these sites, the distribution is also restricted to Subzone CN9b, up to levels corresponding to the lower range of $A$. primus and close to the lowest occurrence of A. amplificus.
Abundances of discoasterids at Site 849 fluctuate throughout the sequence and are generally low, as expected in an area of high productivity. Even ceratolithids are very rare and discontinuously distributed. Some biostratigraphic events were detected with difficulty, such as the lowest and highest occurrences of $A$. amplificus and the lowest occurrence of $D$. hamatus. Other markers are missing, such as $C$. coalitus and $C$. calyculus. 
Table 15 (continued).

\begin{tabular}{|c|c|c|c|c|c|c|c|c|c|c|c|}
\hline $\begin{array}{l}\text { Zone } \\
\text { (CN) }\end{array}$ & $\begin{array}{l}\text { Core, section, } \\
\text { interval }(\mathrm{cm})\end{array}$ & C. leptoporus & C. cristatus & C. telesmus & C. pelagicus & $D$, intercalaris & D. variabilis & G. rotula & H. carteri & H. wallichii & Pontosphaer \\
\hline \multirow[t]{5}{*}{15} & $1 \mathrm{H}-2,120$ & C & & $\mathrm{F}$ & & & & & & $\mathrm{F}$ & \\
\hline & $1 \mathrm{H}-3,120$ & A & & & & & & & & C & \\
\hline & $1 \mathrm{H}-4,120$ & A & & $\mathrm{R}$ & & & & & & c & \\
\hline & IH-5, 15 & A & $\mathrm{R}$ & $\mathrm{R}$ & & & & & $\mathrm{F}$ & C & \\
\hline & $2 \mathrm{H}-1.120$ & C & & & & & & & $\mathrm{R}$ & $\mathrm{R}$ & \\
\hline \multirow[t]{7}{*}{$14 \mathrm{~b}$} & $2 \mathrm{H}-3,120$ & C & & & & & & & & $\vec{F}$ & \\
\hline & $2 \mathrm{H}-4,120$ & A & & $\mathrm{R}$ & & & & & & $\mathrm{F}$ & \\
\hline & $2 \mathrm{H}-5,50$ & C & & $\hat{R}$ & & & & & & C & \\
\hline & $2 \mathrm{H}-5,120$ & C & & $\mathrm{R}$ & & & & & & C & \\
\hline & $2 \mathrm{H}-6,5 \mathrm{I}$ & C & & & & & & & & C & \\
\hline & $2 \mathrm{H}-6,120$ & C & & $\mathrm{R}$ & & & & & & C & \\
\hline & $2 \mathrm{H}-7.24$ & C & & & & & & & & C & \\
\hline \multirow[t]{15}{*}{$14 a$} & $3 \mathrm{H}-1,50$ & C & & & & & & & & & \\
\hline & $3 \mathrm{H}-3,50$ & C & & & & & & & & C & C \\
\hline & $3 \mathrm{H}-7,60$ & C & $\mathrm{F}$ & & & & & & $\mathrm{F}$ & $\mathrm{F}$ & C \\
\hline & $4 \mathrm{H}-1,60$ & C & $\mathrm{R}$ & & & & & & $\mathrm{F}$ & $\mathrm{R}$ & \\
\hline & $4 \mathrm{H}-1,120$ & C & & & & & & & $\mathrm{F}$ & & \\
\hline & $4 \mathrm{H}-2.60$ & C & & & & & & & C & & $\mathrm{F}$ \\
\hline & $4 \mathrm{H}-2,120$ & A & $\mathrm{R}$ & & & & & & C & & $\mathrm{R}$ \\
\hline & $4 \mathrm{H}-3,60$ & C & & & & & & & C & $\mathrm{F}$ & $\mathrm{F}$ \\
\hline & $4 \mathrm{H}-3,120$ & C & & & & & & & $\mathrm{F}$ & & \\
\hline & $4 \mathrm{H}-4,60$ & C & & & & & & & C & $\mathrm{R}$ & \\
\hline & $4 \mathrm{H}-5,60$ & C & & & & & & & C & & $\mathrm{F}$ \\
\hline & $4 \mathrm{H}-7,10$ & A & & & & & & & C & & \\
\hline & $4 \mathrm{H}-7,60$ & C & & & & & & & $\mathrm{F}$ & & $\mathrm{F}$ \\
\hline & $5 \mathrm{H}-1,60$ & C & & & & & & & C & & $\mathrm{F}$ \\
\hline & $5 \mathrm{H}-1,120$ & C & & & & & & & C & & \\
\hline \multirow[t]{14}{*}{$13 \mathrm{~b}$} & $5 \mathrm{H}-2,60$ & C & & & & & & & C & & $\mathrm{F}$ \\
\hline & $5 \mathrm{H}-2,120$ & C & & & & & & & C & & $\mathrm{F}$ \\
\hline & $5 \mathrm{H}-3,60$ & c & $\mathrm{R}$ & $\mathrm{R}$ & $\mathrm{R}$ & & & & C & & C \\
\hline & $5 \mathrm{H}-5,60$ & C & & & $\begin{array}{l}\mathrm{K} \\
\mathrm{R}\end{array}$ & & & & $\mathrm{F}$ & & $\mathrm{F}$ \\
\hline & $5 \mathrm{H}-7,40$ & $\mathrm{~F}$ & & & & & & & $\mathrm{~F}$ & & \\
\hline & $5 \mathrm{H}-\mathrm{CC} .10$ & $\mathrm{~F}$ & $\mathrm{R}$ & $\mathrm{R}$ & & & & & C & & \\
\hline & $6 \mathrm{H}-1,60$ & C & & & $R$ & & & & C & & $\mathrm{F}$ \\
\hline & $6 \mathrm{H}-1,120$ & C & & & & & & & $\mathrm{F}$ & & \\
\hline & $6 \mathrm{H}-2,60$ & C & $\mathrm{R}$ & $\mathrm{R}$ & $\mathrm{R}$ & & & & C & & \\
\hline & $6 \mathrm{H}-3.60$ & C & $\hat{\mathrm{F}}$ & $\hat{R}$ & & & & & C & & C \\
\hline & $6 \mathrm{H}-3,120$ & C & $\mathrm{F}$ & $\mathrm{F}$ & $\mathrm{R}$ & & & & C & & \\
\hline & $6 \mathrm{H}-4,60$ & C & C & & $\mathrm{F}$ & & & & C & & $\mathrm{R}$ \\
\hline & $6 \mathrm{H}-5,60$ & C & $\mathrm{F}$ & & C & & & & C & & F \\
\hline & $7 \mathrm{H}-1,60$ & c & $\mathrm{R}$ & & $\mathrm{F}$ & & & & C & & $\mathrm{F}$ \\
\hline \multirow{11}{*}{$13 \mathrm{a}$} & $7 \mathrm{H}-4,60$ & C & $\hat{R}$ & & $\mathrm{~F}$ & & & & C & & $\mathrm{F}$ \\
\hline & $7 \mathrm{H}-5,60$ & C & $\mathrm{F}$ & & $\mathrm{F}$ & & & & C & & \\
\hline & $7 \mathrm{H}-5,120$ & C & $\mathrm{R}$ & & C & & & & C & & $\mathrm{F}$ \\
\hline & $7 \mathrm{H}-6,60$ & C & & & $\mathrm{F}$ & & & & $\mathrm{F}$ & & C \\
\hline & $7 \mathrm{H}-6,120$ & C & R & & C & & & & $\mathrm{R}$ & & $\mathrm{R}$ \\
\hline & $7 \mathrm{H}-7,10$ & C & & & $\mathrm{F}$ & & & & C & & R \\
\hline & $7 \mathrm{H}-7,40$ & C & $\mathrm{F}$ & & C & & & & C & $\mathrm{R}$ & R \\
\hline & $8 \mathrm{H}-1,60$ & C & $\mathrm{F}$ & & C & $*$ & & & A & & $\mathrm{R}$ \\
\hline & $8 \mathrm{H}-\mathrm{I}, 120$ & C & $\mathrm{F}$ & & A & * & & & C & & $\mathrm{F}$ \\
\hline & $8 \mathrm{H}-2,60$ & C & $\mathrm{F}$ & & C & * & & & C & & $\mathrm{R}$ \\
\hline & $8 \mathrm{H}-2,120$ & C & & & C & & & & C & & \\
\hline $12 \mathrm{~d}$ & $8 \mathrm{H}-3,60$ & C & & & C & & & & C & & $\mathrm{F}$ \\
\hline+ & $8 \mathrm{H}-3,120$ & C & F & & c & & & & C & & \\
\hline \multirow[t]{12}{*}{$12 \mathrm{c}$} & $8 \mathrm{H}-4,60$ & C & & & C & & & & C & & \\
\hline & $8 \mathrm{H}-4,120$ & A & & & C & $\mathrm{R}$ & & & C & & \\
\hline & $8 \mathrm{H}-5,120$ & A & & & A & & & & C & & $\mathrm{R}$ \\
\hline & $8 \mathrm{H}-6,60$ & C & $\mathrm{F}$ & & C & & & & C & & $\mathrm{F}$ \\
\hline & $8 \mathrm{H}-6,120$ & C & & & C & & & & C & & $\mathrm{F}$ \\
\hline & $9 \mathrm{H}-1,60$ & C & $\mathrm{F}$ & & C & & & & C & & $\mathrm{F}$ \\
\hline & $9 \mathrm{H}-1,120$ & A & $\mathrm{R}$ & & A & & & & C & & $\mathrm{R}$ \\
\hline & $9 \mathrm{H}-2,60$ & $\hat{\mathrm{C}}$ & $\mathrm{R}$ & & $\hat{\mathrm{F}}$ & & & $\mathrm{F}$ & $\mathrm{F}$ & & $\mathrm{C}$ \\
\hline & $9 \mathrm{H}-2,120$ & A & $\mathrm{F}$ & & A & & & & A & & \\
\hline & $9 \mathrm{H}-3,60$ & C & $\mathrm{R}$ & & $\vec{F}$ & & * & $\mathbf{R}$ & A & & $\mathrm{F}$ \\
\hline & $9 \mathrm{H}-3,120$ & A & $\mathrm{R}$ & & A & * & & $\mathrm{R}$ & c & & $\mathrm{F}$ \\
\hline & $9 \mathrm{H}-4,60$ & c & F & & C & $\mathrm{R}$ & & $\widehat{F}$ & C & & $\mathrm{F}$ \\
\hline $12 \mathrm{~b}$ & $9 \mathrm{H}-5,60$ & C & $\mathrm{R}$ & & $\mathrm{F}$ & $\hat{R}$ & * & C & C & & $\mathrm{F}$ \\
\hline & $9 \mathrm{H}-6,60$ & C & & & ${ }_{\mathrm{C}}^{\mathrm{F}}$ & $\begin{array}{l}\mathrm{K} \\
\mathrm{R}\end{array}$ & & $\mathrm{F}$ & C & & $\mathrm{F}$ \\
\hline & $9 \mathrm{H}-6,120$ & A & $\mathrm{R}$ & & C & $\hat{R}$ & & & $\mathrm{C}$ & & $\mathrm{F}$ \\
\hline & $9 \mathrm{H}-7,15$ & A & $\mathrm{F}$ & & A & $\ddot{R}$ & & & A & & $\mathrm{F}$ \\
\hline $12 \mathrm{aB}$ & $9 \mathrm{H}-7.40$ & C & $\mathrm{F}$ & & C & $\mathrm{F}$ & & $\mathrm{R}$ & C & & $\mathrm{F}$ \\
\hline & $10 \mathrm{H}-2.60$ & C & $\mathrm{F}$ & & $\mathrm{F}$ & C & & $\mathrm{F}$ & C & & $\mathrm{F}$ \\
\hline & $10 \mathrm{H}-4,60$ & c & $\mathrm{F}$ & & $\mathrm{F}$ & $\mathrm{F}$ & & $\mathrm{F}$ & $\mathrm{F}$ & & $\mathrm{R}$ \\
\hline
\end{tabular}

Within the oldest sediments retrieved at Site 849 , we recorded the final range of common D. kugleri. This finding allows us to assign the lowermost part of the sequence to the middle part of Subzone CN5b.

\section{Site 850}

Site 850 was drilled just north of the equator, halfway between Sites 849 and 851 . This location is suitable for investigating the narrow equatorial divergence zone. Unfortunately, the site was only drilled once, because of time pressures. The hole was cored with the $\mathrm{APC}$ to $74 \mathrm{mbsf}$ and then cored with the XCB from there to the basement. The $400-\mathrm{m}$ section recovered from this site spans the time interval from the Pleistocene to the middle Miocene. A brief interval with a strong magnetic signal was identified between 60 and $75 \mathrm{mcd}$, spanning the Subchron 2An.1r (Kaena) to the 2An-2Ar (GaussGilbert) boundary. The sedimentary section at Site 850 represents a 
Table 15 (continued).

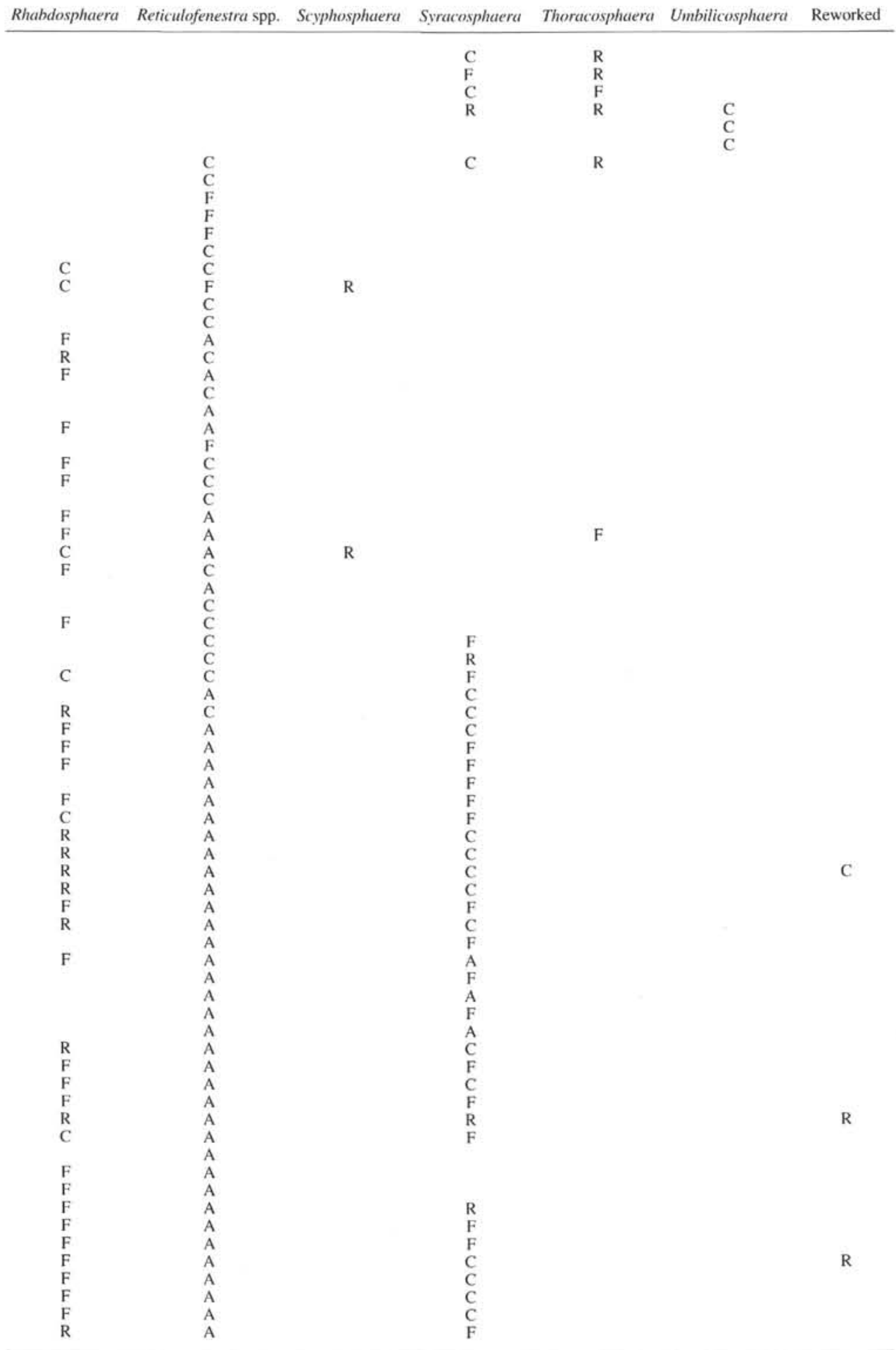

Notes: For an explanation of the abundance and preservation codes, see text. For genus names, see Appendix A. Single asterisk (*) $=$ one specimen observed.

single lithologic unit of radiolarian and diatom-nannofossil ooze, with several layers of laminated diatom ooze and thinly bedded chert in the lower part of the section. The sedimentation pattern is similar to that reconstructed at Site 849 (Mayer, Pisias, Janecek, et al., 1992).

We took 6 to 12 samples per core from Hole 850B for nannofossil analysis. The resulting biostratigraphy is shown in Figure 9, and the nannofossil events are listed in Table 9. Nannofossils are abundant throughout the sequence and their preservation varies. Placoliths generally dominate the assemblages. Discoasterids and ceratolithids fluctuate in abundance and are very rare or absent in some intervals, as was seen at Site 849. A detailed nannofossil biostratigraphy in the upper Miocene and Pliocene intervals was difficult to generate on 
Table 16. Distribution of calcareous nannofossil taxa in the lower Pliocene-upper Miocene interval at Site 847.

\begin{tabular}{|c|c|c|c|c|c|c|c|c|c|c|c|c|c|c|c|c|c|}
\hline Zone $(\mathrm{CN})$ & $\begin{array}{l}\text { Core, section, } \\
\text { interval }(\mathrm{cm})\end{array}$ & $\begin{array}{l}\text { Depth } \\
\text { (mbsf) }\end{array}$ & $\begin{array}{l}\text { Depth } \\
\text { (mcd) }\end{array}$ & Abundance & Preservation & Etching & Overgrowth & 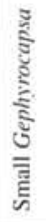 & $\begin{array}{l}\vdots \\
\Sigma \\
\Sigma\end{array}$ & $\frac{\pi}{3}$ & 彦 & $\frac{1}{0}$ & 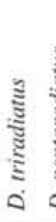 & 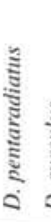 & 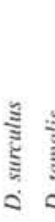 & 言 & 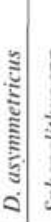 \\
\hline & $12 \mathrm{H}-1.120$ & 102.7 & 115.73 & A & G & 0 & 0 & & $*$ & C & C C & C & & C R & R $R$ & $\mathrm{R}$ : & * \\
\hline $12 \mathrm{aB}$ & $12 \mathrm{H}-2.60$ & 103.6 & 116.63 & $\mathrm{~A}$ & G & 0 & 0 & & & C & C C & C & & $\mathrm{F} \quad \mathrm{F}$ & $\mathrm{F}$ & $* \mathrm{R}$ & $\mathrm{R}$ \\
\hline & $12 \mathrm{H}-2.120$ & 104.2 & 117.23 & A & MG & 1 & 0 & & & C & $\mathrm{R} \quad \mathrm{C}$ & C & * & * & & & * \\
\hline & $12 \mathrm{H}-3,60$ & 105.1 & 118.13 & A & MG & $i$ & $i$ & & & A & C C & C & & $\mathrm{F} \quad \mathrm{F}$ & $\mathrm{F}$ & & $*$ \\
\hline & $12 \mathrm{H}-3,120$ & 105.7 & 118.73 & $\mathrm{~A}$ & G & 0 & 0 & $\mathrm{~F}$ & $\mathrm{R}$ & C & A $R$ & $\mathrm{R}$ & & $\mathrm{F}$ & & & $=\mathrm{C}$ \\
\hline $12 \mathrm{aA}$ & $12 \mathrm{H}-4,60$ & 106.6 & 119.63 & A & G & 0 & 0 & $\mathrm{R}$ & $\mathrm{R}$ & C & C F & $\mathrm{F}$ & & $\mathrm{R} R$ & R & & C \\
\hline & $12 \mathrm{H}-4.120$ & 107.2 & 120.23 & $\mathrm{~A}$ & G & 0 & 0 & $\mathrm{~F}$ & $\mathrm{R}$ & $\mathrm{F}$ & $\mathrm{F} \quad \mathrm{F}$ & $\mathrm{F}$ & & * & & & $\mathrm{R} \quad \mathrm{R}$ \\
\hline & $12 \mathrm{H}-5,60$ & 108.1 & 121.13 & A & G & 0 & 0 & $\mathrm{R}$ & & C & $\mathrm{F} \quad \mathrm{R}$ & $\mathrm{R}$ & & $\mathrm{R} R$ & $\mathrm{R}$ & & $\mathrm{C}$ \\
\hline & $12 \mathrm{H}-5,120$ & 108.7 & 121.73 & A & G & 0 & 0 & $\mathrm{~F}$ & & $\mathrm{~F}$ & A C & C : & $* \quad$ & $* \mathrm{R}$ & $\mathrm{R}$ * & $* \quad *$ & $* C$ \\
\hline & $12 \mathrm{H}-6.63$ & 109.63 & 122.66 & $\mathrm{~A}$ & G & 0 & 0 & $\mathrm{R}$ & & $\mathrm{F}$ & $\mathrm{F} \quad \mathrm{R}$ & $\mathrm{R}$ & & & $\mathrm{R}$ & & $* \mathrm{C}$ \\
\hline & $12 \mathrm{H}-6.120$ & 110.23 & 123.26 & $\mathrm{~A}$ & G & 0 & 0 & $\mathrm{R}$ & $\mathrm{R}$ & $\mathrm{R}$ & A $R$ & R & & & $*$ & & A \\
\hline & $12 \mathrm{H}-7.14$ & 110.67 & 123.7 & A & MG & 1 & 0 & $\mathbf{R}$ & & & $\mathrm{F} \quad \mathrm{C}$ & C & & $\mathrm{R} \quad \mathrm{R}$ & $\mathrm{R}$ & & \begin{tabular}{l|l}
$\mathrm{R}$ & $\mathrm{F}$
\end{tabular} \\
\hline & $12 \mathrm{H}-7.60$ & 111.13 & 124.16 & A & G & 0 & 0 & & & $\mathrm{R}$ & $\mathrm{F} \quad \mathrm{F}$ & $\mathrm{F}$ & & $\mathrm{F} \quad \mathrm{R}$ & R & & $=8$ \\
\hline & $13 \mathrm{H}-1.70$ & 111.7 & 125.7 & A & G & 0 & 0 & & & & $\mathrm{~F} \quad \mathrm{~F}$ & $\mathrm{~F}$ & & $\mathrm{R} \quad \mathrm{R}$ & R & & $\mathrm{F} C$ \\
\hline & $13 \mathrm{H}-2,60$ & 11.3 .1 & 127.1 & A & G & 0 & 0 & & & & $\mathrm{~F} \quad \mathrm{C}$ & C & & & $\mathbf{R}$ & & $\mathrm{F} \quad \mathrm{C}$ \\
\hline $11 \mathrm{~B}$ & $13 \mathrm{H}-4.150$ & 117 & 131 & A & $\mathrm{G}$ & 0 & 0 & & & & $\mathrm{~F} \quad \mathrm{~F}$ & $\mathrm{~F}$ & & & & & $* A$ \\
\hline & $13 \mathrm{H}-5.60$ & 117.6 & 131.6 & A & G & 0 & I & & & & $\mathrm{F} \quad \mathrm{F}$ & $\mathrm{F}$ & & $\mathrm{F} \quad \mathrm{R}$ & $\mathrm{R}$ & & $\mathrm{F} \quad \mathrm{C}$ \\
\hline & $14 \mathrm{H}-1.60$ & 121.1 & 136.58 & A & MG & I & 1 & & & & $\mathrm{~F} \quad \mathrm{C}$ & C & & $R \quad F$ & $F$ & & $\mathrm{C}$ \\
\hline & $14 \mathrm{H}-2,124$ & 123.24 & 138.72 & $\mathrm{~A}$ & G & 0 & 0 & & $\mathrm{R}$ & & $\mathrm{F} \quad \mathrm{F}$ & $\mathrm{F} R$ & $R \quad F$ & $\vec{F} \quad R$ & R & & A \\
\hline & $14 \mathrm{H}-3.60$ & 124.1 & 139.58 & A & G & 0 & 0 & & & & $\mathrm{~F} \quad \mathrm{~F}$ & $\mathrm{~F}$ & & $\mathrm{~F} \quad \mathrm{~F}$ & $\mathrm{~F}$ & & $\mathrm{~F} \quad \mathrm{~A}$ \\
\hline & $14 \mathrm{H}-3.124$ & 124.74 & 140.22 & A & G & 0 & 0 & & & & C C & C $R$ & $\mathrm{R}$ & & $\mathbf{R}$ & & $\mathrm{F}$ A \\
\hline & $14 \mathrm{H}-4,124$ & 126.24 & 141.72 & A & G & 0 & 0 & & & & C $\mathrm{F}$ & $\mathrm{F}$ & & & F & & A \\
\hline--- & $14 \mathrm{H}-5,60$ & 127.1 & 142.58 & A & G & 0 & 0 & & & & $\mathrm{~F} \quad \mathrm{~A}$ & A & & $\mathrm{F} \quad \mathrm{F}$ & $\mathrm{F}$ & & $\mathrm{F} \quad \mathrm{C}$ \\
\hline$-11 a^{2}-$ & $14 \mathrm{H}-5,124$ & 127.74 & 143.22 & A & MG & 1 & 1 & & & & A F & $\mathrm{F}$ & & C $\mathrm{R}$ & $\mathrm{R}$ & & A \\
\hline & $14 \mathrm{H}-6,60$ & 128.6 & 144.08 & $\mathrm{~A}$ & MG & i & $i$ & & & & $\mathrm{~F} \quad \mathrm{C}$ & C & & $F \quad F$ & F & & $* A$ \\
\hline & $14 \mathrm{H}-6.124$ & 129.24 & 144.72 & A & M & i & 2 & & & & C $\mathrm{F}$ & $\mathrm{F}$ & & $*$ & & & A \\
\hline & $14 \mathrm{H}-7,50$ & 130 & 145.48 & A & MG & i & 1 & & & & F F & $\mathrm{F}$ & & $F \quad F$ & F & & F \\
\hline & $15 \mathrm{H}-2,60$ & 132.1 & 148.05 & A & MG & i & $i$ & & & & F C & C & & R F & $\mathrm{F}$ & & $\mathrm{F}$ \\
\hline & $15 \mathrm{H}-4,60$ & 135.1 & 151.05 & $\mathrm{~A}$ & MG & i & $i$ & & & & $\mathrm{~F} \quad \mathrm{~F}$ & $\mathrm{~F}$ & & $\mathrm{~F} \quad \mathrm{C}$ & C & & $\mathrm{F}$ \\
\hline & $15 \mathrm{H}-6.62$ & 138.12 & 154.07 & A & MG & i & $i$ & & & & C $\mathrm{F}$ & $\mathrm{F}$ & & R F & $\mathrm{F}$ & & F \\
\hline & $15 \mathrm{H}-7.49$ & 139.49 & 155.44 & $\mathrm{~A}$ & MG & 0 & 2 & & & & $\mathrm{R} \quad \mathrm{C}$ & C & & C $\mathrm{F}$ & $\mathrm{F}$ & & A \\
\hline & $16 \mathrm{H}-1,140$ & 140.9 & 157.35 & $\mathrm{~A}$ & MG & 0 & 2 & & & & $\mathrm{~F} \quad \mathrm{~A}$ & A & & C C & C & & C \\
\hline $10 \mathrm{c}$ & $16 \mathrm{H}-5.60$ & 144.6 & 161.05 & A & MG & 1 & 1 & & & & $F \quad F$ & F & & $F \quad F$ & $\mathrm{~F}$ & & C \\
\hline & $16 \mathrm{H}-6,60$ & 146.1 & 162.55 & $\mathrm{~A}$ & MG & 0 & i & & & & $\mathrm{F} \quad \mathrm{F}$ & $\mathrm{F}$ & & R & R & & C \\
\hline & $17 \mathrm{H}-1,60$ & 146.4 & 165.75 & $\mathrm{~A}$ & MG & I & 2 & & & & $\mathrm{~F} \quad \mathrm{~F}$ & $\mathrm{~F}$ & & $\mathrm{~F} \quad \mathrm{~F}$ & $\mathrm{~F}$ & & C \\
\hline & $17 \mathrm{H}-2,60$ & 147.9 & 167.25 & A & MG & I & 1 & & & & $F \quad F$ & F & & $\mathrm{F} \quad \mathrm{F}$ & $F$ & & A \\
\hline & $17 \mathrm{H}-3.60$ & 149.4 & 168.75 & $\mathrm{~A}$ & G & 0 & 0 & & & & $\mathrm{~F} \quad \mathrm{~F}$ & $\mathrm{~F}$ & & $\mathrm{~F} \quad \mathrm{~F}$ & $\mathrm{~F}$ & & c \\
\hline & $17 \mathrm{H}-4,60$ & 150.9 & 170.25 & $\mathrm{~A}$ & $\mathrm{G}$ & 0 & 1 & & & & $\mathrm{~F} \quad \mathrm{~F}$ & $\mathrm{~F}$ & & $\mathrm{~F} \quad \mathrm{~F}$ & $\mathrm{~F}$ & & A \\
\hline & $17 \mathrm{H}-5.60$ & 152.4 & 171.75 & A & G & 0 & $i$ & & & & $\mathrm{~F} \quad \mathrm{~F}$ & $\mathrm{~F}$ & & $\mathrm{R}$ & $\mathrm{F}$ & * & $* \quad F$ \\
\hline & $17 \mathrm{H}-5,123$ & 153.03 & 172.38 & $\mathrm{~A}$ & $M$ & I & 2 & & & & C C & C & & & R & & C \\
\hline & $17 \mathrm{H}-6,60$ & 153.9 & 173.25 & A & MG & i & $i$ & & & & $\mathrm{~F} \quad \mathrm{~F}$ & $\mathrm{~F}$ & & $R \quad F$ & $\mathrm{~F}$ & & C \\
\hline & $17 \mathrm{H}-6.123$ & 154.53 & 173.88 & A & MG & 1 & 2 & & & & C C & C & & & C & & A \\
\hline & $17 \mathrm{H}-7.154 .85$ & 174.2 & A & $M G$ & 1 & i & & & & $\mathrm{F}$ & $F$ & & $R \quad F$ & $\mathrm{~F}$ & & $* \mathrm{C}$ & C \\
\hline & $18 \mathrm{H}-2.60$ & 157.6 & 176.95 & A & MG & i & 1 & & & & $\mathrm{~F} \quad \mathrm{~F}$ & $\mathrm{~F}$ & & $\mathrm{~F} \quad \mathrm{~F}$ & $\mathrm{~F}$ & & $* \mathrm{C}$ \\
\hline $10 \mathrm{~b}$ & $18 \mathrm{H}-3,60$ & 159.1 & 178.45 & A & MG & 1 & 1 & & & & C $\mathrm{F}$ & $\mathrm{F}$ & & $F \quad F$ & $\mathrm{~F}$ & & ${ }^{*} \mathrm{C}$ \\
\hline & $18 \mathrm{H}-4.60$ & 160.6 & 179.95 & $\mathrm{~A}$ & MG & 0 & 1 & & & & $\mathrm{~F} \quad \mathrm{C}$ & C & & & $\mathrm{F}$ & & A \\
\hline & $18 \mathrm{H}-5,60$ & 162.1 & 181.45 & A & MG & $i$ & $i$ & & & & C $\mathrm{F}$ & $\mathrm{F}$ & & & $\mathrm{F}$ & & C \\
\hline & $18 \mathrm{H}-6,60$ & 163.6 & 182.95 & A & MG & 1 & 1 & & & & $\mathrm{~F} \quad \mathrm{~A}$ & A & & & $\mathrm{F}$ & & c \\
\hline & $18 \mathrm{H}-7.3$ & 164.53 & 183.88 & A & G & 0 & 1 & & & & F $\quad C$ & C & & $\mathrm{F} \quad \mathrm{R}$ & $\mathbf{R}$ & & $\mathrm{R}$ A \\
\hline & $18 \mathrm{H}-7,15$ & 164.65 & 184 & $\mathrm{~A}$ & MG & 0 & 2 & & & & C C & C & & & F & & C \\
\hline & $19 \mathrm{H}-1.60$ & 165.3 & 184.65 & A & MG & 1 & 2 & & & & $\mathrm{~F} \quad \mathrm{~F}$ & $\mathrm{~F}$ & & & F & & c \\
\hline & $19 \mathrm{H}-1,123$ & 165.93 & 185.28 & A & G & 0 & 0 & & & & $R \quad F$ & $\mathrm{~F}$ & & $\mathrm{~F} \quad \mathrm{R}$ & $\mathrm{R}$ & & $* \quad C$ \\
\hline & $19 \mathrm{H}-2,123$ & 167.43 & 186.78 & A & MG & $i$ & 1 & & & & $\mathrm{C} F$ & $\mathrm{~F}$ & & C R & $\ddot{R}$ & & C \\
\hline $10 \mathrm{a}$ & $19 \mathrm{H}-5,123$ & 168.93 & 188.28 & A & MG & 0 & 2 & & & & R C & C & & C $\mathrm{F}$ & $\mathrm{F}$ & & A \\
\hline & $19 \mathrm{H}-7.5$ & 169.25 & 188.6 & A & MG & 0 & 2 & & & & $\mathrm{C} \quad \mathrm{F}$ & $\mathrm{F}$ & & $\mathrm{F} \quad \mathrm{R}$ & R & & A \\
\hline & $19 \mathrm{H}-7.40$ & 169.6 & 188.95 & A & MG & 1 & $i$ & & & & $\mathrm{~F} \quad \mathrm{~F}$ & $\mathrm{~F}$ & & $\mathrm{R}$ & $\mathrm{F}$ & & C \\
\hline & $20 X-1,60$ & 174.5 & 193.85 & A & MG & I & 2 & & & & & F & & & $\mathrm{F}$ & & A \\
\hline & $20 X-1,122$ & 175.12 & 194.47 & A & MG & 0 & 2 & & & & R C & C & & $\mathrm{F} \quad \mathrm{C}$ & C & & A \\
\hline & $20 \times-2,60$ & 176 & 195.35 & A & MG & 1 & $i$ & & & & & $\mathrm{R}$ & & $\mathrm{R}$ & $\mathrm{F}$ & & A \\
\hline & $20 \mathrm{X}-2,122$ & 176.62 & 195.97 & A & G & 0 & 0 & & & & C & & & 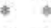 & * & & A \\
\hline & $20 X-3,60$ & 177.5 & 196.85 & A & MG & $i$ & 1 & & & & $\mathrm{~F} \quad \mathrm{~F}$ & $\mathrm{~F}$ & & $\mathrm{R} R$ & $\mathrm{R}$ & & C \\
\hline & $20 \times-3.93$ & 177.83 & 197.18 & A & G & 0 & $i$ & & & & F C & C & & $\mathrm{R} \quad \mathrm{C}$ & $\mathrm{C}$ & & C \\
\hline & $20 \times-4,60$ & 179.01 & 198.36 & A & MG & 1 & $i$ & & & & & & & $\mathrm{R} \quad \mathrm{R}$ & $\mathrm{R}$ & & C \\
\hline & $20 X-4.123$ & 179.64 & 198.99 & A & MG & i & i & & & & $\mathrm{R} \quad \mathrm{C}$ & $\mathrm{C}$ & & C C & C & & A \\
\hline & $20 X-5,60$ & 180.51 & 199.86 & A & MG & $i$ & 2 & & & & & $\bar{R}$ & & & $\mathrm{~F}$ & & C \\
\hline & $20 X-6,60$ & 182,01 & 201.36 & A & MG & $i$ & 2 & & & & $\mathrm{~F} \quad \mathrm{~F}$ & $\mathrm{~F}$ & & & $\mathrm{R}$ & & C \\
\hline & $21 \times-1.60$ & 184.1 & 203.45 & A & MG & i & 1 & & & & & $\mathrm{R}$ & & & $\mathrm{F}$ & & A \\
\hline & $21 X-2.60$ & 185.6 & 204.95 & A & G & i & 0 & & & & $\mathrm{~F} \quad \mathrm{R}$ & $\mathrm{R}$ & & & $\mathrm{F}$ & & A \\
\hline & $21 X-3.60$ & 187.1 & 206.45 & A & M & 0 & 2 & & & & $\mathrm{R}$ ef & ef & & & & & A. \\
\hline & $21 \times-4.60$ & 188.6 & 207.95 & A & G & 0 & 1 & & & & F $\quad R$ & $\mathrm{R}$ & & & $\mathrm{F}$ & & A \\
\hline & $21 X-5.60$ & 190.1 & 209.45 & A & MG & 0 & 2 & & & & $\mathrm{~F} \quad \mathrm{R}$ & $\mathrm{R}$ & & & cf & & A \\
\hline $9 b$ & $21 X-6.60$ & 191.6 & 210.95 & A & MG & 0 & 2 & & & & $\mathrm{~F} \quad \mathrm{R}$ & $\mathrm{R}$ & & & $\mathrm{F}$ & & A \\
\hline & $21 \times-7.40$ & 192.9 & 212.25 & A & MG & 0 & 2 & & & & $\mathrm{~F} \quad \mathrm{R}$ & $\mathrm{R}$ & & & $\mathrm{F}$ & & A \\
\hline & $22 X-1,60$ & 193.8 & 213.15 & A & $M$ & 0 & 2 & & & & $\mathrm{R} \quad \mathrm{R}$ & $\ddot{R}$ & & & cf & & A \\
\hline & $22 X-2,123$ & 195.93 & 215.28 & A & MG & 0 & 2 & & & & $\mathrm{~F} \quad \mathrm{C}$ & C & & & & & A \\
\hline & $22 \times-3,60$ & 196.8 & 216.15 & A & G & 0 & i & & & & & $\mathrm{R}$ & & & $\mathrm{R}$ & & A \\
\hline & $22 X-4,123$ & 198.93 & 218.28 & A & M & 1 & 2 & & & & C $\mathrm{R}$ & $\mathrm{R}$ & & & $\mathrm{R}$ & & A \\
\hline & $22 X-5,60$ & 199.8 & 219.15 & A & MG & 0 & 2 & & & & $\mathrm{~F} \quad \mathrm{~F}$ & $\mathrm{~F}$ & & & $\mathrm{~F}$ & & A \\
\hline & $22 X-6,123$ & 201.93 & 221.28 & A & MG & 0 & $\overline{2}$ & & & & $\mathrm{R}$ ct & cf & & & $*$ & & A \\
\hline & $23 X-1,60$ & 203.4 & 222.75 & A & MG & 0 & 2 & & & & F & cf & & & $\mathrm{F}$ & & A \\
\hline
\end{tabular}


Table 16 (continued).

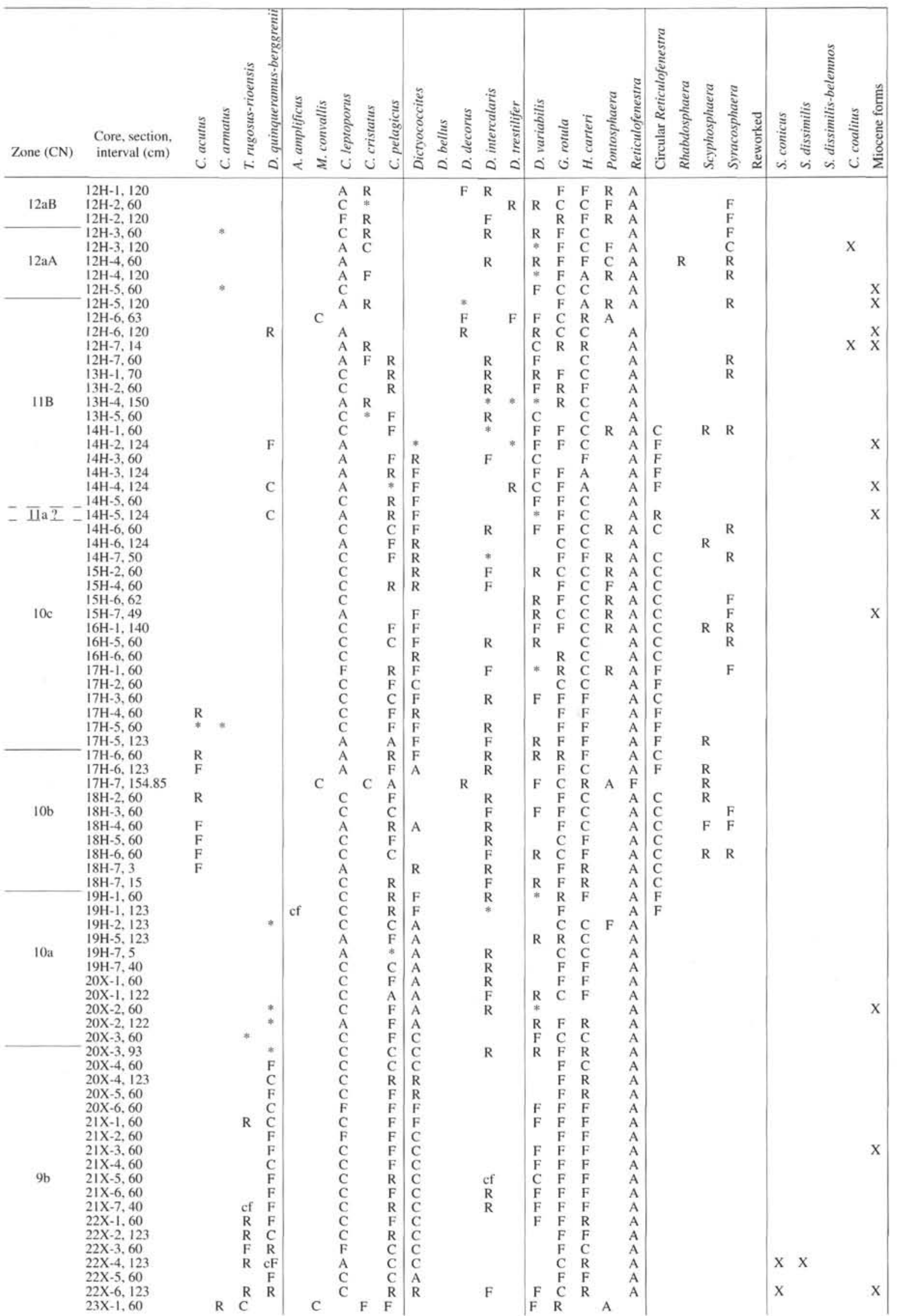


Table 16 (continued).

\begin{tabular}{|c|c|c|c|c|c|c|c|c|c|c|c|c|c|c|c|c|c|c|c|c|c|c|}
\hline Zone $(\mathrm{CN})$ & $\begin{array}{l}\text { Core, section, } \\
\text { interval }(\mathrm{cm})\end{array}$ & $\begin{array}{l}\text { Depth } \\
\text { (mbsf) }\end{array}$ & $\begin{array}{l}\text { Depth } \\
\text { (mcd) }\end{array}$ & Abundance & Preservation & Etching & Overgrowth & 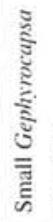 & $\begin{array}{l} \\
\vdots \\
\vdots \\
\vdots \\
\vdots\end{array}$ & 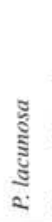 & : & $\begin{array}{c}\vdots \\
\vdots \\
\vdots \\
\vdots \\
\vdots \\
\vdots \\
0 \\
0\end{array}$ & 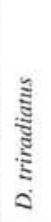 & 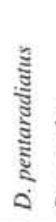 & 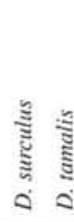 & 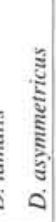 & 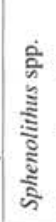 & 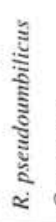 & 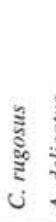 & 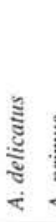 & 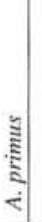 & 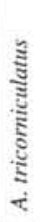 \\
\hline $9 b$ & $\begin{array}{l}23 X-4,123 \\
23 X-7,40 \\
24 X-1,122 \\
24 X-4,122 \\
24 X-7,40 \\
25 X-3,60 \\
25 X-4,60 \\
25 X-5,60 \\
25 X-6,60 \\
25 X-7,40 \\
26 X-C C \\
27 X-C C\end{array}$ & $\begin{array}{l}207.03 \\
210.7 \\
213.72 \\
218.22 \\
221.9 \\
225.8 \\
227.3 \\
228.8 \\
230.3 \\
231.6 \\
232.04 \\
241.54\end{array}$ & $\begin{array}{l}226.38 \\
230.05 \\
233.07 \\
237.57 \\
241.25 \\
245.15 \\
246.65 \\
248.15 \\
249.65 \\
250.95 \\
251.39 \\
260.89\end{array}$ & $\begin{array}{l}\mathrm{A} \\
\mathrm{A} \\
\mathrm{A} \\
\mathrm{A} \\
\mathrm{A} \\
\mathrm{A} \\
\mathrm{A} \\
\mathrm{A} \\
\mathrm{A} \\
\mathrm{A} \\
\mathrm{R} \\
\mathrm{C}\end{array}$ & $\begin{array}{l}\text { MG } \\
M \\
M \\
M \\
M \\
M \\
M \\
M \\
M \\
M \\
P \\
M\end{array}$ & $\begin{array}{l}0 \\
1 \\
0 \\
0 \\
1 \\
1 \\
1 \\
0 \\
0 \\
0 \\
0\end{array}$ & $\begin{array}{l}2 \\
2 \\
2 \\
2 \\
2 \\
2 \\
2 \\
2 \\
2 \\
2 \\
3\end{array}$ & & & & $\begin{array}{l}\mathrm{C} \\
* \\
\mathrm{R} \\
\mathrm{R}\end{array}$ & $\begin{array}{l}\text { cf } \\
\text { cf } \\
\text { F } \\
\text { F } \\
\text { F } \\
\text { F }\end{array}$ & & * & $\begin{array}{l}\mathrm{cf} \\
\mathrm{F}\end{array}$ & & $\begin{array}{c}\mathrm{A} \\
\mathrm{A} \\
\mathrm{AA} \\
\mathrm{AA} \\
\mathrm{A} \\
\mathrm{C} \\
\mathrm{C} \\
\mathrm{A} \\
\mathrm{AA} \\
\mathrm{AA} \\
*\end{array}$ & $\begin{array}{l}\text { A } \\
\text { A } \\
\text { C } \\
\text { A } \\
\text { F } \\
\text { F } \\
\text { C } \\
\text { C } \\
\text { C } \\
\text { C }\end{array}$ & & $\begin{array}{l}\text { ct } \\
*\end{array}$ & $\begin{array}{l}\text { ef } \\
* \\
*\end{array}$ & \\
\hline
\end{tabular}

Notes: For an explanation of the abundance and preservation codes, see text. For genus names, see Appendix A. Single asterisk (*) $=$ one specimen observed

board because of the scarcity of some marker species. We could not locate some Pliocene events precisely (i.e., T A. primus and B common D. asymmetricus) or place the relative zonal boundaries. With the careful shore-based work of this study, however, we were able to substantially improve the upper Miocene biostratigraphy and recognized all the conventional and some secondary events (Fig. 9).

In the lower part of Site 850, we did not detect the lowest occurrence of $C$. coalitus; therefore, we were not able to discriminate Zone CN6 as we had at Site 849. In the assemblages of the lowermost Cores 138-850B-41X and $-42 \mathrm{X}$, we recognized the interval with common D. kugleri, which terminates at the top of Core 138-850B-41X. This finding indicates that the oldest sediments retrieved at Site 850 can be assigned to the middle part of Subzone CN5b.

\section{Site 851}

Site 851 is located beneath the highly productive surface waters along the northern edge of the South Equatorial Current, on top of crust generated at about $11-12 \mathrm{Ma}$. The upper $150 \mathrm{~m}$ of the site were triple $\mathrm{APC}$ cored, and the remainder was double $\mathrm{XCB}$ cored to basement.

The 390-mcd section spans the time interval from the Pleistocene to the middle Miocene. The sedimentary section is considered a single lithologic unit composed of foraminifer-nannofossil ooze and diatomnannofossil ooze. Aclear paleomagnetic record for the Pleistocene and part of the Pliocene (top $80 \mathrm{mcd}$ ) was obtained at this site. This record, together with the biostratigraphy, provided high-quality age control points for reconstructing sedimentation rates. The sedimentation rate pattern is typical of pelagic sedimentation in this region of the equatorial Pacific (Mayer, Pisias, Janecek, et al., 1992). There is a drop in the sedimentation at around 10 to $8 \mathrm{Ma}$. This drop is associated with an increase in dissolution. This event was observed in all the other Leg 138 sites that penetrated to this point.

We sampled Hole 851B, two cores of Hole 851C, and five cores of Hole $851 \mathrm{E}$, at a spacing that averages $40 \mathrm{~cm}$. Nannofossils are abundant and generally well preserved throughout the sequence. They provide a detailed and well-constrained biostratigraphy, as summarized in Figure 10. The nannofossil events recognized are listed in Table 10.

The abundance of discoasterids in the upper Pliocene interval is particularly low. D. tamalis and D. surculus become extinct concomitantly, and $D$. pentaradiatus is virtually absent in Zone $\mathrm{CN} 12$, whereas it is common to abundant in underlying intervals (particularly in Cores $138-851 \mathrm{~B}-8 \mathrm{H}$ to $-12 \mathrm{H}$ ).

In the upper Miocene, discoasterids are abundant and well preserved, as is the entire nannofossil assemblage. Common reworked forms from Zones CN9 and CN6 and Subzone CN5b are present in some levels of the upper Pliocene, within Subzone CN12a and Zne CN11. Poorly preserved assemblages were observed in the $\mathrm{u}_{\mathrm{i}}$ )per middle Miocene interval (within Zones CN6 and CN7), corresponding to the interval of increased dissolution and low sedimentation rates outlined above.

Close to the appearance level of C. coalitus (bottom of CN6), discoasterids are very rare and fluctuate in abundance throughout the middle Miocene interval. The presence of common to abundant $D$. kugleri in the lowermost part of the Site 851 sequence (Fig. 10) allows us to assign it to Subzone CN5b. This feature in the distribution of $D$. kugleri is correlatable between eastern transect Sites 844,845 , and 846 and western transect Sites 851 and 850 . The bottom and top of common D. kugleri, calibrated at Site 845 as occurring in the lower part of Chron 5r, provide an age constraint for the basal sediments of Site 850 and 851 , which accumulated after 11.8-11.9 Ma.

\section{Site 852}

Site 852 was drilled to provide material to study the interaction between the south Equatorial Current and the North Equatorial Countercurrent during the late Neogene. The site is located near the boundary between the two currents, north of the equator. Based on plate reconstructions, the site ever passed beneath the equatorial divergence. A continuous sedimentary record for the upper Pleistocene through the uppermost middle Miocene was recovered from four holes (852A852D) drilled at Site 852. A single lithologic unit was described, composed of a mixture of foraminifer-nannofossil ooze, with some oxide-rich beds, and radiolarian-nannofissil ooze. Because this site is located north of the high-productivity zone, the microfossil constituents differ from the more equatorial sites and the sedimentation rates are lower at Site 852. A good magnetic stratigraphy was obtained from the Pliocene to the lower upper Miocene in Holes 852B and $852 \mathrm{C}$.

In this study, we sampled Hole $852 \mathrm{~B}$ and the lowermost cores of Holes 852C and 952D at an average spacing of $40 \mathrm{~cm}$. Calcareous mannofossils are abundant and generally well or moderately well preserved throughout the entire sequence. They provide a detailed and well-constrained biostratigraphy. The nannofossil events recognized at Site 852 are reported in Table 11 and illustrated in Figure 11.

In the Pleistocene and Pliocene, nannofossils are well preserved and abundant. In this interval, we observed reworked nannofossils from the upper Miocene Zone CN9 to CN6 (NN11 to NN9). In the Pliocene and uppermost Miocene, discoasterids and ceratolithids are common or abundant. The upper Miocene discoasterid assemblage is 
Table 16 (continued).

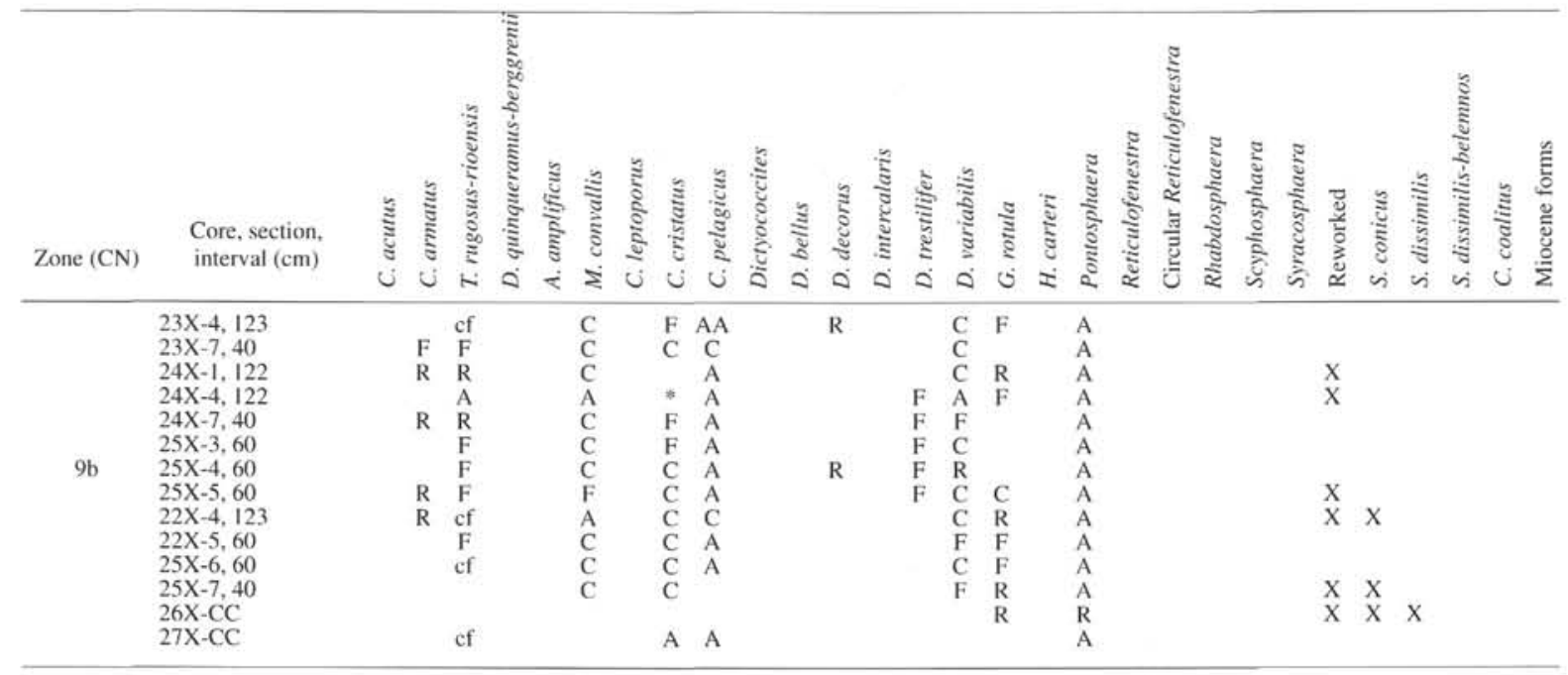

particularly rich and diverse; D. quinqueramus and D. berggreni are common throughout their stratigraphic range. Discoasterids in the upper part of middle Miocene (in Zones CN6 and CN7) show moderate overgrowth. Between 10.5 and $8.5 \mathrm{Ma}$, we observed strong dissolution of the nannofossil assemblage, and some samples were barren. This interval coincides with a time of very low sedimentation rates (as low as $3 \mathrm{~m} / \mathrm{m}$.y.) and is well correlated as a dissolution event among the Leg 138 sites that penetrated to this point in the stratigraphic record.

In samples from the lowermost part of Site 852, we recorded common specimens of Catinaster coalitus and D. calcaris and the highest occurrence of $C$. miopelagicus. These events allowed us to place this interval in Subzone CN6.

\section{Site 853}

Site 853 is presently located beneath the region dominated by the Northern Equatorial Countercurrent (NECC). The site was drilled to recover a sedimentary record suitable for studying fluctuations of the NECC and the influence of the Northern Hemisphere trade winds. A continuous section from the upper Pleistocene through the upper part of the upper Miocene was recovered from the five holes cored at Site 853. The sedimentary section is about $73 \mathrm{~m}$ thick. It is composed of clayey nannofossil oozes with levels containing abundant foraminifers and iron and manganese oxides in the upper part, and some levels of almost pure nannofossil ooze. Siliceous microfossils are virtually absent, except in the upper Pliocene and Pleistocene intervals, suggesting low-productivity conditions. Site 853 was never located beneath the equatorial divergence during its sedimentary history (Mayer, Pisias, Janecek, et al., 1992). The excellent polarity record together with the calcareous nannofossil biostratigraphy provides a well-constrained stratigraphy.

For this study, we sampled Hole 853B and the lowermost core of Hole $853 \mathrm{D}$ at an average spacing of $50 \mathrm{~cm}$. Nannofossils are generally abundant or common throughout the section, and show good to moderately good preservation. The nannofossil events recognized at Site 853 are reported in Table 12 and are summarized in Figure 12.

Within the Pliocene interval, and mainly in lower Zone CN12 and in Zone $\mathrm{CN} 11$, we observed assemblages with rare and poorly preserved nannofossils, together with common reworked forms from the upper Miocene (Zones CN9, CN7, and CN6). This observation was also made at Sites 851 and 852 . The mixture of reworked and in situ nannofossils in these Pliocene assemblages made difficult the recognition of some extinction events of long-ranging forms (like A. primus, R. pseudoumbilicus, S. abies, and S. neoabies), which are commonly present in upper Miocene assemblages.
Ceratolithids and discoasterids are generally common and abundant throughout the Pliocene and upper Miocene section, reflecting the relatively low-productivity conditions at this site, far from the equator. The lowermost part of the Site 852 sequence is placed in Zone CN8. In this interval, the nannofossil assemblage is characterized by abundant and slightly overgrown discoasterids, among which $D$. neohamatus and the $D$. bellus group dominate. Common $M$. convallis and abundant $S$. abies and $S$. neoabies are also observed.

\section{SUMMARY AND CONCLUSIONS}

We presented a chronostratigraphic classification of the calcareous nannofossil biostratigraphy of Leg 138 sediments from the Pleistocene to the late early Miocene. Most of the zonal boundaries of the standard zonations of Okada and Bukry (1980) and Martini (1971) are recognized in these eastern equatorial Pacific sediments.

The biostratigraphic classification of the Pleistocene was augmented with the biozonation proposed by Gartner (1977) and by a recent biochronologic study of low- and mid-latitude, deep-sea sequences (Raffi et al., 1993). As we used only standard light microscope techniques, we did not recognize the appearance of Emiliania huxleyi (CN15/CN14b and NN21/NN20 boundaries) or the beginning of its dominance in the upper Pleistocene interval.

Detailed biostratigraphic classification in Pliocene Zones CN12, CN11, and CN10 (Zones NN18 to NN12) was difficult at some sites because of the scattered occurrence or absence of the primary and secondary species of discoasterids and ceratolithids. At these sites, we found that discoasterids and ceratolithids were unreliable as biostratigraphic markers in much of the Pliocene and in some intervals of the middle and late Miocene because of their highly variable distributions and generally low abundances or absences, in some cases. This is particularly evident in the sedimentary sequences of sites located beneath the equatorial divergence zone and/or influenced by upwelling (in the western transect Sites 849,850 , and 851 and in the eastern transect Sites 844, 845, and 846). The rare and discontinuous occurrences of discoasterids are associated with high surface-water productivity, thus supporting the results of ChepstowLusty et al. (1989, 1992), who showed that discoasterid abundances are influenced by varying productivity pressure.

In the Miocene interval, we recognized the zonal boundaries as defined by Martini (1971) and Bukry (1973) at all sites, with some exceptions: (1) the boundary $\mathrm{CN} 7 \mathrm{a} / \mathrm{CN} 7 \mathrm{~b}$; (2) the base of Zone CN6 (NN8) at western transect Sites 849 and 850; and (3) the top of CN7 (NN9) at eastern transect Site 845. This was because of the sporadic occurrence or absence, and the different stratigraphic ranges, of the defining markers $(C$. coalitus, $C$. calyculus, and $D$. hamatus $)$. The 
Table 17. Distribution of calcareous nannofossil taxa in the Pleistocene-Pliocene interval at Site 848.

\begin{tabular}{|c|c|c|c|c|c|c|c|c|c|c|c|c|c|}
\hline $\begin{array}{l}\text { Zone } \\
(\mathrm{CN})\end{array}$ & $\begin{array}{l}\text { Core, section, } \\
\text { interval }(\mathrm{cm})\end{array}$ & $\begin{array}{l}\text { Depth } \\
\text { (mbsf) }\end{array}$ & $\begin{array}{l}\text { Depth } \\
\text { (mcd) }\end{array}$ & Abundance & Preservation & Etching & Overgrowth & P. lacunosa & $\begin{array}{c}\text { small } \\
\text { Gephyrocapsa }\end{array}$ & G. oceanica & G. omega & $\begin{array}{c}\text { large } \\
\text { Gephlyrocapsa }\end{array}$ & H. sellii \\
\hline & 138-848A- & & & & & & & & & & & & \\
\hline & $1 \mathrm{H}-1.60$ & 0.6 & 0.8 & A & G & 0 & 0 & & C & A & C & & \\
\hline $15+14 b$ & IH $-2,60$ & 2.1 & 2.3 & A & G & 0 & 0. & & C & $\mathrm{A}$ & C & & \\
\hline & $1 \mathrm{H}-3,60$ & 3.6 & 3.8 & A & G & 0 & 0 & & A & C & $\mathrm{R}$ & & \\
\hline & IH- 4,60 & 5.1 & 5.3 & A & G & 0 & 0 & & A & $\mathrm{R}$ & $\mathrm{R}$ & & \\
\hline & IH-5, 60 & 6.6 & 6.8 & A & G & 0 & 0 & F & A & $\mathrm{R}$ & $*$ & & \\
\hline & IH-6,60 & 8.1 & 8.3 & A & G & 0 & 0 & A & A & $\mathrm{R}$ & $\mathrm{R}$ & & \\
\hline & $\begin{array}{l}138-848 \mathrm{~B}- \\
2 \mathrm{H}-3,60\end{array}$ & & & & & & & & & & & & \\
\hline $14 a$ & $\begin{array}{l}2 \mathrm{H}-3,60 \\
2 \mathrm{H}-4,60\end{array}$ & $\begin{array}{l}5.8 \\
7.3\end{array}$ & $\begin{array}{r}8.6 \\
10.1\end{array}$ & $\begin{array}{l}\mathrm{A} \\
\mathrm{A}\end{array}$ & $\begin{array}{l}\mathrm{G} \\
\mathrm{G}\end{array}$ & $\begin{array}{l}0 \\
0\end{array}$ & $\begin{array}{l}0 \\
0\end{array}$ & $\begin{array}{l}\text { C } \\
\text { A }\end{array}$ & A & $\begin{array}{l}\mathrm{C} \\
\mathrm{C}\end{array}$ & $\begin{array}{l}F \\
R\end{array}$ & & \\
\hline & $2 \mathrm{H}-5,60$ & 8.8 & 11.6 & $\hat{A}$ & G & 0 & $\begin{array}{l}0 \\
0\end{array}$ & C & A & C & $\begin{array}{l}\mathrm{K} \\
\mathrm{R}\end{array}$ & & \\
\hline & $2 \mathrm{H}-6,60$ & 10.1 & 12.9 & A & G & 0 & 0 & C & C & $\mathrm{F}$ & $\ddot{R}$ & & \\
\hline & $2 \mathrm{H}-7,70$ & 11.9 & 14.7 & A & G & 0 & 0 & A & C & A & C & & \\
\hline & $3 \mathrm{H}-\mathrm{I}, 60$ & 12.3 & 16.25 & A & G & 0 & 0 & A & C & $\mathrm{F}$ & $\mathrm{R}$ & & \\
\hline & $3 \mathrm{H}-1,70$ & 12.4 & 16.35 & A & G & 0 & 0 & A & $\mathrm{F}$ & $\mathrm{R}$ & R & & \\
\hline & $3 \mathrm{H}-1,80$ & 12.5 & 16.45 & A & G & 0 & 0 & A & C & & & & \\
\hline & $3 \mathrm{H}-\mathrm{I}, 120$ & 12.9 & 16.85 & A & G & 0 & 0 & A & F & & & & \\
\hline & $3 \mathrm{H}-2,60$ & 13.8 & 17.75 & A & G & 0 & 0 & A & C & & & & \\
\hline & $3 \mathrm{H}-3,60$ & 15.3 & 19.25 & A & G & 0 & 0 & A & $\mathrm{F}$ & & & & \\
\hline & $3 \mathrm{H}-3,120$ & 15.9 & 19.85 & A & G & 0 & 0 & A & $\mathrm{F}$ & F & & F & \\
\hline & $3 \mathrm{H}-4,40$ & 16.6 & 20.55 & A & G & 0 & 0 & A & C & A & & C & \\
\hline $13 \mathrm{~b}$ & $3 \mathrm{H}-4,80$ & 17 & 20.95 & A & G & 0 & 0 & A & C & $\ddot{A}$ & & $\mathrm{~F}$ & \\
\hline & $3 \mathrm{H}-4,120$ & 17.4 & 21.35 & A & G & 0 & 0 & A & C & C & & $\mathrm{R}$ & \\
\hline & $3 \mathrm{H}-5,40$ & 18.1 & 22.05 & A & G & 0 & 0 & A & C & A & & F & \\
\hline & $3 \mathrm{H}-5,80$ & 18.5 & 22.45 & A & G & 0 & 0 & C & A & A & & F & \\
\hline & $3 \mathrm{H}-5,120$ & 18.9 & 22.85 & $\hat{A}$ & G & 0 & 0 & $\mathrm{~F}$ & C & $\mathrm{c}$ & & R & $*$ \\
\hline & $3 \mathrm{H}-6,40$ & 19.6 & 23.55 & A & G & 0 & 0 & A & C & A & & & \\
\hline & $3 \mathrm{H}-6.80$ & 20 & 23.95 & A & G & 0 & 0 & C & C & A & & & \\
\hline & $144-848 \mathrm{C}$ - & & & & & & & & & & & & \\
\hline & $3 \mathrm{H}-5,20$ & 21.2 & 24.2 & A & G & 0 & 0 & C & F & $\mathrm{F}$ & & & $\mathrm{R}$ \\
\hline$\ldots$ & $3 \mathrm{H}-5,40$ & 21.4 & 24.4 & A & G & 0 & 0 & A & $R$ & C & & & $\mathrm{R}$ \\
\hline & $3 \mathrm{H}-5,50$ & 21.5 & 24.5 & A & G & 0 & 0 & A & $\mathrm{F}$ & & & & \\
\hline & $3 \mathrm{H}-5,60$ & 21.6 & 24.6 & A & G & 0 & 0 & A & F & & & & C \\
\hline & $3 \mathrm{H}-5,90$ & 21.9 & 24.9 & $\hat{A}$ & G & 0 & 0 & A & C & & & & $\mathrm{A}^{*}$ \\
\hline & $3 \mathrm{H}-5,100$ & 22 & 25 & $\hat{A}$ & MG & i & 0 & A & C & & & & $\mathrm{A}^{*}$ \\
\hline $13 \mathrm{a}$ & $3 \mathrm{H}-5,120$ & 22.2 & 25.2 & A & $\mathrm{G}$ & 0 & 0 & A & C & & & & A \\
\hline & $3 \mathrm{H}-5,140$ & 22.4 & 25.4 & A & G & 0 & 0 & A & C & & & & c \\
\hline & $3 \mathrm{H}-6,20$ & 22.7 & 25.7 & A & MG & 1 & 0 & A & $\mathrm{F}$ & & & & C \\
\hline & $3 \mathrm{H}-6.50$ & 23 & 26 & $\hat{A}$ & $\mathrm{G}$ & 0 & 0 & A & $\mathrm{F}$ & & & & $\mathrm{A}^{*}$ \\
\hline & $3 \mathrm{H}-6.80$ & 23.3 & 26.3 & $\ddot{A}$ & MG & i & 0 & A & $\mathrm{F}$ & & & & C \\
\hline & $3 \mathrm{H}-6,120$ & 23.7 & 26.7 & A & G & 0 & 0 & A & $\mathrm{F}$ & & & & A \\
\hline & $3 \mathrm{H}-7,10$ & 24.1 & 27.1 & A & G & 0 & 0 & A & F & & & & C \\
\hline & $3 \mathrm{H}-7,20$ & 24.2 & 27.2 & A & G & 0 & 0 & A & $\mathrm{F}$ & & & & C \\
\hline & $3 \mathrm{H}-7,30$ & 24.3 & 27.3 & A & G & 0 & 0 & A & $\mathrm{F}$ & & & & C \\
\hline & $3 \mathrm{H}-7,40$ & 24.4 & 27.4 & A & G & 0 & 0 & A & $\mathrm{R}$ & & & & C \\
\hline $12 \mathrm{~d}$ & $3 \mathrm{H}-7,50$ & 24.5 & 27.5 & A & G & 0 & 0 & A & & & & & C \\
\hline+ & $3 \mathrm{H}-7,60$ & 24.6 & 27.6 & A & G & 0 & 0 & A & & & & & F \\
\hline $12 \mathrm{c}$ & $4 \mathrm{H}-3,40$ & 24.6 & 28.95 & A & G & 0 & 0 & A & & & & & F \\
\hline & $4 \mathrm{H}-3,120$ & 25.4 & 29.75 & A & G & 0 & 0 & A & & & & & $\mathrm{R}$ \\
\hline & $4 \mathrm{H}-4,40$ & 26.1 & 30.45 & A & G & 0 & 0 & A & & & & & $\mathrm{R}$ \\
\hline & $4 \mathrm{H}-4,80$ & 26.5 & 30.85 & A & MG & 0 & 0 & A & & & & & R \\
\hline $12 \mathrm{~b}$ & $4 \mathrm{H}-4,120$ & 26.9 & 31.25 & A & G & 0 & 0 & A & & & & & $\mathrm{R}$ \\
\hline & $4 \mathrm{H}-5,23$ & 27.43 & 31.78 & A & G & 0 & 0 & A & & & & & $\mathrm{R}$ \\
\hline & $4 \mathrm{H}-5,85$ & 28.05 & 32.4 & A & G & 0 & 0 & $\ddot{A}$ & & & & & C \\
\hline & $4 \mathrm{H}-5,120$ & 28.4 & 32.75 & A & G & 0 & 0 & C & & & & & R \\
\hline & $4 \mathrm{H}-6,20$ & 28.9 & 33.25 & A & G & 0 & 0 & C & & & & & R \\
\hline $12 \mathrm{aB}$ & $4 \mathrm{H}-6,120$ & 29.9 & 34.25 & A & G & 0 & 0 & C & & & & & $\mathrm{R}$ \\
\hline 2aD & $4 \mathrm{H}-6.145$ & 30.15 & 34.5 & $\hat{A}$ & G & 0 & 0 & $\mathrm{C}$ & & & & & \\
\hline & $4 \mathrm{H}-7,20$ & 30.4 & 34.75 & A & G & 0 & 0 & C & & & & & $\mathrm{R}$ \\
\hline & $4 \mathrm{H}-7.50$ & 30.7 & 35.05 & $\hat{A}$ & MG & 0 & 0 & $\mathrm{~F}$ & & & & & $\mathrm{~F}$ \\
\hline $12 \mathrm{aA}$ & $5 \mathrm{H}-1,42$ & 31.12 & 36.77 & A & G & 0 & 0 & $\mathrm{R}$ & & & & & C \\
\hline & $5 \mathrm{H}-1,95$ & 31.65 & 37.3 & A & MG & 1 & 0 & $\ddot{R}$ & & & & & $\mathrm{R}$ \\
\hline $1 \mathrm{Ib}$ & $5 \mathrm{H}-\mathrm{I}, 120$ & 31.9 & 37.55 & A & MG & i & 0 & & & & & & F \\
\hline$-2=$ & $5 \mathrm{H}-2.50$ & 32.7 & 38.35 & A & MG & i & 0 & & & & & & \\
\hline$?=-$ & $5 \mathrm{H}-2.120$ & 33.4 & 39.05 & A & G & 0 & 0 & & & & & & $R$ \\
\hline $11 \mathrm{a}$ & $5 \mathrm{H}-2,127$ & 33.47 & 39.12 & A & G & 0 & 0 & & & & & & \\
\hline & $5 \mathrm{H}-3.62$ & 34.32 & 39.97 & A & G & 0 & 0 & & & & & & \\
\hline & $5 \mathrm{H}-3,120$ & 34.9 & 40.55 & A & G & 0 & 0 & & & & & & \\
\hline & $5 \mathrm{H}-4,40$ & 35.6 & 41.25 & A & G & 0 & 0 & & & & & & \\
\hline & $5 \mathrm{H}-4,120$ & 36.4 & 42.05 & A & MG & 0 & 1 & & & & & & \\
\hline & $5 \mathrm{H}-5,40$ & 37.1 & 42.75 & A & MG & 1 & 0 & & & & & & \\
\hline & $5 \mathrm{H}-5,120$ & 37.9 & 43.55 & c & MG & $i$ & i & & & & & & \\
\hline $10 c$ & $5 \mathrm{H}-6.40$ & 38.6 & 44.25 & A & G & 0 & 0 & & & & & & \\
\hline & $5 \mathrm{H}-6,120$ & 39.4 & 45.05 & A & MG & 0 & i & & & & & & \\
\hline & $5 \mathrm{H}-7.45$ & 40.15 & 45.8 & A & G & 0 & 0 & & & & & & \\
\hline & $6 \mathrm{H}-1,75$ & 40.95 & 46.65 & A & G & 0 & 0 & & & & & & \\
\hline & $6 \mathrm{H}-2,35$ & 42.05 & 47.75 & $\hat{A}$ & $\mathrm{G}$ & 0 & 0 & & & & & & \\
\hline & $6 \mathrm{H}-2,75$ & 42.45 & 48.15 & A & MG & 0 & I & & & & & & \\
\hline & $6 \mathrm{H}-3,35$ & 43.55 & 49.25 & A & G & 0 & $\mathrm{i}$ & & & & & & \\
\hline & $6 \mathrm{H}-3,75$ & 43.95 & 49.65 & A & MG & 1 & 1 & & & & & & \\
\hline & $6 \mathrm{H}-4,35$ & 45.05 & 50.75 & A & MG & i & i & & & & & & \\
\hline $10 \mathrm{~b}$ & $6 \mathrm{H}-4.75$ & 45.45 & 51.15 & A & G & 0 & i & & & & & & \\
\hline & $6 \mathrm{H}-5,35$ & 46.55 & 52.25 & A & MG & 0 & i & & & & & & \\
\hline $10 a$ & $6 \mathrm{H}-5,75$ & 46.95 & 52.65 & A & MG & 0 & i & & & & & & \\
\hline
\end{tabular}


Table 17 (continued). 
I. RAFFI, J.-A. FLORES

Table 17 (continued).

\begin{tabular}{|c|c|c|c|c|c|c|c|c|c|c|c|}
\hline $\begin{array}{l}\text { Zone } \\
\text { (CN) }\end{array}$ & $\begin{array}{l}\text { Core, section, } \\
\text { interval }(\mathrm{cm})\end{array}$ & C. acutus & T. rugosus/rioensis & D. quinqueramus & C. leptoporus & C. cristatus/telesmus & C. pelagicus & C. radiatus & D. decorus & D. intercalaris & D. pansus \\
\hline \multirow{6}{*}{$15+14 b$} & 138-848A- & & & & & & & $C$ & & & \\
\hline & $\begin{array}{l}\mathrm{IH}-1,60 \\
\mathrm{IH}-2,60\end{array}$ & & & & $\begin{array}{l}\mathrm{C} \\
\mathrm{C}\end{array}$ & $\begin{array}{l}F \\
R\end{array}$ & & $\mathrm{~F}$ & & & \\
\hline & IH-3, 60 & & & & C & R & & $\mathrm{F}$ & & & \\
\hline & $\mathrm{IH}-4,60$ & & & & $\mathrm{C}$ & $\mathrm{F}$ & & $\mathrm{R}$ & & & \\
\hline & $\mathrm{IH}-5,60$ & & & & C & $\mathrm{R}$ & & $\mathrm{R}$ & & & \\
\hline & IH-6, 60 & & & $\mathrm{C}$ & $\mathrm{F}$ & & C & & & & \\
\hline & I38-848B- & & & & & & & & & & \\
\hline & $2 \mathrm{H}-3,60$ & & & & $\mathrm{C}$ & $\mathrm{R}$ & & $\mathrm{C}$ & & & \\
\hline $14 a$ & $2 \mathrm{H}-4,60$ & & & & C & $\mathrm{R}$ & & C & & & \\
\hline & $2 \mathrm{H}-5,60$ & & & & $\mathrm{C}$ & $\ddot{R}$ & & $\mathrm{R}$ & & & \\
\hline & $2 \mathrm{H}-6,60$ & & & & A & $\mathrm{F}$ & & $\mathrm{F}$ & & & \\
\hline & $2 \mathrm{H}-7,70$ & & & & $\mathrm{C}$ & $\mathrm{R}$ & & & & & \\
\hline & $3 \mathrm{H}-1.60$ & & & & A & & & $\mathrm{R}$ & & & \\
\hline$\ldots$ & $3 \mathrm{H}-1,70$ & & & & A & $\mathrm{R}$ & & $\mathrm{F}$ & & & \\
\hline$----1-$ & $3 \mathrm{H}-\mathrm{I}, 80$ & & & & A & $\mathrm{R}$ & & $\mathrm{F}$ & & & \\
\hline & $3 \mathrm{H}-1,120$ & & & & $\mathrm{~A}$ & & & $\mathrm{R}$ & & & \\
\hline & $3 \mathrm{H}-2,60$ & & & & A & & & $\mathrm{F}$ & & & \\
\hline & $3 \mathrm{H}-3,60$ & & & & A & $\mathrm{F}$ & & & & & \\
\hline & $3 \mathrm{H}-3,120$ & & & & A & $\dot{R}$ & & $\mathrm{~F}$ & & & \\
\hline & $3 \mathrm{H}-4,40$ & & & & A & F & & C & & & \\
\hline $13 \mathrm{~b}$ & $3 \mathrm{H}-4,80$ & & & & A & C & & $\mathrm{F}$ & & & \\
\hline & $3 \mathrm{H}-4,120$ & & & $*$ & A & $\mathrm{R}$ & & $\mathrm{R}$ & & & \\
\hline & $3 \mathrm{H}-5,40$ & & & & $\mathrm{~A}$ & $\mathrm{~F}$ & & $\mathrm{C}$ & & & \\
\hline & $3 \mathrm{H}-5,80$ & & & & $\mathrm{~A}$ & $\mathrm{R}$ & & $\mathrm{C}$ & & & \\
\hline & $3 \mathrm{H}-5,120$ & & & & A & R & & $\mathrm{F}$ & & & \\
\hline & $3 \mathrm{H}-6,40$ & & & & $\mathrm{C}$ & $\mathrm{F}$ & & C & & & \\
\hline & $3 \mathrm{H}-6,80$ & & & & A & $\mathrm{F}$ & & $\mathrm{F}$ & & & \\
\hline & $144-848 \mathrm{C}$ - & & & & & & & & & & \\
\hline & $3 \mathrm{H}-5,20$ & & & & $\mathrm{C}$ & $\mathrm{F}$ & & $\mathrm{F}$ & & * & \\
\hline & $3 \mathrm{H}-5,40$ & & & & C & $\mathrm{F}$ & & C & & & \\
\hline & $3 \mathrm{H}-5,50$ & & & & C & $\mathrm{F}$ & & $\mathrm{F}$ & & & \\
\hline & $3 \mathrm{H}-5,60$ & & & & C & $\mathrm{R}$ & & C & & & \\
\hline & $3 \mathrm{H}-5,90$ & & & & A & A & & $\mathrm{F}$ & & & \\
\hline & $3 \mathrm{H}-5,100$ & & & & C & $\mathrm{F}$ & & $\mathrm{F}$ & & & \\
\hline $13 \mathrm{a}$ & $3 \mathrm{H}-5,120$ & & & & A & C & $\mathrm{R}$ & C & & & \\
\hline & $3 \mathrm{H}-5,140$ & & & & $\hat{A}$ & $\mathrm{C}$ & & $\mathrm{C}$ & & & \\
\hline & $3 \mathrm{H}-6,20$ & & & & A & C & & C & & & \\
\hline & $3 \mathrm{H}-6,50$ & & & & C & C & & $\mathrm{F}$ & & & \\
\hline & $3 \mathrm{H}-6,80$ & & & & $\mathrm{C}$ & A & & $\mathrm{C}$ & & & \\
\hline & $3 \mathrm{H}-6,120$ & & & & A & $\mathrm{C}$ & & $\mathrm{C}$ & & & \\
\hline & $3 \mathrm{H}-7,10$ & & & & A & $\mathrm{F}$ & & C & & & \\
\hline & $3 \mathrm{H}-7,20$ & & & & A & C & & C & & & \\
\hline & $3 \mathrm{H}-7,30$ & & & & A & $\mathrm{C}$ & & $\mathrm{F}$ & & & \\
\hline & $3 \mathrm{H}-7,40$ & & & & A & A & $\mathrm{R}$ & $\mathrm{F}$ & & & \\
\hline $12 \mathrm{~d}$ & $3 \mathrm{H}-7,50$ & & & & A & C & $\mathrm{F}$ & C & & & \\
\hline+ & $3 \mathrm{H}-7,60$ & & & & A & C & $\mathrm{F}$ & $\mathrm{C}$ & & & \\
\hline $12 \mathrm{c}$ & $4 \mathrm{H}-3,40$ & & & & A & A & C & $\mathrm{F}$ & & & \\
\hline & $4 \mathrm{H}-3,120$ & & & & $\mathrm{~A}$ & $\mathrm{~F}$ & $\mathrm{C}$ & $\mathrm{R}$ & & & \\
\hline & $-4 \mathrm{H}-4,40$ & & & & A & $\mathrm{F}$ & C & $\ddot{R}$ & & * & \\
\hline & $4 \mathrm{H}-4,80$ & & & & A & C & $\mathrm{F}$ & $\mathrm{R}$ & & * & \\
\hline $12 b$ & $4 \mathrm{H}-4,120$ & & & & A & C & $\mathrm{F}$ & $\mathrm{F}$ & & & \\
\hline & $4 \mathrm{H}-5,23$ & & & & A & A & $\mathrm{F}$ & $\mathrm{F}$ & & & \\
\hline & $4 \mathrm{H}-5,85$ & & & & $\mathrm{~A}$ & A & C & $\mathrm{F}$ & & & \\
\hline & $4 \mathrm{H}-5,120$ & & & & A & $\mathrm{C}$ & $\mathrm{F}$ & C & & & \\
\hline & $4 \mathrm{H}-6,20$ & & & & A & $\mathrm{F}$ & $\mathrm{F}$ & $\mathrm{F}$ & & $\mathrm{R}$ & \\
\hline $12 \mathrm{aB}$ & $4 \mathrm{H}-6,120$ & & & & A & $\mathrm{F}$ & A & $\mathrm{F}$ & & & \\
\hline & $4 \mathrm{H}-6,145$ & & & & A & C & $\mathrm{R}$ & $\mathrm{F}$ & & $\mathrm{R}$ & \\
\hline & $4 \mathrm{H}-7,20$ & & & & A & $\mathrm{C}$ & $\mathrm{R}$ & $\mathrm{R}$ & & $\mathrm{R}$ & \\
\hline & $4 \mathrm{H}-7,50$ & & & & A & C & & $\mathrm{C}$ & * & $\mathrm{F}$ & \\
\hline $12 \mathrm{aA}$ & $5 \mathrm{H}-1,42$ & & & & A & A & & $\mathrm{R}$ & & & \\
\hline & $5 \mathrm{H}-1,95$ & & & & A & C & & $\mathrm{F}$ & & & \\
\hline $11 \mathrm{~b}$ & $5 \mathrm{H}-\mathrm{I}, 120$ & & & & A & $\mathrm{F}$ & & $\mathrm{R}$ & & & \\
\hline$--?-?--$ & $5 \mathrm{H}-2,50$ & & & & A & C & & $\mathrm{F}$ & & & \\
\hline & $5 \mathrm{H}-2,120$ & & & A & C & & $\mathrm{R}$ & & & $*$ & \\
\hline $11 \mathrm{a}$ & $5 \mathrm{H}-2,127$ & & & & A & $\mathrm{F}$ & & $\mathrm{F}$ & & $\mathrm{R}$ & \\
\hline & $5 \mathrm{H}-3,62$ & & & & A & $\mathrm{R}$ & & C & & $\mathrm{R}$ & * \\
\hline & $5 \mathrm{H}-3,120$ & & & & A & $\mathrm{R}$ & & $\mathrm{F}$ & & & \\
\hline & $5 \mathrm{H}-4,40$ & & & & A & $\mathrm{F}$ & & $\mathrm{F}$ & & & \\
\hline & $5 \mathrm{H}-4,120$ & & & & A & & & $\mathrm{R}$ & & $\mathbf{R}$ & \\
\hline & $5 \mathrm{H}-5,40$ & & & & A & & & $\mathrm{R}$ & & $\mathrm{R}$ & \\
\hline & $5 \mathrm{H}-5,120$ & & & & C & & & & & & \\
\hline $10 \mathrm{c}$ & $5 \mathrm{H}-6,40$ & & & & A & & & & & & \\
\hline & $5 \mathrm{H}-6,120$ & & & & A & & & & & & \\
\hline & $5 \mathrm{H}-7,45$ & & & & C & & & & & & \\
\hline & $6 \mathrm{H}-1,75$ & & & & A & & C & & & & \\
\hline & $6 \mathrm{H}-2,35$ & $\mathrm{R}$ & & & A & & C & & & $\mathrm{F}$ & \\
\hline & $6 \mathrm{H}-2,75$ & $\mathrm{R}$ & & & A & & $\mathrm{F}$ & & & $\mathrm{F}$ & \\
\hline & $6 \mathrm{H}-3,35$ & $\mathrm{R}$ & & & A & & $\mathrm{R}$ & & & F & \\
\hline & $6 \mathrm{H}-3,75$ & $\mathrm{R}$ & & & A & & C & R & & & \\
\hline & $6 \mathrm{H}-4,35$ & C & & & $\mathrm{A}$ & & $\mathrm{C}$ & & & & \\
\hline $10 \mathrm{~b}$ & $6 \mathrm{H}-4,75$ & $\mathrm{~F}$ & & & A & & $\mathrm{F}$ & & & & \\
\hline & $6 \mathrm{H}-5,35$ & C & * & & A & & $\mathbf{R}$ & & & & \\
\hline $10 \mathrm{a}$ & $6 \mathrm{H}-5,75$ & * & $\mathrm{F}$ & & A & & $\mathrm{F}$ & & & & \\
\hline
\end{tabular}


Table 17 (continued).

D. tristellifer D. variabilis G. rotula H. carteri gr. H. wallichii Pontosphaera Reticulofenestra Rhabdosphaera Syracosphaera Thoracosphaera Umbilicosphaera Reworked

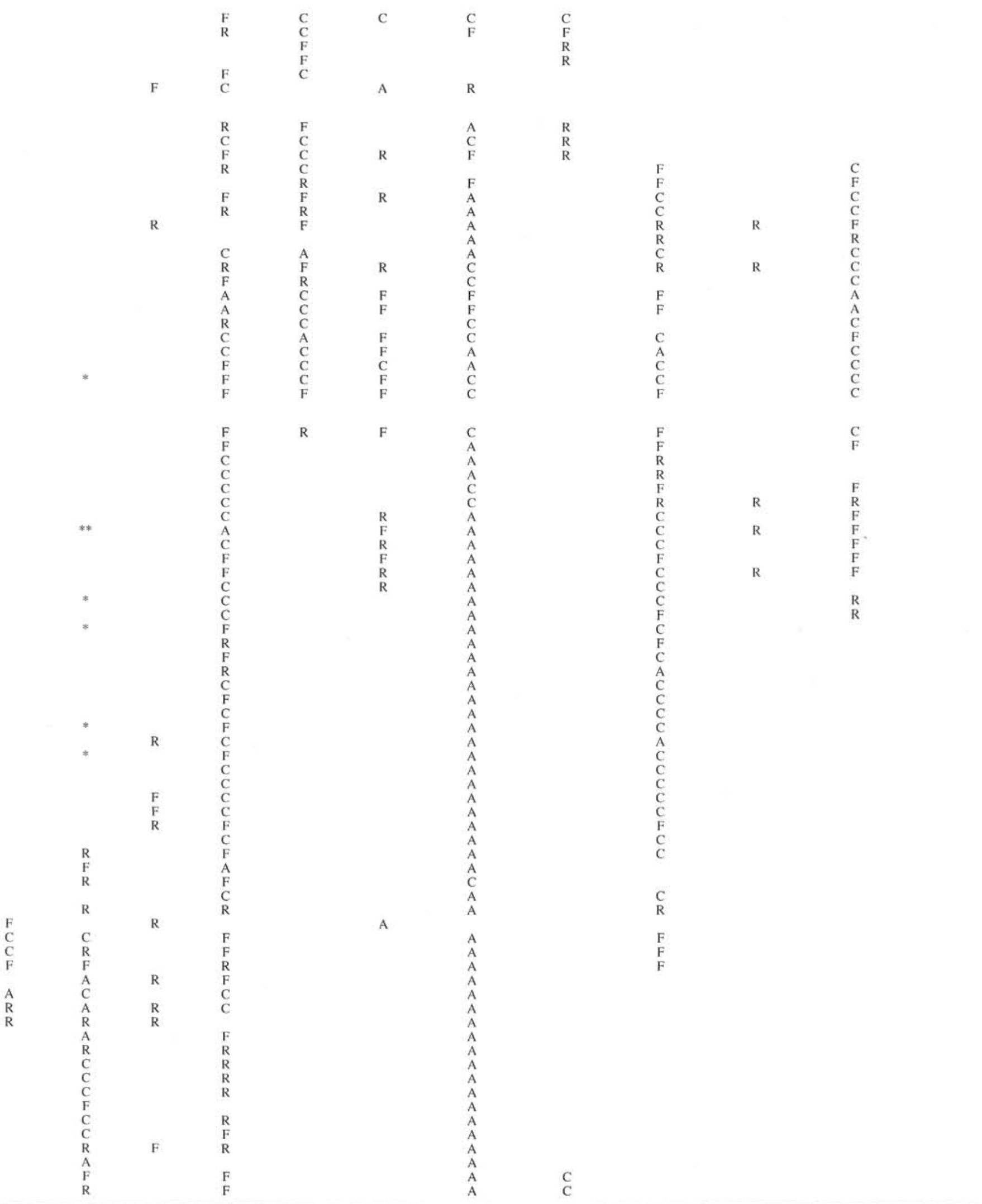

Notes: For an explanation of the abundance and preservation codes, see text. For genus names, see Appendix A. Single asterisk $(*)=$ one specimen observed. A* $=$ dominant species $(50 \%)$ 
Table 18. Distribution of calcareous nannofossil taxa in the Miocene interval at Site 848.

\begin{tabular}{|c|c|c|c|c|c|c|c|c|c|c|c|c|}
\hline $\begin{array}{l}\text { Zone } \\
(\mathrm{CN})\end{array}$ & $\begin{array}{l}\text { Core, section, } \\
\text { interval }(\mathrm{cm})\end{array}$ & $\begin{array}{l}\text { Depth } \\
\text { (mbsf) }\end{array}$ & $\begin{array}{l}\text { Depth } \\
\text { (mcd) }\end{array}$ & Abundance & Preservation & Etching & Overgrowth & C. macintyrei & D. brouweri & D. triradiatus & D. pentaradiatus & D. surculus \\
\hline & 138-848B- & & & & & & & & & & & \\
\hline \multirow{7}{*}{$10 \mathrm{a}$} & $6 \mathrm{H}-6.35$ & 48.05 & 53.75 & A & MG & 0 & 1 & $R$ & A & & $\mathrm{F}$ & C \\
\hline & $6 \mathrm{H}-6.75$ & 48.45 & 54.15 & A & $\mathrm{G}$ & 0 & 0 & $R$ & $\mathrm{~F}$ & & $R$ & $\stackrel{\mathrm{C}}{\mathrm{C}}$ \\
\hline & $\begin{array}{l}6 \mathrm{H}-7,40 \\
7 \mathrm{H}-\mathrm{I}, 50\end{array}$ & $\begin{array}{l}49.6 \\
50.2\end{array}$ & $\begin{array}{l}55.3 \\
56.9\end{array}$ & $\begin{array}{l}\mathrm{A} \\
\mathrm{A}\end{array}$ & $\begin{array}{l}\text { MG } \\
\text { MG }\end{array}$ & $\begin{array}{l}0 \\
0\end{array}$ & $\begin{array}{l}1 \\
2\end{array}$ & $\mathrm{R}$ & $\begin{array}{l}\mathrm{C} \\
\mathrm{C}\end{array}$ & & R & C \\
\hline & $7 \mathrm{H}-1.95$ & 50.65 & 57.35 & A & MG & 0 & $i$ & $\mathrm{R}$ & $\mathrm{F}$ & & & A \\
\hline & $7 \mathrm{H}-2,35$ & 51.55 & 58.25 & A & MG & 0 & 2 & & C & & & A \\
\hline & $7 \mathrm{H}-2,120$ & 52.4 & 59.1 & A & G & 0 & 1 & R & $\mathrm{R}$ & & & C \\
\hline & $7 \mathrm{H}-3,35$ & 53.05 & 59.75 & A & MG & 0 & 2 & * & $\mathrm{F}$ & * & $\mathrm{R}$ & A \\
\hline \multirow[t]{8}{*}{$9 b C$} & $7 \mathrm{H}-3,120$ & 53.9 & 60.6 & A & MG & 0 & 2 & & $\mathrm{~F}$ & & & C \\
\hline & 138-848C- & & & & MG & & & & & & & \\
\hline & $\begin{array}{l}7 \mathrm{H}-1,25 \\
7 \mathrm{H}-1,100\end{array}$ & $\begin{array}{l}53.25 \\
54\end{array}$ & $\begin{array}{l}61 \\
61.75\end{array}$ & $\stackrel{A}{A}$ & $\begin{array}{l}\mathrm{MG} \\
\mathrm{MG}\end{array}$ & $\begin{array}{l}0 \\
0\end{array}$ & $\frac{2}{2}$ & ${ }_{\mathrm{R}}^{\mathrm{R}}$ & $\stackrel{\mathrm{F}}{\mathrm{C}}$ & & $F$ & $\begin{array}{l}\mathrm{F} \\
\mathrm{R}\end{array}$ \\
\hline & $7 \mathrm{H}-2,25$ & 54.75 & 62.5 & $\hat{A}$ & MG & 0 & 2 & K & C & & . & $\begin{array}{l}\mathrm{K} \\
\mathrm{R}\end{array}$ \\
\hline & $7 \mathrm{H}-2,50$ & 55 & 62.75 & $\ddot{A}$ & MG & 0 & 2 & & C & & & R \\
\hline & $7 \mathrm{H}-3,50$ & 56.5 & 64.25 & $\hat{A}$ & $\mathrm{M}$ & 1 & 2 & $\mathrm{R}$ & $\mathrm{C}$ & * & & $\mathrm{R}$ \\
\hline & $7 \mathrm{H}-3,100$ & 57 & 64.75 & A & $\mathrm{M}$ & i & 2 & * & $\mathrm{C}$ & & & $\mathrm{R}$ \\
\hline & $7 \mathrm{H}-4.25$ & 57.75 & 65.5 & A & M & 1 & 2 & F & A & & & $\mathrm{R}$ \\
\hline \multirow[t]{12}{*}{ 9bB } & $7 \mathrm{H}-4,100$ & 58.5 & 66.25 & A & MG & 0 & i & F & $A^{*}$ & & & R \\
\hline & $7 \mathrm{H}-5,25$ & 59.25 & 67 & A & MG & 0 & i & F & $\mathrm{A}^{*}$ & ** & & \\
\hline & $7 \mathrm{H}-5,100$ & 60 & 67.75 & A & MG & 0 & i & F & A & & & \\
\hline & $7 \mathrm{H}-6,25$ & 60.75 & 68.5 & A & MG & 0 & $i$ & F & $\mathrm{A}^{*}$ & & & * \\
\hline & $7 \mathrm{H}-6,100$ & 61.5 & 69.25 & A & G & 0 & i & $\mathbf{R}$ & $\mathrm{F}$ & & & $\mathrm{R}$ \\
\hline & $7 \mathrm{H}-6,125$ & 61.75 & 69.5 & A & MG & 0 & i & $\mathrm{F}$ & $\mathrm{F}$ & & & * \\
\hline & $7 \mathrm{H}-6,145$ & 61.95 & 69.7 & A & MG & 0 & i & F & C & & & $\mathrm{R}$ \\
\hline & $7 \mathrm{H}-7,20$ & 62.2 & 69.95 & A & MG & 0 & 2 & $\mathrm{~F}$ & C & & & $\mathrm{R}$ \\
\hline & $7 \mathrm{H}-7.50$ & 62.5 & 70.25 & A & M & 1 & 2 & $\mathrm{~F}$ & C & & & $\mathrm{R}$ \\
\hline & $8 \mathrm{H}-1,80$ & 63.3 & 72.4 & A & M & 1 & 2 & F & A & & & $\mathrm{F}$ \\
\hline & $8 \mathrm{H}-1,140$ & 63.9 & 73 & A & M & 1 & 2 & $\mathrm{~F}$ & A & & & $\mathrm{F}$ \\
\hline & $8 \mathrm{H}-2,80$ & 64.8 & 73.9 & A & $\mathrm{M}$ & i & 2 & $\mathrm{~F}$ & A & & & F \\
\hline \multirow{12}{*}{$9 \mathrm{bA}$} & $8 \mathrm{H}-2,140$ & 65.4 & 74.5 & A & $\mathrm{M}$ & i & 2 & $\mathrm{~F}$ & C & & & $\mathrm{R}$ \\
\hline & $8 \mathrm{H}-3,40$ & 65.9 & 75 & A & M & i & 2 & $\mathrm{~F}$ & C & & & \\
\hline & $8 \mathrm{H}-3,100$ & 66.5 & 75.6 & A & M & i & 2 & C & C & & & $\mathrm{F}$ \\
\hline & $8 \mathrm{H}-4,20$ & 67.2 & 76.3 & A & M & 1 & 2 & $\mathrm{~F}$ & $\mathrm{C}$ & & * & $\mathrm{R}$ \\
\hline & $8 \mathrm{H}-4,100$ & 68 & 77.1 & A & M & i & 2 & C & C & & & C \\
\hline & $8 \mathrm{H}-5,20$ & 68.7 & 77.8 & A & M & i & 2 & $\mathrm{R}$ & A & * & & * \\
\hline & $8 \mathrm{H}-5,140$ & 69.9 & 79 & A & $\mathrm{M}$ & i & 2 & $\hat{F}$ & C & & & F \\
\hline & $8 \mathrm{H}-6,80$ & 70.8 & 79.9 & A & M & i & 2 & $\mathrm{R}$ & A & & & F \\
\hline & $8 \mathrm{H}-6,140$ & 71.4 & 80.5 & $\hat{A}$ & M & i & 2 & $\ddot{R}$ & C & & & * \\
\hline & $8 \mathrm{H}-7,40$ & 71.9 & 81 & A & M & i & 2 & $\mathrm{~F}$ & $\mathrm{C}$ & & & $\mathrm{R}$ \\
\hline & $9 \mathrm{H}-2,119$ & 84.89 & 94.49 & A & $\mathrm{M}$ & $i$ & 2 & F & C & & & $\mathrm{R}$ \\
\hline & $9 \mathrm{H}-3,50$ & 72.2 & 81.8 & A & $\mathrm{M}$ & $i$ & 2 & C & C & & & * \\
\hline $9 \mathrm{a}$ & $9 \mathrm{H}-3,100$ & 72.7 & 82.3 & A & M & 1 & 2 & C & C & & & \\
\hline $7 a$ & $9 \mathrm{H}-3,119$ & 72.89 & 82.49 & A & $\mathrm{M}$ & $i$ & 2 & C & $\mathrm{F}$ & & & \\
\hline & $9 \mathrm{H}-4,40$ & 73.6 & 83.2 & A & MG & i & $i$ & c & C & & & $\mathrm{R}$ \\
\hline & $9 \mathrm{H}-4,100$ & 74.2 & 83.8 & A & MG & i & i & $\mathrm{F}$ & A & & & \\
\hline & $9 \mathrm{H}-5,36$ & 75.06 & 84.66 & A & MG & 1 & i & $\mathrm{R}$ & A & & & * \\
\hline & $9 \mathrm{H}-5,119$ & 75.89 & 85.49 & A & M & i & 2 & $\mathrm{x}$ & C & & & \\
\hline $8 b$ & $9 \mathrm{H}-6,40$ & 76.6 & 86.2 & A & MG & i & i & $\ddot{x}$ & $\mathrm{R}$ & & & \\
\hline & $9 \mathrm{H}-6,119$ & 77.39 & 86.99 & A & MG & i & i & $\mathrm{x}$ & $\mathrm{R}$ & & & \\
\hline & $10 \mathrm{H}-1,40$ & 78.6 & 89.2 & A & MG & i & i & & C & & & \\
\hline & $10 \mathrm{H}-1,120$ & 79.4 & 90 & A & MG & i & i & $\mathrm{x}$ & C & * & & \\
\hline $8 a$ & $10 \mathrm{H}-2,47$ & 80.17 & 90.77 & $\hat{A}$ & MG & i & $i$ & $\hat{x}$ & A & & & \\
\hline & $10 \mathrm{H}-2,120$ & 80.9 & 91.5 & A & M & 2 & 2 & 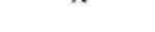 & $\mathrm{F}$ & & & \\
\hline & $10 \mathrm{H}-3,46$ & 81.66 & 92.26 & $\hat{A}$ & MP & 2 & 2 & $\mathrm{x}$ & $\mathrm{F}$ & & & \\
\hline & $10 \mathrm{H}-3,108$ & 82.28 & 92.88 & A & M & 2 & 2 & & C & & & \\
\hline & $10 \mathrm{H}-3,126$ & 82.46 & 93.06 & A & M & 2 & 2 & $\mathrm{x}$ & F & & & \\
\hline & $10 \mathrm{H}-4,10$ & 82.8 & 93.4 & A & M & 2 & 2 & & $\mathrm{~F}$ & & & \\
\hline & $10 \mathrm{H}-4,40$ & 83.1 & 93.7 & A & M & i & 2 & $\mathrm{x}$ & $\mathrm{R}$ & & & \\
\hline & $10 \mathrm{H}-4,85$ & 83.55 & 94.15 & A & M & i & 2 & & $\mathrm{~F}$ & & & \\
\hline & $10 \mathrm{H}-4,150$ & 84.2 & 94.8 & A & MG & i & 1 & $\mathrm{x}$ & F & & & \\
\hline 7 & $10 \mathrm{H}-5,40$ & 84.6 & 95.2 & $\hat{A}$ & MG & i & 2 & $\hat{x}$ & $\mathrm{R}$ & & & \\
\hline & $10 \mathrm{H}-5,120$ & 85.4 & 96 & A & MG & I & 1 & $x$ & $\mathrm{R}$ & & & \\
\hline & $10 \mathrm{H}-6,40$ & 86.1 & 96.7 & A & MG & i & 2 & & & & & \\
\hline & $10 \mathrm{H}-6,120$ & 86.9 & 97.5 & A & MG & i & 2 & $\mathrm{x}$ & $\mathrm{F}$ & & & \\
\hline & $10 \mathrm{H}-7,10$ & 87.3 & 97.9 & A & MG & 1 & 2 & $\mathrm{x}$ & $\mathrm{R}$ & & & \\
\hline & $10 \mathrm{H}-7,20$ & 87.4 & 98 & $\hat{A}$ & MG & $i$ & i & $\mathrm{x}$ & * & & & \\
\hline & $10 \mathrm{H}-7,60$ & 87.8 & 98.4 & A & MG & i & $i$ & $\hat{x}$ & $\mathrm{~F}$ & & & \\
\hline & $11 \mathrm{H}-1,20$ & 87.9 & 100.25 & A & MG & i & 2 & $\hat{x}$ & & & & \\
\hline & $11 \mathrm{H}-1,50$ & 88.2 & 100.55 & A & MG & i & 2 & & $\mathbf{R}$ & & & \\
\hline & $11 \mathrm{H}-1,115$ & 88.85 & 101.2 & A & M & i & 2 & $\mathrm{x}$ & $\mathrm{R}$ & & & \\
\hline & $11 \mathrm{H}-2,35$ & 89.55 & 101.9 & $\hat{A}$ & MG & i & 2 & $\hat{x}$ & $\hat{R}$ & & & \\
\hline 6 & $11 \mathrm{H}-2,120$ & 90.4 & 102.75 & $\hat{A}$ & MG & $i$ & 2 & & & & & \\
\hline & $11 \mathrm{H}-3,40$ & 91.1 & 103.45 & A & MG & 1 & $i$ & $x$ & $\mathrm{R}$ & & & \\
\hline & IIH-3, 120 & 91.9 & 104.25 & A & MG & i & i & & & & & \\
\hline & II $\mathrm{H}-4,40$ & 92.6 & 104.95 & $\hat{A}$ & M & i & 2 & $\mathrm{x}$ & & & & \\
\hline & $11 \mathrm{H}-5,20$ & 93.9 & 106.25 & A & M & i & 2 & $\mathrm{x}$ & & & & \\
\hline & $11 \mathrm{H}-5,50$ & 94.2 & 106.55 & A & M & $i$ & 2 & $x$ & & & & \\
\hline
\end{tabular}

Notes: For an explanation of the abundance and preservation codes, see text. For genus names, see Appendix A. Single asterisk $(*)=$ one specimen observed. A* $=$ dominant species $(50 \%) . \mathrm{X}=$ species present, but not quantitatively evaluated. 
Table 18 (continued).

D. asymmetricus Sphenolithus R.pseudoumbilicus A. delicatus A. primus A. tricorniculatus C. acutus T. rugosus/rioensis D. quinqueramus gr. A. amplificus D. locblichii

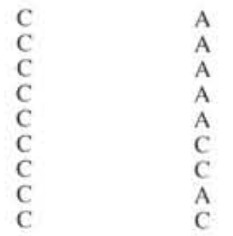

$\begin{array}{ll}\text { F } & \text { R } \\ \text { C } & \text { F } \\ \text { C } & \text { C } \\ \text { F } & \text { C } \\ \text { F } & \text { F } \\ \text { F } & \text { C } \\ \text { R } & \text { R } \\ \text { R } & \text { R }\end{array}$

R

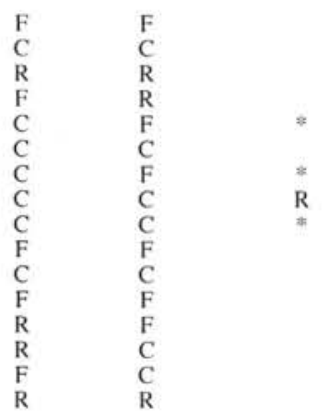

C

$\mathrm{F}$
$\mathrm{R}$
$\mathrm{F}$

$\mathrm{F}$
$\mathrm{R}$
${ }^{*}$
$\mathrm{R}$

$\begin{array}{ll}\text { A } & \text { C } \\ \text { A } & \text { R } \\ \text { A } & \text { R } \\ \text { A } & \text { R } \\ \text { A } & \text { R } \\ \text { A } & \text { R } \\ \text { A } & \text { R } \\ \text { A } & \text { R } \\ \text { A } & \text { R } \\ \text { C } & \\ \text { C } & \\ \text { C } & \\ \text { C } & \\ \text { C } & \\ \text { C } & \\ \text { A } & \end{array}$

F

$\begin{array}{lll}\mathrm{F} & \mathrm{C} & * \\ \mathrm{C} & \mathrm{A} & *\end{array}$

$\mathrm{R}$
$\mathrm{F}$
$\mathrm{R}$

R

*

*
$\mathrm{R}$
$\mathrm{C}$
$\mathrm{R}$
$\mathrm{C}$

*

$\mathrm{C}$
$\mathrm{F}$
$\mathrm{R}$

$\mathrm{A}$
$\mathrm{R}$
$\mathrm{H}$
$\mathrm{R}$
$\mathrm{R}$
$\mathrm{R}$
$\mathrm{A}$

R
$*$
F
C
$*$
$*$
F
R
R
F
R

$\begin{array}{ll}\mathrm{R} & * \\ \mathrm{R} & \mathrm{R} \\ \mathrm{R} & \mathrm{R} \\ \mathrm{F} & \\ \mathrm{R} & * \\ \mathrm{~F} & \mathrm{~F} \\ \mathrm{C} & \mathrm{R} \\ \mathrm{A} & \mathrm{R} \\ \mathrm{A} & \mathrm{F} \\ \mathrm{C} & \mathrm{C} \\ \mathrm{C} & \mathrm{C}\end{array}$

C
F
C
R
R
F
F
F
F
F
C
C
C
C
F
C
C
$A$
$A$
$A$
$A$
$A$
$C$
$C$
$C$
F
R
R
R

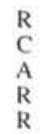


Table 18 (continued).

\begin{tabular}{|c|c|c|c|c|c|c|c|c|c|c|c|}
\hline $\begin{array}{l}\text { Zone } \\
\text { (CN) }\end{array}$ & $\begin{array}{l}\text { Core, section, } \\
\text { interval (cm) }\end{array}$ & M. convallis & D. neohamatus & D. hamatus & C. miopelagicus & C. coalitus & D. exilis & C. leptoporus & C. pelagicus & $\begin{array}{c}\text { Discoaster } \\
\text { in class }\end{array}$ & D. adamanteus \\
\hline & 138-848B- & & & & & & & & & & \\
\hline \multirow{7}{*}{$10 \mathrm{a}$} & $6 \mathrm{H}-6,35$ & & & & & & & A & $\mathrm{F}$ & $R$ & \\
\hline & $6 \mathrm{H}-6.75$ & & & & & & & C & C & $*$ & \\
\hline & $\begin{array}{l}6 \mathrm{H}-7.40 \\
7 \mathrm{H}-1,50\end{array}$ & & & & & & & A & C & $\begin{array}{l}\mathrm{R} \\
\mathrm{F}\end{array}$ & \\
\hline & $7 \mathrm{H}-\mathrm{I} .95$ & & & & & & & A & C & $\mathrm{R}$ & \\
\hline & $7 \mathrm{H}-2,35$ & & & & & & & A & C & $\mathrm{F}$ & \\
\hline & $7 \mathrm{H}-2.120$ & & & & & & & A & A & $\mathrm{R}$ & \\
\hline & $7 \mathrm{H}-3.35$ & & & & & & & $\hat{A}$ & $\hat{A}$ & $\mathrm{~F}$ & \\
\hline \multirow[t]{7}{*}{$9 \mathrm{bC}$} & $7 \mathrm{H}-3,120$ & & & & & & & & & C & \\
\hline & 138-848C- & & & & & & & & & & \\
\hline & $7 \mathrm{H}-1.25$ & & & & & & & & $\mathrm{~F}$ & $\mathrm{~F}$ & $\approx$ \\
\hline & $7 \mathrm{H}-2,25$ & & & & & & & & & C & \\
\hline & $\begin{array}{l}7 \mathrm{H}-2,50 \\
7 \mathrm{H}-3.50\end{array}$ & & & & & & & $C$ & $C$ & $c$ & \\
\hline & $7 \mathrm{H}-3,100$ & & & & & & & C & C & C & $\mathrm{R}$ \\
\hline & $7 \mathrm{H}-4.25$ & & & & & & & C & $\mathrm{C}$ & $\mathrm{C}$ & $\ddot{R}$ \\
\hline \multirow[t]{12}{*}{$9 \mathrm{bB}$} & $7 \mathrm{H}-4,100$ & & & & & & & C & C & * & $\ddot{R}$ \\
\hline & $7 \mathrm{H}-5.25$ & & & & & & & C & $\mathrm{C}$ & $\mathrm{F}$ & s \\
\hline & $7 \mathrm{H}-5,100$ & & & & & & & C & C & $\mathrm{R}$ & $\mathrm{R}$ \\
\hline & $7 \mathrm{H}-6.25$ & & & & & & & C & C & & * \\
\hline & $7 \mathrm{H}-6,100$ & & & & & & & c & C & & * \\
\hline & $7 \mathrm{H}-6.125$ & & & & & & & c & c & & * \\
\hline & $7 \mathrm{H}-6,145$ & & & & & & & C & C & & * \\
\hline & $7 \mathrm{H}-7.20$ & & & & & & & C & C & $\mathrm{R}$ & $\mathrm{R}$ \\
\hline & $7 \mathrm{H}-7.50$ & & & & & & & C & C & F & R \\
\hline & $8 \mathrm{H}-1.80$ & & & & & & & $\mathrm{~F}$ & C & A & R \\
\hline & $8 \mathrm{H}-1.140$ & & & & & & & $\mathrm{~F}$ & c & $\mathrm{c}$ & $\hat{F}$ \\
\hline & $8 \mathrm{H}-2,80$ & & & & & & & c & c & C & * \\
\hline \multirow{12}{*}{$9 \mathrm{bA}$} & $8 \mathrm{H}-2,140$ & & & & & & & c & c & $\mathrm{C}$ & \\
\hline & $8 \mathrm{H}-3,40$ & & & & & & & C & c & C & \\
\hline & $8 \mathrm{H}-3,100$ & & & & & & & c & c & C & * \\
\hline & $8 \mathrm{H}-4.20$ & & & & & & & C & A & A & \\
\hline & $8 \mathrm{H}-4,100$ & & & & & & & $\mathrm{C}$ & $\hat{\mathrm{F}}$ & $\mathrm{c}$ & \\
\hline & $8 \mathrm{H}-5,20$ & & & & & & & C & C & $\mathrm{C}$ & * \\
\hline & $8 \mathrm{H}-5.140$ & & & & & & & C & C & $\mathrm{C}$ & \\
\hline & $8 \mathrm{H}-6.80$ & & & & & & & $\mathrm{C}$ & c & A & \\
\hline & $8 \mathrm{H}-6,140$ & & & & & & & C & C & C & $*$ \\
\hline & $8 \mathrm{H}-7,40$ & & ef & & & & & $\mathrm{C}$ & C & A & * \\
\hline & $9 \mathrm{H}-2.119$ & & of & & & & & C & C & C & $\mathrm{R}$ \\
\hline & $9 \mathrm{H}-3,50$ & & * & & & & & c & C & A & $\mathrm{R}$ \\
\hline \multirow{6}{*}{$9 \mathrm{a}$} & $9 \mathrm{H}-3,100$ & & & & & & & C & C & A & * \\
\hline & $9 \mathrm{H}-3,119$ & & & & & & & C & C & $\mathrm{F}$ & \\
\hline & $9 \mathrm{H}-4,40$ & & & & & & & C & C & C & \\
\hline & $9 \mathrm{H}-4.100$ & & $\mathrm{R}$ & & & & & C & C & & \\
\hline & $9 \mathrm{H}-5,36$ & & & & & & & C & C & C & \\
\hline & $9 \mathrm{H}-5,119$ & * & $\mathrm{R}$ & & & & & $\mathrm{x}$ & $\mathrm{x}$ & A & \\
\hline $8 b$ ? & $9 \mathrm{H}-6.40$ & $\mathrm{R}$ & & & & & & $\mathrm{x}$ & $\mathrm{x}$ & & * \\
\hline & $9 \mathrm{H}-6,119$ & & & & & & & & $x$ & $\mathrm{R}$ & \\
\hline & $10 \mathrm{H}-\mathrm{I}, 40$ & & C & & & & & $\mathrm{x}$ & $\hat{x}$ & R & \\
\hline & $10 \mathrm{H}-1,120$ & $\mathrm{~F}$ & $\mathrm{R}$ & & & & & $\mathrm{x}$ & $\mathrm{x}$ & $\mathrm{R}$ & \\
\hline $8 \mathbf{a}$ & $10 \mathrm{H}-2,47$ & $\mathrm{R}$ & C & & & & & $\hat{x}$ & $\mathrm{x}$ & $\hat{R}$ & \\
\hline & $10 \mathrm{H}-2,120$ & $\mathrm{R}$ & & & & & & $\mathrm{x}$ & $\mathrm{x}$ & & \\
\hline & $10 \mathrm{H}-3,46$ & & $\mathrm{R}$ & & & & & $\mathrm{x}$ & $\mathrm{x}$ & C & \\
\hline & $10 \mathrm{H}-3,108$ & & & & & & & $\hat{x}$ & $\hat{x}$ & C & \\
\hline & $10 \mathrm{H}-3,126$ & & $\mathrm{R}$ & & & & & $\hat{x}$ & $\ddot{x}$ & $\mathrm{~F}$ & \\
\hline & $10 \mathrm{H}-4,10$ & & & & & & & $x$ & $\mathrm{x}$ & & \\
\hline & $10 \mathrm{H}-4,40$ & & & * & & & & $\mathrm{x}$ & $\mathrm{x}$ & & \\
\hline & $10 \mathrm{H}-4.85$ & & & $\mathrm{R}$ & & & & & $\hat{x}$ & $\mathrm{R}$ & \\
\hline & $10 \mathrm{H}-4,150$ & & * & $\mathrm{F}$ & & & & $x$ & $\mathrm{x}$ & $\mathrm{F}$ & \\
\hline 7 & $10 \mathrm{H}-5,40$ & & & $\mathrm{R}$ & & & & & $\mathrm{x}$ & $\mathrm{R}$ & \\
\hline & $10 \mathrm{H}-5,120$ & & & $\mathrm{R}$ & & & & $\mathrm{x}$ & $\mathrm{X}$ & C & \\
\hline & $10 \mathrm{H}-6,40$ & & & $\mathrm{R}$ & & & & $\mathrm{x}$ & C & C & \\
\hline & $10 \mathrm{H}-6.120$ & & & $*$ & & & & $\hat{x}$ & C & C & \\
\hline & $10 \mathrm{H}-7.10$ & & & & & & & $\mathrm{x}$ & $\mathrm{x}$ & C & \\
\hline & $10 \mathrm{H}-7.20$ & & & $\mathrm{R}$ & & * & & $\hat{x}$ & $\mathrm{x}$ & C & \\
\hline & $10 \mathrm{H}-7.60$ & & & & & & & $\mathrm{x}$ & $\mathrm{x}$ & C & \\
\hline & $11 \mathrm{H}-1,20$ & & & & $\mathrm{~F}$ & & & $\hat{x}$ & $\hat{x}$ & $\mathrm{~F}$ & \\
\hline & $11 \mathrm{H}-1.50$ & & & & C & & $\mathrm{F}$ & $\mathrm{x}$ & $\mathrm{x}$ & C & \\
\hline & $11 \mathrm{H}-\mathrm{I}, 115$ & & & & A & & ef & $\hat{x}$ & $\hat{x}$ & C & \\
\hline & $11 \mathrm{H}-2,35$ & & & & A & & & $\hat{x}$ & $\mathrm{x}$ & C & \\
\hline 6 & $11 \mathrm{H}-2,120$ & & & & A & & & $\mathrm{x}$ & $\mathrm{x}$ & C & \\
\hline & IIH-3.40 & & & & A & & & $\hat{x}$ & $\hat{x}$ & C & \\
\hline & $11 \mathrm{H}-3,120$ & & & & A & & & $\mathrm{x}$ & $\mathrm{x}$ & C & \\
\hline & II $-4,40$ & & & & $\hat{A}$ & & & $\hat{x}$ & $\hat{x}$ & C & \\
\hline & $11 \mathrm{H}-5,20$ & & & & A & & & $\mathrm{x}$ & $\mathrm{x}$ & C & \\
\hline & IIH $-5,50$ & & & & A & & & $\hat{x}$ & $\mathrm{x}$ & C & \\
\hline
\end{tabular}

Notes: For an explanation of the abundance and preservation codes, see text. For genus names, see Appendix A. Single asterisk $(*)=$ one specimen observed. A* $=$ dominant species $(50 \%), \mathrm{X}=$ species present, but not quantitatively evaluated. 
Table 18 (continued).

D. bellus gr, D. calcaris D. hamatus-bellus D. intercalaris D. moorei D. prepentaradiatus D. variabilis H. carteri gr. Reticulofenestrids T. extensus

R

C

R

R

$\mathrm{R}$
$\mathrm{F}$
$\mathrm{A}$
$\mathrm{C}$
$\mathrm{A}$
$\mathrm{A}^{*}$
$\mathrm{~A}$
$\mathrm{C}$
$?$
$\mathrm{R}$
$\mathrm{R}$
$\mathrm{F}$
$\mathrm{cf}$
$\mathrm{R}$
$\mathrm{R}$
$\mathrm{C}$
$\mathrm{C}$
$\mathrm{A}$
$\mathrm{R}$
$\mathrm{A}$
$\mathrm{A}$
$\mathrm{F}$
$\mathrm{R}$
$\mathrm{F}$
$\mathrm{C}$
$\mathrm{R}$

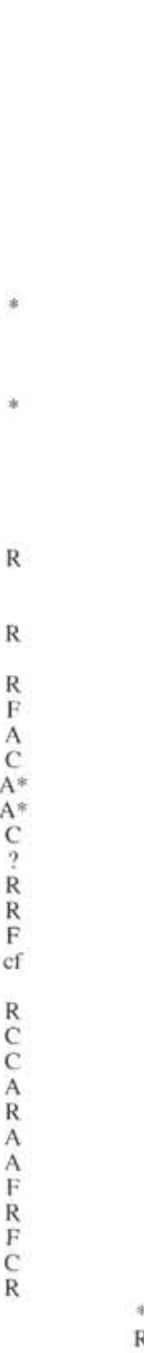

F

$\mathrm{R}$
$\mathrm{R}$
$\mathrm{R}$

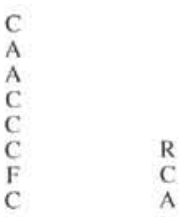

R
R
C
A

A

$\mathrm{F}$
$\mathrm{C}$
$\mathrm{C}$
$\mathrm{R}$
$\mathrm{C}$
$\mathrm{F}$
$\mathrm{R}$
$\mathrm{C}$
$\mathrm{C}$
$\mathrm{C}$
$\mathrm{A}$
$\mathrm{C}$
$\mathrm{C}$
$\mathrm{A}$
$\mathrm{A}$
$\mathrm{C}$
$\mathrm{C}$
$\mathrm{F}$
$\mathrm{C}$
$\mathrm{C}$
4
$\mathrm{~F}$
$\mathrm{C}$
$\mathrm{R}$
$\mathrm{C}$
$\mathrm{F}$
$\mathrm{F}$
$\mathrm{F}$
$\mathrm{F}$
$\mathrm{C}$
$\mathrm{A}$
$\mathrm{C}$
$\mathrm{C}$
$\mathrm{C}$
$\mathrm{R}$
क
$\mathrm{F}$
$\mathrm{R}$
$\mathrm{F}$

R
C
R
C
C
F
F
R
R
F
F
C
C
cf
C 
lowest occurrence of $C$. coalitus was directly calibrated to the magnetostratigraphy at Site 845 as occurring in the lower part of Chron $5 \mathrm{n} .2 \mathrm{n}$ (age estimate of $10.7 \mathrm{Ma}$ ).

Moreover, in the Miocene interval, we discussed supplementary events that improve upon the biostratigraphic resolution provided by the standard zonations.

In the upper Miocene interval, the stratigraphic relationship of the lowest and highest occurrences of A. amplificus relative to the events B A. primus and T D. quinqueramus allowed us to divide further a rather long time interval (about 1.7 m.y.), corresponding to Subzone $\mathrm{CN} 9 \mathrm{~b}$, into three distinguishable biostratigraphic subunits. The lowest and highest occurrences of $A$. amplificus were calibrated to the magnetostratigraphy at Sites $844,845,852$, and 853 as occurring at the bottom and top of Chron $3 \mathrm{An}$, respectively, and are isochronous with the occurrence of $A$. amplificus in the western equatorial Indian Ocean (Rio et al., 1990a). In the interval between lower Subzone $\mathrm{CN} 9 \mathrm{~b}$ and Zone $\mathrm{CN} 8$, we observed a significant turnover within the placoliths, corresponding to the temporary and almost complete disappearance of large specimens $(>7 \mu \mathrm{m})$ of $R$. pseudoumbilicus. This interval seems to have a wide geographical extent, as it has also been observed in the western equatorial Indian Ocean (Young, 1990; Rio et al., 1990a) at a similar stratigraphic level. This turnover is thought to reflect oceanographic-climatic instability (Rio et al., 1990a).

In the middle Miocene interval, the following additional events were recorded within Zone CN5 (from the top): T $C$. nitescens, T $C$. premacintyrei, B T. rugosus, T D. signus, and T C. floridanus. The T C. floridanus event is easily detected in Leg 138 material and is recorded above the highest occurrence of $S$. heteromorphus and well below the lowest occurrence of $D$. kugleri. This finding supports the contention that the final range of $C$. floridanus is biogeographically controlled, as shown by Olafsson (1991) and Fornaciari et al. (1993). The lowest occurrence of $D$. kugleri was recognized and used to place the boundary between Subzones CN5b and CN5a by means of a quantitative analysis on closely spaced samples. This marker species is generally rare and scattered in most of its range, except for a brief interval in which it is common and continuously distributed. This interval with common and typical $D$. kugleri is correlatable between all different sequences and was calibrated as occurring within Chron 5r (estimated age interval: 11.3-11.9 Ma) at Site 845. At this same site, the other nannofossil events of Zone CN5 have also been calibrated to the magnetostratigraphic record.

In the lower Miocene interval, corresponding to the uppermost part of Zone $\mathrm{CN} 3$, we detected the acme end of $D$. deflandrei and the lowest occurrence of $D$. signus, which have similar stratigraphic positions in the western equatorial Indian Ocean (Rio et al., 1990a).

\section{TAXONOMIC NOTES}

A complete list of taxa considered in the present study is reported in Appendix A. We followed the taxonomic concepts explained in Rio et al. (1990a); concepts concerning the most important taxa are summarized below. Species representatives of genera Dictyococcites, Pontosphaera, Rhabdosphaera, Scyphosphaera, Syracosphaera, Toracosphaera, and Umbilicosphaera are grouped under the single genus epithet in the range charts.

\section{Gephyrocapsids}

Rio (1982) and Rio et al. (1990b) have shown that gephyrocapsids can be consistently used for biostratigraphic purposes, and Raffi et al, (1993) and Rio et al. (in press) have shown that they provide an accurate and precise tool for correlation in early Pleistocene sequences. In the material studied, the taxonomic concepts followed for recognition in light microscope of gephyrocapsids are those summarized in Raffi et al. (1993). They discriminate within the group the following biometrically based taxonomic entities:

1. Gephyrocapsids <4 $\mu \mathrm{m}$ in size, "small Gephyrocapsa spp.";

2. Gephyrocapsids $\geq 4 \mu \mathrm{m}$ and $\leq 5.5 \mu \mathrm{m}$ in size, with an open central area, "medium Gephyrocapsa spp.":

3. Gephyrocapsids $>5.5 \mu \mathrm{m}$ in size, labeled "large Gephyrocapsa spp."
Within the medium-sized gephyrocapsids, there are morphotypes with an open central area and a bridge nearly aligned with the short axis of the placolith, similar to $G$. oceanica as intended by many authors. These gephyrocapsids are comparable to $G$. omega Bukry (=syn. G. parallela Hay and Beaudry) and make up a large proportion of the medium-sized gephyrocapsid stock that reappeared in the lower Pleistocene after the interval of temporary disappearance of medium-sized forms.

\section{Reticulofenestrids}

Within reticulofenestrids, we distinguished the following species and groups: "circular reticulofenestrids," Reticulofenestra spp., and $R$. pseudoumbilicus.

To "circular reticulofenestrids," we ascribed forms that are 5-8.5 $\mu \mathrm{m}$ in size, with a circular outline and relatively large central opening, known as $R$. rotaria Theodoridis or $R$. pseudoumbilicus var. rotaria Young. These reticulofenestrids seem restricted to late Miocene.

Reticulofenestra spp. includes the small-sized reticulofenestrids $R$. haqii, R. minuta, and $R$. minutula.

For distinguishing $R$. pseudoumbilicus, we followed taxonomic concepts of Raffi and Rio (1979) and Backman and Shackleton (1983), and considered adding to this species reticulofenestrids larger than $7 \mu \mathrm{m}$. In the eastern equatorial Pacific, $R$. pseudoumbilicus appears at the boundary between Zones $\mathrm{CN} 4$ and $\mathrm{CN} 5$, and has low abundance in its lower range. It becomes a dominant element of nannofossil assemblages in Zone CN5. These reticulofenestrids virtually disappears from the stratigraphic record for a long interval in the late Miocene. The Pliocene extinction of large $R$. pseudoumbilicus is a clear event in the Leg 138 material, which occurs in the upper part of Chron 2Ar (late Gilbert), as it does in other areas (Backman and Shackleton, 1983; Rio et al., 1990a, 1990b).

\section{Calcidiscus}

We ascribed to $C$. macintyrei species only circular Calcidiscus specimens equal to or larger than $11 \mu \mathrm{m}$, using the " $10-\mu \mathrm{m}$ size" as a break point to make the distinction between $C$. leptoporus and $C$. macintyrei (see discussion in Fornaciari et al., 1990). Following this taxonomic concept, in the equatorial Indian Ocean (Fornaciari et al., 1990), the first appearance of $C$. macintyrei occurs within Zone CN5, at a higher stratigraphic level than that indicated by Bukry (1978). In the middle Miocene of the eastern equatorial Pacific, C. macintyrei is very rare and discontinuously present in the lower part of its range.

Elliptical Calcidiscus referred to Calcidiscus premacintyrei are consistently present in Zones $\mathrm{CN} 3$ and $\mathrm{CN} 4$, and become extinct in the upper part of Subzone CN5a.

\section{Discoasterids}

Discoasterids recorded in the sediments of Leg 138 show variable distribution and preservation patterns between the different sites and at different stratigraphic intervals. Rich and well-preserved discoasterid assemblages have been observed mainly at sites located out of the equatorial divergence zone and out of the influence of upwelling. Overgrown discoasterids were recorded in the Miocene interval, making the identification of the different species difficult and sometimes impossible, particularly within the lower and middle Miocene nannofossil assemblages.

\section{Pliocene Discoasterids}

Pliocene discoasterid species were identified following concepts outlined in Backman and Shackleton (1983). In this time interval, the assemblages are dominated by Discoaster brouweri. D. pentaradiatus is common or abundant in the early Pliocene; Discoaster surculus, D. variabilis, D. decorus, D. tristellifer, and, overall, D. tamalis and D. asymmetricus are subordinate.

\section{Late-early Miocene through late Miocene Discoasterids}

The massive six-rayed forms, which characterize discoasterid assemblages in the early and middle Miocene, were replaced by slender forms with bifurcated and pointed tips in the late Miocene. This turnover in the discoasterid assemblages, which took place gradually within the late-middle Miocene, is particularly evidenced by the appearance in the stratigraphic record of five-rayed discoasterids. The species of five-rayed discoasterids observed in the eastern equatorial Pacific are the $D$. bellus group, D. hamatus, D. berggrenii, D. quinqueramus and Discoaster sp. 1 (sensu Rio et al., 1990a).

Specimens belonging to Discoaster bellus gr. are characterized by small size $(6-8 \mu \mathrm{m})$ and poorly developed central area. Morphotypes with intergrade 
morphologic features between $D$. bellus and $D$. hamatus and between $D$. bellus and $D$. berggrenii are included in the group.

Discoaster hamatus is characterized by five long rays with a spine extending and bending sharply near the tips (Plate 1, Fig. 1). Specimens relatively thin and smaller $(8-10 \mu \mathrm{m}$ in size) than standard have been observed in the material studied.

To $D$. berggrenii, we ascribed forms even with a poorly developed central knob, with a distinct central area, following Rio et al. (1990a). In the material studied, $D$. berggrenii appears and becomes extinct earlier than $D$. quinqueramus, according to Bukry (1971); in the range charts, the two species were lumped together because intergrades between typical $D$. berggrenii and $D$. quinqueramus are commonly recorded. Large specimens of $D$. quinqueramus (about $16 \mu \mathrm{m}$ ) were observed in the final range of the species. Small five-rayed discoasterids, which are common and continuously distributed up to the highest occurrence of D. quinqueramus, are referred to as Discoaster sp. 1 (Plate 2, Fig. 5). This form is smaller in size than $D$, berggrenii and $D$. quinqueramus $(6-8 \mu \mathrm{m}$ vs. $8-15 \mu \mathrm{m})$ and has a poorly developed central area with a very small knob (see Rio et al., 1990a, pl. 2, fig. 9).

The six-rayed species of slender discoasterids with pointed tips considered here are $D$. braarudii, $D$. brouweri, $D$. intercalaris, $D$. neohamatus, $D$. neorectus, and Discoaster sp. 2 (sensu Rio et al., 1990a). D. braarudii and D. neorectus are found with rare and scattered specimens; the medium-sized $D$. intercalaris is rather common, but it occurs discontinuously. The first and rare D. brouweri appears in the upper part of Subzone CN5, and becomes common and continuously distributed in Zone CN7. In the eastern equatorial Pacific, within Subzones CN9a and CN9b (lower part), we observed a large discoasterid $(20-30 \mu \mathrm{m}$ in size) morphologically similar to $D$. brouweri and referred to as Discoaster sp. 2 (Plate 2, Figs. 6-7), which was observed by Rio et al. (1990a) in the equatorial Indian Ocean. In the material studied, it is rare and discontinuous, and does not provide a meaningful biostratigraphic signal.

D. neohamatus was easily recognized, even in overgrown assemblages. The feature of its long pointed rays is a "spine" at tips, which sharply bends in one direction; it can be recognized even in strongly overgrown specimens. It is less protruding in specimens found in the terminal range of the species, where intergrade forms between $D$, brouweri and $D$. neohamatus were observed.

Among slender discoasterids with bifurcating rays, we considered the groups of five-rayed ( $D$. moorei, $D$. pentaradiatus, and $D$. prepentaradiatus) and six-rayed (D. bollii, D. calcaris, $D$. aff. calcaris, D. challengeri, D. exilis, D. icarus, D. loeblichii, D. pansus, D. perclarus, D. pseudovariabilis, D. surculus, D. subsurculus, D. signus, D. tuberi, and D. variabilis) discoasterids. The four-rayed species D. blackstockae is found only in spot samples with single specimens.

D. moore is easily recognized by its asymmetrical rays, even in overgrown assemblages, and it is distributed scattered and in low abundances from Zones $\mathrm{CN} 3$ to $\mathrm{CN} 6$. D. prepentaradiatus was distinguished from $D$. pentaradiatus for the poorly developed central area and for the shape of its arms, which are shorter and bend downward and lack birefringence. $D$. pentaradiatus shows a certain degree of morphologic variability, consisting in arms more or less slender and bifurcations more or less developed.

Among six-rayed bifurcating discoasterids, some species are not easily differentiated because many intergrading forms exist. The classifications of $D$. variabilis and $D$. surculus take into account their high degree of variability in morphologic features. D. perclarus and D. icarus are found to be very rare and scattered. Typical $D$. calcaris (Plate 1, Fig. 2) is common and has restricted range in intervals close (just below) the lowest occurrence of $D$. hamatus. $D$. aff. calcaris is a discoasterid observed and described by Rio et al. (1990a; see pl. 7, figs. 4-6) in the equatorial Indian Ocean. We found this form as rare and scattered within Subzone CN5b. We could not distinguish $D$. signus and $D$. tuberi, the observed specimens having often the tips of bifurcated rays broken. Therefore, we designated with a single species epithet, D. signus, those discoasterids with characteristic central prominent knob, recognizable even in strongly overgrown assemblages.

The middle Miocene discoasterid assemblage is characterized by six-rayed forms belonging to $D$. musicus $(=D$. sanmiguelensis $)$ and $D$. kugleri group, having a broad central area of variable size, larger than the length of the rays; species circumscription within this group is sometimes difficult when overgrowth is present. In the material studied, D. kugleri (Plate 1, Figs. 3-5) is present with typical specimens having a flat central area that lacks the large star-shaped knob of D. musicus specimens.

Another middle Miocene form observed is the small discoasterid $D$. adamanteus, recognized even in strongly overgrown assemblages, where, on the contrary, it was difficult to distinguish species like $D$. aulakos, $D$. variabilis, and $D$. exilis. The same problems of identification arose in the early Miocene interval, in which discoasterids are generally poorly preserved.
Distinction within $D$. dilatus $-D$, extensus group proved impossible, whereas the $D$. deflandrei group was discriminated, sometimes with difficulty. This group dominates the assemblages of the upper part of the early Miocene.

\section{Ceratolithids}

The horseshoe-shaped nannofossils belonging to the Ceratolithaceae family are a minor but distinctive component of the assemblages during the latest Miocene and early Pliocene. In the Leg 138 material, ceratolithids are present with variable abundances and are found overall at sites located north of the equatorial zone. In these sequences, qualitative observations on rich and well-preserved assemblages helped to clarify the phylogenetic relationship of the group. Appearance and extinction events of members of the ceratolithid group provide meaningful biostratigraphic signals in the late Neogene (summarized below, listed in stratigraphic succession).

Late Miocene ceratolithid events are as follows:

1. B (bottom occurrence of) A. primus,

2. B A. delicatus,

3. B A. amplificus, and

4. T (top occurrence of) A. amplificus.

Early Pliocene ceratolithid events are as follows:

5. B C. acutus,

6. B C. armatus,

7. B C. rugosus,

8. T C. acutus,

9. T C. armatus, and

10. T A. primus, A. delicatus, and A. tricorniculatus.

The first representative of the group is the species A. primus, within which two morphotypes can be distinguished. The primitive specimens are comparable with the holotype (see Bukry and Percival, 1971, pl. 1, fig. 12), have a thick arch, and evolve rapidly to more delicate crescent-shaped forms, which occur together with another delicate species, A. delicatus. In the material studied, the distinction between these two morphotypes is clear but does not seem to be stratigraphically useful, as they occur closely one after the other.

An interesting finding in some Leg 138 successions was the observation of transitional forms between Triquetrorhabdulus rugosus-T. extensus and A. primus, observed close to the appearance level of ceratolithids. The presence of such intergrading forms (Plate 3, Figs. 3, 4, and 6) confirms previous suggestions of a phylogenetic relationship between Triquetrorhabdulus and Amaurolithus (Gartner, 1967; Perch-Nielsen, 1977, 1985). A similar phylogenetic relationship was documented also at higher levels, where we observed nannofossils with transitional morphological features between T. extensus and A. amplificus (Plate 3, Figs. 7-8) just below the appearance of A. amplificus. Gartner and Bukry (1975) pointed out that the robust and asymmetrical A. amplificus could be related to $A$. primus and $A$. delicatus, although such a relationship is unclear. The presence of the intergrading forms indicates that A. amplificus probably evolved directly from Triquetrorhabdulus. These intergrading forms are also present within the range of typical A. amplificus and in the equatorial Indian Ocean (Rio et al., 1990a). The stratigraphic range of $A$. amplificus in the eastern equatorial Pacific is restricted to Chron $3 \mathrm{An}$, as in the equatorial Indian Ocean (Rio et al., 1990a; Raffi et al., this volume).

A. tricorniculatus, an asymmetrical delicate ceratolithid with a pronounced apical spine, occurs discontinuously with rare specimens in sediments of the investigated sections; intergrade forms between A. primus, A. delicatus, and A. tricorniculatus are rather common.

Similar intergrading between different species was observed among the birefringent ceratolithids $C$. acutus, $C$. armatus, $C$. rugosus, $C$. cristatus, and C. telesmus. Therefore, species assignments and recognition of some events were sometimes difficult, and were also hindered by overgrowth problems. For this reason, we could not confidently recognize the events B C. armatus and T C. armatus; the event T C. acutus was also difficult to detect.

We point out the finding of forms that seem related to ceratolithids (shown in Plate 4, Figs. 5-7). These are birefringent rod-shaped forms, similar to species of the lower Cretaceous genus Ceratolithina (see Perch-Nielsen, 1988), and were found as rare and scattered in the lower part of Zone CN7 (NN9). Similar forms were also observed by one of us (I.R.) at Sites 710 and 714 in the western equatorial Indian Ocean in the same stratigraphic interval.

\section{Triquetrorhabdulids}

Species ascribed to the genus Triquetrorhabdulus observed in Leg 138 Miocene sediments are T. extensus, T. milowii, T. rugosus, and T. serratus. 
$T$. rioensis and $T$. farnsworthii were included in the taxonomic unit $T$. rugosus, as $T$. rioensis has the same stratigraphic distribution as $T$. rugosus, and $T$. farnsworthii was considered a well-preserved morphotype of $T$. rugosus, common in the upper part of its range. T. extensus was found in the upper Miocene interval together with intergrade forms between Amaurolithus species (see above).

T. milowii was found to be rare and sporadic. T. serratus is common in the lower and middle Miocene interval, and disappears within Subzone CN5a, just above the appearance of $T$. rugosus.

\section{Helicoliths}

Helicolith nannofossils, which are not solution resistant, occur continuously in most of the Leg 138 sequences. Helicoliths are missing or represented by strongly etched specimens in the intervals where dissolution affects nannofossil assemblages, as in the upper Miocene and lower Pliocene intervals at Sites 844 and 845.

The species recognized are listed in Appendix A. Among them, we included into the group of $H$. carteri specimens with slightly variable morphology. In the late early Miocene, $H$. ampliaperta is generally rare but clearly distinguishable within the helicolith assemblage dominated by $\mathrm{H}$. intermedia, recorded up to Zone CN5, and $H$. gramulata.

\section{Sphenoliths}

Sphenoliths are a major constituent of the Miocene and early Pliocene nannofossil assemblages of the eastern equatorial Pacific. We observed characteristic high-abundance intervals (blooms) of these nannoliths in the Leg 138 sequences. The simultaneous extinction of $S$. abies and $S$. neoabies in the Pliocene (Backman and Shackleton, 1983) provides a useful event; the two species have been grouped together with $S$. moriformis and $S$. compactus (as Sphenolithus spp.) in the range charts, as differentiations among these species are not always clear. The typical spined sphenolith $S$. heteromorphus is abundant in the material studied, and its extinction event provides a neat biostratigraphic signal in the middle Miocene.

\section{ACKNOWLEDGMENTS}

We would like to thank J. Backman and D. Rio for their critical reviews, comments, and suggestions, which improved the quality of this paper. Special thanks go to J.W. Farrell and A. Sposato for the help given in some phases of this work. Funding for this study was provided by CNR Grant No. AI91.00913.05 to I. Raffi.

\section{REFERENCES}

Aguirre, E., and Pasini, G., 1985. The Pliocene-Pleistocene boundary. Episodes, $8: 11-120$.

Aubry, M.-P., 1984. Handbook of Cenozoic Calcareous Nannoplankton (Book 1): Ortholithae (Discoasters): New York (Micropaleontology Press).

, 1988. Handbook of Calcareous Nannoplankton (Book 2): Ortholithae (Catinasters, Ceratoliths, Rhabdoliths): New York (Micropaleontology Press).

1989. Handbook of Cenozoic Calcareous Nannoplankton (Book 3): Ortholithae (Pentaliths and Others). Heliolithae (Fasciculiths, Sphenoliths, and Others): New York (Micropaleontology Press).

, 1990. Handbook of Cenozoic Calcareous Nannoplankton (Book 4): Heliolithae (Helicoliths, Cribriliths, Lopadoliths, and Others): New York (Micropaleontology Press).

Backman, J., and Pestiaux, P., 1987. Pliocene Discoaster abundance variations, Deep Sea Drilling Project Site 606: biochronology and paleoenvironmental implications. In Ruddiman, W.F., Kidd, R.B., Thomas, E., et al., Init. Repts. DSDP, 94 (Pt. 2): Washington (U.S. Govt. Printing Office), 903-910.

Backman, J., Schneider, D.A., Rio, D., and Okada, H., 1990. Neogene lowlatitude magnetostratigraphy from Site 710 and revised age estimates of Miocene nannofossil datum events. In Duncan, R.A., Backman, J.,

\footnotetext{
Abbreviations for names of organizations and publication titles in ODP reference lists follow the style given in Chemical Abstracts Service Source Index (published by American Chemical Society).
}

Peterson, L.C., et al., Proc. ODP, Sci. Results, 115: College Station, TX (Ocean Drilling Program), 271-276.

Backman, J., and Shackleton, N.J., 1983. Quantitative biochronology of Pliocene and early Pleistocene calcareous nannofossils from the Atlantic, Indian and Pacific oceans. Mar. Micropaleontol., 8:141-170.

Bergen, J.A., 1984. Calcareous nannoplankton from Deep Sea Drilling Project Leg 78A: evidence for imbricate underthrusting at the Lesser Antillian active margin. In Biju-Duval, B., Moore, J.C., et al., Init. Repts. DSDP, 78 (Pt. 1): Washington (U.S. Govt. Printing Office), 411-445.

Berggren, W.A., Kent, D.V., and Van Couvering, J.A., 1985. The Neogene: Part 2. Neogene geochronology and chronostratigraphy. In Snelling, N.J. (Ed.), The Chronology of the Geological Record. Geol. Soc. London Mem., 10:211-260.

Bukry, D., 1971. Discoaster evolutionary trends. Micropaleontology, 17:4352.

1973. Low-latitude coccolith biostratigraphic zonation. In Edgar, N.T., Saunders, J.B., et al., Init. Repts. DSDP, 15: Washington (U.S. Govt. Printing Office), 685-703.

1975. Coccolith and silicoflagellate stratigraphy, northwestern Pacific Ocean, Deep Sea Drilling Project Leg 32. In Larson, R.L., Moberly, R., et al., Init. Repts. DSDP, 32: Washington (U.S. Govt. Printing Office), 677-701.

1978. Biostratigraphy of Cenozoic marine sediment by calcareous nannofossils. Micropaleontology, 24:44-60.

1991. Paleoecological transect of western Pacific Ocean late Pliocene coccolith flora. Part I: Tropical Ontong-Java Plateau at ODP 806B. Open-File Rep.-U.S. Geol. Surv., 91-552:1-35.

Bukry, D., and Percival, S.F., 1971. New Tertiary calcareous nannofossils. Tulane Stud. Geol. Paleontol., 8:123-146.

Cande, S.C., and Kent, D.V., 1992. A new geomagnetic polarity time scale for the Late Cretaceous and Cenozoic. J. Geophys. Res., 97:13917-13951.

Channell, J.E.T., Rio, D., and Thunell, R.C., 1988. Miocene/Pliocene boundary magnetostratigraphy at Capo Spartivento, Calabria, Italy. Geology, 16:1096-1099.

Chepstow-Lusty, A., Backman, J., and Shackleton, N.J., 1989. Comparison of upper Pliocene Discoaster abundance variations from North Atlantic Sites $552,607,658,659$ and 662 : further evidence for marine plankton responding to orbital forcing. In Ruddiman, W.F., Sarnthein, M., et al., Proc. ODP, Sci. Results, 108: College Station, TX (Ocean Drilling Program), 121-141.

Chepstow-Lusty, A., Shackleton, N.J., and Backman, J., 1992. Upper Pliocene Discoaster abundance from the Atlantic, Pacific, and Indian oceans: the significance of productivity pressure at low latitudes. Mem. Sci. Geol., 44:357-373.

Cita, M.B., and Premoli Silva, I., 1968. Evolution of the planktonic foraminiferal assemblages in the stratigraphical interval between the typeLanghian and the type-Tortonian and biozonation of the Miocene of Piedmont. G. Geol., 35:1-23.

Ellis, C.H., 1982. Calcareous nannoplankton biostratigraphy-Deep Sea Drilling Project Leg 60. In Hussong, D.M., Uyeda, S., et al., Init. Repts. DSDP, 60: Washington (U.S. Govt. Printing Office), 507-535.

Fornaciari, E., Backman, J., and Rio, D., 1993. Quantitative distribution patterns of selected lower to middle Miocene calcareous nannofossils from the Ontong Java Plateau. In Berger, W.H., Kroenke, L.W., Mayer, L.A., et al., Proc. ODP, Sci. Results, 130: College Station, TX (Ocean Drilling Program), 245-256.

Fornaciari, E., Raffi, I., Rio, D., Villa, G., Backman, J., and Olafsson, G., 1990. Quantitative distribution patterns of Oligocene and Miocene calcareous nannofossils from the western equatorial Indian Ocean. In Duncan, R.A., Backman, J., Peterson, L.C., et al., Proc. ODP, Sci. Results, 115: College Station, TX (Ocean Drilling Program), 237-254.

Gartner, S., 1967. Calcareous nannofossils from Neogene of Trinidad, Jamaica, and Gulf of Mexico. Univ. Kansas Paleontol. Contrib., 29.

1977. Calcareous nannofossil biostratigraphy and revised zonation of the Pleistocene. Mar. Micropaleontol., 2:1-25.

1992. Miocene nannofossil chronology in the North Atlantic, DSDP Site 608. Mar. Micropaleontol., 18:307-331.

Gartner, S., and Bukry, D., 1975. Morphology and phylogeny of the coccolithophycean family Ceratolithaceae. J. Res. U.S. Geol. Surv., 3:451-465.

Gartner, S., and Chow, J., 1985. Calcareous nannofossil biostratigraphy, Deep Sea Drilling Project Leg 85, eastern equatorial Pacific. In Mayer, L., Theyer, F., Thomas, E., et al., Init. Repts. DSDP, 85: Washington (U.S. Govt. Printing Office), 609-619. 
Hagelberg, T., Shackleton, N., Pisias, N., and Shipboard Scientific Party, 1992. Development of composite depth sections for Sites 844 through 854 . In Mayer, L., Pisias, N., Janecek, T., et al., Proc. ODP, Init. Repts., 138 (Pt. 1): College Station, TX (Ocean Drilling Program), 79-85.

Hey, R., 1977. Tectonic evolution of the Cocos-Nazca spreading center. Geol. Soc. Am. Bull., 88:1404-1420.

Hilgen, F.J., 1991a. Astronomical calibration of Gauss to Matuyama sapropels in the Mediterranean and implication for the Geomagnetic Polarity Time Scale. Earth Planet. Sci. Lett., 104:226-244.

, 1991b. Extension of the astronomically calibrated (polarity) time scale to the Miocene-Pliocene boundary. Earth Planet. Sci. Lett., 107:349-368.

Hilgen, F.J., and Langereis, C.G., 1988. The age of the Miocene-Pliocene boundary in the Capo Rossello area (Sicily). Earth Planet. Sci. Lett., 91:214-222.

Loeblich, A.R., and Tappan, H., 1966. Annotated index and bibliography of the calcareous nannoplankton. Phycologia, 5:81-215.

1968. Annotated index and bibliography of the calcareous nannoplankton II. J. Paleontol., 42:584-598.

, 1969. Annotated index and bibliography of the calcareous nannoplankton III. J. Paleontol., 43:568-588.

1970a. Annotated index and bibliography of the calcareous nannoplankton IV. J. Paleontol., 44:558-574.

1970b. Annotated index and bibliography of the calcareous nannoplankton V. Phycologia, 9:157-174.

, 1971. Annotated index and bibliography of the calcareous nannoplankton VI. Phycologia, 10:315-339.

, 1973. Annotated index and bibliography of the calcareous nannoplankton VII. J. Paleontol., 47:715-759.

Martini, E., 1971. Standard Tertiary and Quaternary calcareous nannoplankton zonation. In Farinacci, A. (Ed.), Proc. 2nd Int. Conf. Planktonic Microfossils Roma: Rome (Ed. Tecnosci.), 2:739-785.

Mayer, L., Pisias, N., Janecek, T., et al., 1992. Proc. ODP, Init. Repts., 138 (Pts. 1 and 2): College Station, TX (Ocean Drilling Program).

Mayer, L.A., Shipley, T.H., and Winterer, E.L., 1986. Equatorial Pacific seismic reflectors as indicators of global oceanographic events. Science, 233:761-764.

Mazzei, R., Raffi, I., Rio, D., Hamilton, N., and Cita, M.B., 1979. Calibration of late Neogene calcareous plankton datum planes with the paleomagnetic record of Site 397 and correlation with Moroccan and Mediterranean sections. In von Rad, U., Ryan, W.B.F., et al., Init. Repts. DSDP, 47 (Pt. 1): Washington (U.S. Govt. Printing Office), 375-389.

Okada, H., and Bukry, D., 1980. Supplementary modification and introduction of code numbers to the low-latitude coccolith biostratigraphic zonation (Bukry, 1973; 1975). Mar. Micropaleontol., 5:321-325.

Olafsson, G., 1989. Quantitative calcareous nannofossil biostratigraphy of upper Oligocene to middle Miocene sediment from ODP Hole 667 A and middle Miocene sediment from DSDP Site 574. In Ruddiman, W., Sarnthein, M., et al., Proc. ODP, Sci. Results, 108: College Station, TX (Ocean Drilling Program), 9-22.

1991. Quantitative calcareous nannofossil biostratigraphy and biochronology of early through late Miocene sediments from DSDP Hole 608. Medd. Stockholms Univ. Inst. Geol. Geok., 285.

Parker, M.E., Clark, M., and Wise, S.W., Jr. 1985. Calcareous nannofossils of Deep Sea Drilling Project Sites 558 and 563, North Atlantic Ocean: biostratigraphy and the distribution of Oligocene braarudosphaerids. In Bougault, H., Cande, S.C., et al., Init. Repts. DSDP, 82: Washington (U.S. Govt. Printing Office), 559-589.

Perch-Nielsen, K., 1977. Albian to Pleistocene calcareous nannofossils from the western South Atlantic, DSDP Leg 39. In Supko, P.R., Perch-Nielsen, K., et al., Init. Repts. DSDP, 39: Washington (U.S. Govt. Printing Office), 699-823.

, 1985. Cenozoic calcareous nannofossils. In Bolli, H.M., Saunders, J.B., and Perch-Nielsen, K. (Eds.), Plankton Stratigraphy: Cambridge (Cambridge Univ. Press), 427-554.

1988. New Lower Cretaceous calcareous nannofossil species from England. INA Newsl., 10:30-36.

Proto Decima, F., Medizza, F., and Todesco, L., 1978. Southeastern Atlantic Leg 40 calcareous nannofossils. In Bolli, H.M., Ryan, W.B.F., et al., Init. Repts. DSDP, 40: Washington (U.S. Govt. Printing Office), 571-634.

Raffi, I., Backman, J., Rio, D., and Shackleton, N.J., 1993. Plio-Pleistocene nannofossil biostratigraphy and calibration to oxygen isotopes stratigraphies from Deep Sea Drilling Project Site 607 and Ocean Drilling Program Site 677. Paleoceanography, 8:387-408.
Raffi, I., and Rio, D., 1979. Calcareous nannofossil biostratigraphy of DSDP Site 132-Leg 13 (Tyrrhenian Sea-Western Mediterranean). Riv. Ital. Paleontol. Stratigr., 85:127-172.

Ramsay, A.T.S., 1972. Aspects of the distribution of fossil species of calcareous nannoplankton in North Atlantic and Caribbean sediments. Nature, 236:67-70.

1977. Sedimentological clues to paleoceanography. In Ramsay, A.T.S. (Ed.), Oceanic Micropaleontology (Vol. 2): New York (Academic Press), 1371-1453.

Ramsay, A.T.S., Schneidermenn, N., and Finch, J.W., 1973. Fluctuations in the past rates of carbonate solution at Site 149: a comparison with other ocean basins and an interpretation of their significance. $\ln$ Edgar, N.T., Saunders, J.B., et al., Init. Repts. DSDP, 15: Washington (U.S. Govt. Printing Office), $805-811$.

Rio, D., 1982. The fossil distribution of coccolithophore genus Gephyrocapsa Kamptner and related Plio-Pleistocene chronostratigraphic problems. In Prell, W.L., Gardner, J.V., et al., Init. Repts. DSDP, 68: Washington (U.S. Govt. Printing Office), $325-343$.

Rio, D., Backman, J., Raffi, I., in press. Calcareous nannofossil biochronology and the Pliocene/Pleistocene boundary: the Neogene/Quaternary boundary. Final Rep. IGCP Project, 41.

Rio, D., Fornaciari, E., and Raffi, I., 1990a. Late Oligocene through early Pleistocene calcareous nannofossils from western equatorial Indian Ocean (Leg 115). In Duncan, R.A., Backman, J., Peterson, L.C., et al., Proc. ODP, Sci. Results, 115: College Station, TX (Ocean Drilling Program), 175-235.

Rio, D., Raffi, I., and Villa, G., 1990b. Pliocene-Pleistocene calcareous nannofossil distribution patterns in the Western Mediterranean. In Kastens, K.A., Mascle, J., et al., Proc. ODP, Sci. Results, 107: College Station, TX (Ocean Drilling Program), 513-533.

Rio, D., Sprovieri, R., and Di Stefano, E., 1994. The Gelasian stage: a proposal of a new chronostratigraphic unit of the Pliocene series. Riv. It. Paleontol. Strat., 100:103-124.

Rio, D., Sprovieri, R., and Fornaciari, E., 1990. Remarks on the middle/late Miocene boundary. IX R.C.M.N.S. Congr., Barcelona, Abstr. Volume, 283.

Rio, D., Sprovieri, R., and Thunell, R., 1991. Pliocene-lower Pleistocene chronostratigraphy: a re-evaluation of Mediterranean type sections. Geol. Soc. Am. Bull., 103:1049-1058.

Roth, P.H., 1974. Calcareous nannofossils from the northwestern Indian Ocean, Leg 24, Deep Sea Drilling Project. In Fisher, R.L., Bunce, E.T., et al., Init. Repts. DSDP, 24: Washington (U.S. Govt. Printing Office), 969-994.

, 1983. Jurassic and Lower Cretaceous calcareous nannofossils in the western North Atlantic (Site 534): biostratigraphy, preservation, and some observations on biogeography and paleoceanography. In Sheridan, R.E., Gradstein, F.M., et al., Init. Repts. DSDP, 76: Washington (U.S. Govt. Printing Office), 587-621.

Roth, P.H., and Thierstein, H., 1972. Calcarcous nannoplankton: Leg 14 of the Deep Sea Drilling Project. In Hayes, D.E., Pimm, A.C., et al., Init. Repts. DSDP, 14: Washington (U.S. Govt. Printing Office), 421-485.

Takayama, T., 1970. The Pliocene-Pleistocene boundary in the Lamont Core V-21-98 and at Le Castella, Southern Italy. J. Mar. Geol., 6:70-77.

Takayama, T., and Sato, T., 1987. Coccolith biostratigraphy of the North Atlantic Ocean, Deep Sea Drilling Project Leg 94. In Ruddiman, W.F., Kidd, R.B., Thomas, E., et al., Init. Repts. DSDP, 94 (Pt. 2): Washington (U.S. Govt. Printing Office), 651-702.

Tauxe, L., Opdyke, N.D., Pasini, G., and Elmi, C., 1983. The paleomagnetism of the Vrica section (Calabria, Italy): the proposed Pliocene/Pleistocene Boundary-stratotype section. Nature, 304:125-129.

Thierstein, H.R., Geitzenauer, K., Molfino, B., and Shackleton, N.J., 1977. Global synchroneity of late Quaternary coccolith datum levels: validation by oxygen isotopes. Geology, 5:400-404.

Young, J.R., 1990. Size variation of Neogene Reticulofenestra coccoliths from Indian Ocean DSDP Cores. J. Micropaleontol., 9:71-85.

Zijderveld, J.D.A., Zachariasse, J.W., Verhallen, P.J.J.M., and Hilgen, F.J., 1986. The age of the Miocene-Pliocene boundary. Newsl. Stratigr., $16: 169-181$.

Date of initial receipt: 12 April 1993

Date of acceptance: 31 December 1993

Ms 138SR-112 


\section{APPENDIX A}

\section{Calcareous Nannofossils Considered in This Chapter} (in Alphabetic Order of Generic Epithets)

Amaurolithus amplificus (Bukry and Percival, 1971) Gartner and Bukry, 1975 Amaurolithus delicatus Gartner and Bukry, 1975

Amaurolithus primus (Bukry and Percival, 1971) Gartner and Bukry, 1975

Amaurolithus tricorniculatus (Gartner, 1967) Gartner and Bukry, 1975

Calcidiscus leptoporus (Murray and Blackman, 1898) Loeblich and Tappan, 1978

Calcidiscus macintyrei (Bukry and Bramlette, 1969) Loeblich and Tappan, 1978

Calcidiscus premacintyrei Theodoridis, 1984

Catinaster calyculus Martini and Bramlette, 1963

Catinaster coalitus Martini and Bramlette, 1965

Ceratolithus acutus Gartner and Bukry, 1974

Ceratolithus armatus Müller, 1974

Ceratolithus cristatus Kamptner, 1950

Ceratolithus rugosus Bukry and Bramlette, 1968

Ceratolithus telesmus Norris, 1965

Coccolithus miopelagicus Bukry, 1971

Coccolithus pelagicus (Wallich, 1877) Schiller, 1930

Coccolithus radiatus Kamptner, 1955

Coronocyclus nitescens (Kamptner, 1963) Bramlette and Wilcoxon, 1967

Cyclicargolithus floridanus (Roth and Hay in Hay et al., 1967) Bukry, 1971

Discoaster adamanteus Bramlette and Wilcoxon, 1967

Discoaster asymmetricus Gartner, 1969

Discoaster aulakos Gartner, 1967

Discoaster bellus Bukry and Percival, 1971

Discoaster berggrenii Bukry, 1971

Discoaster blackstockae Bukry, 1973

Discoaster bollii Martini and Bramlette, 1963

Discoaster braarudii Bukry, 1971

Discoaster brouweri Tan (1927) emend. Bramlette and Riedel, 1954

Discoaster calcaris Gartner, 1967

Discoaster challengeri Bramlette and Riedel, 1954

Discoaster decorus (Bukry, 1971) Bukry, 1973

Discoaster deflandrei Bramlette and Riedel, 1954

Discoaster exilis Martini and Bramlette, 1963

Discoaster hamatus Martini and Bramlette, 1963

Discoaster icarus Stradner, 1973

Discoaster intercalaris Bukry, 1971

Discoaster kugleri Martini and Bramlette, 1963

Discoaster loeblichii Bukry, 1971

Discoaster misconceptus Theodoridis, $1984=$ Discoaster pentaradiatus

Discoaster moorei Bukry, 1971

Discoaster musicus Stradner, 1959

Discoaster neohamatus Bukry and Bramlette, 1969

Discoaster neorectus Bukry, 1971

Discoaster pansus (Bukry and Percival, 1971) Bukry, 1973

Discoaster pentaradiatus Tan (1927) emend. Bramlette and Riedel, 1954

Discoaster perclarus Haq in Haq et al., 1967

Discoaster prepentaradiatus Bukry and Percival, 1971

Discoaster pseudovariabilis Martini and Worsley, 1971

Discoaster quinqueramus Gartner, 1969

Discoaster sanmiguelensis Bukry, 1981 = Discoaster musicus

Discoaster signus Bukry, 1971

Discoaster subsurculus Gartner, 1967

Discoaster surculus Martini and Bramlette, 1963

Discoaster tamalis Kamptner, 1967

Discoaster triradiatus Tan, 1927

Discoaster tristellifer Bukry, 1976

Discoaster tuberi Filewicz, 1984

Discoaster variabilis Martini and Bramlette, 1963

Geminilithella rotula (Kamptner, 1956) Backman, 1980

Gephyrocapsa oceanica Kamptner, 1943
Gephyrocapsa omega Bukry, 1973

Gephyrocapsa parallela Hay and Beaudry, 1973

Helicosphaera ampliaperta Bramlette and Wilcoxon, 1967

Helicosphaera carteri (Wallich, 1877) Kamptner, 1954

Helicosphaera carteri var. wallichii (Lohmann) Theodoridis, 1984

Helicosphaera hyalina Gaarder, 1970

Helicosphaera intermedia Martini, 1965

Helicosphaera sellii Bukry and Bramlette, 1969

Minylitha convallis Bukry, 1973

Orthorhabdus serratus Bramlette and Wilcoxon, 1967 = Triquetrorabdulus serratus

Pseudoemiliania lacunosa (Kamptner, 1963) Gartner, 1969

Reticulofenestra haqii Backman, 1978

Reticulofenestra minuta Roth, 1970

Reticulofenestra minutula (Gartner, 1967) Haq and Berggren, 1978

Reticulofenestra pseudoumbilicus (Gartner, 1967) Gartner, 1969

Sphenolithus abies Deflandre in Deflandre and Fert, 1954

Sphenolithus heteromorphus Deflandre, 1953

Sphenolithus moriformis (Brönnimann and Stradner, 1960) Bramlette and Wilcoxon, 1967

Sphenolithus neoabies Bukry and Bramlette, 1969

Triquetrorhabdulus extensus Theodoridis, 1984

Triquetrorhabdulus farnsworthii (Gartner, 1967) Perch-Nielsen, $1985=$ Triquetrorhabdulus rugosus

Triquetrorhabdulus milowii Bukry, 1971

Triquetrorhabdulus rioensis Olafsson, 1989

Triquetrorhabdulus rugosus Bramlette and Wilcoxon, 1967

Triquetrorhabdulus serratus (Bramlette and Wilcoxon, 1967) Olafsson, 1989

\section{APPENDIX B}

Definition, Occurrence, and Remarks for the Three Biostratigraphic Units That Divide Okada and Bukry (1980) Subzone CN9b

CN9bA. Amaurolithus primus Subzone

Definition: Top - lowest occurrence of Amaurolithus amplificus; bottom - lowest occurrence of A. primus.

Occurrence: The type locality is Hole 853B from Sample 138-853B-7H-2, $147 \mathrm{~cm}$, to $-6 \mathrm{H}-4,65 \mathrm{~cm}$. Other occurrences are recorded at Leg 138 Sites 844 , $845,846,848,849,850,851$, and 852 , and at Leg 115 Sites 707, 709, 710, 711, and 713 .

\section{CN9bB. Amaurolithus amplificus Subzone}

Definition: Top - highest occurrence of A. amplificus; bottom - lowest occurrence of $A$. amplificus.

Remarks: Bergen (1984) indicated that A. amplificus became extinct within the upper part of $\mathrm{CN} 9 \mathrm{~b}$ in sediments from the tropical Atlantic Ocean. Similar distribution range for A. amplificus has been observed by Rio et al. (1990a) in the equatorial Indian Ocean, where it was calibrated to the polarity time scale and corresponded to Chron $3 \mathrm{An}$. This same stratigraphic position for A. amplificus is recorded in the eastern equatorial Pacific.

Occurrence: The type locality is Hole 853B from Sample 138-853B-6H-4, $27 \mathrm{~cm}$, to $-5 \mathrm{H}-5,120 \mathrm{~cm}$. Other occurrences are recorded at Leg 138 Sites 844 , $846,848,849,850,851$, and 852 , and at Leg 115 Sites $707,709,710,711$, and 713.

\section{CN9bC. Amaurolithus delicatus Subzone}

Definition: Top - highest occurrence of Discoaster quinqueramus; bottom - highest occurrence of A. amplificus.

Occurrence: The type locality is Hole 852B from Sample 138-852B-7H$\mathrm{CC}$ to $-7 \mathrm{H}-3,140 \mathrm{~cm}$. Other occurrences are recorded at Leg 138 Sites 844 , $846,848,849,850,851$, and 853 , and at Leg 115 Sites 707, 709, 710, 711, and 713 . 


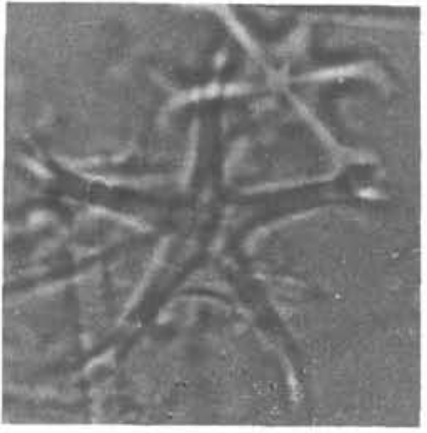

1

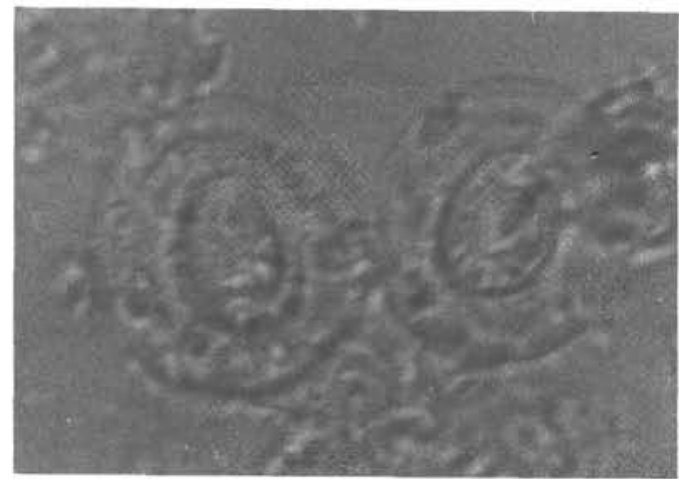

$6 a$

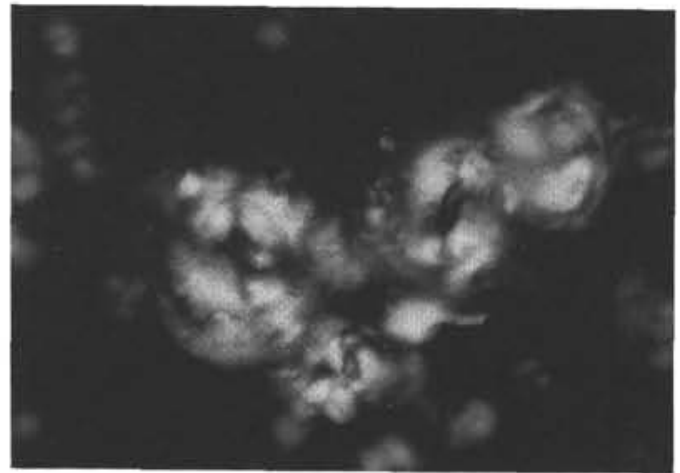

$6 b$

Plate 1. 1. Discoaster hamatus Martini and Bramlette; $\times 2000$. Sample $138-845 \mathrm{~A}-15 \mathrm{H}-5,149 \mathrm{~cm}$; parallel light. 2. Discoaster calcaris Gartner; $\times 2000$. Sample 138-845A-16H-1, $120 \mathrm{~cm}$; parallel light. 3-5. Discoaster kugleri Martini and Bramlette; $\times 2000$. Sample 138-846B$35 \mathrm{X}-3,120 \mathrm{~cm}$; parallel light. 6. Coccolithus miopelagicus Bukry; $\times 2000$. Sample $138-846 \mathrm{~B}-35 \mathrm{X}-3,120 \mathrm{~cm}$; (a) parallel light; (b) crossed nicols. 7. Acme in abundance of Sphenolithus heteromorphus Deflandre; $\times 1400$. Sample 138-845A-31X-CC; crossed nicols.

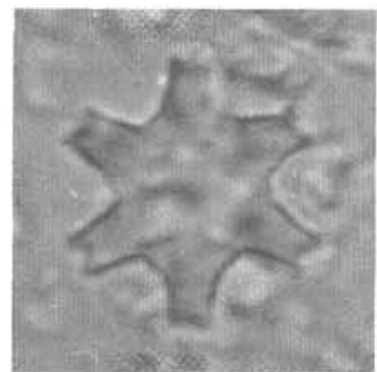

3

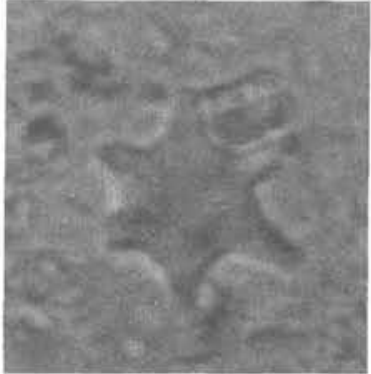

7
4

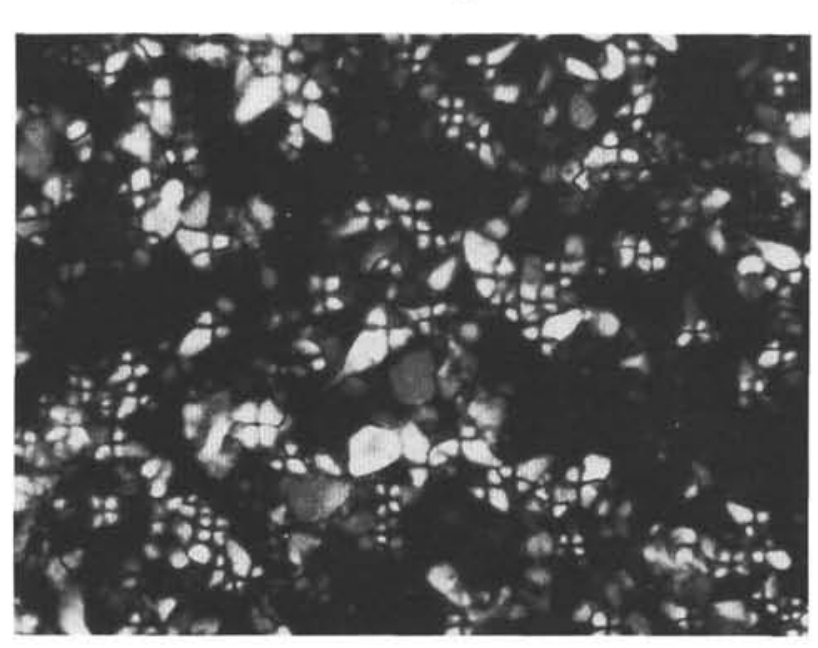

\section{5}




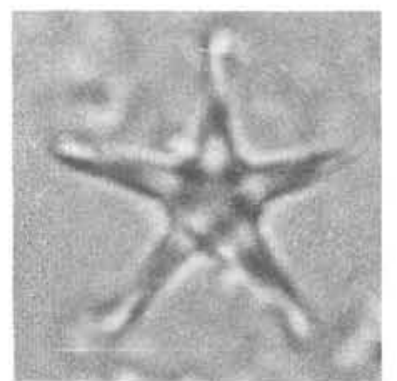

1

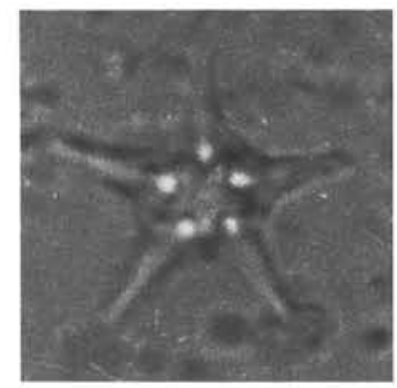

2

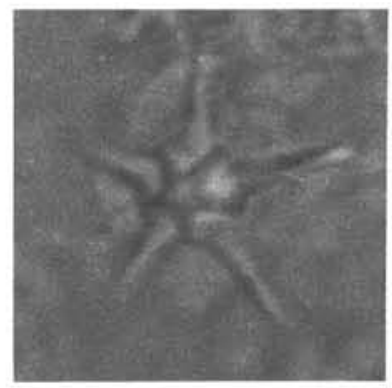

3

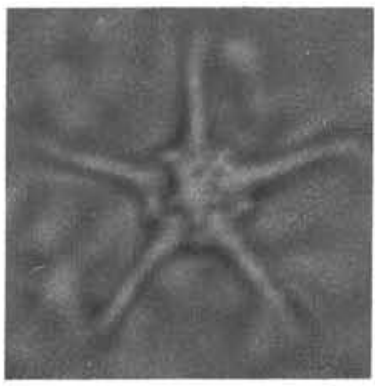

4

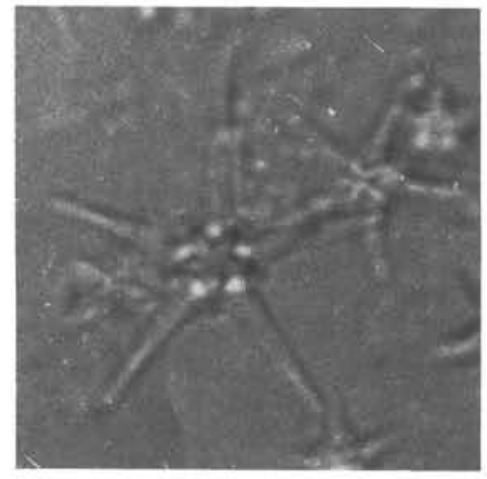

5

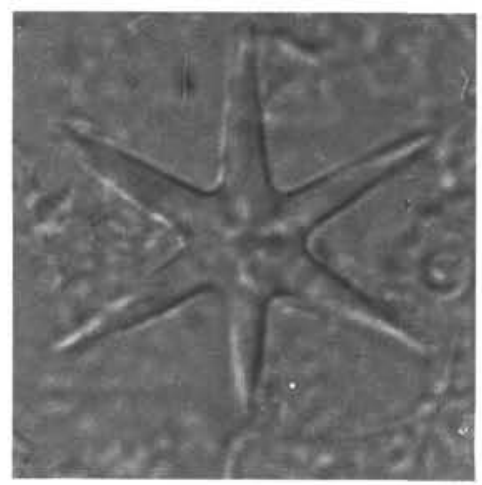

8

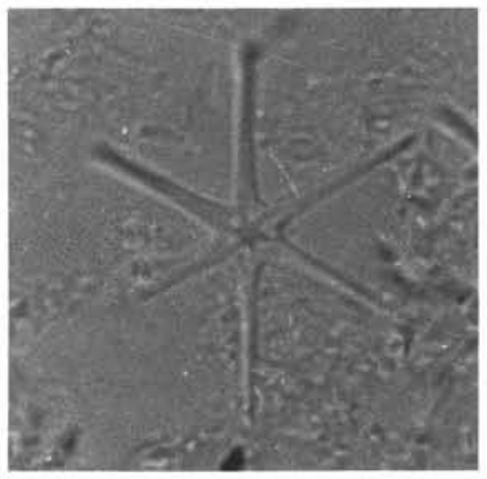

6

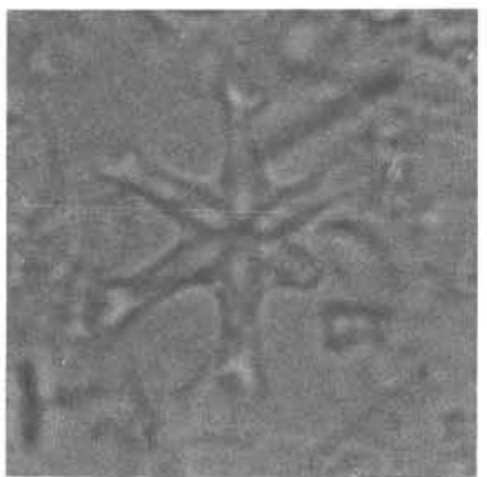

9

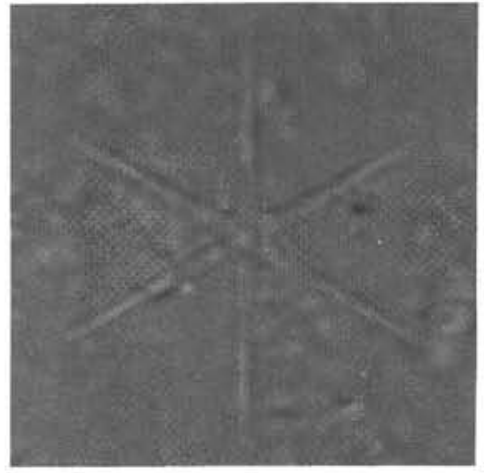

7

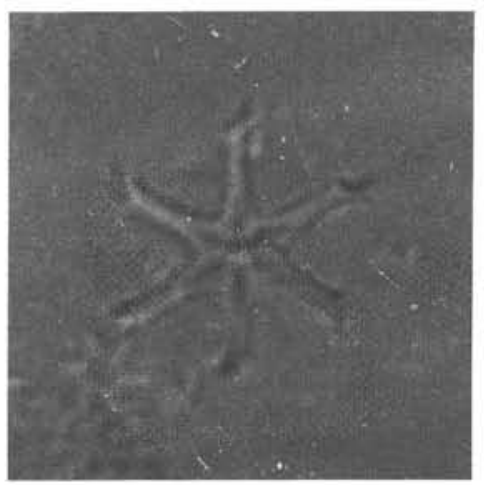

10

Plate 2. All specimens at parallel light. 1. Discoaster berggrenii Bukry (primitive form); $\times 2000$. Sample 138-853D-7H-4, $60 \mathrm{~cm}$. 2. Discoaster berggrenii Bukry; $\times 2400$. Sample 138-844B-5H-2, $29 \mathrm{~cm}$. 3. Discoaster berggrenii-Discoaster quinqueramus intergrade; $\times 2000$. Sample 138-853D$7 \mathrm{H}-1,30 \mathrm{~cm}$. 4. Discoaster quinqueramus Gartner; $\times 2000$. Sample 138-853D-7H-1,30 cm. 5. Discoaster quinqueramus Gartner (left) and Discoaster sp. 1 (right); $\times 2000$. Sample 138-853B-6H-3, 65 cm. 6, 7. Discoaster sp. $2 ; \times 2000 ;$ (6) Sample 138-853B-7H-2, 147 cm; (7) Sample 138-853D-7H-1, $30 \mathrm{~cm}$. 8. Discoaster neorectus Bukry; $\times 2000$. Sample 138-853D-7H-1, $30 \mathrm{~cm}$. 9, 10. Discoaster loeblichii Bukry; $\times 2000 ;(9)$ Sample 138-846B$30 \mathrm{X}-2,60 \mathrm{~cm}$; (10) Sample 138-853B-7H-4, $30 \mathrm{~cm}$. 


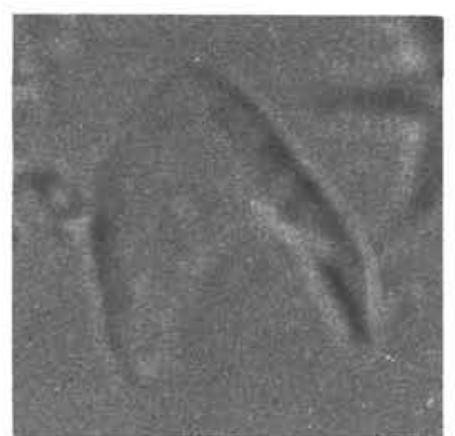

1

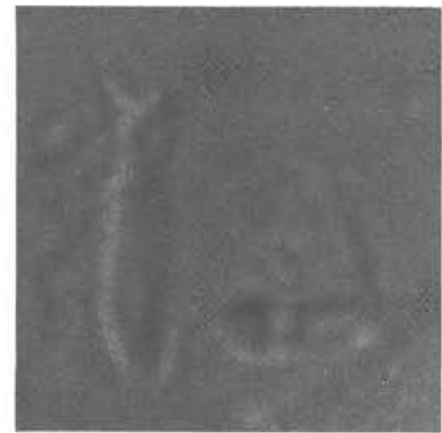

4

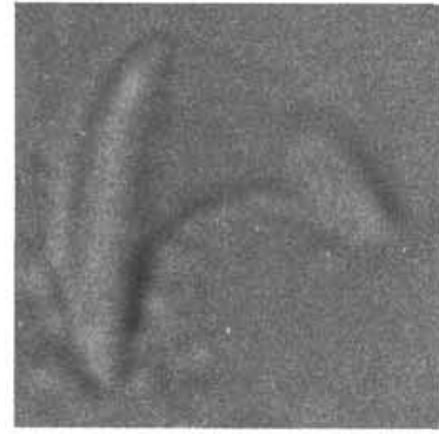

7

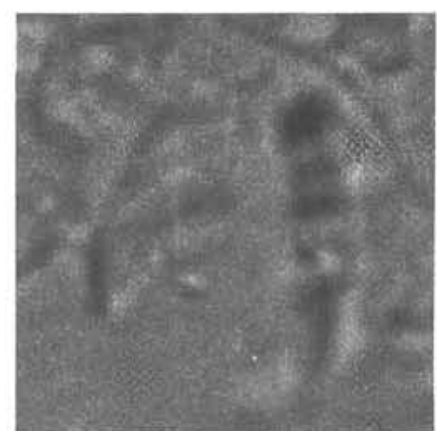

2

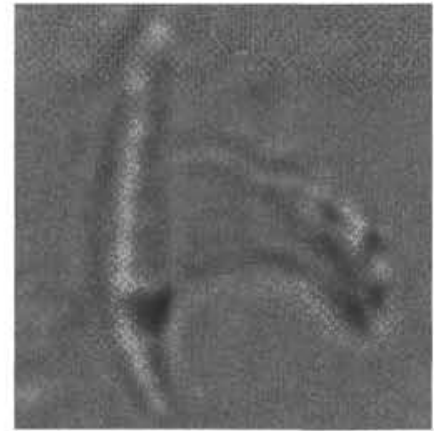

5

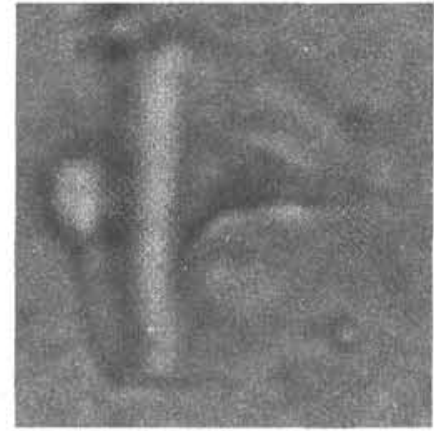

8

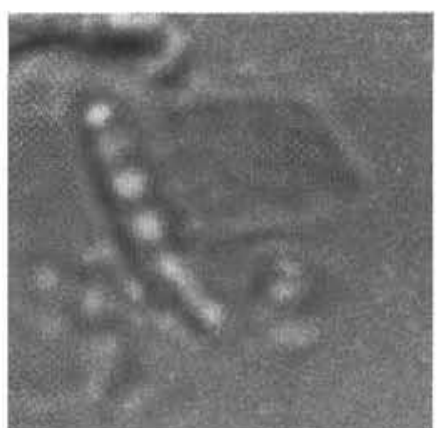

3

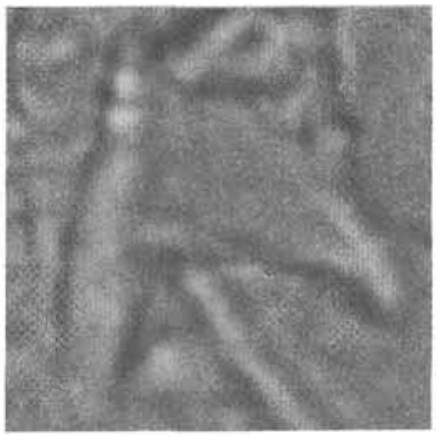

6

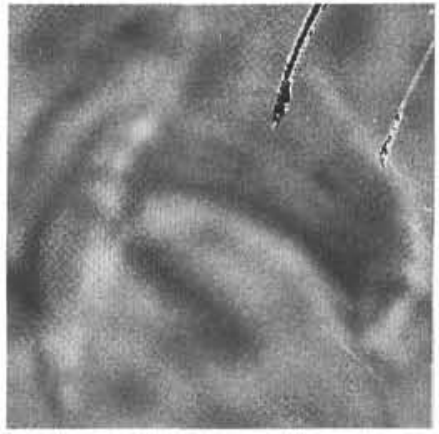

9

Plate 3. All specimens $\times 4000$, parallel light. 1, 2, 5. Amaurolithus primus (Bukry and Percival); $(1,2)$ Sample $138-853 \mathrm{~B}-7 \mathrm{H}-3,30 \mathrm{~cm}$; (5) Sample 138-853B-7H-2, $147 \mathrm{~cm} . \quad 3,4,6$. Triquetrorhabdulus-Amaurolithus intergrade. Sample 138-853B-7H-2, $147 \mathrm{~cm} . \quad 7,8$. Triquetrorhabdulus extensus-Amaurolithus amplificus intergrade; (7) Sample 138-853B-6H-4, 27 cm; (8) Sample 138-844B-5H-2, 129 $\mathrm{cm}$. 9. Amaurolithus amplificus (Bukry and Percival). Sample 138-844B-5H-2, $129 \mathrm{~cm}$. 


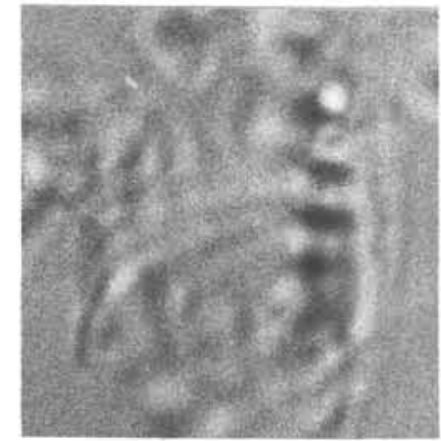

1

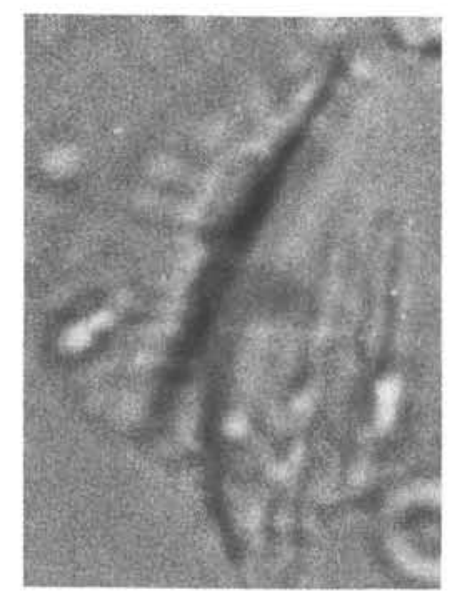

4

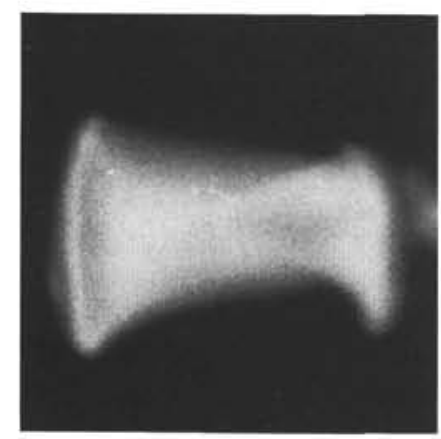

$6 a$

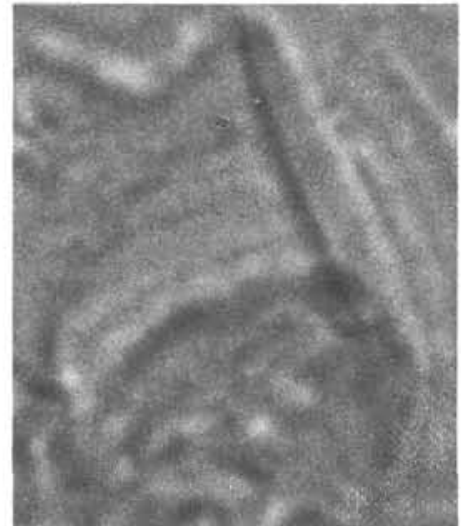

2

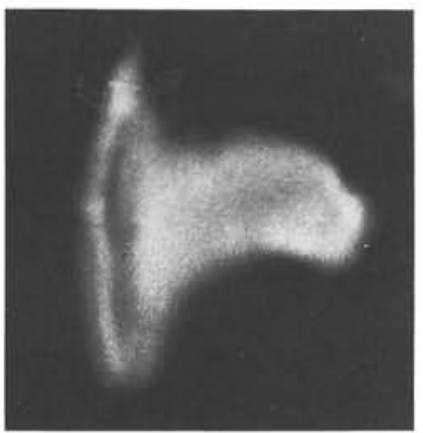

$5 a$

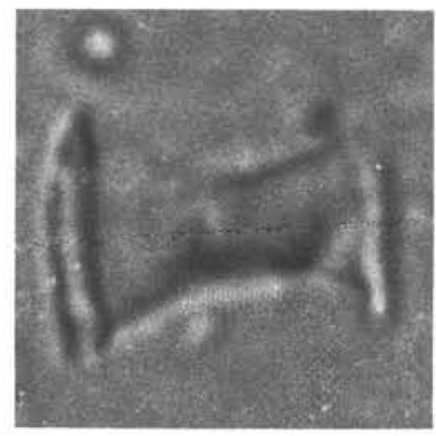

$6 b$

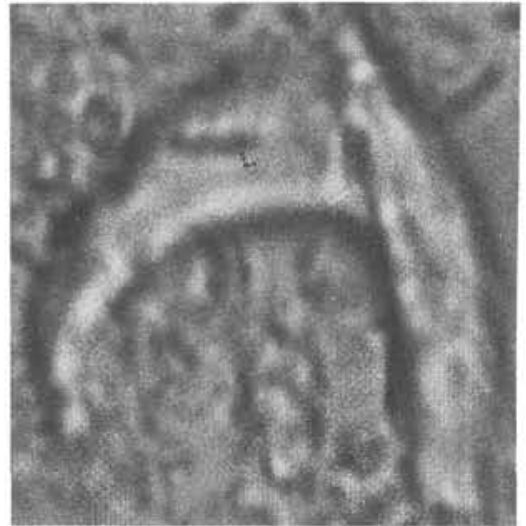

3

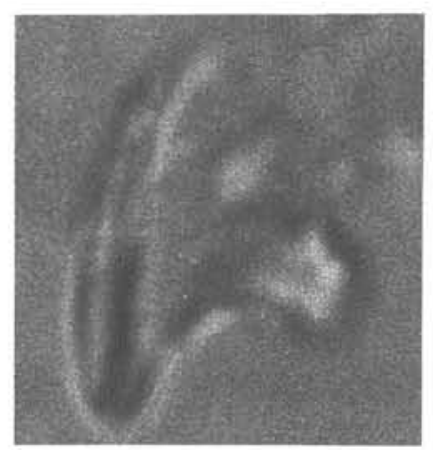

$5 b$

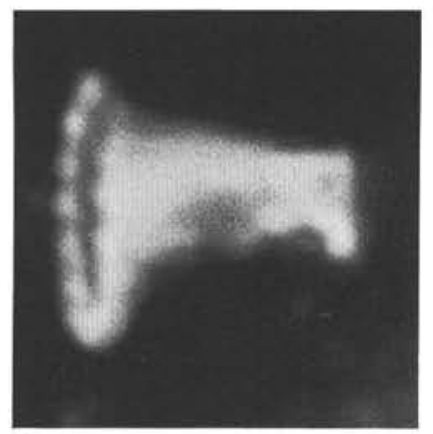

7

Plate 4. 1. Amaurolithus primus (Bukry and Percival); $\times 4000$. Sample 138-853B-7H-2, $147 \mathrm{~cm}$; parallel light. 2. Triquetrorhabdulus extensusAmaurolithus amplificus intergrade; $\times 4000$. Sample 138-853B-6H-4, $65 \mathrm{~cm}$; parallel light. 3. Amaurolithus amplificus (Bukry and Percival). Sample 138-853B-5H-6, $25 \mathrm{~cm}$; parallel light. 4. Triquetrorhabdulus extensus Theodoridis; $\times 4000$, lateral view. Sample $138-844 \mathrm{C}-4 \mathrm{H}-1,50 \mathrm{~cm}$. 5-7. Ceratolithus(?); (5) Sample 138-845B-15H-2, $145 \mathrm{~cm}$; (6,7) Sample 138-845B-15H-2, $100 \mathrm{~cm}$; (5a, 6a, 7) crossed nicols; (5b, 6b) parallel light. 